Renata Adriana Garbossa Silva

\title{
Organizadora
}

\section{GEOCIÊNCIAS CONJUNTURA E DEBATE}

\section{VOLUME 1: COVID-19}

Editora Dialética e Realidade Curitiba - PR

\section{1}


Os livros do selo Dialética e Realidade apresentam resultados de pesquisas desenvolvidas por professores e pesquisadores em formato eletrônico com licenciamento ( $\mathrm{CC}$ BY $+\mathrm{NC}$ ). A proposta de tratamento dialético busca estabelecer a verdade por meio de argumentos que esclareçam aspectos de interesse para a comunidade acadêmica e para a sociedade de forma geral.

\begin{tabular}{|ll}
\hline Dados Comerciais \\
\hline Rua & Alberto Rutz 491 - Casa 4 \\
Cidade & Curitiba \\
Bairro & Portão \\
CEP & 81320280 \\
Site & http://dialeticaerealidade.com \\
E-mail & dialeticaerealidade@gmail.com
\end{tabular}

Editora chefe Prof. ${ }^{a}$ Dr. ${ }^{a}$ Dinamara Pereira Machado

Responsável técnico Prof. Dr. Antonio Siemsen Munhoz

Aprendiz técnica Fabíola Ribeiro Vieira

\section{Conselho Editorial Nacional}

Prof. $\quad$ Dr. Adriano Souza Lima

Prof. Dr. André Luiz Cavazzani Moskaleski

Prof. Dr. Antonio Siemsen Munhoz

Prof. ${ }^{a} \quad$ Dr. ${ }^{a}$ Andréia Furtado

Prof. Me. Armando Kolbe Júnior

Prof. Dr. Cícero Manoel Bezerra

Prof. ${ }^{a} \quad$ Dr. ${ }^{a}$ Deisily de Quadros

Prof. ${ }^{a} \quad$ Dr. ${ }^{a}$ Dinamara Pereira Machado

Prof. Me. Edvaldo Luiz Rando Junior

Prof. ${ }^{a} \quad$ Dr. ${ }^{a}$ Flávia Brito Dias

Prof. Dr. Guilherme Augusto Pianezzer

Prof. ${ }^{a} \quad$ Dr. ${ }^{a}$ Gisele do Rocio Cordeiro

Prof. ${ }^{a} \quad$ Dr. ${ }^{a}$ Katiuscia Mello Figuerôa

Prof. Dr. Luis Fernando Lopes 


\begin{tabular}{|c|c|}
\hline Prof. ${ }^{a}$. & Dr. ${ }^{a}$ Leociléa Aparecida Vieira \\
\hline Prof. & Dr. Marcos Ruiz da Silva \\
\hline Prof. ${ }^{a}$ & Esp. Maria Teresa Xavier Cordeiro \\
\hline Prof. & Dr. ${ }^{a}$ Marilene Garcia \\
\hline Prof. ${ }^{a}$ & Dr. ${ }^{a}$ Márcia Regina Mocelin \\
\hline Prof. ${ }^{a}$ & Dr. ${ }^{a}$ Naura Garcia Carapeto Ferreira \\
\hline Prof. & Me. Paulo Martinelli \\
\hline Prof. & Dr. Rafael Pereira Dubiela \\
\hline Prof. ${ }^{a}$ & Dr. ${ }^{a}$ Roberta Ravaglio Gagno \\
\hline Prof. ${ }^{a}$ & Dr. ${ }^{\text {a }}$ Renata Adriana Garbossa Silva \\
\hline Prof. ${ }^{a}$ & Me. Renata Burgo Fedato \\
\hline Prof. ${ }^{a}$ & Dr. ${ }^{a}$ Tatiane Calve \\
\hline Prof. ${ }^{a}$ & Me. Thiana Maria Becker \\
\hline Prof.a & Dr. ${ }^{a}$ Tatiane Calve \\
\hline
\end{tabular}

\section{Conselho Editorial Internacional}

Prof. Dr. Santiago Castillo Arredondo

Prof. ${ }^{a} \quad$ Dr. ${ }^{a}$ Maria Esther Martinez Quinteiro

O projeto publicação acadêmica reúne um grupo de pesquisadores especializados e independentes provenientes de diferentes IES em nível global. Ele está desenhado com a integração de diversas áreas do conhecimento. Seu objetivo é a abertura de um canal de comunicação utilizado para divulgação de estudos e pesquisas acadêmicas. A participação não resulta em remuneração financeira de nenhuma espécie. Os únicos recursos financeiros envolvidos são aqueles devidos ao registro do ISBN, do código de barras e da ficha catalográfica. Custos administrativos poderão ser rateados entre os participantes. Os textos publicados são de total responsabilidade de seus autores.

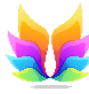

Editora Dialética e Realidade 
Esta obra está sendo entregue aos leitores na modalidade creative commons licenciada de acordo com os seguintes termos cc by+nc. Esta indicação permite que a obra seja utilizada de forma livre, referenciando o autor e não utilizando o material com finalidades comerciais.

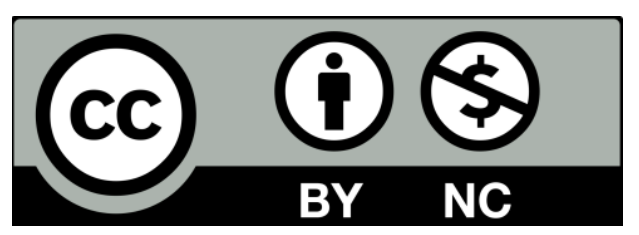

\section{FICHA CATALOGRÁFICA} Dados Internacionais de Catalogação na Publicação (CIP)
(Câmara Brasileira do Livro, SP, Brasil)

Geociências : conjuntura e debate [livro eletrônico] : volume I : Covid 19/Renata Adriana Garbossa Silva (organizadora). -- Curitiba : Editora Dialética e Realidade, 2021. PDE

Vários autores.

Bibliografia.

ISBN $978-65-87217-32-1$

1. Coronavirus (COVID-19) - Pandemia 2. Educação 3. Geociências 4. Geociências - Estudo e ensino 5. Metodologia 6. Prática de ensino 7. Professores Formaçăo I. Silva, Renata Adriana Garbossa.

Índices para catálogo sistemático:

1. Geociências : Formaçăo : Educaçăo 370.71

Cibele Maria Dias - Bibliotecária - CRB-8/9427 


\section{REFERÊNCIA BÁSICA}

SILVA, Renata Adriana Garbossa (Organizadora). Geociências conteúdo e debate: vol I: covid 19. Curitiba: Editora Dialética e Realidade, 2021.

Há cartas de concordância com esta publicação, de acordo com posicionamento de todos os autores, como guardados em arquivos do sistema.

A correção do texto, com relação aos elementos componentes foi desenvolvida pelo autor de cada capítulo. 


\section{GEOCIÊNCIA CONJUNTURA E DEBATE}

VOLUME I COVID 19

Editora Dialética e Realidade Curitiba

2021 
RENATA ADRIANA GARBOSSA SILVA

(Organizadora)

\section{GEOCIÊNCIA CONJUNTURA E DEBATE VOLUME I COVID 19}

Editora Dialética e Realidade Curitiba

2021 


\section{PREFÁCIO}

\section{PARA OS TEMPOS DIFÍCEIS}

Parece que os "tempos difíceis para os sonhadores e sonhadoras" são perenes. Tempos difíceis marcam a escrita deste prefácio. As incertezas e um horizonte de mudanças parecem cada vez mais distantes. A pluralidade de temas desta coletânea revela um lado fundamental do debate sobre a pandemia da Covid-19: esse desafio afetou muitos lados.

A análise da conjuntura, quando se está "no olho do furacão", parece ainda mais complexa, porque cada dia é um dia. No entanto, é possível construir uma reflexão atenta à pluralidade do que afeta e foi afetado no contexto pandêmico, a partir de uma leitura sensível sobre essas mudanças.

A partir dessa leitura sensível, que tem me acompanhado há alguns anos no âmbito das geografias emocionais, são notáveis os elementos que conectam essas múltiplas experiências. Um deles é a relevância do coletivo para pensar o espaço, o contexto escolar, a justiça social/espacial, as dinâmicas socioeconômicas e a natureza.

Nas experiências apresentadas, pensar as pessoas e suas dinâmicas participativas, inovativas, integrativas, mobilizadoras, reparadoras e equalizadoras é fundamental para enfrentar esses tempos difíceis. Mais do que pensar em políticas públicas ou privadas para sanar os abissais problemas no/do contexto socioeconômico do Brasil e suas escalas de relações, é preciso provocar nossa leitura sensível para entender o protagonismo das pessoas em decidir, lutar e brigar pelo rumo de suas vidas. 
Obviamente, tal declaração não quer dizer que não pauto a relevância dessas políticas, mas convido você, leitora e leitor desta obra, a provocar suas reflexões sobre a vida e as experiências pandêmicas a partir de uma leitura sensível sobre a realidade. Encontraremos muitas coisas que são colocadas para debaixo do tapete na/da ciência. Uma delas é a experiência emocional de milhões de pessoas que foram afetadas pela Covid-19. Medo, descaso, ansiedade, angústia, tristeza, raiva marcam, por um lado, o que temos vivido diariamente, pensando a experiência em nosso país, especialmente com os inúmeros absurdos na dinâmica do planejamento e gestão da pandemia, desde o seu início. Esperança, alívio, felicidade marcam, por outro lado, essa mesma dinâmica pandêmica, pensando o contexto daquelas pessoas que conseguiram/conseguem vencer todos os dias a doença.

O que quero provocar aqui, neste início de caminhada por esta coletânea, é que a percepção sensível sobre o que temos vivido nos entrega questões fundamentais sobre a intersubjetividade nas relações humanas, intersubjetividade que é sustentada também pelas experiências emocionais. Uma leitura sensível sobre a mediação das emoções em nossas experiências intersubjetivas possibilita, a partir da Geografia, entender a organização, utilização, planejamento dos espaços e das espacialidades, não só em termos socioeconômicos, por exemplo, mas também emocionais.

Isso a que tenho chamado geografia sensível, que tem me acompanhado nos debates no campo das geografias emocionais, privilegia as subjetividades presentes nas vivências espaciais. É por isso que faço o convite para que, ao se lançar à dimensão sensível nas (entre)linhas desta coletânea, possa perceber que elementos em comum entrelaçam e sustentam os fios das narrativas aqui apresentadas.

Destaco que isso não é tarefa fácil, mas é cada vez mais fundamental. O que temos visto, mais do que nunca, é a fragilidade emocional que a pandemia escancarou; foi preciso, do dia para a noite, parar de abraçar, beijar e tocar as 
pessoas que amamos e com quem convivemos cotidianamente, no espaço público, no trabalho, na escola... Isso nos revela que o conteúdo emocional é parte integrante da totalidade humana e é aquilo que nos une e une também distintas escalas geográficas, sociais, econômicas, políticas, culturais. "Estamos no mesmo mar, mas não estamos no mesmo barco", é o que uma reflexão mais crítica tem pautado, algo com que concordo profundamente. Mas, fazendo outro uso dessa crítica, entendo que o mar pode ser interpretado como a nossa experiência emocional nesse contexto: profunda, com seus momentos de calmaria e turbilhão, aparentemente sem um horizonte, mas em busca da terra firme.

Assim, entendo que a condição humana de sentir emoções e poder experienciá-las na sua relação com os lugares possibilita mergulhar nessa esfera do sensível e pensar o espaço geográfico para além da sua condição material. Minha provocação é que você adentre nesta coletânea refletindo sobre suas emoções nesse contexto, como se reconhece nas experiências aqui relatadas e como reconhece o outro e suas emoções expressas, por vezes, de forma não tão claras, mas certamente presentes.

Que as emoções possam ser a ponte que the faça percorrer esta obra. Que elas possam ser o fio que conecta as experiências aqui relatadas. Que sejam a força para as mobilizações coletivas. Que possam ser o motor de real transformação da sociedade.

Esteja atenta e atento às suas emoções. A Geografia precisa disso. O contexto pandêmico pede isso.

Boa leitura!

Profa. Dra. Marcia Alves Soares da Silva Terras cuiabanas, agosto de 2021. 


\section{APRESENTAÇÃO}

No final do ano de 2019 a Organização Mundial de Saúde (OMS) foi alertada que casos de pneumonia foram identificados na República Popular da China sendo um tipo de coronavírus que ainda não havia sido identificado em seres humanos. Um mês depois a OMS caracterizou o surto como Emergência de Saúde Pública de Importância Internacional (ESPII) ${ }^{1}$, definido como uma pandemia.

Em âmbito global, a dinâmica da paisagem noturna foi alterada a partir do confinamento compulsório imposto pela pandemia. Nas vilas e cidades houve alterações na utilização da iluminação artificial das ruas e avenidas, das áreas residenciais, prédios e espaços comerciais, dos edifícios públicos e privados com impactos em escalas significativas da poluição luminosa. No Brasil, o aumento do número de casos que se espalhou por todo o território, fez com que uma série de medidas e estratégias, mesmo que incipientes, fossem adotadas estabelecendo normas excepcionais em praticamente todos os setores. No campo da definição sobre a aplicação dos recursos públicos, havia expectativas, de que via on-line, houvesse uma maior participação da população na escolha das prioridades dos gastos governamentais.

De acordo com a Organização Mundial da Saúde (OMS), o coronavírus foi identificado pela primeira vez na cidade de Wuhan (China), em 31 de dezembro de 2019, e desde então, vem buscando através de parcerias governamentais ampliar os conhecimentos científicos e formas de combatê-lo em todo o mundo. Porém, os objetivos econômicos expansivos do capitalismo, que busca utilizar a natureza de forma utilitária e devastadora, provocam consequências sérias para

\footnotetext{
${ }^{1}$ É um evento extraordinário que pode constituir um risco de saúde pública para outros países devido à disseminação internacional de doenças; e potencialmente requer uma resposta internacional coordenada e imediata" (Organização Pan Americana de Saúde).
} 
que a vida continue existindo. Neste momento de incertezas, (re)pensar as cidades tem sido um dos grandes desafios para aqueles que pensam, planejam e constroem as cidades objetivando tornar os espaços públicos em conformidade com os hábitos, costumes e comportamentos diários das pessoas.

O primeiro caso diagnosticado de coronavírus no Brasil, foi em fevereiro de 2019 e desde então, as medidas adotadas para evitar a propagação do vírus, dentre as quais a de isolamento social, mesmo que temporariamente, acabaram por ampliar a crise econômica no país. Os desafios gerados pela Pandemia atingiram diferentes setores produtivos, associadas ao aumento do desemprego e redução do poder de consumo da população, ressentem de uma ampla estratégia de superação em um momento em que o país passa por uma instabilidade política.

No campo educacional, as instituições de ensino privadas e públicas em todos os níveis de ensino precisaram se (re)inventar e, sobretudo, os profissionais da educação se viram forçados a alterar a sua dinâmica diante do cenário vigente do ensino remoto, buscando se adaptar às novas formas de ensinar e aprender com a utilização de novas ferramentas tecnológicas, até então, não tão presentes na práxis educacional desses profissionais. As adaptações necessárias por parte dos professores nas suas rotinas de trabalho, somadas às dificuldades para transformarem seus lares em salas de aula e, os efeitos dessas mudanças sobre a vida desses professores, trazem à tona reflexões que precisam ser feitas.

Desta forma, o livro que você tem em mãos "Geociências Conjuntura e Debate VI: Covid 19" é produto de um grupo de professores e pesquisadores de diversas áreas do conhecimento que, através dos capítulos apresentados estabelecem um diálogo com o dia a dia do leitor, bem como, no campo de sua atuação objetivando, de alguma forma, gerar debates, reflexões e leituras sobre as transformações ocorridas a partir das dificuldades impostas pela pandemia do coronavírus. 
A obra Geociências: conjuntura e debate, inaugura uma coleção anual de títulos, que terá como eixo o campo temático da Geografia e das Ciências Biológicas. A combinação entre ambas surgiu da forma de organização e gestão dos cursos de licenciatura, bacharelado, formação pedagógica e segunda licenciatura em Geografia e Ciências Biológicas do Centro Universitário Internacional - Uninter.

Dessa opção de gestão, resultou a criação do campo de Geociências, inicialmente uma opção de organização, mas que ganha sua primeira contribuição escrita em forma de livro com a presente obra. Nesse primeiro volume, aceitamos as colaborações independentes dos professores da equipe e alguns convidados para compor o livro.

Portanto, a presente edição é, por um lado, marcada por esse primeiro movimento de produção escrita entre os professores e pesquisadores da rede de Geociências. Por outro, por se tratar de um ano único da história contemporânea, a edição foi caracterizada pelos impactos da pandemia do novo coronavírus.

Assim, a proposta de criação e elaboração da obra, surgiu da necessidade de estabelecer uma primeira aproximação escrita em torno do campo constitutivo da Geociências. Os artigos a seguir, buscam apresentar a contribuição das Ciências Biológicas e da Saúde, mas também às Ciências Humanas e Sociais, pois ambas são fundamentais para se pensar soluções e, produzir conhecimento por meio de uma perspectiva coletiva de pensar acerca das questões latentes que se fizeram tão presentes na sociedade mundial e brasileira.

Como ponto de partida para esta coleção, a presente obra foi dividida em duas linhas de trabalho, traduzidas em duas seções dentro do livro. A primeira, intitulada: Pandemia e Produção do Espaço, estruturada para temas próprios do trabalho e da pesquisa dos bacharéis em Geociências. A segunda, intitulada: 
Pandemia e ensino, orientada para o exercício permanente da docência. Ambas as seções inauguram as linhas de trabalho dessa área em formação, tal como aqui proposta.

Boa leitura!

Os autores 


\section{SUMÁRIO}

SEÇÃO 1 - PANDEMIA E PRODUÇÃO DE ESPAÇO

CAPÍTULO 1 - ESPAÇOS PÚBLICOS E O TURISMO EM TEMPOS DE PANDEMIA

FRANCIELE MARILIES STEVAM

RENATA ADRIANA GARBOSSA SILVA

CAPÍTULO 2 - A DISTRIBUIÇÃO DE VACINAS PARA COVID-19 E A ORDEM

INTERNACIONAL: UM ENSAIO TEÓRICO ENTRE A GEOGRAFIA E A ESCOLA INGLESA

DE RELAÇÕES INTERNACIONAIS

ANDRÉ FRANCISCO MATSUNO DA FROTA

VERA CRISTINA SCHELLER DOS S. ROCHA

CAPÍTULO 3 - A PARTICIPAÇÃO POPULAR POR MEIO DE MECANISMOS

DEMOCRÁTICOS DE JUSTIÇA ESPACIAL EM TEMPOS DE PANDEMIA

RODOLFO DOS SANTOS SILVA

CAPÍTULO 4 - DINÂMICAS SOCIOESPACIAIS DO EMPREGO E DO DESEMPREGO NO BRASIL NO CONTEXTO DA PANDEMIA DE COVID-19

ALCELI RIBEIRO ALVES

CAPÍTULO 5 - ASTRONOMIA EM TEMPOS DE PANDEMIA: ALGUNS EVENTOS

CELESTES

GERMANO BRUNO AFONSO

THAISA MARIA NADAL

SEÇÃO II - PANDEMIA E ENSINO 121

CAPÍTULO 6 - COMPOSTEIRA COMO SUBSÍDIO À ECOALFABETIZAÇÃO NO ENSINO DE GEOCIÊNCIAS: PROPOSTA METODOLÓGICA

LARISSA WARNAVIN

NICOLE GERALDINE DE PAULA MARQUES WITT

CAPÍTULO 7 - PRÁTICAS DE ENSINO: A ESCOLA, O PROFESSOR E O ESTUDANTE PÓS-PANDEMIA 
MARIA ENEIDA FANTIN VERA CRISTINA SCHELLER DOS SANTOS ROCHA NICOLE GERALDINE DE PAULA MARQUES WITT CAPÍTULO 8 - CONTRIBUIÇÕES DA EJA PARA CIDADANIA COMPETENTE

MARIA TEREZA XAVIER CORDEIRO CAPÍTULO 09 - PANDEMIA E SISTEMAS EDUCACIONAIS: UM OLHAR SOBRE A SAÚDE DO PROFESSOR

THAISA MARIA NADAL

THEODORO LUTEMBERG DE SOUZA CAPÍTULO 10 - A PANDEMIA DO NOVO CORONAVÍRUS: IMPACTOS NO TRABALHO DOCENTE E NA APRENDIZAGEM DOS ALUNOS

MARIA ENEIDA FANTIN

THEODORO LUTEMBERG DE SOUZA RENATA ADRIANA GARBOSSA SILVA 
SEÇÃO 1 - PANDEMIA E PRODUÇÃO DE ESPAÇO 


\section{CAPÍTULO 1 - ESPAÇOS PÚBLICOS E O TURISMO EM TEMPOS DE PANDEMIA}

Procuram-se: cidades vivas, seguras, sustentáveis e saudáveis (GEHL, 2013).

FRANCIELE MARILIES STEVAM2 RENATA ADRIANA GARBOSSA SILVA3

\section{INTRODUÇÃO}

O objetivo deste capítulo é apresentar ao leitor a concepção e a evolução do espaço público e elementos fundamentais para discutir o espaço público e urbano, como a vida social nas cidades, a exclusão e como as cidades funcionam, à luz de teóricos como Ascher (2001), La Valle (2005), Oliveira (2001), Arendt (2007), Habermas (1962), Carmona (2014), Gomes (2006), Jacobs (1961) Whyte (2001) Zeisel (2006), entre outros. Em outros termos, abordar a forma

2 Licenciada e bacharela em Geografia pela UFPR (2016). Bacharela em Turismo pela Universidade Positivo (2009). Especialista em Gestão de Projetos pela Universidade Positivo (2017). Tem experiência na área de geociências, com ênfase em geografia física e pedologia, assim como na área de cartografia voltada à análise ambiental e geoprocessamento. É docente nos cursos da Área de Geociências do Centro Universitário Internacional Uninter.

3 Bacharela e licenciada em Geografia pela Universidade Estadual do Oeste do Paraná (2000). Mestra em Geologia pela UFPR (2003). Doutora em Geografia: Produção do Espaço e da Cultura pela UFPR (2019). Licenciada em Pedagogia pelo Centro Universitário Internacional Uninter (2020). Possui experiência no Ensino Fundamental e Médio. É professora do ensino superior desde 2003. Atualmente, é coordenadora da Área de Geociências do Centro Universitário Internacional Uninter. 
de pensar os espaços públicos urbanos a partir do início do século XXI, com base na dimensão urbana, pois a forma como eles são pensados e planejados influencia seu comportamento e funcionamento.

Com a pandemia da Covid-19, o turismo nos espaços públicos, no caso brasileiro, sofreu inúmeras alterações e impactos, afetando diretamente os destinos cuja economia é mais dependente da atividade turística, pois uma das características intrínsecas ao turismo que o diferenciam, fundamentalmente, de outras atividades econômicas ou produtivas é o fato de ser, antes de qualquer coisa, uma prática social. Dessa forma, ao longo do texto serão apresentados ao leitor gráficos e dados estatísticos para melhor exemplificar as principais perdas do setor no ano de 2020.

\section{ESPAÇO PÚBLICO}

A cidade é dinâmica e está em constante mudança; como tal, revela-se indispensável um olhar atento e primoroso sobre a fase do processo de transformação que vivemos, mencionada por Ascher (1996) - a "terceira revolução urbana" -, cujas dinâmicas de transformação, sempre presentes, como a individualização, racionalização e diferenciação social, geram uma sociedade mais complexa que se reflete na cidade e, em especial, no seu espaço público.

Mas, afinal, o que vem a ser o espaço público? Para Gurza Lavalle (2005), nas duas últimas décadas, o "público" é uma das categorias das ciências sociais e da filosofia política mais utilizadas, embora sua definição seja tarefa árdua. Além disso, pondera que existe uma diversidade de campos semânticos, de problemas disciplinares e de ambiguidade inerente às suas diferentes expressões conceituais. Apresenta um mapa das dimensões constitutivas da configuração do espaço público no mundo moderno a partir da sistematização 
dos usos e mudanças semânticas do vocábulo "público", fazendo um resgate de aproximadamente seis séculos (XIV-XX), durante os quais as dimensões ganharam interpretações variadas, sugerindo eventuais mudanças, apresentando concomitantemente a grande quantidade de terminologias existentes, como se fossem fenômenos distintos: vida pública, espaço público, publicidade e esfera pública.

Já na concepção de Oliveira (2001), além de ser muito difícil tratar de intelectuais, conhecimento e espaço público, eles nascem juntos. Contudo, o autor traz no bojo um novo elemento que difere dos demais: a desprivatização do espaço. Com isso, o espaço passa a ser um lugar público, eficaz para a operação do novo modo de ser da sociedade. Muda, portanto, o papel do intelectual, que se desloca dos antigos aparelhos e das antigas formas de dominação, e surge o autônomo. O elemento novo que aparece no diálogo com Oliveira (2001) é o "poder".

Gurza Lavalle (2005) mostra que, na própria cotidianidade, existe uma ambiguidade quanto à especificação conceitual do espaço público. Dessa forma, ao longo dos séculos, as terminologias adquiriram características distintas, configurando novos sentidos. Ao apresentar os dissensos, teorias e dimensões do espaço público, indica que todo modelo teórico adotado implica riscos, principalmente no que se refere às abordagens "fenomenológicas", que lançam mão da polissemia do termo "público".

Muitos foram os teóricos que contribuíram na conceituação do espaço público (em especial, Hannah Arendt e Jurgen Habermas) moderno, mesmo que nem todos desempenhem uma função modelar no debate contemporâneo. A leitura e interpretação dos autores citados não se constituem como uma tarefa simples, mas carregada de dificuldades, tendo em vista o nível de complexidade inerente à conceituação de toda categoria, fundamental na tradição da filosofia e do pensamento político de Ocidente; sequer os contornos mais gerais pressupostos na denominação "espaço público moderno" são isentos de 
controvérsia, ou seja, enquanto Habermas (1962) aponta para o potencial democrático e de racionalização do poder nele presentes, em oposição a ele, Koselleck firma a hipocrisia, e não as energias democratizadoras, como verdadeiro atributo a impregnar essa dimensão burguesa da vida social, diferentemente de Arendt (1958), que apresenta o espaço público como instância da realização plena da condição humana mediante uma das atividades fundamentais da vida. Já o espaço público apresentado por Gurza La Valle (2005) possui três dimensões: público como dimensão "social", público como dimensão "política" e público como dimensão "comunicativa". Portanto, para melhor apresentar a relação entre dimensões e modelos de espaço público, Habermas é o mais influente, uma vez que sua obra transita em um diagnóstico histórico-sociológico centrado na dimensão social da emergência do espaço público moderno. A instância e interpretação habermasiana da gênese do espaço público estão centradas na dimensão social deste.

Para Oliveira (2001), quem perde com a redução do espaço público é a polis; é exatamente a política que perde, pois a polis é o lugar da interlocução. Não há interlocução na comunicação. Já Innerarity (2010) apresenta, em parte de sua obra $O$ novo espaço público, o propósito de examinar a ideia do espaço público e das suas transformações nas sociedades contemporâneas. A hipótese fundamental parte da ideia de que o espaço público e o ambiente em que se articula o comum e onde são tratadas as diferenças não são uma realidade que está posta, mas uma construção. O autor ainda expõe a necessidade de introduzir procedimentos de reflexão numa vida política que costuma estar dominada pelo imediato da tirania do presente. O espaço público deveria, no entanto, ser uma instância de observação e reflexão mediante a qual os membros de uma sociedade produzissem uma realidade comum. 
Para Meiners et al. (2020, p. 2), os Espaços Públicos são lugares interessantes para se refletir sobre a trialética lefebvreriana entre o espaço percebido, concebido e vivido, assim como apontado por Soja (1996). Enquanto percebidos - materializados formalmente e legalmente como espaços públicos -, eles precisam também ser concebidos, ou seja, reconhecidos, ter uma expressão cognitiva e simbólica.

Autores como Carmona (2010, 2014), Gomes (2006), Jacobs (1961), Whyte (2001) e Zeisel (2006) também trazem em sua base teórica uma série de elementos fundamentais para discutir o espaço urbano, a vida social nas cidades, a exclusão, o cuidado com o espaço público, o controle do espaço público, a comunicação não verbal, como a cidade pode ser lida, como os espaços públicos das cidades funcionam.

Pela primeira vez na história da humanidade, a população urbana é maior que a população rural. As cidades cresceram de forma rápida, com tendência para que tal crescimento continue nas próximas décadas do século XXI, o que demandará mudanças significativas em seu planejamento urbano, com uma política urbana integrada para desenvolver, conforme cita Gehl (2013), cidades vivas, seguras, sustentáveis e saudáveis. O autor ainda pontua que é preciso reforçar a função social do espaço da cidade como local de encontro, favorecendo, sobretudo, os objetivos da sustentabilidade social, para uma sociedade democrática e aberta.

Dessa forma, é preciso pensar nos espaços públicos urbanos a partir da dimensão urbana, pois historicamente, se observarmos as cidades, as estruturas urbanas e o planejamento influenciam seu comportamento e formas de funcionamento. Tornar a cidade viva significa um chamamento para que as pessoas caminhem, pedalem ou mesmo permaneçam e se sentem nos espaços da cidade. Nesse sentido, muitas cidades no mundo, como Copenhague (Dinamarca) e Melbourne (Austrália), passaram a estruturar e organizar seus espaços públicos, melhorando as condições, incluindo a redução do tráfego, construção de grandes calçadões, praças, melhoria no mobiliário urbano, com 
ampliação dos espaços verdes, ocasionando uma maior circulação de pessoas e de tempo de permanência e, consequentemente, um crescimento na vida urbana.

No Brasil, (re)pensar as cidades tem sido um dos grandes desafios para arquitetos, urbanistas, planejadores urbanos, geógrafos, historiadores, sociólogos e demais profissionais responsáveis por responder a questionamentos sobre como será o futuro dos espaços públicos pós-pandemia, pois os impactos provocados pela Covid-19 trazem inúmeras e profundas consequências não só na vida urbana, mas também nos hábitos e comportamentos diário das pessoas. Diante de tantas incertezas, é preciso (re)pensar a vida urbana em diversos aspectos, como defendem alguns teóricos que discutem e se debruçam sobre o entendimento dos espaços públicos urbanos.

Conforme o Observatório das Metrópoles, há muito se tem tratado o direito à cidade como tema central nas discussões urbanísticas - cidades mais justas, seguras, sustentáveis, inclusivas e saudáveis e, nesse sentido, com ampla garantia de acessibilidade aos seus espaços públicos. Assim, como será possível viver juntos nos espaços públicos no pós-pandemia?

\section{OS ESPAÇOS PÚBLICOS E O TURISMO}

Quando nos referimos e abordamos a questão dos espaços públicos, não podemos deixar de relacionar com o turismo, tendo em vista que é um fenômeno reconhecido pela capacidade de transformar e reorganizar o espaço geográfico como um todo, incluindo os espaços públicos. Essa reorganização e transformação do espaço ocorrem por meio da articulação entre políticas públicas, setor privado, comunidade local e a inter-relação com diversas ciências. Nesse sentido, "duas características intrínsecas ao turismo o diferenciam, fundamentalmente, de outras atividades econômicas ou produtivas. Uma delas é o fato de o turismo ser, antes de qualquer coisa, uma 
prática social. A outra é o fato de ser o espaço seu principal objeto de consumo" (CRUZ, 2006, p. 338).

Com isso, podemos perceber a importância que os espaços públicos apresentam para o desenvolvimento da atividade turística, visto que o espaço geográfico e, consequentemente, os espaços públicos constituem seu principal objeto de consumo, ou seja, são esses espaços que configuram os atrativos turísticos e compõem, com os serviços turísticos, infraestrutura básica e serviços urbanos de apoio, o chamado produto turístico, que é comercializado pelas agências de viagens e consumido no próprio local pelo turista.

O turismo se destaca como um fenômeno de grande importância socioeconômica, haja vista a capacidade de geração de divisas, postos de trabalho, com consequente desenvolvimento local e regional. Levando em consideração as características da atividade turística, como prática essencialmente social, cuja existência depende da mobilidade das pessoas, ela tem sido profundamente afetada pela pandemia de Covid-19, cujos impactos têm ocorrido em escala global, afetando diretamente e em maior proporção os destinos cuja economia é mais dependente da atividade turística - obviamente, os demais destinos, em que o turismo representa um percentual menor do Produto Interno Bruto (PIB), também têm sido afetados. Isso ocorre principalmente devido às medidas de isolamento social necessárias para a diminuição do contágio e propagação do vírus da Covid-19. Com isso, tivemos a suspensão de viagens e o fechamento de fronteiras em todo o mundo, em 2020. Muitos atrativos foram fechados por serem locais com grande aglomeração de pessoas e têm seguido fechados ou com restrição de acesso nesse período de grave crise sanitária global.

Essas medidas reduzem não somente o turismo internacional, mas também o turismo doméstico, pois a necessidade de isolamento social é igualmente indispensável aos residentes e ocasiona consequências negativas para o turismo. Analisando o cenário mundial do turismo, a partir de 2009, verifica-se um declínio de $4 \%$ nas chegadas de turistas internacionais em todo o mundo, devido à crise econômica mundial, porém 2010 foi totalmente 
diferente, demonstrando uma recuperação muito rápida do setor, que atingiu um aumento expressivo de 6,7\%. A partir de então, a atividade apresentava sempre crescimento no decorrer dos anos, com destaque para o ano de 2017, cujo acréscimo foi de 7,2\%, de acordo com dados do Barômetro do Turismo de janeiro de 2019, publicado pela Organização Mundial de Turismo (UNWTO).

$\mathrm{O}$ ano de 2019 também apresentou forte crescimento de 3,8\%, porém mais lento que o registrado em 2017, devido principalmente à desaceleração econômica global e às tensões geopolíticas e comerciais (UNWTO, 2019). Para 2020, existia uma estimativa de crescimento em torno de $3 \%$ a $4 \%$, porém isso não se concretizou, em razão da propagação da Covid-19 em escala global, levando a Organização Mundial da Saúde (OMS) a decretar pandemia em março de 2020.

De acordo com a UNWTO, o ano de 2020 foi o pior da história do turismo, registrando um bilhão a menos de chegadas de turistas internacionais em comparação a 2019, uma queda de $74 \%$ em escala global. Em receitas de exportação, o órgão cita uma perda estimada de US\$ 910 bilhões a US\$1,2 trilhão, colocando em risco cerca de 120 milhões de empregos diretos no turismo. Essas estimativas representam uma queda sem precedentes, com a atividade regredindo aos patamares que se encontrava em 1990, ou seja, a pandemia de Covid-19 para o setor do turismo, até dezembro de 2020, fez com que ele regredisse 30 anos, de acordo com a UNWTO (2021).

É possível perceber os impactos gerados por essa crise sanitária em todas as regiões do mundo, que apresentaram índices de queda semelhantes, excetuando-se a Ásia e o Pacífico, epicentro do início da pandemia de Covid-19, que tiveram índices de queda de turistas internacionais ainda mais elevados, conforme evidenciado no Gráfico 1. 
Gráfico 1 - Chegada de turistas internacionais em 2020.

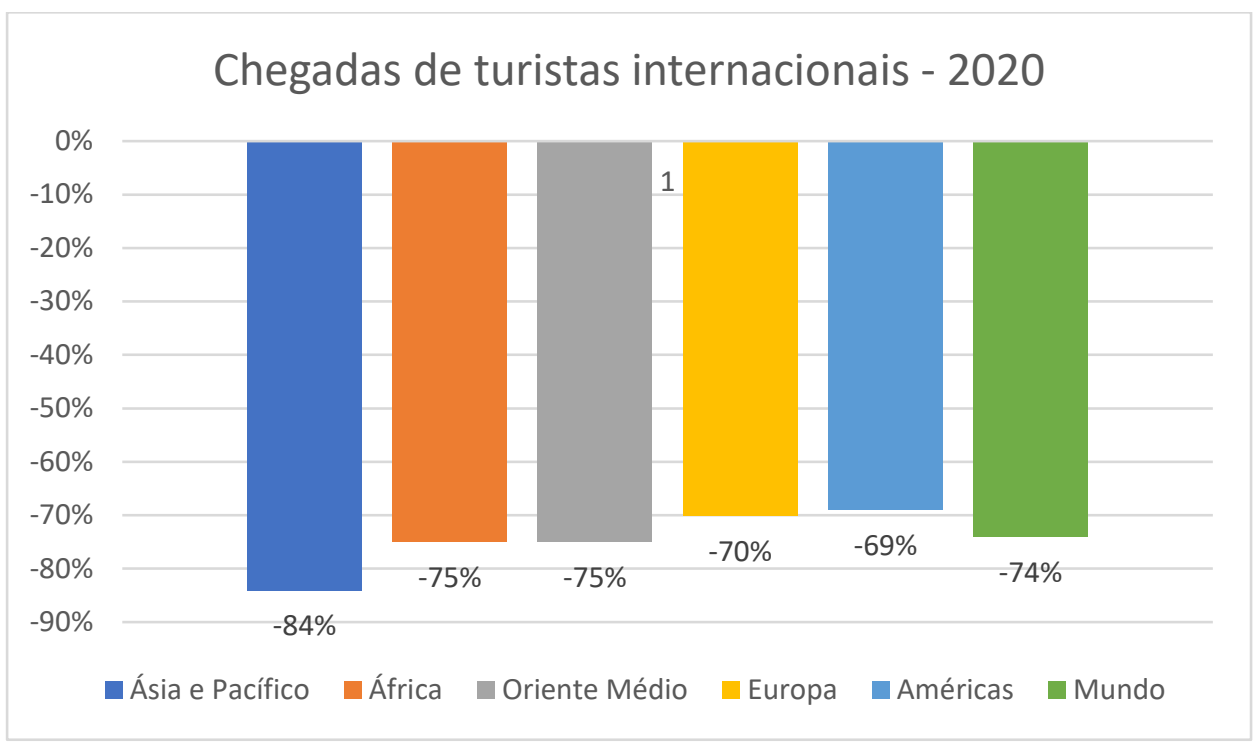

Fonte: UNWTO, 2021.

O Brasil, até 2019, vivenciava um período de destaque no turismo, apresentando crescimento de 2\% em 2018 e 2,4\% em 2019 no volume de receitas provenientes dos serviços de turismo, de acordo com 0 Instituto Brasileiro de Geografia e Estatística (IBGE). No mesmo período, o setor expandiu o seu Valor Bruto Adicionado (VAB) em 3\% ao ano, taxa muito acima do crescimento apresentado pelo PIB brasileiro, de 1,1\% (TOMÉ, 2020). De acordo com o Conselho Mundial de Viagens e Turismo (WTTC), a atividade representou 7,7\% do PIB nacional, ou seja, uma contribuição direta e indireta de US\$139,9 bilhões em 2019. Quanto aos empregos gerados de forma direta e indireta, o setor foi o responsável por 7,9\% do total de postos do Brasil, cerca de 7,4 milhões de empregos, além de atrair US\$ 5,9 bilhões na forma de receitas internacionais do turismo, em 2019 (TOMÉ, 2020).

Esses dados nos permitem perceber e evidenciar a crescente expressividade econômica e social da atividade turística até o período mencionado. Tal fato também pode ser relacionado ao aumento do turismo doméstico, que, nesse mesmo ano, apresentou crescimento de $1,72 \%$ no número de desembarques nacionais nos aeroportos brasileiros, em comparação 
com 2018 (TOMÉ, 2020), impulsionando, assim, a economia do país e redistribuindo divisas.

No entanto, esse cenário de crescimento apresentou uma queda abrupta, com retração histórica, a partir de março de 2020, quando a OMS decretou a pandemia de Covid-19, fato que afetou drasticamente o turismo, inclusive no Brasil. Quando comparamos a variação mensal do índice de receita e volume das atividades turísticas de 2019 com o obtido em 2020, fica muito evidente a queda histórica evidenciada no período de pandemia em relação ao momento anterior, o que ocorreu em maior escala entre março e agosto de 2020. A partir de setembro, tem-se um aumento tanto na receita quanto no volume das atividades turísticas, porém ainda ficam muito distantes dos resultados apresentados pelo setor em 2019.

Gráfico 1.2 - Variação mensal do índice de receita nominal das atividades turísticas no Brasil - \%

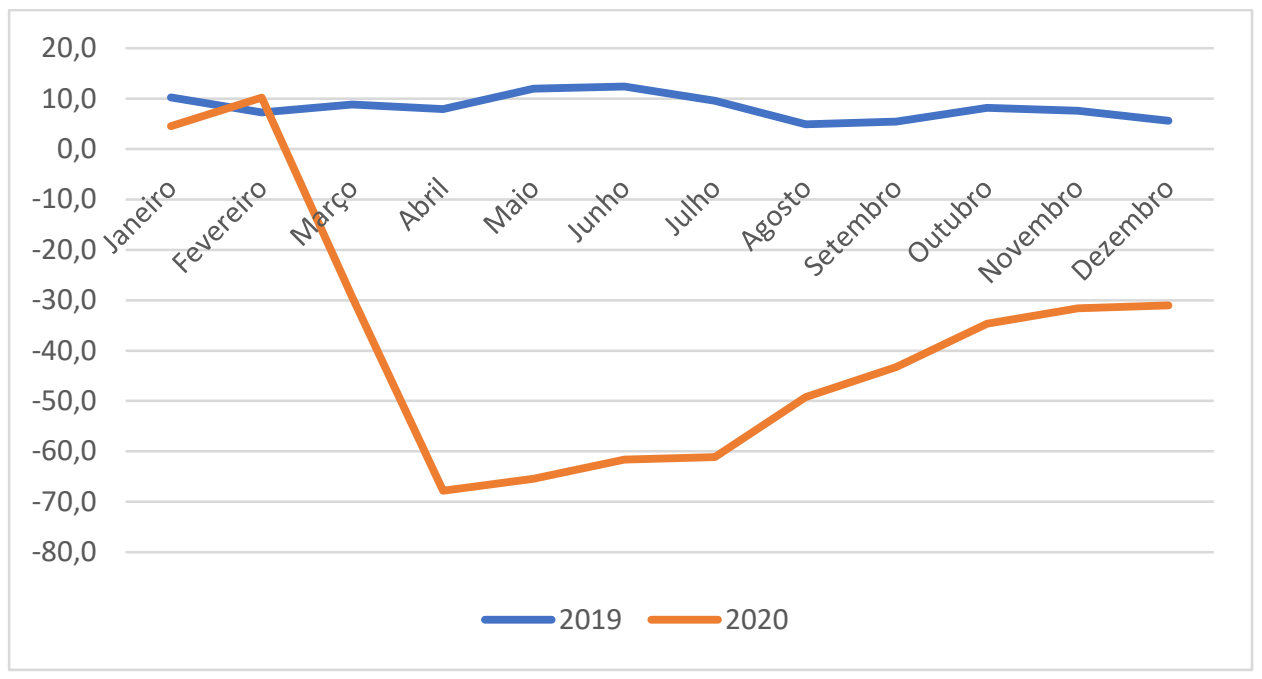

Fonte: IBGE - Pesquisa Mensal de Serviços, 2020. 
Gráfico 1.3 - Variação mensal do índice de volume das atividades turísticas (Brasil) - \%

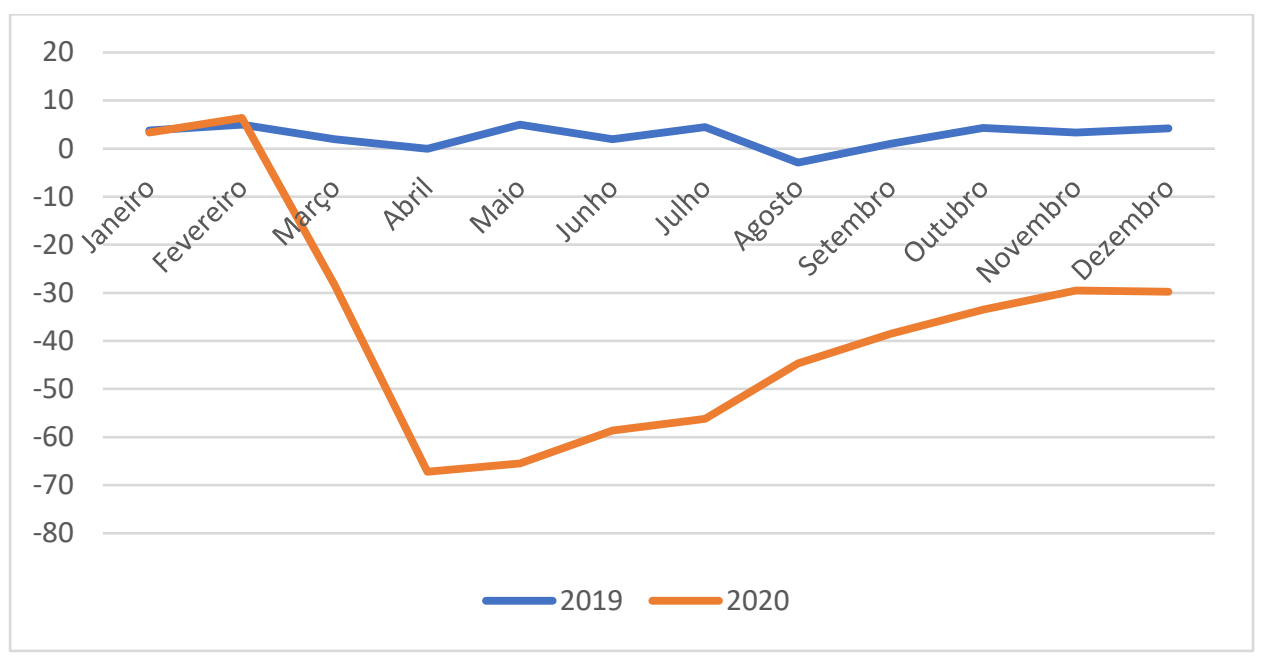

Fonte: IBGE - Pesquisa Mensal de Serviços, 2020.

As receitas provenientes dos serviços de turismo encolheram 38,1\% em 2020 e o volume das atividades turísticas, 36,9\%, em comparação com 2019, de acordo com o IBGE e a Confederação Nacional do Comércio de Bens, Serviços e Turismo (CNC). Seguindo a tendência global, esse foi o pior ano da história para o setor de turismo brasileiro. O Distrito Federal e o Rio Grande do Sul foram os estados que apresentaram maiores quedas, tanto em receita quanto em volume das atividades turísticas. 
Gráfico 1.4 - Variação acumulada em 12 meses do índice de receita nominal da

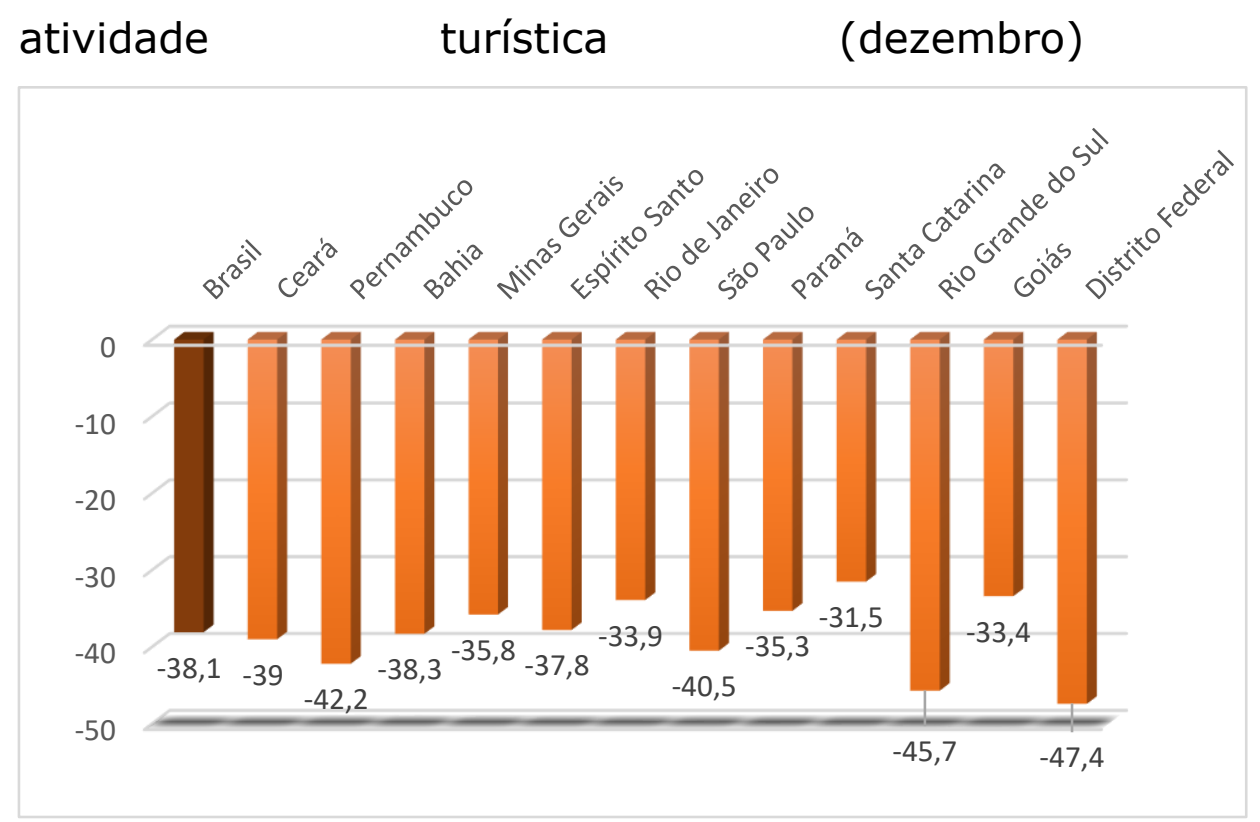

Fonte: IBGE - Pesquisa Mensal de Serviços, 2020.

Gráfico 1.5 - Variação acumulada em 12 meses do índice de volume das atividades turísticas (dezembro) - 2020.

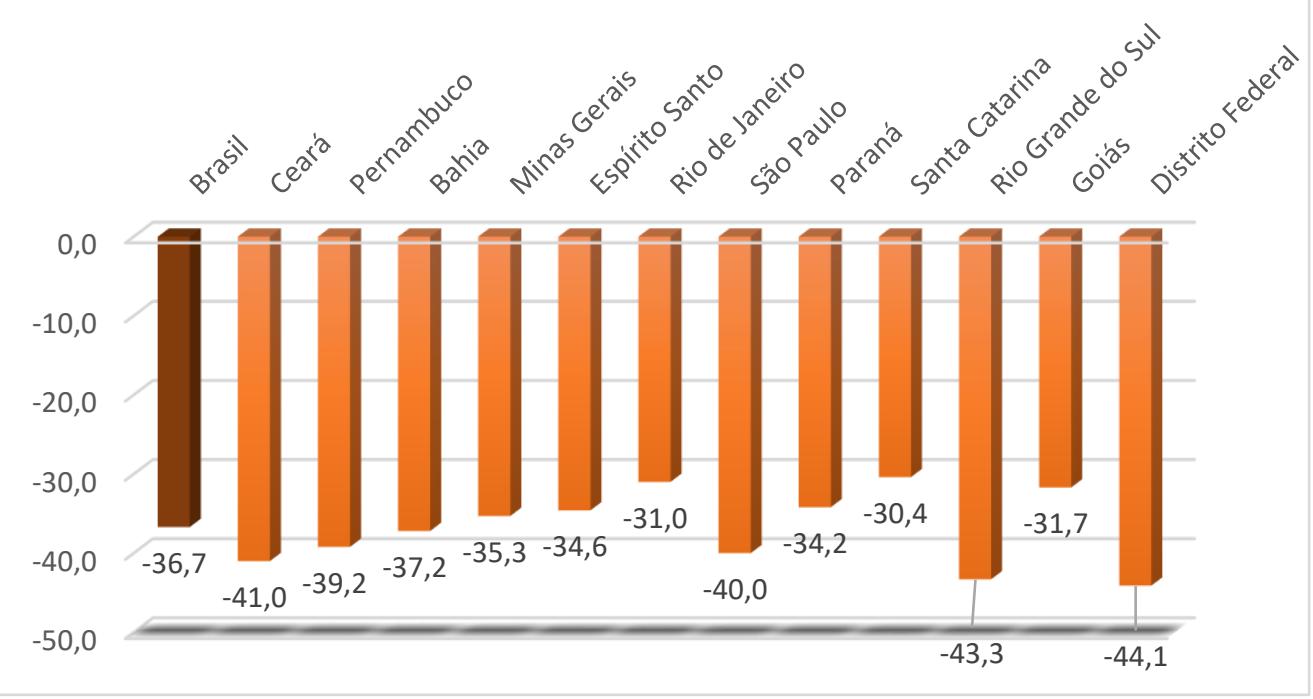

Fonte: IBGE - Pesquisa Mensal de Serviços, 2020.

De acordo com a CNC, os serviços de alojamento e alimentação $(-36,8 \%)$ e o transporte aéreo $(-36,9 \%)$ foram os segmentos turísticos que apresentaram maiores quedas em 2020, resultado direto das medidas de isolamento social adotadas para minimizar o avanço da Covid-19 no Brasil. Essa retração da 
demanda gerou quedas nos preços praticados nesses segmentos - de acordo com o Índice Nacional de Preços ao Consumidor Amplo (IPCA; CNC, 2021), a queda foi de $4,5 \%$ em 2020 , com o preço médio das passagens variando $-17,2 \%$ e os serviços de hospedagem, $-8,1 \%$.

Comparando os setores econômicos no primeiro bimestre de 2020, verificamos que nenhuma outra atividade apresentou retração tão expressiva quanto o setor turístico. É evidente um acréscimo nas atividades de comércio e indústria, no período de pandemia, em comparação com janeiro e fevereiro de 2020. Já o setor de serviços apresentou um declínio de $4,2 \%$ e o turismo, uma perda de 29,7\% em comparação aos dois primeiros meses de 2020.

Gráfico 1.6 - Níveis de atividades por setor, em dezembro de 2020, em relação à média de janeiro e fevereiro de 2020 .

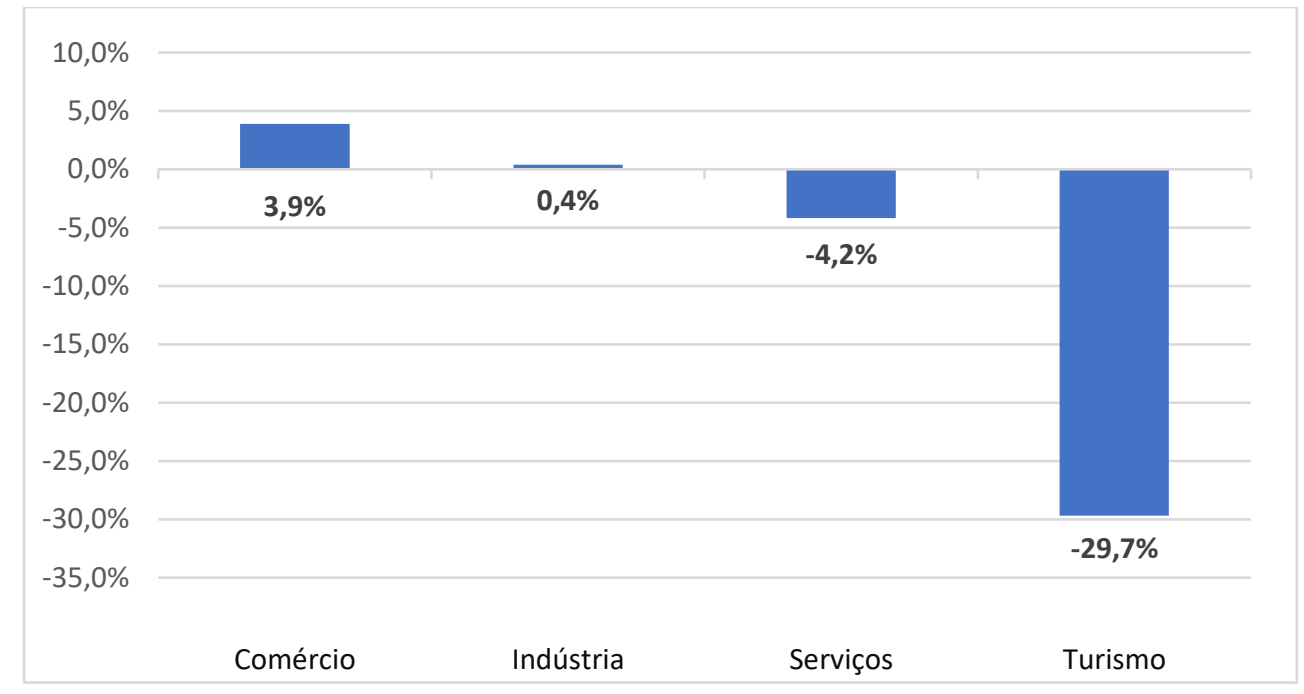

Fonte: IBGE e CNC, 2021.

A atividade mais impactada pela grave crise sanitária em que nos encontramos, de fato, é o turismo, que tem acumulado perdas desde o início da pandemia, apresentando maiores valores nos meses de abril e maio. Ao analisar - Gráfico 1.7, verifica-se uma diminuição na curva de perdas, porém o acumulado nos 11 meses, até janeiro de 2021, totaliza mais de R\$274 bilhões (CNC, 2021). 
Gráfico 1.7 - Perdas de faturamento no setor de turismo no Brasil.

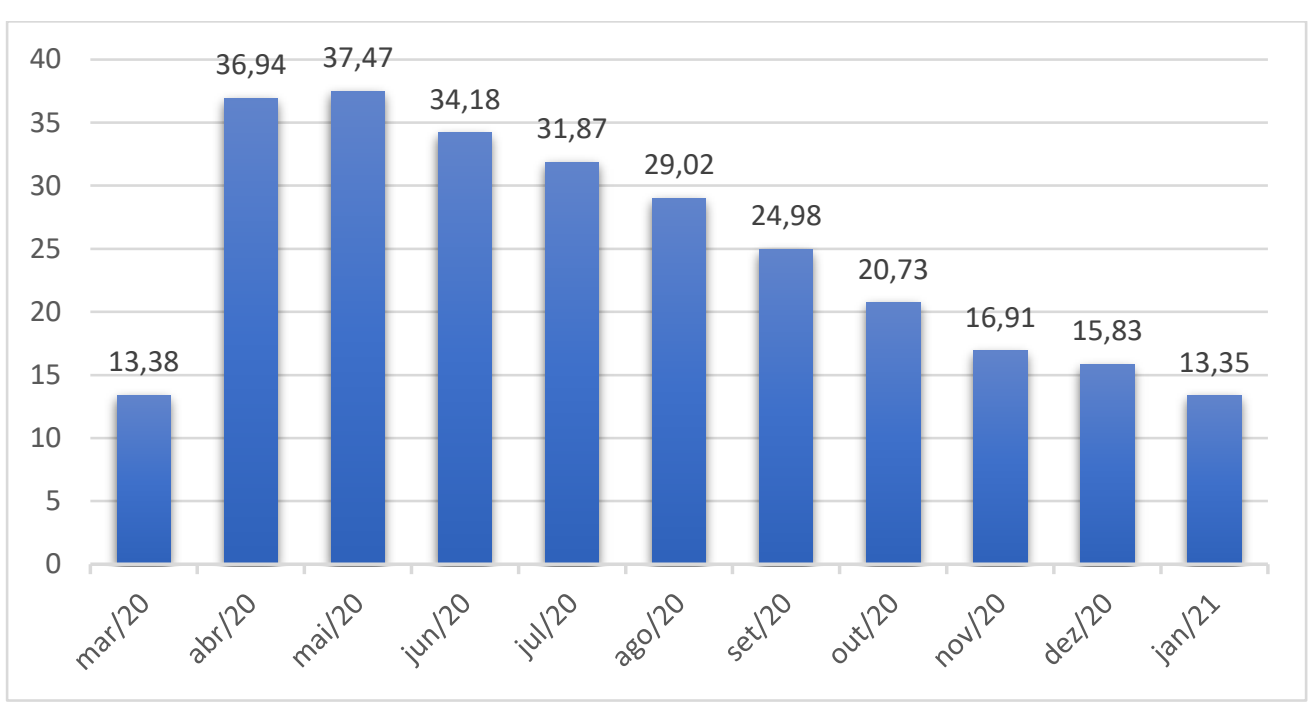

Fonte: CNC, 2021.

As perdas evidenciadas no setor de turismo impactaram a atividade como um todo e, como consequência, refletiram no mercado de trabalho, acarretando queda nos postos formais de trabalho. De acordo com a CNC (2021), o Cadastro Geral de Empregados e Desempregados (Caged) demonstrou que o número de empregos formais no turismo retraiu $12,8 \%$, ou seja, 397,1 mil postos de trabalho a menos. Já construção, agropecuária, indústria e comércio apresentaram índices positivos, ou seja, uma maior oferta de vagas de trabalho formais.

As perdas no turismo foram alavancadas principalmente pelos bares e restaurantes, transporte rodoviário e meios de hospedagem, que sofreram mais diretamente os impactos da crise gerada pela Covid-19 e apresentaram perdas de: $211,1 \mathrm{mil}, 90,7 \mathrm{mil}$ e 56,5 mil postos de trabalho, respectivamente (CNC, 2021). Somente essas três áreas foram responsáveis por mais de $90 \%$ das vagas formais de trabalho perdidas. 
Gráfico 1.8 - Postos formais de trabalho - saldo entre admissões e demissões, por setores (2020).

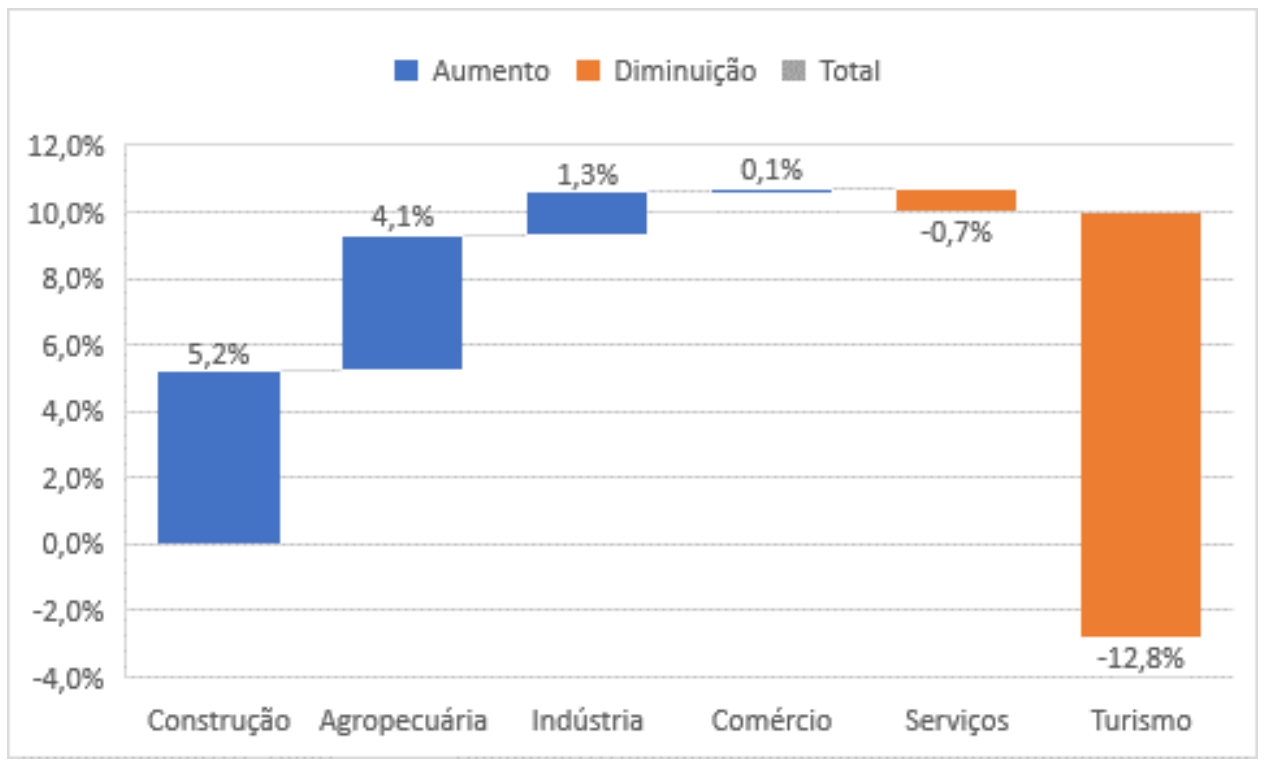

Fonte: CNC, 2021.

As perspectivas para o setor turístico global envolvem a previsão de recuperação e retorno aos níveis pré-pandemia após o ano de 2023, de acordo com a UNWTO (2021). Para o Brasil, a CNC estima que em 2021 o setor turístico encolherá 9,7\% e poderá retornar ao nível de 2019 somente no segundo trimestre de 2023. De acordo com Cruz (2020), para os brasileiros, a perda de poder aquisitivo, a grande desvalorização do real em relação ao dólar, o receio de maior exposição ao contágio e o fechamento das fronteiras têm inibido o turismo emissivo internacional.

Ainda em relação às perspectivas pós-pandemia para a atividade, a UNWTO indica que a pandemia poderá acarretar mudanças no turismo em escala global, com maior ênfase para o turismo doméstico. Nesse sentido, Cruz (2020, p. 12) destaca que "as viagens de final de semana e feriados, abarcando deslocamentos por automóvel e para localidades próximas do lugar de moradia têm sido o mote da retomada dos deslocamentos motivados por lazer".

Para a retomada do turismo após a pandemia de Covid-19, é notável a urgência de investimentos em políticas públicas e de planejamento urbano e 
turístico. Isso será extremamente necessário, pois a sustentabilidade é um tema estratégico para o retorno do turismo, de acordo com a UNWTO (2020). Nessa direção, destacam-se as cidades e suas respectivas capacidades de resiliência urbana, que tenderão a receber maior número de turistas regionais, exigindo, dentro dos novos parâmetros necessários para o período pós-pandemia, uma reestruturação e ressignificação dos espaços, principalmente públicos, além de suas formas de uso e apropriação.

Espera-se que o período de pandemia possa fazer emergir um turista que busque o desenvolvimento e prática do turismo de forma mais consciente, cujas escolhas sejam resultantes de uma reflexão, com o intuito de agregar maior valor à sua experiência, gerando maiores impactos socioeconômicos positivos e a adoção de práticas e comportamentos mais sustentáveis (IRVING; COELHO; ARRUDA, 2020). Estima-se, ainda, uma diminuição do turismo de massa, que se caracteriza por gerar diversos impactos sociais e ambientais negativos.

Em meio a essa retração histórica do turismo como atividade econômica e prática social, espera-se que a sua recuperação ocorra de forma rápida, sustentável e ressignificada, com o desenvolvimento de uma atividade mais amadurecida, planejada e valorizada localmente, principalmente após os grandes impactos socioeconômicos sofridos em decorrência da pandemia de Covid-19.

\section{CONSIDERAÇÕES FINAIS}

O ano de 2020 apresentou-se de forma atípica no mundo e no Brasil, em função da pandemia do novo coronavírus, quando a OMS decretou a pandemia de Covid-19, alterando, sobretudo, os espaços públicos urbanos, que, por questão de segurança e mesmo para que o vírus não se espalhasse, foram fechados, não havendo acesso do público. Isso ocasionou, entre outros fatores, uma drástica redução das atividades ligadas ao setor do turismo, com uma queda abrupta e uma retração histórica no que tange ao número de empregos 
formais ligados ao setor, além de um encolhimento das receitas provenientes do setor.

A perspectiva para o setor de turismo ligado ou não diretamente aos espaços públicos, segundo a própria UNWTO, é uma mudança para uma ênfase maior no turismo doméstico, com um olhar maior por parte do poder público em investimentos no que se refere a políticas públicas e de planejamento urbano e turístico. O que se espera no período pós-pandemia é a urgência de uma reestruturação e ressignificação dos espaços, principalmente públicos, com as suas formas de uso e apropriação, considerando o que destaca Gehl (2013) ao afirmar que as cidades precisam ser vivas, seguras, sustentáveis e saudáveis, buscando, por parte dos planejadores urbanos, a adoção de práticas e comportamentos mais sustentáveis, como pontuam Irving, Coelho e Arruda (2020), de modo a, com base no Objetivo do Desenvolvimento Sustentável 11, até 2030, aumentar a urbanização inclusiva e sustentável e as capacidades para o planejamento e gestão de assentamentos humanos participativos, integrados e sustentáveis, em todos os países.

\section{REFERÊNCIAS}

Arendt H. Entre o passado e o futuro. São Paulo: Perspectiva; 2007.

ARENDT, H. A condição humana. 10. ed. Rio de Janeiro: Forense Universitária, 2007.

ASCHER, François. Os Novos Desafios do Urbanismo. Tradução e apresentação Nadia Somekh. São Paulo: Romano Guerra, 2010. 104 p. (Coleção RG Bolso, 4). CARMONA, M. One: Critique. In: Journal of Urban Design, v. 15. n. 1, Fev. 2010, p. 123-148. Re-theorising contemporary public space: a new narrative and a new normative. CNC - Confederação Nacional do Comércio de Bens, Serviços e Turismo. Sumário Econômico. n. 1657, mar. 2021. Disponível em: http://stage.cnc.org.br/editorias/economia/periodicos/sumario-economico-1657. Acesso em: mar. 2021.

CRUZ, R. C. A. Impactos da pandemia no setor de turismo. Jornal da USP. Disponível em: https://jornal.usp.br/?p=334700. Acesso em: dez. 2020.

CRUZ, R. C. A. Planejamento governamental do turismo: convergências e contradições na produção do espaço. In: LEMOS, A. I. G. de; SILVEIRA, M. L.; ARROYO, M. América Latina: cidade, campo e turismo. São Paulo: CLACSO, Consejo Latinoamericano de Ciencias Sociales, 2006, p. $337-350$.

FGV Projetos - Fundação Getúlio Vargas. Impacto Econômico do Covid-19

GALVÊAS, E. Síntese da Conjuntura. Rio de janeiro: CNC - Confederação Nacional do Comércio de Bens, Serviços e Turismo. Jan. 2021. Disponível em: http://www.cnc.org.br/editorias/economia/periodicos/sintese-da-conjuntura-31012021. Acesso em fev. 2021.

GEHL, Jan. Cidades para Pessoas. Tradução Anita Di Marco. 2.ed. São Paulo, Perspectiva, 2013. 
GOMES, R.C.C. A condição Urbana, Ensaios de Geopolítica e a Cidade. Rio de Janeiro: Bertrand Brasil, 2006.

GURZA LAVALLE A. As dimensões constitutivas do espaço público - Uma abordagem préteórica para lidar com a teoria. In: Espaço \& Debates, v.25, n. 46, jan/jul, 2005, p. $33-44$. HABERMAS, J. Theorie des Kommunikativen Handelns Frankfurt am Main: Suhrkamp, 1995.

IBGE - INSTITUTO BRASILEIRO DE GEOGRAFIA E ESTATÍSTICA. Pesquisa Mensal de Serviços - PMS. Disponível em: https://www.ibge.gov.br/estatisticas/economicas/servicos/9229pesquisa-mensal-de-servicos.html?=\&t=destaques. Acesso em fev. 2021.

INNERARITY, D. O novo espaço público. Lisboa: Texto Editores, 2010.

IRVING, Marta de Azevedo; COELHO, André Meyer; ARRUDA, Thaiane Oliveira. Turismos, sustentabilidades e pandemias: incertezas e caminhos possíveis para planejamento turístico no horizonte da Agenda 2030. Revista Acadêmica Observatório de Inovação do Turismo, [S.I.], p. 73-105, dez. 2020. ISSN 1980-6965. Disponível em: <http://publicacoes.unigranrio.edu.br/index.php/raoit/article/view/666 >. Acesso em: fev. 2021.IUC-LAC. Programa Internacional de Cooperação Urbana na América latina e no Caribe. Impacto e Respostas das Cidades IUC-LAC ao Covid-19. Disponível em: http://IucLa.Eu/Pt-Br/Impacto-E-Respostas-Das-Cidades-Iuc-Lac-Ao-Covid-19/. Acesso em: fev. 2021. JACOBS, J. (2009). Morte e vida das grandes cidades. Tradução de Carlos S. Mendes Rosa. São Paulo: Martins Fontes.

JACOBS, J. (1961). Morte e vida das grandes cidades. Tradução de Carlos S. Mendes Rosa. São Paulo: Martins Fontes. KOSELLECK, Reinhart. Crítica e crise. Tradução: Luciana Villas-Boas Castelo-Branco. Rio de Janeiro: UERJ/Contraponto, 1999, 256 páginas. MINISTÉRIO DO TURISMO. Relatório de Impacto da pandemia de COVID-19 nos setores de turismo e cultura no Brasil. Disponível em: http://www.dadosefatos.turismo.gov.br/boletins/item/401relat\%C3\%B3rio-de-impacto-da-pandemia-de-covid-19-nos-setores-de-turismo-e-cultura-nobrasil/401-relat\%C3\%B3rio-de-impacto-da-pandemia-de-covid-19-nos-setores-de-turismo-ecultura-no-brasil.html. Acesso em: dez. 2020.

OLIVEIRA, F. Intelectuais, conhecimento e espaço público. In: Revista Brasileira de Educação, n.18, set/out/nov/dez, 2001.

Propostas para o Turismo Brasileiro. Disponível em: <https://static.poder360.com.br/2020/04/Impacto-Economico-do-Covid-19-Propostas-para-oTurismo-Brasileiro.pdf>. Acesso em: dez. 2020.

TOMÉ, L. M. Setor de Turismo: Impactos da Pandemia. Caderno Setorial ETENE. Banco do Nordeste. Ano 5, n. 122, ago. 2020.

UNWTO - World Tourism Organization. 2020: A year in review. Disponível em: https://www.unwto.org/covid-19-and-tourism-2020. Acesso em fev. 2021.

UNWTO - World Tourism Organization.

2020: worst year in tourism history with 1 billion fewer international arrivals. Disponível em https://www.unwto.org/news/2020-worst-year-in-tourism-history-with-1-billionfewer-international-arrivals. Acesso em fev. 2021.

UNWTO - World Tourism Organization. Tourism back to 1990 levels as arrivals fall by more than 70\%. Disponível em: https://www.unwto.org/news/tourism-back-to-1990-levels-asarrivals-fall-by-more-than-70. Acesso em: fev. 2021.

UNWTO - World Tourism Organization. UNWTO World Tourism Barometer and Statistical Annex. v. 19, jan. 2021. Disponível em: https://www.eunwto.org/doi/abs/10.18111/wtobarometereng.2021.19.1.1. Acesso em: fev. 2021.

UNWTO - World Tourism Organization. World Tourism Barometer, n. 18, jan. 2020.

Disponível em: https://www.unwto.org/world-tourism-barometer-n18-january-2020. Acesso em: fev. 2021.W. E. M. A. MEINERS et al. I Espaço público de propriedade privada em Curitiba (Brasil): O Boulevard da Neo Superquadra Privately Owned Public Space In Curitiba (Brazil): The Neo Superquadra Boulevard. Oculum Ensaios, Campinas, 17, 2020. |http://periodicos.puccampinas.edu.br/seer/index.php/oculum/article/view/4330/3012

WTTC - World Travel e Tourism Council. Brazil: 2020 annual research: key highlights. Disponível em: https://wttc.org/Research/Economic- 
Impact/moduleId/1445/itemId/91/controller/DownloadRequest/action/QuickDownload. Acesso em dez. 2020.

ZEISEL, J. Inquiry by Design. Environmental/Behavior/Neuroscience in Architecture, Interiors, Landscape, and Planning. New York: W. W. Norton \& Company, Inc., 2006. 


\section{CAPÍTULO 2 - A DISTRIBUIÇÃO DE VACINAS PARA COVID-19 E A ORDEM INTERNACIONAL: UM ENSAIO TEÓRICO ENTRE A GEOGRAFIA E A ESCOLA INGLESA DE RELAÇÕES INTERNACIONAIS}

\section{ANDRÉ FRANCISCO MATSUNO DA FROTA4 VERA CRISTINA SCHELLER DOS S. ROCHA ${ }^{5}$}

\section{INTRODUÇÃO}

O problema de pesquisa que este artigo se propõe a explorar é: de que maneira a distribuição de vacinas para Covid-19 no espaço geográfico global ${ }^{6}$ é condicionada pela ordem internacional, tal como entendida pela Escola Inglesa de Relações Internacionais ${ }^{7}$ ?

O artigo tem por objetivo explorar o potencial de relação entre a geografia da vacinação no mundo e o conceito de ordem internacional. Trata-se de uma pesquisa exploratória ${ }^{8}$, que resultou na formulação de uma hipótese de trabalho. O texto deve ser entendido como um ensaio teórico de aproximação ${ }^{9}$ entre a

\footnotetext{
4 Professor de Relações Internacionais e Geociências do Centro Universitário Internacional Uninter.

${ }^{5}$ Graduada em Licenciatura em Geografia pela Universidade Estadual de Londrina- UEL e em Pedagogia pela UNINTER; pós-graduada em Gerenciamento de Recursos Ambientais, Direito Ambiental, Educação Ambiental e Educação de Jovens e Adultos.

${ }^{6} \mathrm{O}$ conceito de espaço geográfico global pode ser entendido mediante duas características: um sistema internacional de estados soberanos e um desenho geográfico global. Para estudo aprofundado do tema, ver Jardeweski e Frota (2019, p. 48).

7 A escola inglesa de relações internacionais é uma perspectiva de estudo da política internacional, notadamente conhecida por estabelecer o seu objeto como o estudo da sociedade internacional.

${ }^{8}$ Adotamos a definição sugerida por Bervian, Cervo, e Silva (2007).

${ }^{9}$ Adotamos o denominador comum sugerido por Soares, Picolli e Casagrande (2018).
} 
geografia da distribuição de vacinas e a Escola Inglesa de Relações Internacionais, em especial, a contribuição de Hedley Bull (2002).

$O$ texto pretende auxiliar estudantes, professores e analistas a formular hipóteses que integrem a geografia e a teoria de relações internacionais, em torno das possíveis variáveis espaciais, normativas e internacionais que contribuem para explicar o modelo de distribuição da vacinação contra Covid-19 no mundo.

O que procuramos estruturar como hipótese é: o início da distribuição global de vacinas contra Covid-19 ocorreu mediante duas lógicas concomitantes e hierarquicamente distintas: um controle distributivo vertical de grande escala, concentrado nos Estados desenvolvedores e seus aliados estratégicos, acompanhado de uma distribuição horizontal e multilateral estatal de menor escala.

\section{A DISTRIBUIÇÃO DE VACINAS NO ESPAÇO GEOGRÁFICO GLOBAL}

A geografia da distribuição de vacinas pode ser representada por dois mapas extraídos da base de dados da Organização Mundial da Saúde (OMS). O primeiro demonstra o momento inicial da vacinação, no intervalo entre os dias 14 e 17 de dezembro de 2020. Neste, os programas de vacinação de cinco países inauguraram o início da vacinação contra a Covid-19 no mundo, a saber: Reino Unido, 14/12/2020; Canadá, 15/12/2020; Rússia e China, 16/12/2020; Israel, 20/12/2020; e Estados Unidos, 21/12/2020. 
Figura 2.1 - Vacinas administradas para cada 100 pessoas - 14 a 21/12/2020.

Daily COVID-19 vaccine doses administered per 100 people, Dec 14, 2020

Shown is the rolling 7-day average per 100 people in the total population. This is counted as a single dose, and may not equal the

total number of people vaccinated, depending on the specific dose regime (e.g. people receive multiple doses).

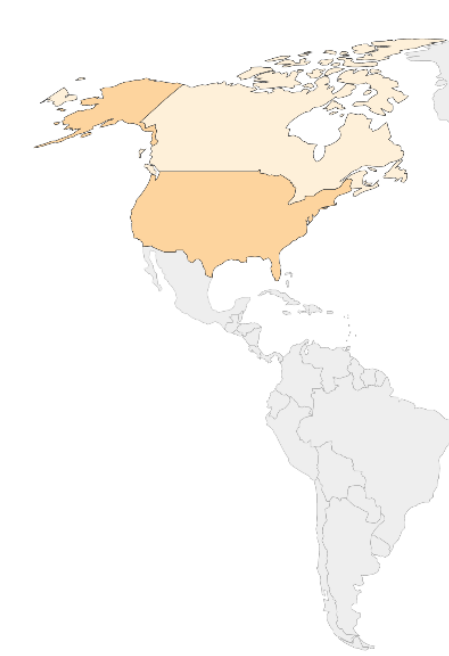

0.1 0.3

Fonte: RITCHIE, Hannah, et al, 2020.

O segundo mapa retrata as mesmas variáveis da Figura 2.1, mas já evidencia um número de vacinas aplicadas para cada 100 pessoas no dia 11/03/2021, precisamente um ano após o início do reconhecimento formal da pandemia pela OMS. O mapa demonstra: (i) uma distribuição desigual no acesso ao imunizante; (ii) uma concentração de doses por habitantes (1 para cada 100) aplicadas em um número seleto de países; (iii) porções do planeta sem qualquer acesso à vacina. 
Figura 2.2 - Vacinas administradas para cada 100 pessoas - 11/03/2021.

Daily COVID-19 vaccine doses administered per 100 people, Mar 11, 2021

Shown is the rolling 7-day average per 100 people in the total population. This is counted as a single dose, and may not equal the

total number of people vaccinated, depending on the specific dose regime (e.g. people receive multiple doses).

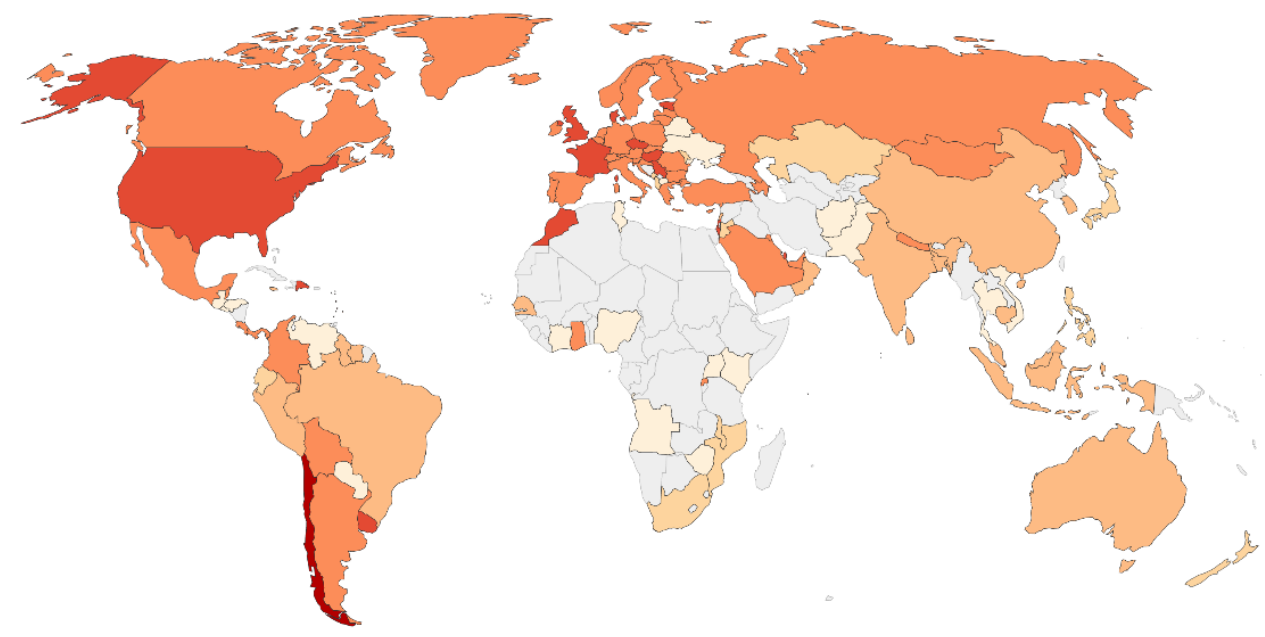

0.3

Fonte: RITCHIE, Hannah, et al, 2020.

A geografia da distribuição das vacinas demonstra uma assimetria entre os países. Ao contrário de um retrato equitativo, os mapas demonstram muitas porções do globo sem qualquer acesso ao recurso, enquanto outras implementam amplos programas de vacinação.

A pergunta que orienta esta pesquisa exploratória é: pode-se identificar uma ordem global que contribui para a compreensão dos mapas de vacinação aqui trazidos?

\section{A BUSCA PELA IDEIA DE ORDEM NA POLÍTICA INTERNACIONAL}

A pergunta teórica que passa a orientar esta investigação foi respondida em um texto da Escola Inglesa de Relações Internacionais, por um de seus 
autores clássicos. Na obra A sociedade anárquica, Hedley Bull (2002) inicia sua investigação sobre como a ideia de ordem pode ser definida e aplicada ao funcionamento das relações entre os $\operatorname{Estados}^{10}$.

Logo no início de seu estudo, Bull estabelece uma orientação de pesquisa, que procura entender a ordem como uma realidade identificável em sua forma mínima. Trata-se de encontrar, em meio ao contexto de relação entre as unidades do sistema de Estados, um conjunto básico de critérios que permita afirmar o que é essa ordem, como ela pode ser definida e sobre quais fundamentos pode ser formulada.

Bull busca os fundamentos da ordem no interior de uma organização política nacional para, em seguida, testar uma extrapolação para o âmbito internacional. Ao fazer essa investigação, o autor apresenta três finalidades mínimas da ordem social: (i) a proteção da vida, apontada como requisito fundacional para a existência de uma ordem social; (ii) a garantia de que os acordos firmados entre dois ou mais indivíduos sejam cumpridos; (iii) a garantia de que a propriedade dos bens seja estável. Esses três objetivos, quando alcançados por uma coletividade, formam uma vida social ordenada, de acordo com o entendimento do autor. Portanto, "a ordem que se procura na vida social não é qualquer ordem ou regularidade nas relações entre os indivíduos ou grupos, mas uma estrutura de conduta que leve a um resultado particular, um arranjo da vida social que promove determinadas metas ou valores" (BULL, 2002 , p. 8). Assim, segundo Frota (2013) o tipo especial de ordem sobre a qual Bull (2002) disserta implica uma ordem exclusivamente orientada a proteger determinados objetivos, notadamente a vida, a verdade e a propriedade.

Os requisitos sugeridos pelo autor ao buscar os objetivos mínimos para o estabelecimento da ordem são deslocados do plano nacional para o nível de análise do sistema internacional. O exercício de extrapolação permite que sejam reconhecidos critérios para a constatação de um grau mínimo de ordem no

10 O conjunto de observações teóricas indicadas nesta seção foi extraído de Frota (2013). 
sistema de Estados. Logo, (i) a proteção da vida, como finalidade prioritária da ordem, passa a ser entendida como a necessidade de preservação da vida humana; (ii) a necessidade de cumprimento dos acordos passa a ser entendida como o respeito aos tratados firmados entre os Estados, ou seja, pacta sunt servanta; (iii) a garantia da propriedade é entendida como um mútuo reconhecimento da soberania entre os Estados nacionais. Em síntese, vida, verdade e propriedade foram extrapolados para: limitação da violência, pacta sunt servanta e soberania, como objetivos mínimos para a existência de uma ordem internacional (FROTA, 2013).

A ordem demonstrada por Bull (2002) é uma ordem minimalista. Ao contrário de uma ordem formada por amplos valores e assentada em amplas garantias formais, sua tese aponta para a existência de um mínimo denominador comum entre o conjunto de Estados que compõem o sistema internacional. A definição de uma ordem internacional deve, portanto, formar um "[...] padrão de atividades que sustente estes objetivos elementares da sociedade de Estados" (BULL, 2002, p. 9).

O tipo de ordem a que o autor faz referência pode ser entendido como uma ordem estática e orientada para proteger seus requisitos elementares. Esses objetivos são elementares porque, no seu entender, são valores políticos que devem ser protegidos, pois permitem o florescimento dos demais valores políticos. Isso significa estabelecer um critério hierárquico entre os objetivos supracitados e os demais. Nota-se, então, uma dependência dos demais valores da ordem internacional de Estados em relação aos três objetivos citados. "Se os indivíduos não tiverem um certo grau de segurança contra a ameaça de morte ou prejuízos, não poderão devotar a energia e a atenção suficientes a outros objetivos, de modo a poder alcançá-los" (BULL, 2002, p. 10). O argumento central do autor está, pois, em demonstrar que, se as três finalidades não forem contempladas, não será possível afirmar a existência de uma ordem internacional de Estados (FROTA, 2013).

Em linhas gerais, as ideias apresentadas por Bull (2002) fornecem elementos conceituais para uma investigação do que pode ser entendido por uma ordem 
internacional. Essa fundamentação proporciona um ponto de partida para investigar os critérios que auxiliam a elaboração de nossa hipótese, em relação à lógica de distribuição de vacinas contra Covid-19 no planeta. O conjunto de mapas parece apontar para uma lógica global na distribuição dos imunizantes, mas até que ponto a ideia de ordem internacional, assim como descrita por Hedley Bull, auxilia a compreender os limites que essa ordem internacional estabelece para distribuição das vacinas no espaço geográfico global?

\section{DOIS MODELOS DE ORDEM INTERNACIONAL: PLURALISMO E SOLIDARISMO}

Diante das imagens apresentadas até agora, que indicam um perfil de distribuição global da vacinação contra Covid-19 e da definição minimalista de ordem internacional, quais nexos entre ambas as dimensões - espaço e valores - são possíveis de ser elaborados?

Como ponto de partida, pode-se afirmar que o espaço internacional é ordenado pela soberania territorial dos Estados nacionais. A soberania representa o valor de maior hierarquia nesse modo de compreender a ordem internacional. No entanto, como proposto por Bull (2002), assim como a soberania, a proteção da vida é um valor básico encontrado no interior da ordem social proporcionada por esses mesmos Estados.

A afirmação teórica da coexistência de uma ordem territorial soberana com a proteção da vida humana, como fundamentos de um ordenamento normativo internacional, parece encontrar similaridade com a existência de uma concentração da vacinação em alguns Estados desenvolvedores, acompanhada da distribuição para aliados estratégicos desse grupo. Como os mapas evidenciam, ainda que exista uma demanda global pela vacina, sua oferta ocorre de modo concentrado em torno de Estados Unidos, Inglaterra, Rússia e China, mais Canadá, Qatar e Israel (Figura 2.3). 
Figura 2.3 - Vacinas administradas para cada 100 pessoas - 23/12/2020

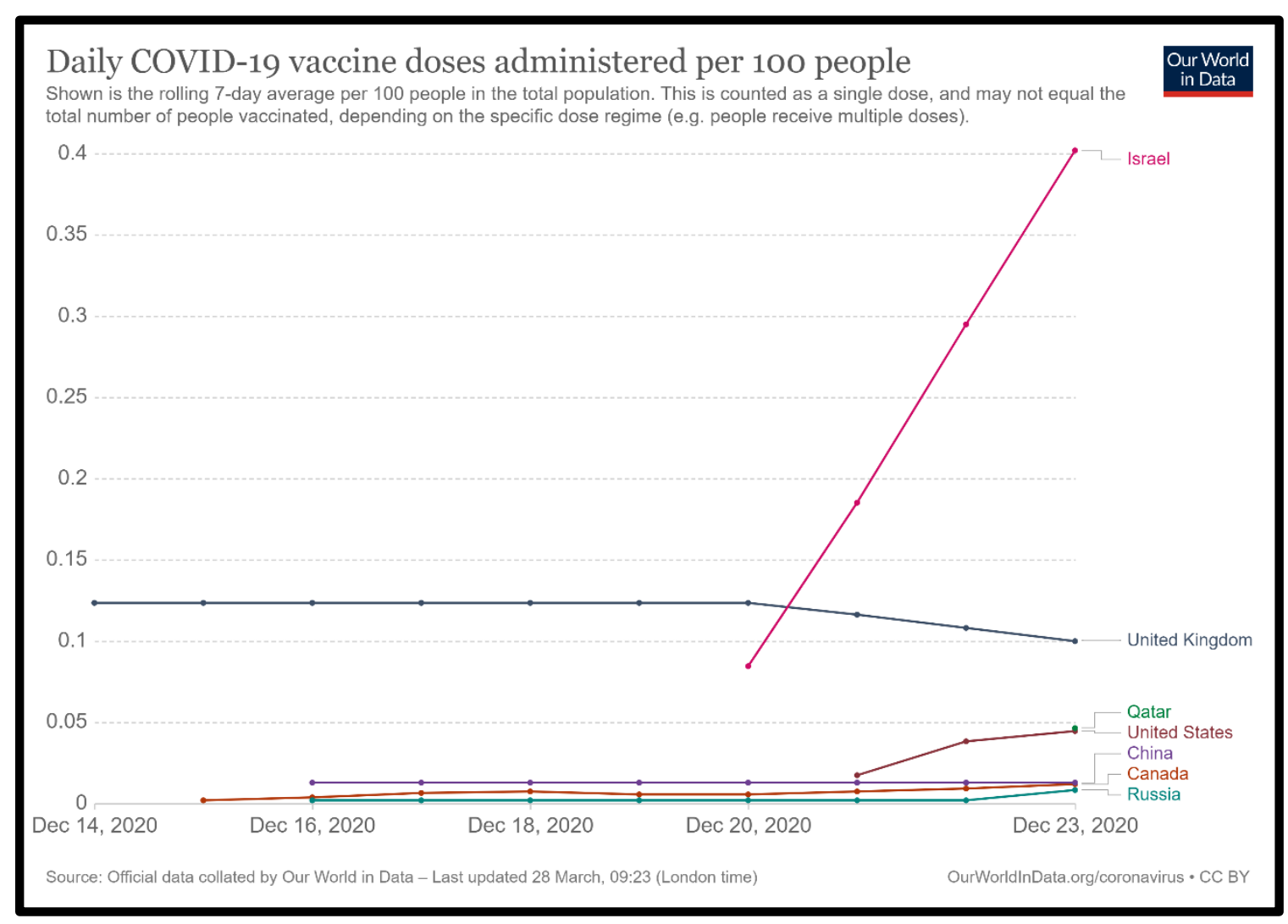

Fonte: RITCHIE, Hannah, et al, 2020.

De outro lado, a Figura 2.4 apresenta uma distribuição global de vacinas, liderada pela Covax Facility, concentrada na porção central do continente africano, no Oriente Médio, no Sudeste Asiático e alguns países da América do Sul. A Covax Facility é uma iniciativa coordenada pela OMS, em conjunto com a Coalizão para Promoção de Inovações em prol da Preparação para Epidemias (CEPI), a Aliança Mundial para Vacinas e Imunização (Gavi) e o Fundo de Emergência Internacional das Nações Unidas para a Infância (Unicef). O objetivo do grupo é proporcionar uma distribuição justa e equitativa das vacinas para cada país e, com isso, encerrar a fase aguda da pandemia ao final de $2021^{11}$.

11 As páginas oficiais da Covax Facility são: https://www.who.int/initiatives/actaccelerator/covax; https://cepi.net/; https://www.gavi.org/covax-facility; https://www.unicef.org/supply/covax-ensuring-global-equitable-access-covid-19-vaccines Acesso em 21 set 2021. 
O mapa apresentado na Figura 2.4 representa o perfil de distribuição das vacinas oferecidas pela Covax Facility. Ao contrário de uma lógica vertical soberanista concentrada nos países desenvolvedores, nota-se um perfil horizontal solidarista e, com exceção da China e da Índia, concentrado em porções do espaço geográfico marcadas por vazios em relação ao recebimento de vacinas, demonstrados nas Figuras 2.1 e 2.2. Caso sobrepostos, os mapas das Figuras $2.1,2.2$ e 2.4 indicariam um grau de complementaridade significativo a ser investigado.

Figura 2.4 - Covax Facility - 15/02/2021

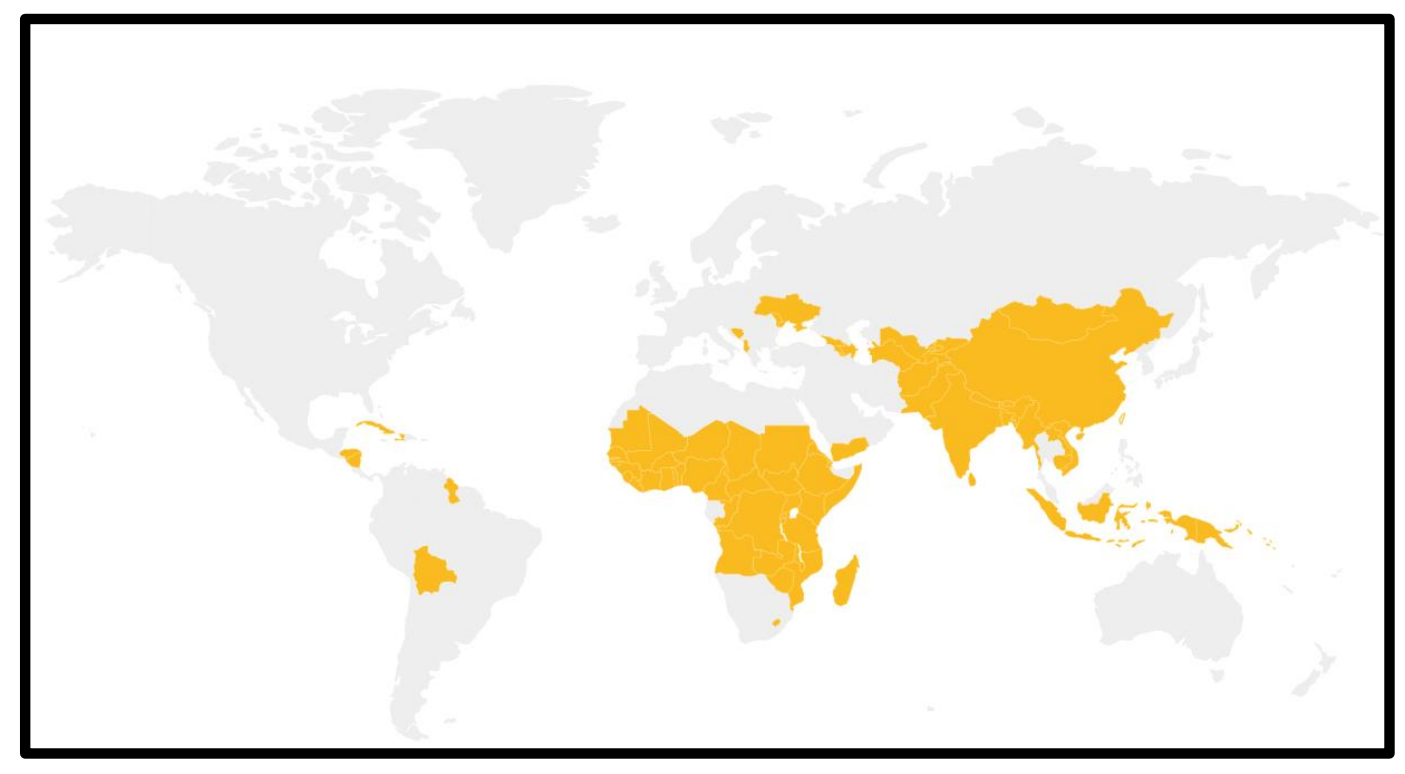

Fonte: Disponível em:https://www.gavi.org/programmes-impact/country-hub. Acesso em 21 set 2021.

Essa complementaridade ou coexistência entre uma lógica vertical soberanista, concentrada nos países desenvolvedores, e uma lógica horizontal solidarista, encontrada em países sem acesso ao imunizante, parece possuir ressonância na tese defendida pela Escola Inglesa de Relações Internacionais. Os teóricos da ordem internacional apontam para a existência de dois tipos de ordem: uma primeira, já apresentada, pautada em requisitos mínimos e 
centrada na soberania territorial e uma segunda, mais densa, na qual os direitos humanos são prioritários. O próprio Hedley Bull sugere o binômio entre a ordem e a justiça, como representativo desses dois modelos de ordem.

Em linhas gerais, o argumento elaborado pela Escola Inglesa indica a coexistência de dois modelos normativos de ordem internacional: o primeiro soberanista, centrado na soberania e na autodeterminação, e o segundo solidarista, orientado em torno dos direitos humanos e do indivíduo. Como demonstra Dunne (2008, p. 274), "in a pluralist international Society, the institucional framework is geared toward the liberty of states and the maintenance of order among them".

A coexistência de duas esferas normativas internacionais, que possuem hierarquias de valores distintos, procura demonstrar que uma ordem formal pura, apenas estruturada pela lógica soberanista, acaba sendo contraposta a fatos internacionais pautados por uma lógica inversa, fundamentada na defesa do indivíduo e dos direitos humanos.

Diante desse desafio teórico em torno da natureza da ordem nas relações internacionais, passou a existir um debate na Escola Inglesa entre o pluralismo e o solidarismo: "For Much of the post-cold war period, the normative debate within the English School fractured along a pluralist/solidarist divide" (DUNNE, 2008 , p. 275). Esse debate criou dentro da escola linhas de entendimento sobre como o modelo de ordem internacional pode ser entendido.

A coexistência de fatos internacionais que evidenciam fórmulas solidaristas, com a permanência e perenidade da lógica soberanista nesse mesmo sistema internacional, levou Hedley Bull a estabelecer uma hierarquia entre ambas as dimensões normativas. No entendimento do autor, o solidarismo é uma extensão da ordem soberanista. Não se trata de substituição, nem de uma transformação do sistema de Estados soberanos e autodeterminados em um sistema baseado no indivíduo e nos direitos humanos, mas, sim, de uma extensão desse sistema, derivada de ações humanitárias coordenadas pelos Estados (DUNNE, 2008).

Em vias de síntese, a pergunta que orientou esta seção estava em 
perseguir uma linha de raciocínio que identificasse o perfil de ordem internacional que podia ser inferido da combinação dos mapas de distribuição de vacinas, tanto dos Estados desenvolvedores quanto da Covax Facility. Essa complementaridade, entre uma distribuição concentrada e vertical de vacinas nos países desenvolvidos e uma distribuição horizontal em países em desenvolvimento, parece ter sintonia com o entendimento teórico de Bull.

Enfim, o que merece destaque é o modo como o espaço geográfico estabelece os limites entre a zona de distribuição vertical: Estados Unidos, Inglaterra, Rússia e China; e a zona de distribuição horizontal, formada prioritariamente pela África Subsaariana, África Central, Chifre da África, Ásia Meridional, Ásia Central e Sudeste Asiático.

\section{CONSIDERAÇÕES}

Este ensaio teórico teve por objetivo sugerir uma aproximação entre a geografia e a Escola Inglesa de Relações Internacionais. Esse exercício interdisciplinar foi aplicado à formulação de uma hipótese, que procurou explicar como a dimensão normativa internacional condicionou a distribuição de vacinas contra Covid-19 no primeiro mês de vacinação.

O que identificamos como potencial linha de trabalho é a existência de uma zona densa e de distribuição soberanista, concentrada em Estados Unidos, Rússia, China e Inglaterra, e uma zona dispersa e solidarista, formada majoritariamente pelas porções meridional, central e do Sudeste do continente asiático, somadas às porções subsaarianas desse continente.

A pesquisa desenvolvida foi de caráter exploratório e, portanto, merece sugestões de encaminhamento futuro: (i) para uma pesquisa de maior alcance bibliográfico sobre os modelos de distribuição de vacinas, indicamos elaborar uma bibliometria sobre os estudos já produzidos sobre o assunto; (ii) em geral, o entendimento da distribuição de recursos, como é o caso das vacinas, pode ser pautado pelos modelos de comércio internacional baseados em oferta e 
demanda, mas, como recorte de pesquisa, indicamos restringir o levantamento bibliográfico a modelos geopolíticos de análise; (iii) a fim de garantir a confiabilidade dos dados globais expostos na plataforma da OMS, sugerimos pesquisar as fontes originais nos Estados de maior interesse; (iv) para uma pesquisa avançada, indicamos elaborar estudos de caso dos países-chave, como Estados Unidos, Rússia, China e Inglaterra, pois cada um deles elaborou políticas de incentivo à pesquisa, bem como já possuía capacidade industrial de fabricação de vacinas.

Em suma, o desenho da pesquisa exploratória foi elaborado mantendo o nível de análise do sistema internacional. Procuramos manter toda a investigação nessa escala de observação. Nesse sentido, as políticas públicas dos países citados, as capacidades industriais de fabricação, os laboratórios privados e os convênios entre Estado e setor privado são dimensões que devem ser incluídas em uma pesquisa orientada para um nível de análise distinto. Tratase de dimensões complementares, ainda que representem modelos de pesquisa independentes.

\section{REFERÊNCIAS}

BULL, Hedley. A sociedade anárquica: um estudo da ordem na política mundial. São Paulo: UnB, 2002.

BERVIAN, P. A.; CERVO, A. L.; SILVA, R. Metodologia Científica. $6^{a}$ ed. São. Paulo: Pearson Prentice Hall, 2007.

Dunne, Tim. The English School. (In) REUS-SMITH, C. SINDAL, D. The Oxford Handbook of

International Relations. New York: Oxford University Press. 2008. FROTA, A. F. M. A O

Brasil no Conselho de Segurança das Nações Unidas nos anos 1990: uma interpretação racionalista. 100f. UFPR, Curitiba, 2013. Disponível

em: <https://acervodigital.ufpr.br/bitstream/handle/1884/41031/R\%20-\%20D\%20-

$\% 20$ ANDRE $\% 20$ FRANCISCO $\% 20$ MATSUNO $\% 20$ DA $\% 20$ FROTA.pdf? sequence =2\&isAllowed $=y>$. Acesso em 13 abr.2021.

JARDEWESKI, C.; FROTA, A.F.M. O espaço geográfico global. Curitiba: Intersaberes, 2019. SOARES, S. V., Picolli, I. R. A., \& Casagrande, J. L. (2018). Pesquisa Bibliográfica, Pesquisa Bibliométrica, Artigo de Revisão e Ensaio Teórico em Administração e Contabilidade. Administração: Ensino E Pesquisa, 19(2), 308-339.

https://doi.org/10.13058/raep.2018.v19n2.970

\section{OBRAS CONSULTADAS}

JUBILUT, Liliana Lyra. Não intervenção e legitimidade internacional. São Paulo: Saraiva, 
2010.

NOGUEIRA, João Pontes; MESSARI, Nizar. Teoria das relações internacionais: correntes e debates. Rio de Janeiro: Elsevier, 2005.

SARAIVA, José Flávio Sombra. Revisitando a escola inglesa. Revista Brasileira de Política

Internacional, v. 49, n. 1, p. 131-138, 2006.

SMITH, Steve. Is the truth out there?: eight questions about international order. In: PAUL, Thazha Varkey; HALL, John. A. (Orgs.). International order and the future of world politics. Cambridge: Cambridge University, 1999.

SOUZA, Emerson Maione de. A contribuição e o desenvolvimento da escola inglesa de relações internacionais. 156 p. Dissertação (Mestrado em Relações Internacionais) - Instituto de Relações Internacionais, Pontifícia Universidade Católica do Rio de Janeiro. Rio de Janeiro, $2003 . \quad$ Disponível em: http://www2.dbd.pucrio.br/pergamum/biblioteca/php/mostrateses.php?open=1\&arqtese=0114308_03_Indice.html. Acesso em 24/12/2012.

SOUZA, Emerson Maione de. A escola Inglesa no pós-Guerra Fria: fechamento, tradicionalismo ou inovação? Cena Internacional, v. 8, n. 2, p 29-62. 2006.

SOUZA, Emerson Maione de. Re-evaluating the contribution and legacy of Hedley Bull. Brazilian Political Science Review. Rio de Janeiro, v. 3, 2008. Disponível em: <http://socialsciences.scielo.org/scielo.php?script=sci_arttext\&pid=S1981-

$38212008000100005 \&$ Ing $=$ en\&nrm=iso $>$. Acesso em 14/11/2013.

SOUZA, Emerson Maione de. Ordem e justiça na sociedade internacional pós- 11 de Setembro. Revista Brasileira de Política Internacional. Brasília, v. 52, n. 1, jun. 2009. Disponível em:http://ref.scielo.org/s3fxnc. Acesso em: 28/12/2012.

WIGHT, Martin. An anathomy of international thought. Review of International Studies, $v$. 13, n. 3, p. 221-227, Cambridge University, 1987.

WIGHT, Martin. A política do poder. Brasília: UnB, 1985.

WIGHT, Martin. Western values in international relations. In: BUTTERFIELD, Herbert; WIGHT, Martin. (Orgs.). Diplomatic investigations: essays in the theory of international politics. London: Allen and Unwin, 1966.

WIGHT, Martin. International theory: the three traditions. WIGHT, Gabriele; PORTER, Brian (Eds.). London: Leicester University, 1991.

RONNFELDT, Carsten F. Beyond a Pluralist Conception of International Society? A Case Study on the International Response to the Conflict in BosniaHercegovina. Cooperation and Conflict, vol. 34, n02, 1999

REUS-SMITH, C. SINDAL, D. The Oxford Handbook of International Relations. New York: Oxford University Press. 2008. 


\section{CAPÍTULO 3 - A PARTICIPAÇÃO POPULAR POR MEIO DE MECANISMOS DEMOCRÁTICOS DE JUSTIÇA ESPACIAL EM TEMPOS DE PANDEMIA}

RODOLFO DOS SANTOS SILVA ${ }^{12}$

\section{INTRODUÇÃO}

Diante de um modelo de ocupação do espaço urbano que favorece as grandes corporações industriais e comerciais, do mercado financeiro e do mercado imobiliário, dificultando o acesso à moradia aos trabalhadores nas proximidades de seu local de trabalho, torna-se imprescindível a existência de mecanismos de mobilização da população como forma de evitar que os recursos públicos sejam definidos apenas por alguns membros da classe política e econômica. Implementado inicialmente em Porto Alegre, há mais de três

12 Bacharel em Ciências Econômicas pela Faculdade Católica de Administração e Economia (1995). Licenciado em Matemática pela UTFPR. Pós-graduado em Magistério Superior pelo Instituto Brasileiro de Pós-Graduação e Extensão (1997). Mestre em Tecnologia pela UTFPR (2001). Doutor em Educação pela UFPR (2017). Atualmente, está concluindo o Curso de Formação Pedagógica em História (Uninter). Possui experiência como professor do Ensino Fundamental e Médio, atuando por muitos anos na rede estadual de ensino. Foi gestor público entre os anos de 2003 e 2005. É professor de ensino superior no Centro Universitário Internacional Uninter. É coordenador da linha de pesquisa Movimentos Sociais, Estado e Cidadania e do projeto de pesquisa Participação Popular na Determinação do Orçamento Público e Economia Solidária. Tem experiência na área de educação, com ênfase em educação e tecnologia. Como economista, atua na assessoria de projetos em âmbito público e privado. Possui formação e experiência e atua com os seguintes temas: economia política; geografia política; políticas públicas; geografia urbana; desenvolvimento econômico; economia solidária; conjuntura econômica; sustentabilidade e desenvolvimento; planejamento urbano; metropolização; empreendedorismo; comércio e serviços; marketing; e orçamento público. É autor e coautor de diversos livros, assim como de vários artigos sobre as temáticas mencionadas. 
décadas, surgiu como forma de dar vez e voz à população do município o orçamento participativo.

O orçamento participativo foi disseminado por governos populares como boa prática de gestão e se transformou em uma ferramenta de mobilização da população nas decisões sobre a aplicação do orçamento público frente às políticas neoliberais de abertura de espaços no setor público para a intervenção do setor privado. Exemplos dessa intervenção são as parcerias entre o setor público e o setor privado, assim como as operações urbanas realizadas de forma consorciada que visam a garantir a transferência de recursos públicos para a iniciativa privada.

Para discutir a participação da população na defesa de seus interesses por meio de mecanismos democráticos de intervenção popular nas decisões sobre a aplicação, gestão e transformação do espaço urbano e de justiça espacial existentes, utilizou-se a coleta de dados a partir das informações de contagem e estimativas populacionais do Censo Demográfico do Instituto Brasileiro de Geografia e Estatística (IBGE), bem como o estudo de documentos e entrevistas com pessoas consideradas fontes primárias, transcrições, relatórios originais de eventos, pesquisas em documentos iconográficos, livros, jornais, revistas, periódicos, artigos, monografias, dissertações e teses, fontes em meio digital (internet) e dados produzidos pelo Observatório das Metrópoles, órgãos estaduais de estatística e economia e secretarias municipais nos estados do Paraná e Rio Grande do Sul.

Como problemática, discute-se de que forma a mobilização popular e o orçamento participativo contribuíram para a transformação do espaço urbano e por que tais experiências, que passaram a ser disseminadas como boas práticas de gestão dos recursos públicos, se mantêm ou foram gradual ou repentinamente abandonadas nos municípios estudados, que integram regiões metropolitanas do Sul do Brasil. Para o desenvolvimento da pesquisa, foram estabelecidas como hipóteses: (i) se o orçamento participativo implementado como modelo de gestão contribuiu para promover alterações no espaço urbano, 
minimizando os impactos gerados pela reestruturação desses espaços nas cidades selecionadas das Regiões Metropolitanas de Curitiba, Porto Alegre, Maringá e Chapecó; (ii) se essas cidades, que passaram por gestões públicas que aplicaram o orçamento participativo, proporcionaram à população mecanismos de participação popular que poderiam, de certa forma, alterar e alteraram a configuração do espaço urbano nos municípios de Porto Alegre, Pinhais, Maringá e Chapecó; (iii) se a continuidade ou abandono de tal prática, gradual ou repentinamente, nos municípios estudados foi motivado pelo processo neoliberal de ajuste espacial, conforme os interesses do mercado imobiliário e financeiro; (iv) se e como a pandemia de Covid-19 acentuou os processos decisórios nos municípios estudados.

Para chegar aos resultados esperados, destaca-se que os municípios escolhidos possuem forte influência sobre os demais de suas regiões metropolitanas e todos passam por uma nova divisão internacional do trabalho, que altera a dinâmica de produção do espaço urbano, objetivando atender a diferentes interesses econômicos, políticos, sociais e geográficos.

\section{A REESTRUTURAÇÃO DO ESPAÇO URBANO E A INJUSTIÇA TERRITORIAL}

Em um período de relevantes alternâncias na composição da dinâmica das grandes metrópoles, houve uma reestruturação e valorização do espaço urbano, atreladas a um processo de segregação residencial e alocação dos investimentos públicos que vem agravando ainda mais os problemas relacionados à posse da terra e injustiça espacial. Discute-se como o ser humano ocupa seus espaços na grande metrópole em um modelo de sociedade que, de forma legalizada, cria barreiras invisíveis para manter distante uma vizinhança indesejada, como os bairros ou localidades que acolhem as populações mais pobres. No entendimento de Lefebvre (2001), as injustiças espaciais são marcadas pelo interesse das grandes e poderosas corporações, que possuem como principal objetivo a 
obtenção de lucros sem se importar com os custos sociais e ambientais que tais interesses possam atingir.

Para Harvey (2005), a decisão sobre o pensar o espaço nas grandes metrópoles é constituída por um conjunto complexo de forças mobilizadoras compostas por diferentes grupos sociais. Quem toma a iniciativa de conduzir esse processo são os grupos de poder relacionados ao comércio, aos financistas, aos líderes empresariais e incorporadores imobiliários que mantêm sob seus domínios a máquina capitalista do desenvolvimento. Apesar dos interesses divergentes, os demais membros da sociedade local, com capacidade de influenciar e se tornar agentes de transformação na produção do espaço urbano, são as instituições religiosas e educacionais, "as organizações sindicais locais (em particular, do setor da construção civil), assim como os partidos políticos, os movimentos sindicais e os aparelhos estatais locais (que são múltiplos e frequentemente heterogêneos)" (HARVEY, 2005, p.171).

Garbossa e Silva (2016) afirmam que a estrutura de produção do espaço urbano nas grandes metrópoles é composta por uma série de processos sociais que influenciam a determinação das funções, das formas espaciais e cuja materialização e organização espacial são caracterizadas por diversas centralidades. Essa composição é marcada por espaços de produção, de comércio e de moradia, que favorecem o surgimento de espaços segregados que intensificam as desigualdades sociais. Para tais autores, mesmo que a democracia possibilite um maior compartilhamento do poder entre as diferentes classes sociais, é necessário que os grupos sociais que compõem a maioria dos habitantes da metrópole façam valer seus direitos frente aos interesses dos grandes grupos financistas/rentistas e do mercado imobiliário.

Maricato (2005) assevera que a concentração de grandes contingentes populacionais nas metrópoles faz com que o preço da terra não esteja relacionado apenas às questões de oferta e demanda, mas também à escassez da terra urbana bem localizada e com infraestrutura. No entendimento dessa autora, os modelos de planejamento implementados nas grandes cidades são 
moldados na lógica do capitalismo, cujo ideal é destinar as áreas de maior infraestrutura aos grupos de incorporadores e produtores imobiliários que produzirão bairros para grupos de maior poder econômico, amparados em uma legislação urbana de zoneamento, que designará as demais áreas para moradia, produção e consumo dos demais grupos da sociedade.

Além da preocupação com a moradia, grande parte dos habitantes das metrópoles se depara com dificuldades para encontrar trabalho formal e está exposta a conviver diariamente com outros problemas, como a violência, a exclusão e a segregação residencial. Dessa forma, o espaço urbano das metrópoles continua sendo um espaço de reprodução da força de trabalho e, cada vez mais, de injustiças espaciais. Harvey (2009) identifica na intensidade de acumulação de capital e no esgotamento de uma das fontes de expansão dos investimentos a necessidade dos grandes grupos econômicos capitalistas de encontrar novas maneiras para ampliar seus excedentes. Nesse sentido, para esse autor, há uma pressão sobre o Estado, para que utilize suas políticas econômicas para a multiplicação desse capital excedente.

Para Carlos (2007), o uso do Estado em favor da multiplicação dos recursos do grande capital tornou-se mais efetivo a partir da utilização da máquina midiática neoliberal para criticar a estrutura estatal, sua ineficiência, sua burocracia e seu alto custo de manutenção. Se não bastasse tudo isso, todo aparato neoliberal utiliza um discurso que defende o fim da interferência do Estado no mundo dos negócios, ressaltando que essas medidas seriam o maior triunfo do capitalismo globalizado nos países. Essas medidas, colocadas em prática, tornaram o Estado mais flexível, mais eficiente e mais habilidoso nas concessões realizadas ao grande capital, mas menos flexível e tolerante no campo das políticas sociais e reivindicações da classe trabalhadora. Assumida pela classe produtora brasileira, essa preleção da globalização e do neoliberalismo arraigou no país a desigualdade e a segregação espacial.

O resultado da reestruturação econômica e social provocadas por essa dinâmica de desigualdade e segregação espacial atende aos interesses dos 
grandes grupos nacionais e internacionais que visam a desqualificar as propostas resultantes de iniciativas que possam servir como alternativas a esse modelo excludente colocado em prática pelos gestores das grandes cidades. Esse modelo perverso pode ser percebido na quantidade de pessoas que são colocadas a viver à margem de grande parte dos benefícios gerados pela metrópole. Nesse sentido, Harvey (2005) questiona o discurso de que o Estado vem perdendo importância política no contexto neoliberal, com tendências ao desaparecimento. Para esse autor, se o Estado perde importância, não o é na formulação de políticas que favorecem o processo de internacionalização do capital e de globalização dos fluxos financeiros e/ou na repressão das organizações sindicais de trabalhadores e movimentos sociais.

Segundo Santos (2008), a globalização impõe aos Estados mais pobres a subserviência aos mais ricos, propositores de uma nova ordem econômica, social e política que valoriza o grande capital e deprecia as tradições e culturas locais. Apesar disso, entende que existe a possibilidade de que as localidades se fortaleçam coletivamente por meio da união de toda a sociedade civil em torno de interesses comuns. Esses interesses tendem a garantir aos que necessitam de melhores condições de vida, como infraestrutura básica, saneamento, emprego e moradia, assim como àqueles que buscam investimentos ou isenções fiscais ao setor produtivo e de serviços, tudo isso testemunhado pelas instituições e organizações e pela mídia local.

O que se vivenciou na última década do século passado e nesses primeiros anos do século XXI foi a colocação em prática por parte de governos neoliberais de um conjunto de medidas que visaram a ampliar a participação do mercado financeiro, imobiliário e rentista na destinação dos investimentos públicos. Além disso, avançou-se na pauta de redução dos direitos de proteção aos trabalhadores e flexibilização das leis de exploração da terra e do uso do solo, reduzindo custos de produção, favorecendo ganhos maiores para os produtores e exportadores de bens e serviços do agronegócio. Essa minimização da presença do Estado também facilitou e vem facilitando a remessa de dinheiro 
entre diferentes corporações de um Estado e outro, ampliando as vantagens da remessa de lucros e ganhos do capital internacional.

No entendimento de Maricato (2015), nem tudo foi tão ruim no capitalismo brasileiro, sendo possível considerar algumas melhorias nos indicadores relativos às metrópoles, especificamente nas áreas de saúde, educação e saneamento básico, porém, com a expansão do discurso neoliberal e da globalização, o que mais cresceu nas cidades, especialmente nas grandes, foi o número de pessoas morando em assentamentos irregulares e precários, resultado negativo causado pelo alto custo do uso do solo urbano, pelo aumento do desemprego e das condições precárias do trabalho informal, pela redução dos gastos governamentais com políticas sociais e pela queda no desenvolvimento econômico.

Silva (2017) destaca positivamente as contribuições dos movimentos sociais, em especial, o Movimento Nacional pela Participação Popular na Constituinte e o Movimento pela Reforma Urbana. Esses movimentos exerceram uma forte pressão sobre os parlamentares constituintes para aprovação na Constituição Federal (CF) de artigos que contemplassem a participação democrática da população na elaboração dos Planos Diretores, na aplicação e fiscalização dos recursos públicos. Para esse autor, o art. 182 é um dos poucos que trata especificamente dos problemas das cidades, mas de suma importância para que a população possa acompanhar mais de perto o processo de democratização onde vive. Portanto, a Lei Orçamentária Anual (LOA), a Lei de Diretrizes Orçamentárias (LDO), o Plano Plurianual (PPA) e o orçamento participativo se tornaram instrumentos imprescindíveis de fiscalização e participação da população no processo decisório do município.

O orçamento participativo é um modelo de gestão pública, colocado em prática pela Prefeitura Municipal de Porto Alegre com o objetivo de dar maior transparência às decisões sobre a peça orçamentária. Na definição de Lüchmann (2014), Fedozzi (2008) e Wampler (2008), é um processo que envolve a participação da população no debate sobre a destinação dos recursos públicos, 
as obras e serviços a ser executados pela gestão municipal. Esse processo ocorre em todas as regiões da cidade e nas plenárias temáticas, em que a população decide sobre suas prioridades orçamentárias e escolhe os seus representantes, que atuarão como delegados nos fóruns regionais e temáticos. Nesse contexto, desde a primeira experiência (implementada em uma metrópole como Porto Alegre, RS), o orçamento participativo vem se constituindo como um importante instrumento de gestão pública, com possibilidades para a interferência da população no planejamento e na aplicação dos recursos municipais.

De acordo com Pont (2000), Pires (2001), Fedozzi (2002), Brandão (2003), Gonçalves (2005) e Avritzer (2012), a partir do fim dos anos 1980 e início dos anos 1990, as experiências de orçamentos participativos em governos que se estabeleceram como Frente Popular, formados por políticos do Partido dos Trabalhadores (PT), Partido Comunista do Brasil (PCdoB) e Partido Socialista Brasileiro (PSB), abriram espaços em diversas prefeituras do país para a participação popular nas decisões sobre a aplicação das receitas e despesas públicas, surgindo assim, diante da democracia representativa, a democracia participativa direta.

A experiência de Porto Alegre é a primeira localizada em uma região metropolitana. Instituída, em 1973, a Região Metropolitana de Porto Alegre foi criada com as Regiões Metropolitanas de Belém, Fortaleza, Recife, Salvador, Belo Horizonte, São Paulo e Curitiba, estabelecidas pela Lei Complementar no 14, de 8 de junho de 1973, que teve em 1974 incluída a Região Metropolitana do Rio de Janeiro pela Lei Complementar no 20, de $1^{0}$ de julho de 1974, correspondendo aos 12 espaços metropolitanos identificados pelo Estudo de Influência de Cidades e reconhecidos pelo IBGE.

O orçamento participativo, na forma como foi implantado em Porto Alegre, representou um passo importante de aperfeiçoamento da democracia na política. É uma forma de incluir nas decisões sobre finanças e políticas públicas a população organizada e a sociedade civil, que assumem um papel ativo, deixando de ser apenas espectadores, mesmo conflitando com interesses 
estabelecidos por parlamentares e o Poder Executivo, diante do que pode ser visto por alguns autores, como Avritzer (2012), Gonçalves (2005) e Pires (2001), como radicalização da democracia; para eles, a democracia participativa passa a ser um instrumento para atingir da melhor forma possível a alocação dos recursos públicos, abrindo espaços para a população exercer o seu direto e o seu dever na destinação dos recursos governamentais. Assim, o orçamento participativo resgata a ideia de que o indivíduo é sujeito, fazendo parte de uma sociedade regida por normas e regras, que também lhe pertence e pode por ele ser transformada. Desde 1989, em Porto Alegre, conforme Gonçalves (2005), Pires (2001) e Fedozzi (2002), milhares de pessoas reúnem-se em 16 plenárias regionais e seis plenárias temáticas, em consecutivas reuniões intermediárias, com o objetivo de apresentar demandas, analisar e escolher prioridades de acordo com o Regimento do Orçamento Participativo.

\begin{abstract}
A II Conferência das Nações Unidas sobre os Assentamentos Humanos (Habitat II), ocorrida em Istambul em junho de 1996, reconheceu o orçamento participativo como uma das 40 melhores práticas do mundo envolvendo a participação popular. A partir dessa conferência, instituições multilaterais, como a Organização das Nações Unidas (ONU) e o Banco Mundial, contribuíram para sua expansão como um modelo de democracia capaz de transformar a sociedade. Os Fóruns Sociais Mundiais (FSM), em 2001, 2002 e 2003, realizados primeiramente em Porto Alegre, também deram sua contribuição para tornar o orçamento participativo mais conhecido. Em 2004, o FSM aconteceu em Mumbai, na Índia. Em 2005, Porto Alegre o sediou novamente, quando se optou por não mais realizar os próximos eventos na capital do Rio Grande do Sul e, sim, em outras cidades de outros países e de diferentes continentes.
\end{abstract}

Para Porto de Oliveira (2016), o impulso para a expansão do orçamento participativo pelo mundo deu-se pelo FSM, que fez chegar ao conhecimento de vários representantes de diversas cidades do mundo essa prática, principalmente devido à sua radicalização das formas democráticas de decisão orçamentária. Por meio desse evento, foi possível às delegações internacionais visitar os bairros e suas plenárias de participação do orçamento participativo, assim como o contato direto dessas representações com os membros das comunidades locais e sua empolgação com a proposta, até então, inovadora de 
propor, discutir, elaborar, decidir e fiscalizar a aplicação dos recursos públicos. Para esse autor, também foi possível compreender mais sobre o orçamento participativo, com a participação em oficinas realizadas no fórum sobre a temática. Além disso, uma série de publicações de livros, panfletos, cartilhas e materiais de divulgação em diferentes línguas sobre o tema facilitou aos estrangeiros compreender melhor a proposta. Após os fóruns, muitos dos participantes e propositores do orçamento participativo em Porto Alegre passaram a percorrer o mundo para divulgar essa proposta de inserção e participação democrática da população porto-alegrense.

A eficiência do marketing do orçamento participativo realizado pela Prefeitura Municipal de Porto Alegre tornou possível que, em pouco tempo, diversos países tomassem a iniciativa de implementá-lo, conforme destacam Sintomer; Herzberg; Rocke (2012). Para esses autores, já em 2000, várias importantes cidades europeias haviam incluído o orçamento participativo como uma de suas ferramentas decisórias sobre a aplicação dos recursos públicos. Barcelona, Berlim, Paris, Roma e Lisboa adotaram um modelo de participação democrática muito próximo do orçamento participativo de Porto Alegre. Além disso, cidades de outros países europeus, como Polônia, implementaram o modelo de Porto Alegre com apoio governamental. Países africanos, como Zâmbia, Zimbábue, Moçambique, Quênia, Congo, África do Sul e Camarões, também desenvolveram práticas similares, motivados pela experiência da capital gaúcha. Os países latino-americanos, há mais tempo e em maior quantidade, possuem modelos de orçamento participativo que são próximos do utilizado em Porto Alegre, inclusive estabelecidos por leis nacionais, como no Peru, Uruguai, Venezuela, Equador e República Dominicana.

As boas práticas de gestão dos recursos públicos por meio do orçamento participativo, onde foram implementadas, foram utilizadas como ferramentas para reduzir os impactos das desigualdades sociais estabelecidas em sua dimensão espacial e promover, mediante a gestão pública e democrática, a justiça territorial. Nas cidades foco desta pesquisa, o orçamento participativo obteve grande aceitação, por constituir um meio de transmissão de 
representatividade por intermédio de um instrumento democrático e confiável dos anseios das populações excluídas de qualquer debate sobre a destinação das verbas públicas.

\section{AS EXPERIÊNCIAS DE DEMOCRACIA PARTICIPATIVA NAS METRÓPOLES DO SUL DO BRASIL}

Pelo fato de, na escala global, as metrópoles possuírem papel fundamental por se caracterizarem por diferenciações socioespaciais, econômicas e políticas que as incluem entre aquelas que recebem os maiores investimentos, instrumentos como o orçamento participativo podem garantir aos grupos de pessoas, aos movimentos sociais e às organizações não governamentais o poder de influenciar a alocação dos investimentos públicos realizados e modificar as condições de moradia na periferia de seus municípios. Ao terem suas demandas por regularização fundiária, habitação ou loteamentos para habitação, asfalto, calçadas, praças e controle das enchentes aprovadas nas audiências públicas, assembleias ou plenárias temáticas e executadas, é possível a transformação do espaço urbano nessas realidades municipais.

Se o orçamento participativo se tornou uma realidade em muitos municípios das regiões metropolitanas em todo o país, o mesmo não ocorreu em âmbito metropolitano. Diante da utilização dos lineamentos teóricos da geografia, foi possível verificar como um mecanismo de gestão do orçamento público pode contribuir para melhorar a qualidade de vida da população e transformar a realidade daqueles que vivem nas cidades. Esta pesquisa constatou que, apesar de os municípios estarem numa posição geográfica de forte influência em suas regiões metropolitanas, a prática do orçamento participativo não se constituiu como instrumento de gestão conjunto das cidades que compõem esse espaço geográfico. 
Conforme Silva (2017), apesar de a experiência de Porto Alegre ter se expandido geograficamente para diferentes países, com a contribuição de instituições multilaterais, como o Banco Mundial e a ONU, a boa prática de gestão orçamentária não se tornou uma ferramenta de gestão dos recursos públicos em escala metropolitana. Das quatro regiões metropolitanas pesquisadas, apenas a de Porto Alegre iniciou um processo de discussão de uma integração orçamentária por meio dele, ainda assim sem concluir um processo de integração orçamentária entre todos os municípios. A Região Metropolitana de Curitiba também foi escolhida por ter municípios que afirmaram possuir o orçamento participativo como instrumento de participação democrática na gestão pública. Pinhais, entre 2008 e 2014, foi o único município dessa região metropolitana cujo Executivo municipal assumiu utilizar o instrumento.

Muitos dos municípios que integram a Região Metropolitana de Curitiba realizam os debates e as aplicações do orçamento público seguindo o que determina a CF de 1988, sem mencionar o orçamento participativo. A partir da regulamentação da CF, pelos dispositivos da Lei no 257/1971 (Estatuto da Cidade) e da Lei Complementar no 101 (Lei de Responsabilidade Fiscal), ficou estabelecida a obrigatoriedade da realização de debates, audiências e consultas públicas, com relação à aplicação dos recursos orçamentários por intermédio do PPA, da LDO e LOA. Tais mecanismos se estabeleceram como mecanismos obrigatórios de gestão pública, buscam assegurar a transparência e incentivam a participação popular nas audiências públicas sobre os mais diversos assuntos, como as medidas de impacto socioambiental e a elaboração dos planos de destinações orçamentárias.

Na Grande Curitiba, apenas três municípios utilizaram o termo "orçamento participativo" para a elaboração da LDO: Campo Largo, Pinhais e São José dos Pinhais. O município de Curitiba iniciou a utilização do termo no ano de 2014, para se referir ao processo de participação nas audiências públicas; em setembro de 2014, foi aprovado na Câmara Legislativa e sancionado pelo prefeito o projeto Vizinhança Participativa. Desde 2017, seguindo o art. 165, parágrafo 20 , da CF, 
que visa a estabelecer a cada ano as metas e prioridades da administração pública, relacionando o PPA, com previsão de quatro anos, e a LOA, que fixa as receitas e despesas anualmente, a Prefeitura de Curitiba vem realizando o programa Fala Curitiba.

O município de Campo Largo é um dos 29 municípios da Região Metropolitana de Curitiba, está localizado a $30 \mathrm{~km}$ da capital do estado e foi emancipado territorialmente de Curitiba em 2 de abril de 1870. Iniciado em março de 2009, seu orçamento participativo foi constituído a partir de uma coordenação geral e cinco coordenações regionais, com o acompanhamento de um técnico administrativo. Utilizando o discurso de inclusão social, passou a estimular a participação popular por meio de assembleias regionais (Bateias, Ferraria, Partênope, Itaqui e Centro), em que, por voto, eram realizadas as escolhas das prioridades estabelecidas por cada comunidade no município. Em outras 24 localidades, denominadas microrregiões e núcleos do orçamento participativo, também eram realizadas as plenárias.

Pesquisas iniciadas com o objetivo de identificar os motivos da descontinuidade do processo de participação popular na definição da aplicação dos recursos públicos por meio do orçamento participativo em Campo Largo deixaram transparecer que conflitos de poder e dificuldades de uma metodologia adequada foram as principais causas. Esses percalços levaram a Prefeitura Municipal de Campo Largo, a partir de 2016, a voltar ao modelo tradicional de decisão sobre a política orçamentária, o que consistia em elaborar as sugestões, discutir e aprovar em votações na Câmara de Vereadores as prioridades que o Executivo entendia como prioridades dos moradores. Agindo dessa forma, é possível perceber que o Executivo municipal entende como legítimas e suficientes a participação e decisão dos parlamentares na decisão sobre o orçamento municipal.

Pinhais foi outro município da Região Metropolitana de Curitiba que utilizou o termo "orçamento participativo" na destinação orçamentária. Desmembrado do município de Piraquara em 1992 e parte da extensão da mancha urbana do 
aglomerado metropolitano de Curitiba, é o menor município em extensão territorial do Paraná, com uma área de 60,92 km² e o mais próximo do centro da capital do estado $(8,9 \mathrm{~km})$. É considerado pelo IBGE como um município $100 \%$ urbano.

Em 2009, o Executivo municipal de Pinhais implantou um programa denominado Orçamento Participativo, primeiramente com a participação da comunidade votando nas principais demandas locais que seriam efetivadas pelo Executivo. Alguns meses após essa iniciativa, o Executivo local mudou a sua metodologia no processo de participação, imprimindo e consultando a partir de questionários a população dos bairros e depois anunciando em audiências públicas regionais as prioridades mais votadas e que deveriam ser executadas pela prefeitura.

A dinâmica do orçamento participativo de Pinhais constituiu-se da realização de duas audiências públicas, sempre entre abril e maio de cada ano, em regiões diferenciadas da cidade, sendo a primeira reunindo os bairros Atuba, Jardim Cláudia, Emiliano Perneta, Alphaville, Centro, Pineville, Estância Pinhais e Alto Tarumã e a segunda reunindo os bairros Weissópolis, Vargem Grande, Maria Antonieta, Jardim Amélia, Jardim Karla e Parque das Nascentes. Em uma primeira etapa, eram distribuídos os questionários contendo 20 itens (prioridades) a ser assinalados pelos moradores. Esses questionários poderiam figurar como demandas por parte da população. O Executivo municipal estabeleceu um item denominado "outros", que possibilitaria a indicação de outras prioridades. Os questionários eram distribuídos em escolas municipais, no prédio central da prefeitura, na portaria e nos gabinetes dos vereadores na Câmara Municipal, no setor de tributação da prefeitura, sendo disponibilizados também na página da internet da Prefeitura Municipal de Pinhais. Nas audiências públicas, eram demonstrados os resultados obtidos a partir dos questionários à população; após as exposições do prefeito e de órgãos governamentais convidados e algumas intervenções da população presente, a audiência era encerrada sem a ocorrência de nenhum processo de votação. 
Em 2015, foram recolhidos mais de 14.600 questionários e, entre as prioridades escolhidas pela população, foram apresentadas como demandas: segurança; mais médicos nas unidades de saúde; melhoria no atendimento à saúde; calçadas; e cursos profissionalizantes. Parques e praças e regularização de terrenos, que caracterizavam mudanças com relação à transformação do espaço urbano, não figuraram entre as cinco maiores prioridades. Apesar disso, o Executivo municipal, a partir de debates nas audiências públicas do orçamento participativo, promoveu o deslocamento de 655 famílias da beira do rio Atuba, nas proximidades da rua Victor Ferreira do Amaral, para o Conjunto Moradias Jerivá, que fazia parte do Programa de Aceleração do Crescimento (PAC) de Pinhais, para o qual foram construídas 634 casas, visando a beneficiar 1.383 famílias com moradias, titulação de imóveis e regularização fundiária. Algumas famílias ainda se mantêm resistentes e não concordaram em sair do local onde estão, à beira do rio Atuba e sujeitas a inundações.

Em Curitiba, a participação popular na discussão sobre a destinação dos recursos orçamentários também ocorreu durante as gestões municipais de 2004 e 2012, mediante audiências públicas. O Executivo municipal, entre 2004 e 2012, sem pretender abrir um processo decisório com participação popular na destinação dos recursos orçamentários e muito mais com a preocupação de cumprir as exigências legais da CF de 1988, do Estatuto da Cidade e da Lei de Responsabilidade Fiscal, realizou as audiências públicas orçamentárias com vistas à construção da LDO e da LOA em cada uma das nove regiões em que a capital está administrativamente subdividida.

As reuniões foram realizadas em duas etapas; na primeira etapa, a prefeitura, por meio de seus organismos e secretarias, apresentava à população as prioridades, definidas pelo próprio Executivo municipal, que iriam compor a LDO do ano seguinte. Depois, a LDO era encaminhada à Câmara Municipal, votada e seguia para a mesa do prefeito para ser sancionada. A partir de 2013, novas agremiações partidárias assumiram o controle político da Prefeitura de Curitiba e buscaram manter consultas públicas, uma em cada região 
administrativa da cidade, nas quais os cidadãos participavam por sugestões sobre a destinação dos recursos previstos para o orçamento do ano subsequente.

Sempre realizadas em março e abril, a série de consultas abria a possibilidade para a participação popular pelo encaminhamento de sugestões e questionamentos nas plenárias das audiências públicas, que, no ano de 2015, foram realizadas entre 15 e 25 de julho, por meio de redes sociais ou telefone. Com a participação de 5.845 pessoas ouvidas, foi montada a proposta para a composição de peça orçamentária contemplando, entre outros, as vias públicas $(20,07 \%)$, segurança $(16,39 \%)$, saúde $(10,54 \%)$, trânsito $(10,41 \%)$ e esporte e lazer (7,68\%). Também em julho, no dia 31, no Teatro Londrina do Memorial de Curitiba, foi realizada a Conferência do Orçamento Municipal, deixando claro o interesse da gestão municipal em fazer acontecer o orçamento participativo em Curitiba.

Conforme Maricato (2015), para tornar a regermanoalidade urbana mais justa e inclusiva, basta a utilização dos instrumentos já existentes; por exemplo, o IPTU, mesmo não sendo progressivo, poderia ser utilizado como forma de ampliar a arrecadação do município com cobranças mediante alíquotas diferenciadas para fazer justiça social.

\section{AS DECISÕES DO ORÇAMENTO E A PARTICIPAÇÃO POPULAR EM TEMPOS DE PANDEMIA}

Em 2019, a primeira experiência de democracia participativa de Porto Alegre completou 30 anos e, conforme visto anteriormente, ainda é persistente na população a identidade criada com iniciativas que deram resultados na elaboração da peça orçamentária. Apesar disso, o PT, um dos principais responsáveis pela implementação do orçamento participativo, se sentindo alvo de intensa campanha de destruição de sua reputação e de suas políticas sociais 
pela mídia, por outros partidos políticos e por grandes grupos empresariais - 0 que o levou a sair derrotado das eleições de 2016 -, não apresenta como uma de suas maiores bandeiras de campanha esse importante instrumento de participação democrática da população. As análises realizadas sobre o orçamento participativo como um instrumento de transformação do espaço urbano deixam claro que, se houver vontade política e um envolvimento da população, os recursos obtidos a partir do excedente de produção, alcançados pelas grandes cidades, poderão ser distribuídos espacialmente de forma democrática e justa.

Quando o primeiro caso de contaminação pelo novo coronavírus no Brasil foi identificado no final de fevereiro de 2020, o mundo já registrava muitas centenas de casos de covid-19. Em março, a primeira morte por vírus provocou a declaração de transmissão comunitária no país. Um ano depois, o Brasil já ultrapassava mais de 200.000 mortes e, em junho do mesmo ano, atingia 500.000 mortes. Além das incertezas sobre as diversas variantes do coronavírus no país, a demora das autoridades públicas em buscar soluções para o problema agravou as previsões, já pessimistas no início da pandemia, sobre o nível de emprego e elevação da pobreza.

Além de afetar o desempenho da economia do país, de acordo com a Prefeitura Municipal de Porto Alegre (2021), a pandemia interrompeu as atividades do orçamento participativo durante 2020 e 2021. A não realização das consultas, plenárias e reuniões do Conselho Municipal do Orçamento Participativo (COP), em razão da Covid-19, provocou mais dificuldades para que a população pudesse apresentar as suas demandas. Para 2021 e 2022, existe uma mobilização institucional para a retomada do orçamento participativo por videoconferência, primeiro reunindo O COP, depois os fóruns temáticos, finalizando com a retomada dos ciclos de debates nas 17 regiões. Os 92 participantes do COP representam as temáticas e as 17 regiões.

Em Porto Alegre, desde 2020, o processo de mobilização tem enfrentado dificuldades para uma maior participação da população. Apesar dos 
"negacionistas", grupos que ficaram conhecidos por apoiar políticas públicas que iam na contramão do combate à pandemia, a sociedade buscou se organizar para conter o avanço das novas variantes que surgiam a todo tempo, em diferentes localidades do país. Como consequência, e necessariamente, os constantes lockdowns dificultaram ainda mais a situação de extrema miséria vivenciada por um número cada vez maior de brasileiros, a cada dia. Nesse contexto, é cada vez menor a condição de participação da população no processo de decisão sobre as definições das prioridades orçamentárias do município. Mesmo assim, destaca-se que as determinações da CF de 1988, por meio de sua regulamentação, dos dispositivos do Estatuto da Cidade e da Lei de Responsabilidade Fiscal, mantêm a obrigatoriedade da realização de debates, audiências e consultas públicas para a aplicação dos recursos orçamentários por meio do PPA, da LDO e LOA. A despeito dessas determinações, as instâncias que convocavam essas participações praticamente se exauriram com as medidas adotadas em âmbito federal, estadual e municipal de combate à pandemia.

Não obstante, de variadas formas, alguns municípios buscam incentivar, pelos seus portais da administração pública, a participação da população na votação de algumas prioridades, que são julgadas necessárias a essa população. O município de Pinhais, que já teve como destaque de sua gestão o orçamento participativo em anos passados, agora utiliza os meios digitais para coletar as demandas e prioridades da população. Busca, por força da lei, a partir de seus gestores, garantir pelo menos a realização das audiências públicas. Nos anos de 2020 e 2021, foram realizadas as coletas de formulários contendo as demandas prioritárias da população de forma on-line, assim como as próprias audiências públicas, alcançando uma participação popular muito aquém do esperado. Isso representou uma preocupação diante de comparação com as participações da população em anos anteriores, quando não havia a Covid-19. Antes da pandemia, as consultas, além dos panfletos e site da prefeitura, eram realizadas reuniões, de forma presencial, em cada uma das quatro regiões do orçamento definidas pelo Poder Executivo local. 
O município de Curitiba, também como forma de seguir as determinações da lei, criou o programa Fala Curitiba, que, a partir de formulários disponíveis em cada uma das dez administrações regionais disponíveis no site da Prefeitura Municipal, coleta, desde o início de março até maio, as prioridades da população curitibana. A partir do mês de maio, começa o detalhamento das demandas apresentadas pelos moradores. Também em maio, são apontadas as temáticas que podem ser levadas para o debate do orçamento do ano seguinte. Da mesma forma que Pinhais, durante o período da pandemia, Curitiba realizou suas atividades do orçamento toda de forma on-line, desde as consultas por instrumentos digitais até as escolhas das demandas das audiências públicas. Não surpreendeu o fato de que o número de participantes que escolheram as prioridades, dentre os temas apresentados, também tenha caído.

É certo que a queda acentuada dos participantes, comparada com anos anteriores, tenha sido influenciada pela pandemia de Covid-19, que dificultou a realização das diversas plenárias nos diferentes espaços geográficos estabelecidos pelas secretarias regionais e seus bairros. Outros fatores, como a pouca divulgação e a própria dificuldade de acesso aos meios digitais por parte da população, também afetaram negativamente os resultados da consulta pública. Além disso, não há em Curitiba um processo de participação democrática que envolva a população diretamente na decisão orçamentária; as pessoas apenas indicam as prioridades e as decisões acabam sendo tomadas pela Câmara Legislativa e pelo Executivo municipal.

Ainda que fosse de interesse dos gestores o envolvimento da população no processo decisório sobre a implementação, administração e fiscalização dos recursos públicos, objetivando diminuir as desigualdades sociais estabelecidas em sua dimensão espacial, as condições impostas por um lockdown ou isolamento social dificultaram essa possibilidade. A inclusão dos grupos populacionais geograficamente mais vulneráveis nesse debate sobre a gestão pública e democrática, com justiça territorial, se tornou praticamente impossível na metodologia desenvolvida, em 2021, para esse processo decisório. O mais 
agravante é que boa parte dessa população não possui acesso aos recursos econômicos para a satisfação de suas necessidades básicas e de suas famílias, quem dirá recursos para acessar os meios digitais necessários para visitar os portais das prefeituras. Dessa forma, a decisão do orçamento público para o ano seguinte fica restrita às propostas encaminhadas pelos representantes do poder local (grupos políticos partidários, representantes das associações comerciais e industriais, parlamentares e Poder Executivo).

\section{CONSIDERAÇÕES FINAIS}

As análises realizadas nesta pesquisa sobre o orçamento participativo como um instrumento de transformação do espaço urbano deixam claro que, se houver vontade política e um envolvimento da população, a apropriação dos recursos obtidos a partir do excedente de produção, alcançados pelas grandes cidades, poderá ser realizada de forma justa. O desenvolvimento geográfico desigual, ocorrido nas cidades-polo, em relação às demais cidades que compõem a região metropolitana, tende a ser minimizado pelo orçamento participativo e um empenho maior dos gestores públicos interessados na realização de um

planejamento comum envolvendo os municípios, o estado e o governo federal, além de um órgão de gestão metropolitana e de representantes dos movimentos sociais organizados e da sociedade civil.

Os problemas decorrentes dos processos eleitorais municipais tornaram mais difícil apresentar propostas que possam tornar mais democrática a gestão pública. Nas últimas eleições em todo o país, o receio de ter sua campanha eleitoral atingida por alguns dos ferrenhos defensores das formas indiretas de participação, assim como daqueles que representam as tradicionais oligarquias partidárias brasileiras, fez com que algumas das bandeiras levantadas pelos partidos de esquerda e, principalmente, pelo PT fossem abandonadas para reverter as tendências de derrotas nos pleitos eleitorais que se seguiram. Dentre 
essas bandeiras, estava o orçamento participativo, que acabou sendo sacrificado por setores dos partidos de esquerda, que resolveram ceder aos interesses daqueles que estão sempre afoitos para retomar ou manter os seus privilégios.

Durante os anos de vigência nas cidades em que foi implementado, o orçamento participativo não agradou a todos, principalmente aqueles que se diziam representantes da vontade popular, por terem sido eleitos para a Câmara Legislativa ou ocuparem certos cargos dentro do Poder Executivo. Antes do orçamento participativo, esses cargos eram controlados pelos poucos atores que mantinham sob seu domínio as informações sobre o orçamento público e suas aplicações. Assim, uma proposta de participação direta da população na decisão e na fiscalização do orçamento público, como ocorreu nos primeiros 16 anos de implementação do orçamento participativo em Porto Alegre e em outras experiências sólidas, como em Chapecó (SC) e Maringá (PR), só poderá ser efetivada com muita vontade das organizações políticas partidárias e a efetiva participação da população.

Em Porto Alegre, já existe um interesse dos gestores públicos em mudar o Regimento Interno do Orçamento Participativo, o que significa restringir ainda mais a participação direta dos conselheiros do orçamento participativo e da população na decisão, gestão e execução do orçamento. Apesar de não negarem a importância desse instrumento de gestão, sob o argumento da Covid-19, é possível que os passos a ser dados sejam em direção à redução do número de representantes no COP e nas atividades do orçamento participativo. Apesar disso, a prefeitura e os representantes do COP e das plenárias temáticas persistem na realização do programa, disponibilizando um link no portal da Prefeitura Municipal para que a população possa apresentar as suas demandas.

A pandemia do coronavírus veio dificultar a participação popular em espaços que ainda são abertos pelas prefeituras que buscam seguir a CF (1988) e o Estatuto da Cidade (2001). Curitiba, uma cidade sem tradição no âmbito da democracia direta, pois durante a maior parte de sua história conviveu com prefeitos e legisladores que não renunciavam à forma tradicional de governar, 
aos poucos tem realizado esforços em abrir espaços para a opinião da população, o que não é efetivamente um processo de democracia direta, como exige o orçamento participativo.

Desde 2016, de acordo com Silva (2017), a Prefeitura de São José dos Pinhais, por meio de seus gestores públicos, vem utilizando o termo "orçamento participativo" para denominar as audiências públicas da LOA que vêm ocorrendo no município. De acordo com o órgão, durante o ano de 2021, devido à Covid19 , as consultas públicas ocorreram pelo formato remoto, buscando preservar a integridade física da população. Dessa forma, apesar de as audiências públicas presenciais não ocorrerem nesse formato, o espaço de participação da população no orçamento participativo foi preservado. Por mais que o nome tenha relação com o programa criado em Porto Alegre, a iniciativa da Prefeitura de São José dos Pinhais não possui a mesma dinâmica e organização do orçamento participativo da capital gaúcha.

Em Pinhais, os esforços ocorrem no sentido de demonstrar continuidade ao antigo processo do orçamento participativo. A Covid-19 trouxe dificuldades ainda maiores aos gestores públicos de tentar demonstrar que a população é ouvida nas audiências públicas do orçamento, as quais ocorrem como uma formalização do que exige a LDO; por mais que se expresse um esforço para que a população participe, elas jamais se aproximaram de um processo de democracia direta da população nas escolhas das prioridades, na elaboração da LOA e na sua execução, fiscalização e prestação de contas.

Para transformar as audiências públicas em orçamentos participativos, é necessário que os objetivos mudem por parte daqueles que estão à frente dos Poderes Executivos e Legislativos municipais, principalmente na partilha do poder com os diferentes setores da sociedade, fazendo com que o produto resultante da produção de riqueza da cidade alcance escalas mais abrangentes, envolvendo principalmente os moradores dos bairros mais pobres e segregados espacial e geograficamente. É preciso, por meio de instrumentos de democracia participativa como o orçamento participativo, promover a justiça espacial. 


\section{REFERÊNCIAS}

AVRITZER, Leonardo. Sociedade civil e Estado no Brasil: da autônoma à interdependência política. Vol. 18, n² 2, p. 383 -398. Campinas: Opinião Pública, 2012.

BRANDÃO, Elias Canuto (org.) Orçamento Participativo: avanços, limites e desafios. Maringá: Massoni, 2003.

CARLOS, A. F. A. A (re) produção do espaço urbano. São Paulo: Edusp, 2007.

FEDOZZI, Luciano. 0 eu e os outros. A construção da consciência social no Orçamento Participativo de Porto Alegre, 2002. 339. Tese (Doutorado) - Universidade Federal do Rio Grande do Sul, Porto Alegre

FEDOZZI, Luciano. O eu e os outros: participação e transformação da consciência moral e cidadania. Porto Alegre: Tomo Editorial, 2008.

GARBOSSA, Renata Adriana. SILVA, Rodolfo dos Santos. O processo de produção do espaço urbano: impactos de uma nova urbanização. Curitiba: intersaberes, 2016.

GONÇALVES, Hermes Laranja. Uma visão crítica do Orçamento Participativo. Vitória-ES: Lumen/Juris, 2005.

LEFEBVRE, H. A revolução urbana. São Paulo: Editora Centauro, 2001.

HARVEY, David. A produção capitalista do espaço. São Paulo: Annablume, 2005.

HARVEY, David. A liberdade da cidade. Revista Espaço e Tempo São Paulo: GEOUSP, 2009 p.09-17.

LÜCHMANN, Ligia Helena Hahn. 25 anos de Orçamento Participativo: algumas reflexões analíticas. Florianópolis: Política e Sociedade- Vol-13, n² 28 - Set./dez, 2014.

MARICATO, Ermínia. Para entender a crise urbana. São Paulo: Expressão Popular, 2015.

PIRES, Valdemir. Orçamento participativo: o que é, para que serve, como se faz. Barueri-SP: Manole, 2001.

PMSJP - Prefeitura Municipal de São José dos Pinhais.

SANTOS, Milton. O espaço dividido: os dois circuitos da economia urbana dos países subdesenvolvidos. São Paulo: Editora da Universidade de São Paulo, 2008.

PONT, Raul. A democracia, participação, cidadania: uma visão de esquerda. Porto Alegre: Palmarinca, 2000.

PORTO DE OLIVEIRA, Osmany. Mecanismos da difusão global do Orçamento Participativo: indução internacional, construção social e circulação de indivíduos. Campinas: Opinão Pública, 2016.

PMPOA, Prefeitura Municipal de Porto Alegre. Realizada primeira reunião com a Comissão de Despesa do Orçamento Participativo. Disponível in:https://prefeitura.poa.br/smgov/noticias/realizada-primeira-reuniao-com-comissao-de-

receita-e-despesa-do-orcamento

SÃO JOSÉ DOS PINHAIS, Prefeitura Municipal. Orçamento participativo de 2021 promove consultas virtuais. Disponível in: http://www.sjp.pr.gov.br/orcamento-participativo-de-2021promove-consultas-publicas-virtuais/

PMP- Prefeitura Municipal de Pinhais.

SILVA, Rodolfo dos Santos. Orçamento Participativo como mecanismo de transformação do espaço urbano. Tese de Doutorado. Curitiba: Universidade Federal do Paraná, 2017.

SINTOMER, Y; HERZBERG, C.; ROCKE, A. Modelos transnacionais de participação cidadã: o caso do Orçamento Participativo. Sociologia, v. 14, n.30, p. $70-116,2012$.

WAMPLER, Brian. A difusão do Orçamento Participativo brasileiro. "Boas práticas" devem ser promovidas? Revista Opinião Pública - v. $14-n^{\circ} .1$-p.65-95. Campinas: Opinião Pública, 2008. 


\section{CAPÍTULO 4 - DINÂMICAS SOCIOESPACIAIS DO EMPREGO E DO DESEMPREGO NO BRASIL NO CONTEXTO DA PANDEMIA DE COVID-19}

\section{ALCELI RIBEIRO ALVES ${ }^{13}$}

\section{INTRODUÇÃO}

Em novembro de 2019, poucas pessoas poderiam imaginar que a divulgação do caso de um cidadão chinês contaminado pelo então chamado novo coronavírus poderia resultar em transformações tão rápidas e significativas no mundo, sob diversas perspectivas e dimensões possíveis de análise. A contaminação supostamente teria ocorrido em novembro daquele ano e, conforme alegou-se à época, teria como epicentro um mercado de Wuhan, na China.

Eis que a comunidade científica identificou o vírus causador da doença, o SARS-CoV-2, e, em 11 de fevereiro de 2020, a Organização Mundial da Saúde (OMS) atribuiu nome para a doença causada por esse vírus, Covid-19, do inglês Corona Virus Disease. Com a rápida difusão do vírus no espaço geográfico, a OMS monitorava a concentração espacial do vírus na Ásia, bem como sua possível difusão para os demais continentes, ou seja, buscando compreender a geografia da Covid-19 e suas implicações para os sistemas de saúde. Um mês após ser cunhada e sua denominação tornar-se pública, a Covid-19 mudou de patamar. Em 11 de março de 2020, com a declaração feita pelo diretor geral da organização, Dr. Tedros Adhanom, a OMS anunciou a elevação do estado da contaminação para pandemia. Dr. Tedros explicou que "a mudança de

\footnotetext{
13 Doutor em Geografia pela UFPR. Mestre em Geografia pela Queen Mary University. Professor e pesquisador no Centro Universitário Internacional Uninter.
} 
classificação não se deve à gravidade da doença, mas sim à sua rápida disseminação geográfica" (EBC, 2020).

A partir da divulgação do aumento gradual no número de casos na China e da difusão para as regiões vizinhas e, posteriormente, para a Europa e Estados Unidos, se acendeu o alerta para a humanidade, indicando que as sociedades ao redor do mundo deveriam redobrar seus cuidados para evitar o aumento no número de contaminados e de mortes, ou seja, uma luta em prol da saúde e da sobrevivência das pessoas. Além dos cuidados relativos à higiene pessoal, houve a necessidade de os países imporem restrições à mobilidade das pessoas no espaço geográfico, o fechamento de fronteiras, bem como medidas de distanciamento social e confinamento (lockdown) em determinadas regiões. Para além dessas mudanças, a saúde pública nos países foi severamente atingida, as relações de trabalho e emprego também mudaram e as economias foram fortemente afetadas.

No Brasil, o primeiro caso diagnosticado da doença foi confirmado no dia 26 de fevereiro de 2020, de um cidadão que tinha 61 anos e estivera na Itália dias antes de sua chegada ao Brasil. A partir de então, o número de casos oscilou bastante, tanto para o número de contaminados quanto para o número de óbitos causados por Covid-19.

No que concerne à análise que pretendemos realizar aqui, estabelecer um recorte temporal para definir por quanto tempo os impactos da pandemia da Covid-19 afetaram ou afetarão a economia brasileira e, em particular, as admissões e desligamentos de trabalhadores nos diferentes setores da atividade econômica não é uma tarefa trivial. A temporalidade dos efeitos, sejam eles positivos ou negativos, está diretamente relacionada ao ritmo em que se corre em busca do desenvolvimento, produção e distribuição de vacinas e, obviamente, da imunização das populações no mundo.

Para compreender as dinâmicas socioespaciais do emprego e do desemprego no Brasil no contexto da pandemia de Covid-19, há de se considerar, além das transformações causadas diretamente pela pandemia, todas as condições anteriores, ou seja, compreender a história de construção e 
valorização de estruturas preexistentes nos territórios, a capacidade das empresas para inovar e incorporar tecnologias, a capacidade das empresas e de seus colaboradores para superar os desafios da atualidade sem que a solução mais imediata para os problemas seja a redução no número de postos de trabalho e a consequente demissão dos trabalhadores. Desse modo, trata-se de uma questão de interesse público e nacional, na medida em que envolve o papel do Estado na adoção de medidas e na implantação de políticas públicas para satisfazer as necessidades de seus cidadãos e garantir os direitos sociais, mas também uma questão que envolve diretamente a iniciativa privada e, em particular, as empresas. Estas, assim como o Estado, possuem uma função social relevante, pois têm a capacidade de gerar oportunidades de trabalho e emprego.

Nosso recorte temporal, portanto, é subjetivo, apesar de ter critérios bem definidos. O capítulo como um todo considera marco inicial da pandemia a manifestação e registro oficial do primeiro caso ocorrido em 2019, na China. Como marco final, temos o cenário atual em que o país se encontra e que podemos analisar antes da publicação desta obra. Obviamente, as transformações que a economia, o espaço geográfico brasileiro e a sociedade de modo geral ainda sofrerão deverão servir como dados (ou insumos) para que futuras análises possam lançar luz sobre os temas e questões tratados até este momento. Em outras palavras, estamos cientes de que nossa análise possui um foco bem limitado, temporal, econômica, socialmente etc., de modo que reconhecemos que inúmeras lacunas serão deixadas.

No que concerne aos procedimentos metodológicos, é possível adotar como marco inicial da pandemia o registro oficial do primeiro caso ocorrido em 2019, em Wuhan, na China, ou, ainda, a elevação da doença ao patamar de Pandemia, conforme declaração realizada em março de 2020 pela OMS. Agora, para efeitos de análise do emprego e do desemprego no Brasil durante a pandemia, vamos estabelecer um recorte mais limitado ainda, qual seja, o ano de 2020, haja vista que as transformações no mercado de trabalho brasileiro ocorreram de maneira significativa particularmente em 2020, e não em 2019. 
Até o momento da redação final deste capítulo, foi possível coletar e analisar os dados disponíveis no Cadastro Geral de Empregados e Desempregados (Caged) referentes às admissões e desligamentos entre janeiro e dezembro de 2020.

Façamos uma breve consideração sobre o Caged. De acordo com a Secretaria Especial de Previdência e Trabalho, órgão do Ministério da Economia (SEPRT-ME, 2020, p.1), ele serve como

Instrumento de acompanhamento e de fiscalização do processo de admissão e de dispensa de trabalhadores regidos pela Consolidação das Leis do Trabalho (CLT), com o objetivo de assistir os trabalhadores desempregados e de apoiar medidas contra o desemprego.

Serve também como importante banco de dados, bastante conhecido por pesquisadores de diversas áreas dedicados à análise das variações no emprego e desemprego e suas implicações nos diferentes lugares.

Nossa análise considera a variação das admissões e desligamentos em diversas escalas de análise e setores da atividade econômica, sem nos dedicarmos, porém, à particularidade dos municípios. Assim, a primeira seção deste capítulo é dedicada à análise da competência concorrente dos entes federativos no enfrentamento à pandemia de Covid-19. Em seguida, analisamos a flexibilização da legislação trabalhista no Brasil, como ação importante nesse contexto de enfrentamento à pandemia e, sobretudo, como medida adotada pelo governo federal com o objetivo de evitar demissões e garantir postos de trabalho.

Na terceira seção, o objetivo consiste em analisar as transformações no mercado de trabalho brasileiro, considerando as variações no emprego e no desemprego a partir da escala nacional. Posteriormente, ainda no âmbito da escala nacional, analisamos os impactos da pandemia nos diferentes setores da atividade econômica. Essa análise é seguida de uma breve consideração sobre o saldo do emprego, a criação de vagas ou, ainda, a perda de postos de trabalho nas cinco macrorregiões brasileiras. Em outras palavras, nossa tarefa aqui consiste em analisar, numa escala bastante abrangente, a geografia do emprego 
e do desemprego no Brasil durante o ano de 2020 no contexto da pandemia de Covid-19.

Por último, mas não menos importante, realizamos um estudo com uma abordagem setorial, privilegiando as transformações mais recentes na indústria automobilística mundial e, sobretudo, suas implicações para as dinâmicas socioespaciais do emprego e do desemprego nesse setor.

\section{A COMPETÊNCIA CONCORRENTE DOS ENTES FEDERATIVOS NO ENFRENTAMENTO À PANDEMIA DE COVID-19}

Num cenário alarmante e de crescimento no número de pessoas diagnosticadas com Covid-19 no início de 2020 e mortes e de redução no número de admissões, associada ao número de desligamentos, o governo federal decidiu adotar diversas ações para minimizar os impactos gerados pelo coronavírus. Dentre essas ações, e como consequência da disseminação do vírus em várias regiões do planeta, foi decretado o estado de calamidade pública. No documento enviado ao Congresso Nacional, o presidente Jair Bolsonaro justificou que os impactos ocasionados pela pandemia ultrapassavam a questão da saúde pública e causavam forte desaceleração nas atividades econômicas. Assim, em 18 de março de 2020, o Senado Federal acolheu o pedido do presidente para reconhecer o estado de calamidade pública.

Com o Decreto Legislativo no 6/2020, o governo federal ficaria dispensado, naquele momento, de cumprir a meta fiscal determinada para o ano entre despesas e receitas, haja vista a necessidade de gastar mais em saúde do que o previsto e aprovado na Lei Orçamentária Anual (LOA) para o ano de 2020 (BRASIL, 2020). A vigência do decreto que reconheceu o estado de calamidade pública terminou em 31 de dezembro de 2020, mas os desafios para a saúde pública e para a economia permaneceram. Por isso, a Portaria MS no 188/2020, que declarou emergência em saúde pública de importância nacional, surtiu efeito até 2021. 
O que é necessário destacar nesse contexto é a competência concorrente dos entes federativos no enfrentamento à pandemia de Covid-19, ou seja, não apenas a União, mas também os estados, o Distrito Federal e os municípios têm o dever de adotar ações que minimizem os impactos causados pela pandemia na saúde das pessoas e, consequentemente, na economia de cada ente da federação. A norma está prevista no art. 23 da Constituição da República Federativa do Brasil.

Art. 23. É competência comum da União, dos Estados, do Distrito Federal e dos Municípios:

II - cuidar da saúde e assistência pública, da proteção e garantia das pessoas portadoras de deficiência;

A relevância de trazer essa discussão em torno da competência dos entes no tocante ao enfrentamento da pandemia de Covid-19 é fundamental, porque, em meados de 2020, por diversas vezes, o presidente da República, Jair Bolsonaro, insistiu em afirmar que caberia aos estados e municípios a tarefa de responder à ameaça da Covid-19. A respeito, a matéria de Mota (2020), publicada em 6 de julho de 2020 pela BBC, destaca que "os especialistas ressaltaram que o presidente teria distorcido o teor de uma decisão proferida pelo Supremo Tribunal Federal (STF)". Em 22 de junho de 2020, o ministro do Supremo Luiz Fux tratou novamente do assunto e afirmou que a ADPF $672^{14}$ reconhecia a competência concorrente de estados e municípios e não eximia o governo federal de suas responsabilidades no enfrentamento à pandemia. Logo, vimos que há previsão legal e expressa na Constituição que reitera a responsabilidade do Executivo federal no tocante ao enfrentamento da pandemia de Covid-19 e que tal norma foi novamente apreciada e referendada pelo plenário do Supremo Tribunal Federal.

\footnotetext{
14 Trata-se de Arguição de Descumprimento de Preceito Fundamental proposta pelo Conselho Federal da Ordem dos Advogados do Brasil em face de atos omissivos e comissivos do Poder Executivo federal, praticados no contexto da crise de saúde pública decorrente da pandemia da Covid-19.
} 


\section{A FLEXIBILIZAÇÃO DA LEGISLAÇÃO TRABALHISTA NO BRASIL NO CONTEXTO DA PANDEMIA DE COVID-19}

Outras medidas foram adotadas para flexibilizar a legislação trabalhista com o argumento do governo federal de que o objetivo seria garantir os postos de trabalho e evitar demissões. Para isso, o presidente Jair Bolsonaro publicou as Medidas Provisórias (MPs) no 927/2020 e no 936/2020. A primeira trata de medidas trabalhistas para enfrentamento da emergência de saúde pública decorrente do coronavírus, enquanto a segunda instituiu o Programa Emergencial de Manutenção do Emprego e da Renda e dispôs sobre medidas trabalhistas complementares para enfrentamento do estado de calamidade pública reconhecido pelo Decreto Legislativo no 6/2020 e da emergência de saúde pública de importância internacional decorrente do coronavírus (Covid19), de que trata a Lei no 13.979/2020 (CONGRESSO NACIONAL, 2020).

A MP no 927/2020, publicada em 22 de março desse ano, não foi votada nas duas casas do Congresso Nacional e perdeu eficácia no dia 20 de julho, embora tenha gerado efeitos durante o prazo de vigência. Ela buscava flexibilizar regras trabalhistas que permitiriam aos empregadores a negociação de forma direta com os funcionários, sem a participação dos sindicatos, em acordos sobre o teletrabalho, antecipação de férias e feriados, banco de horas, adiamento do recolhimento do Fundo de Garantia do Tempo de Serviço (FGTS) por três meses etc. Já a MP no 936/2020 foi apreciada pelas duas Casas e transformou-se em norma jurídica com veto parcial, tendo entrado em vigor em $1^{\circ}$ de abril de 2020 e, após sanção do presidente em 6 de julho de 2020, se tornado norma pela Lei no $14.020 / 2020$.

Dentre as medidas previstas no Programa Emergencial de Manutenção do Emprego e da Renda, constavam: o pagamento do benefício emergencial de preservação do emprego e da renda; a redução proporcional de jornada de trabalho e de salário; e a suspensão temporária do contrato de trabalho. A partir do primeiro dia útil de 2021 (4 de janeiro), voltaram a valer os contratos de trabalho que existiam antes da pandemia. 
Veremos que tais medidas auxiliaram as empresas nos momentos mais críticos da pandemia no primeiro semestre de 2020 e contribuíram, em certa medida, para evitar demissões em massa. Isso fica demonstrado pelo número de admissões e redução no número de desligamentos, sobretudo após julho de 2020, conforme discutido na seção seguinte. Essa tendência levou o ministro da Economia, Paulo Guedes, a afirmar no dia 4 de novembro de 2020, em evento realizado no Palácio do Planalto, que a pandemia da COVID-19 estava cedendo, e ao mesmo tempo, a economia estava voltando (SABINO, 2020) Contudo, apesar de parecer um cenário promissor para o segundo semestre de 2020, indicando a recuperação da economia e a perda da força dos impactos negativos da pandemia no Brasil, os números no país no final de 2020 e início de 2021 nos mostraram que ela continuou causando muitas mortes e o número de pessoas diagnosticadas permaneceu em patamares elevados. Em março de 2021, com o baixo índice de humanização da população e fortes críticas ao governo Bolsonaro, alegava-se que o Brasil havia se tornado o novo epicentro da doença no mundo.

\section{EMPREGO E DESEMPREGO NO BRASIL NO CONTEXTO DA PANDEMIA DE COVID-19}

\section{A variação do emprego no brasil durante a pandemia de covid-19}

A partir dessas considerações, iniciemos pela análise da evolução das admissões ocorridas entre janeiro e dezembro de 2020, período em que os impactos da pandemia resultaram em fortes quedas no número de admissões, sobretudo no primeiro semestre. Aqui, admissões representam emprego com carteira assinada e contratos regidos pela CLT e desligamentos significam demissões.

Desde o surgimento do primeiro caso de contaminação pelo coronavírus, supostamente em novembro de 2019, na China, o Brasil parecia não se sentir 
abalado com os fatos ocorridos no Leste Asiático e com as notícias cada vez mais alarmantes sobre a difusão da doença e o rápido crescimento no número de mortes naquela região. Obviamente, a OMS, o Ministério da Saúde do Brasil e diversos outros ministérios (como o da Economia) e países de todo o mundo acompanhavam os desdobramentos e a evolução da doença na escala macrorregional da Ásia e seu potencial para atingir outros países na região ou mesmo em regiões mais distantes, considerando as dinâmicas inerentes ao processo de globalização. Contudo, com a declaração da OMS, em fevereiro de 2020, de que o vírus se alastrara para todos os continentes, tornando-se uma pandemia, não demorou muito para que as reações dos governos, empresas e empregadores no Brasil se tornassem notórias. O Gráfico 4.1 nos mostra que houve uma ligeira redução no número de admissões entre fevereiro e março de 2020, primeiro indicativo de que a pandemia começara a gerar seus impactos no mercado de trabalho no Brasil. Mas foi justamente entre março e abril que se observou a mais expressiva queda no número de admissões no mercado de trabalho brasileiro no ano de 2020. Se, em fevereiro de 2020, o número de admissões foi de 1.605 .389 , em março esse número caiu para 1.449 .957 e em abril chegamos ao menor índice, 650.166 admissões, o que representou uma redução de 59,5\% quando comparado com as admissões reportadas no mês de fevereiro do mesmo ano. 
Gráfico 4.1 - Evolução das admissões no mercado de trabalho brasileiro entre janeiro e dezembro de 2020

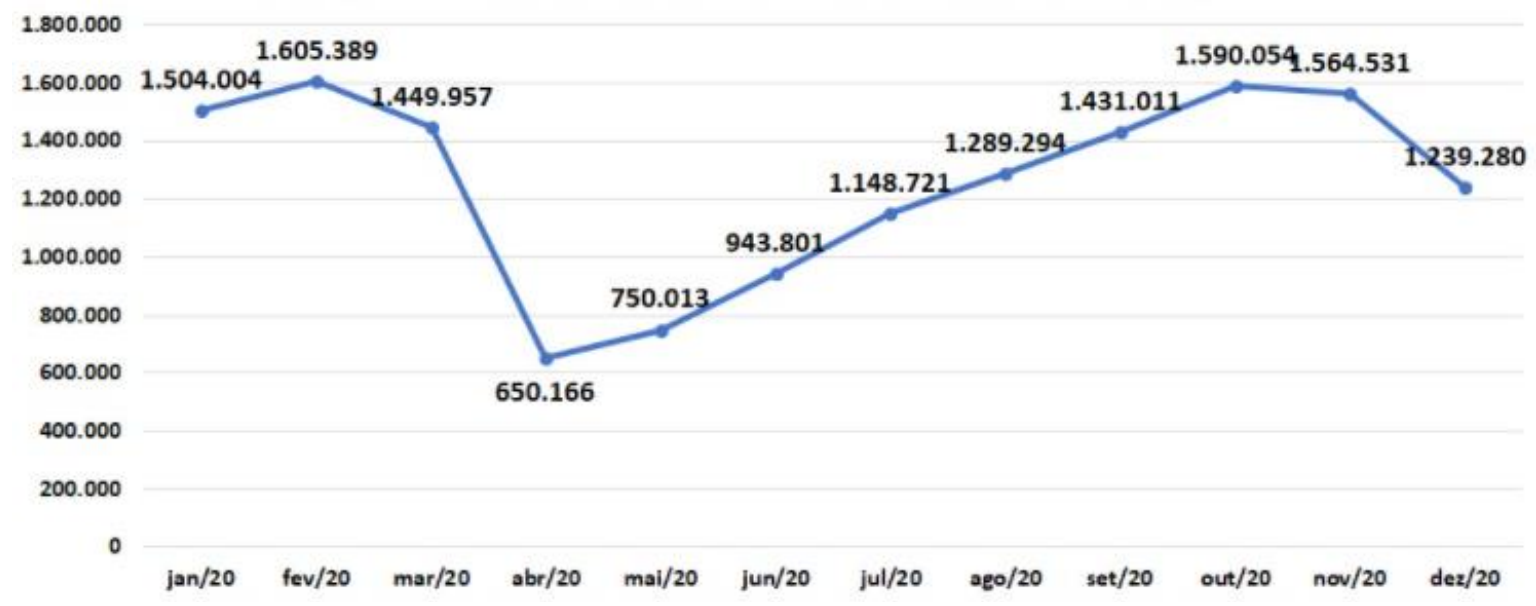

Fonte: CAGED/PDET, 2021.

Apesar do baixíssimo desempenho nas admissões em abril, a partir daquele mês o número de admissões foi gradativamente aumentando, até que em dezembro de 2020 o mercado de trabalho chegou a patamares pouco inferiores àqueles atingidos em janeiro e março do mesmo ano. Isso demonstra uma clara recuperação do emprego no Brasil a partir do olhar para as admissões - ressalva para os meses de novembro e dezembro de 2020, que indicaram queda no número de admissões e, quiçá, uma nova tendência que deveria ser observada e analisada considerando os dados do início/meados de 2021.

\section{A variação do desemprego no brasil durante a pandemia de covid-19}

Para além das estatísticas e das mudanças no mercado de trabalho, a pandemia gerou um sentimento de angústia nas pessoas, com o receio de demissões e enormes desafios para a administração pública, em diversas escalas de governo. De fato, as demissões ocorreram e foram bastante significativas. Contudo, há uma variação muito grande de setor para setor, de modo que alguns setores contrataram mais e outros demitiram mais. 
Quando se analisa o número de desligamentos na escala nacional, percebe-se que, no primeiro quadrimestre de 2020, houve uma forte tendência de aumento no número de desligamentos. $O$ ápice que revela o pior momento de transformações no mercado de trabalho brasileiro em 2020, na perspectiva das demissões, foi o mês de março, com 1.722.765 desligamentos (Gráfico 4.2). Chama atenção, porém, a tendência crescente no número de desligamentos a partir de junho e, sobretudo, o número de desligamentos em dezembro de 2020.

Gráfico 4.2 - Evolução dos desligamentos no mercado de trabalho brasileiro entre janeiro e dezembro de 2020

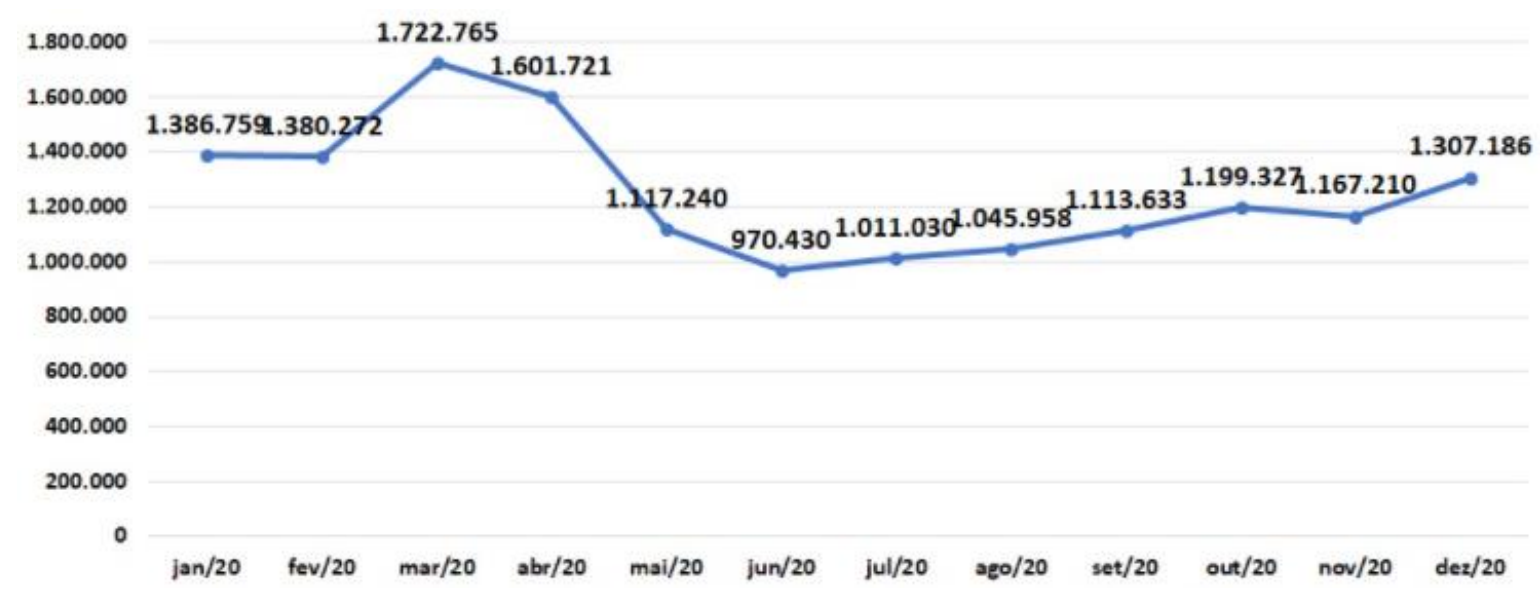

Fonte: CAGED/PDET, 2021.

Os desligamentos diminuíram significativamente em junho de 2020, quando comparados ao mês de março do mesmo ano, mas, conforme vimos, o número de demissões voltou a aumentar gradativamente até o mês de dezembro. Essa tendência negativa pode ser relacionada a diversos fatores, desde a consideração do posicionamento do governo federal em relação à pandemia até o ânimo dos empregadores sobre o futuro da economia e de seus próprios negócios.

Sabemos que o governo federal e, sobretudo, a Presidência da República do Brasil posicionaram-se de maneira muito radical e divergente em relação à maioria dos países do mundo quanto à Covid-19. Para além da política econômica, dos frágeis elos estabelecidos no âmbito das relações exteriores e 
do ambiente político no país, a descrença na ciência e os discursos que minimizavam a gravidade da doença causada pelo vírus desgastaram não apenas a imagem do presidente Jair Bolsonaro, mas também o interesse de alguns investidores para continuar atuando no país. Não por acaso, muitas pequenas empresas tiveram de fechar suas portas e até mesmo empresas multinacionais reconsideraram seu posicionamento estratégico com relação ao Brasil, até mesmo em escala global. O encerramento das operações de produção e fechamento das fábricas da Ford no Brasil são exemplos importantes nesse contexto, mas é claro que outras variáveis (como carga tributária do país, corte nos incentivos fiscais etc.) também estavam em jogo nessa questão.

É importante relacionar admissões e desligamentos para compreender que os empregadores seguiram uma tendência lógica durante a pandemia em 2020, qual seja, contratar menos durante os meses de março e abril, ao mesmo tempo que demitiram mais durante o referido período. Isso se reflete no saldo entre admissões e desligamentos durante o período considerado (Gráfico 4.3).

Gráfico 4.3 - Evolução do saldo entre janeiro e dezembro de 2020

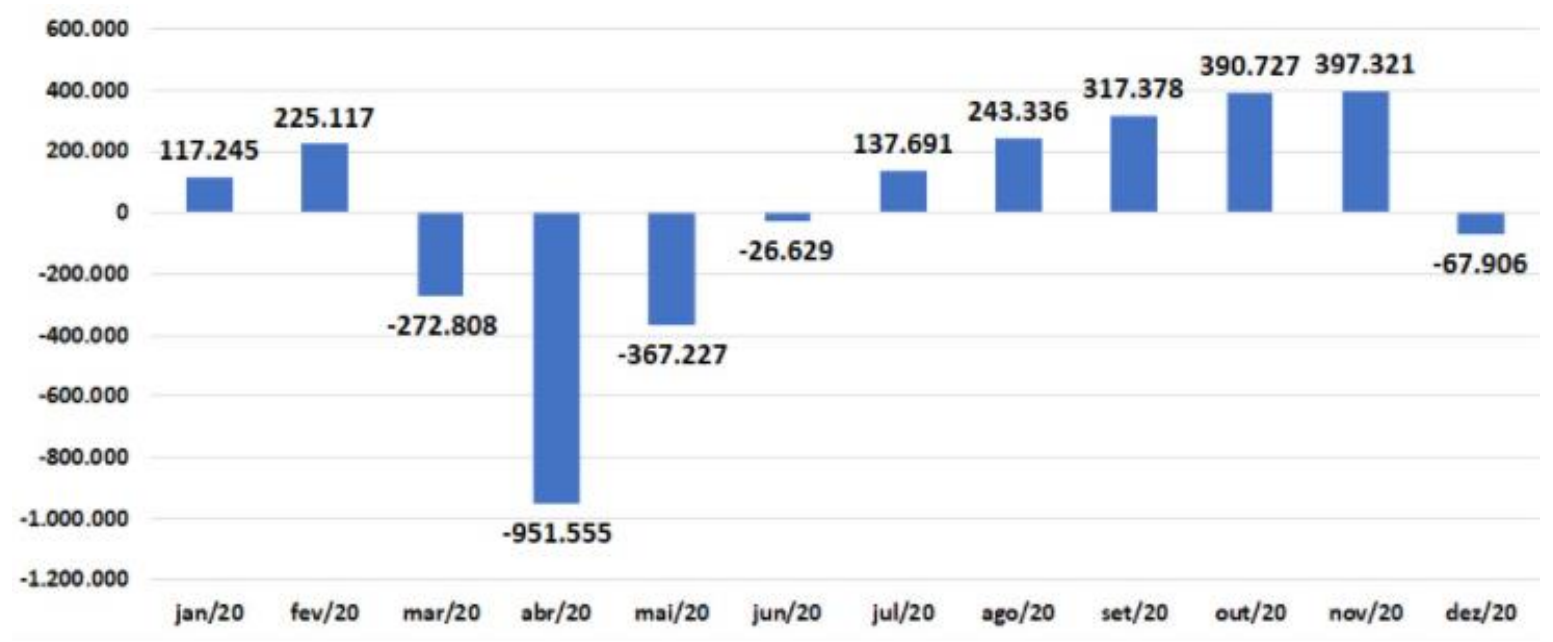

Fonte: CAGED/PDET, 2021.

O Gráfico 4.3 nos mostra que o saldo envolvendo admissões e desligamentos foi negativo entre os meses de março e junho de 2020 e que o número de admissões superou o de desligamentos entre julho e novembro de 
2020. Esse saldo positivo, a partir de julho de 2020, indica a criação de postos de trabalho ou geração de emprego, resultado da diferença entre admissões e desligamentos. Em outras palavras, os indicadores nos revelam que o mercado de trabalho sofreu transformações importantes durante a pandemia em 2020, mas a economia parece estar se recuperando e os empregadores, contratando mais e demitindo menos - ressalva, obviamente, para o mês de dezembro de 2020, que pode sugerir o surgimento de uma nova tendência, provocada, sobretudo, por novos picos da doença no país e temores quanto à celeridade no processo de vacinação da população brasileira em 2021.

Como se pode imaginar, uma nova e forte tendência de aumento no número de casos e mortes provocados por Covid-19, além da demora no processo de vacinação, ocasionará novas restrições para a circulação de pessoas, o fechamento ou controle de horário de funcionamento de estabelecimentos considerados não essenciais etc. Se essa tendência se firmar, novas incertezas influenciarão as decisões do empresariado e, consequentemente, haverá maior propensão para desligamentos e redução no número de contratações.

\section{OS IMPACTOS DA PANDEMIA NOS DIFERENTES SETORES DA ATIVIDADE ECONÔMICA}

Ao analisar o saldo envolvendo admissões e desligamentos de trabalhadores durante a pandemia no ano de 2020, percebemos que os meses mais conturbados se situaram entre março e junho, haja vista que o número de desligamentos superou o de admissões. Diante dessa constatação, vamos estabelecer esse recorte temporal mais crítico para a economia nacional e para o mercado de trabalho, em particular, e passemos a analisar quais setores sofreram as maiores perdas e quais conseguiram crescer, considerando as variações entre admissões e desligamentos durante esse período.

O setor que mais emprega nos país é o setor de serviços, que em março de 2020 contava com um estoque superior a 18 milhões de empregados (Tabela 
4.1). Numericamente, esse também foi o setor que mais sofreu com a pandemia em março, com 792.738 demissões. Por outro lado, quando consideramos a variação relativa, observamos que foram os setores de comércio e construção que sofreram as maiores quedas, com redução de 0,89\% e 0,81\%, respectivamente. Todos os setores apresentaram desempenho negativo durante o mês de março, indicando a queda do emprego formal no país e o aumento do desemprego.

Tabela 4.1 - Admissões e desligamentos em março de 2020 no Brasil, por grandes grupamentos de atividade econômica

\begin{tabular}{|c|c|c|c|c|c|}
\hline Setor & $\begin{array}{l}\text { Admitid } \\
\text { os }\end{array}$ & $\begin{array}{c}\text { Desliga } \\
\text { dos }\end{array}$ & Saldo & Estoque & $\begin{array}{c}\text { Vr. relativa } \\
(\%)\end{array}$ \\
\hline Agropecuária & 75.996 & 83.898 & -7.902 & $\begin{array}{c}1.499 .95 \\
2\end{array}$ & $-0,52$ \\
\hline Comércio & 334.680 & 416.890 & -82.210 & $\begin{array}{c}9.196 .9 \\
51\end{array}$ & $-0,89$ \\
\hline Construção & 134.796 & 152.920 & -18.124 & $\begin{array}{c}2.209 .0 \\
17\end{array}$ & $-0,81$ \\
\hline Indústria & 236.898 & 276.159 & -39.261 & $\begin{array}{c}7.570 .44 \\
9\end{array}$ & $-0,52$ \\
\hline Serviços & 667.587 & 792.738 & $\begin{array}{c}- \\
125.151\end{array}$ & $\begin{array}{c}18.403 \\
095\end{array}$ & $-0,68$ \\
\hline Não identificado & 0 & 160 & -160 & - & - \\
\hline Total & $\begin{array}{c}1.449 .95 \\
7\end{array}$ & $\begin{array}{c}1.722 .76 \\
5\end{array}$ & -272.808 & $\begin{array}{c}38.879 .1 \\
77\end{array}$ & $-0,70$ \\
\hline
\end{tabular}

Fonte: CAGED. Dados Setoriais, 2021.

Nota: - sem dados.

Lfedo

No mês de abril de 2020, o setor agropecuário esboçou uma pequena reação, minimizando as perdas de março. Ele continuou demitindo, mas em proporções menores - se, em março, houve 83.898 desligamentos no setor, em abril esse número caiu para 63.645. Já os demais setores sofreram forte queda, sobretudo o setor de construção (Tabela 4.2). 
Tabela 4.2 - Admissões e desligamentos em abril de 2020 no Brasil, por grandes grupamentos de atividade econômica

\begin{tabular}{lccccc}
\hline Setor & $\begin{array}{c}\text { Admitid } \\
\text { os }\end{array}$ & $\begin{array}{c}\text { Desliga } \\
\text { dos }\end{array}$ & Saldo & Estoque & $\begin{array}{c}\text { Vr. relativa } \\
\mathbf{( \% )}\end{array}$ \\
\hline Agropecuária & $\mathbf{5 7 . 9 2 8}$ & $\mathbf{6 3 . 6 4 5}$ & $\mathbf{- 5 . 7 1 7}$ & $\mathbf{1 . 4 9 4 . 2}$ & $\mathbf{- 0 , 3 8}$ \\
Comércio & 122.684 & 378.167 & -255.483 & $\begin{array}{c}8.941 .46 \\
8\end{array}$ & $-2,78$ \\
Construção & 63.775 & 137.426 & -73.651 & $\begin{array}{c}2.135 .36 \\
6\end{array}$ & $-3,33$ \\
Indústria & 98.781 & 310.997 & -212.216 & 7.358 .23 & $-2,80$ \\
Serviços & $\mathbf{3 0 6 . 9 9 8}$ & $\mathbf{7 1 1 . 4 5 2}$ & - & $\mathbf{1 7 . 9 9 8 .}$ & $\mathbf{- 2 , 2 0}$ \\
Não identificado & 0 & 34 & --34 & - & - \\
Total & 650.166 & 1.601 .72 & -951.555 & 37.927 .6 & $-2,45$ \\
& & 1 & & 22 & \\
\hline
\end{tabular}

Fonte: CAGED. Dados Setoriais, 2021.

Nota: - sem dados.

Para ter uma ideia, somente no setor de serviços, 711.452 trabalhadores foram demitidos; associada à redução nas contratações, a diminuição de empregos formais no setor chegou a quase meio milhão de postos em abril de 2020.

O setor agropecuário confirmou sua recuperação em maio e junho de 2020, apresentando mais admissões do que desligamentos nesses meses (Tabelas 4.3 e 4.4). O que explica, ao menos parcialmente, a geração de empregos e a melhora no desempenho desse setor é a forte demanda puxada pelos alimentos, que pode ser constatada tanto pelo aumento da produção e das exportações realizadas por esse setor, como no caso da soja, quanto pela dinâmica de emprego, conforme nos dedicamos a analisar neste trabalho. A propósito, a demanda por alimentos aumentou consideravelmente na escala global, haja vista que muitos países passaram por problemas semelhantes aos do Brasil durante a pandemia, com muitas pessoas em casa, confinamento em diversas regiões, restrições na circulação de pessoas etc. 
Tabela 4.3 - Admissões e desligamentos em maio de 2020 no Brasil, por grandes grupamentos de atividade econômica

\begin{tabular}{lccccc}
\hline Setor & $\begin{array}{c}\text { Admitid } \\
\text { os }\end{array}$ & $\begin{array}{c}\text { Desliga } \\
\text { dos }\end{array}$ & Saldo & Estoque & $\begin{array}{c}\text { Vr. relativa } \\
\text { (\%) }\end{array}$ \\
\hline Agropecuária & $\mathbf{7 4 . 1 7 6}$ & $\mathbf{5 8 . 3 4 6}$ & $\mathbf{1 5 . 8 3 0}$ & $\mathbf{1 . 5 1 0 . 0}$ & $\mathbf{1 . 0 6}$ \\
Comércio & 150.316 & 247.622 & -97.306 & $\begin{array}{c}\mathbf{6 5} \\
\text { (5.84.16 } \\
2\end{array}$ & $-1,09$ \\
Construção & 90.991 & 113.143 & -22.152 & $\begin{array}{c}2.113 .21 \\
4\end{array}$ & $-1,04$ \\
Indústria & 105.313 & 208.399 & -103.086 & $\begin{array}{c}7.255 .14 \\
7\end{array}$ & $-1,40$ \\
Serviços & 329.217 & 489.676 & -160.459 & 17.838 .1 & $-0,89$ \\
Não identificado & 0 & 54 & -54 & - & - \\
Total & 750.013 & 1.117 .24 & -367.227 & 37.560 .3 & $-0,97$ \\
& & 0 & & 95 & \\
\hline
\end{tabular}

Fonte: CAGED. Dados Setoriais, 2021.

Nota: - sem dados.

Tabela 4.4 - Admissões e desligamentos em junho de 2020 no Brasil, por grandes grupamentos de atividade econômica

\begin{tabular}{lccccc}
\hline Setor & $\begin{array}{c}\text { Admitid } \\
\text { os }\end{array}$ & $\begin{array}{c}\text { Desliga } \\
\text { dos }\end{array}$ & Saldo & Estoque & $\begin{array}{c}\text { Vr. relativa } \\
\text { (\%) }\end{array}$ \\
\hline Agropecuária & $\mathbf{8 7 . 6 5 1}$ & $\mathbf{4 9 . 9 0 4}$ & $\mathbf{3 7 . 7 4 7}$ & $\begin{array}{c}\mathbf{1 . 5 4 7 . 8} \\
\mathbf{1 2}\end{array}$ & $\mathbf{2 , 5 0}$ \\
Comércio & 197.930 & 218.034 & -20.104 & $\begin{array}{c}8.824 .05 \\
8\end{array}$ & $-0,23$ \\
Construção & 119.675 & 103.238 & 16.437 & $\begin{array}{c}2.129 .65 \\
1\end{array}$ & 0,78 \\
Indústria & 150.099 & 155.303 & -5.204 & $\begin{array}{c}7.249 .94 \\
3\end{array}$ & $-0,07$ \\
Serviços & 388.446 & 443.930 & -55.484 & $\begin{array}{c}17.782 .6 \\
98\end{array}$ & $-0,31$ \\
Não identificado & 0 & 21 & -21 & - & - \\
Total & 943.801 & 970.430 & -26.629 & 37.533 .7 & $-0,07$ \\
& & & & 66 & \\
\hline
\end{tabular}

Fonte: CAGED. Dados Setoriais, 2021.

Nota: - sem dados. 
O mercado de trabalho, nos diversos setores da atividade econômica, começou a melhorar significativamente a partir de julho de 2020, com praticamente todos os setores com desempenho positivo, ou seja, mais admissões do que desligamentos ou, ainda, com geração de empregos. O setor de construção voltou a crescer, enquanto que o setor de serviços foi o único que apresentou saldo ligeiramente negativo (Tabela 4.5).

Tabela 4.5 - Admissões e desligamentos em julho de 2020 no Brasil, por grandes grupamentos de atividade econômica

\begin{tabular}{lccccc}
\hline Setor & $\begin{array}{c}\text { Admitid } \\
\text { os }\end{array}$ & $\begin{array}{c}\text { Desliga } \\
\text { dos }\end{array}$ & Saldo & Estoque & $\begin{array}{c}\text { Vr. relativa } \\
\text { (\%) }\end{array}$ \\
\hline Agropecuária & 77.693 & 53.710 & 23.983 & $\begin{array}{c}1.571 .79 \\
5\end{array}$ & 1,55 \\
Comércio & 251.880 & 225.173 & 26.707 & $\begin{array}{c}8.850 .76 \\
5\end{array}$ & 0,30 \\
Construção & 145.628 & 103.915 & 41.713 & $\begin{array}{c}2.171 .36 \\
4\end{array}$ & 1,96 \\
Indústria & 211.564 & 159.307 & 52.257 & $\begin{array}{c}7.302 .20 \\
0\end{array}$ & 0,72 \\
Serviços & $\mathbf{4 6 1 . 9 5 6}$ & $\mathbf{4 6 8 . 8 2 8}$ & $\mathbf{- 6 . 8 7 2}$ & $\mathbf{1 7 . 7 7 5 .}$ & $\mathbf{- 0 , 0 4}$ \\
Não identificado & 0 & 97 & -97 & - & - \\
Total & 1.148 .72 & 1.011 .03 & 137.691 & $\begin{array}{c}37.671 .4 \\
5\end{array}$ & 0,37 \\
\hline
\end{tabular}

Fonte: CAGED. Dados Setoriais, 2021.

Nota: - sem dados.

\section{A GEOGRAFIA DO EMPREGO E DO DESEMPREGO NO BRASIL DURANTE O ANO DE 2020 NO CONTEXTO DA PANDEMIA DE COVID-19}

Quando consideramos a escala nacional, percebemos que, apesar da pandemia e da importância, sob o ponto de vista social, do saldo obtido em 2020, a geração de empregos ficou em percentuais muito baixos entre os meses de janeiro e dezembro (Tabela 6$)-142.690$ postos de trabalho criados $(0,37 \%)$. 
Tabela 4.6 - Geração de empregos entre janeiro e dezembro de 2020 no Brasil, por grandes grupamentos de atividade econômica

\begin{tabular}{lccccc}
\hline Setor & $\begin{array}{c}\text { Admitid } \\
\text { os }\end{array}$ & $\begin{array}{c}\text { Desliga } \\
\text { dos }\end{array}$ & Saldo & Estoque & $\begin{array}{c}\text { Vr. relativa } \\
\text { (\%) }\end{array}$ \\
\hline Agropecuária & 840.870 & 779.233 & 61.637 & 1.548 .71 & 4,14 \\
Comércio & 3.557 .53 & 3.549 .40 & 8.130 & 9.325 .48 & 0,09 \\
& 4 & 4 & & 9 & \\
Construção & 1.570 .83 & 1.458 .66 & 112.174 & 2.279 .09 & 5,18 \\
Indústria & 5 & 1 & & 9 & \\
& 2.597 .97 & 2.502 .38 & 95.588 & 7.605 .34 & 1,27 \\
Serviços & 1 & 3 & & 5 & \\
& 6.599 .01 & 6.731 .59 & -132.584 & 18.195 .9 & $-0,72$ \\
Não identificado & 1 & 5 & & 19 & - \\
Total & 0 & 2.255 & -2.255 & - & - \\
& $\mathbf{1 5 . 1 6 6 .}$ & $\mathbf{1 5 . 0 2 3 .}$ & $\mathbf{1 4 2 . 6 9 0}$ & $\mathbf{3 8 . 9 5 2 .}$ & $\mathbf{0 , 3 7}$ \\
& $\mathbf{2 2 1}$ & $\mathbf{5 3 1}$ & & $\mathbf{3 1 3}$ & \\
\hline
\end{tabular}

Fonte: CAGED, 2021. Dados com ajustes declarados até dezembro de 2020. Nota: - sem dados.

Os setores de serviços e comércio foram os que mais perderam postos durante a pandemia. Entre janeiro e dezembro de 2020, mais de seis milhões de trabalhadores foram desligados no setor de serviços e mais de três milhões, no comércio. $O$ saldo do emprego ficou negativo no setor de serviços durante $o$ período analisado (Gráfico 4.4). 
Gráfico 4.4 - Saldo do emprego no Brasil entre janeiro e dezembro de 2020

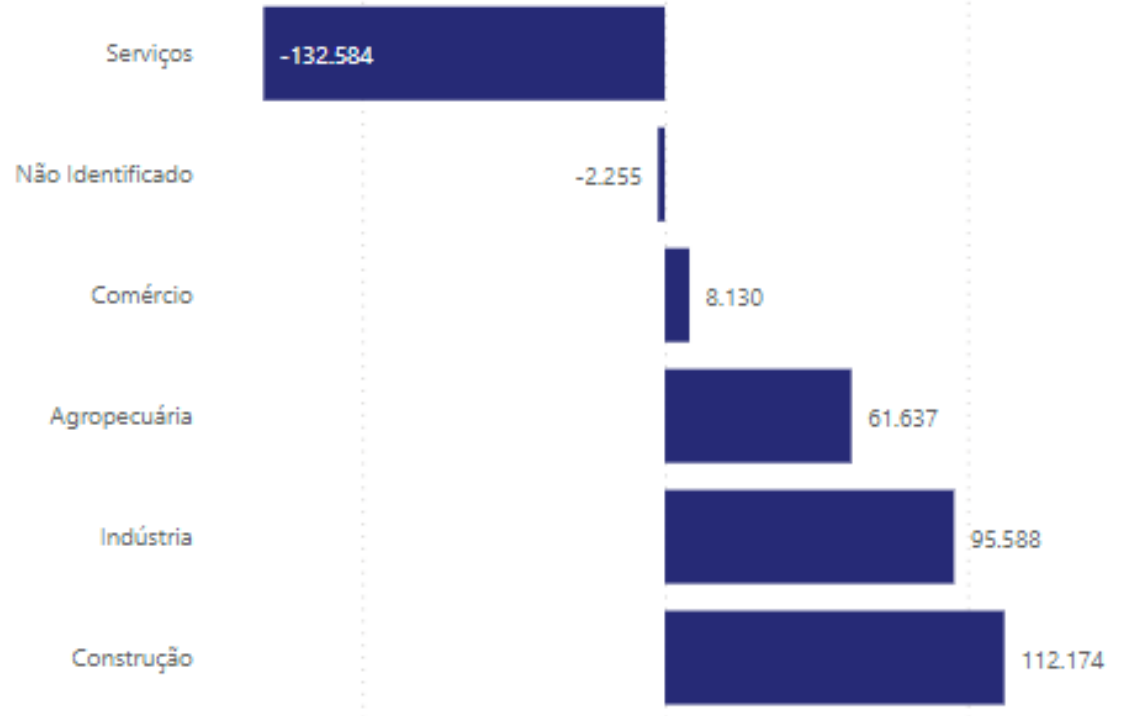

Fonte: CAGED. Dados Setoriais, 2021.

Mas, conforme veremos, houve forte variação regional quando analisamos o emprego e o desemprego no Brasil, com regiões apresentando saldo positivo em todos os setores, enquanto outras tiveram forte queda no setor de serviços, no comércio ou mesmo em ambos. Em dezembro de 2020, 0 estoque de empregos no país ficou em 38.954.340 postos, distribuídos nas cinco macrorregiões brasileiras (Tabela 4.7).

Tabela 4.7 - Estoque do emprego nas macrorregiões brasileiras em dezembro de 2020

\begin{tabular}{lc}
\hline Região & Estoque \\
\hline Norte & 1.843 .34 \\
& 1 \\
Nordeste & 6.388 .78 \\
& 6 \\
Centro-Oeste & 3.312 .98 \\
& 5 \\
Sudeste & 20.076 .8 \\
& 42 \\
Sul & 7.332 .38 \\
& 6 \\
Total & $\mathbf{3 8 . 9 5 4 .}$ \\
& $\mathbf{3 4 0}$ \\
\hline
\end{tabular}


Fonte: CAGED. Dados Setoriais, 2021.

\section{Saldo do emprego nas cinco macrorregiões brasileiras}

A variação do emprego na região Norte seguiu a tendência apresentada pelo país como um todo, ou seja, saldo positivo em janeiro e fevereiro de 2020, saldo negativo entre os meses de março e junho e recuperação nos demais meses do ano. Conforme nos mostra o Gráfico 4.5, apesar da oscilação negativa durante os meses mais críticos, a região fechou o ano com saldo positivo em todos os setores da atividade econômica.

Gráfico 4.5 - Saldo do emprego na região Norte do país entre janeiro e dezembro de 2020

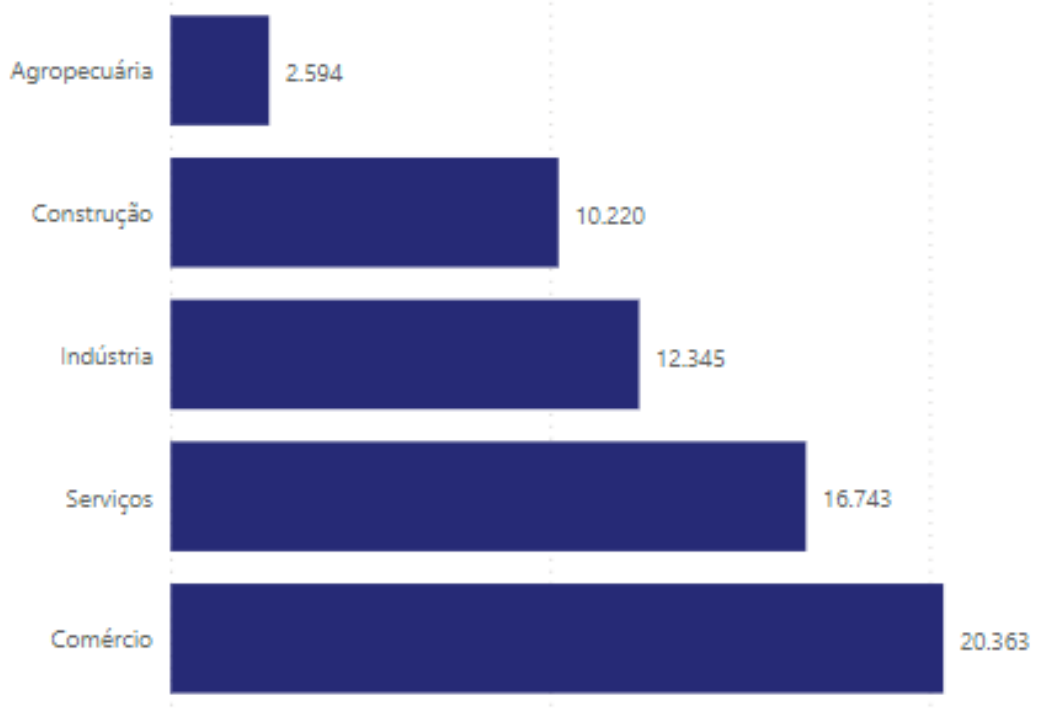

Fonte: CAGED. Dados Setoriais, 2021.

Sabidamente, a região Nordeste é famosa por conter diversas atrações turísticas e oferecer serviços relacionados ao turismo, como na organização de viagens, operações turísticas, mercado hoteleiro sempre dinâmico etc. A pandemia afetou consideravelmente empresas e trabalhadores dessas áreas.

O serviço de cobrança para clientes também emprega muitos trabalhadores na região. Esses trabalhadores fazem parte do grupamento de atividades ligadas às atividades administrativas e serviços complementares, de 
acordo com a Classificação Nacional de Atividades Econômicas (IBGE, 2021). O setor também é caracterizado por conter altos índices de serviços terceirizados.

No conjunto, essas características explicam, ao menos em parte, porque o setor de serviços apresentou saldo negativo entre todos os setores de atividade econômica considerados na análise para a região Nordeste (Gráfico 4.6). Somente no setor de serviços, 808.536 trabalhadores perderam o emprego entre janeiro e dezembro de 2020 na região.

Gráfico 4.6 - Saldo do emprego na região Nordeste do país entre janeiro e dezembro de 2020

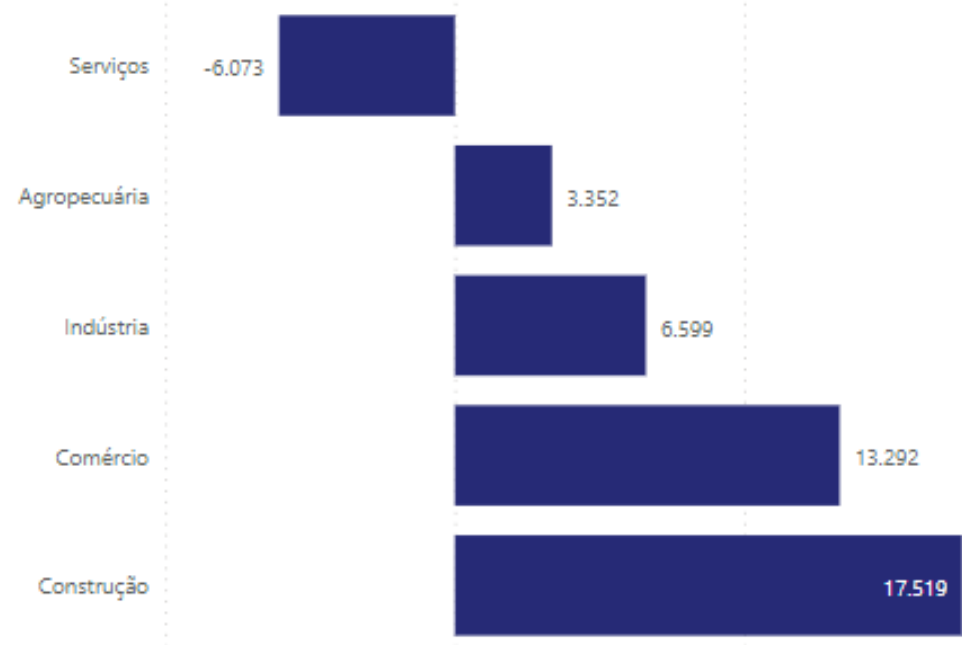

Fonte: CAGED. Dados Setoriais, 2021.

As regiões Centro-Oeste e Sul também apresentaram saldo negativo somente no setor de serviços, mas em quantitativo bastante menor quando comparadas à região Nordeste e, sobretudo, Sudeste, conforme observamos nos Gráficos 4.7 e 4.8. 
Gráfico 4.7 - Saldo do emprego na região Centro-Oeste do país entre janeiro e dezembro de 2020

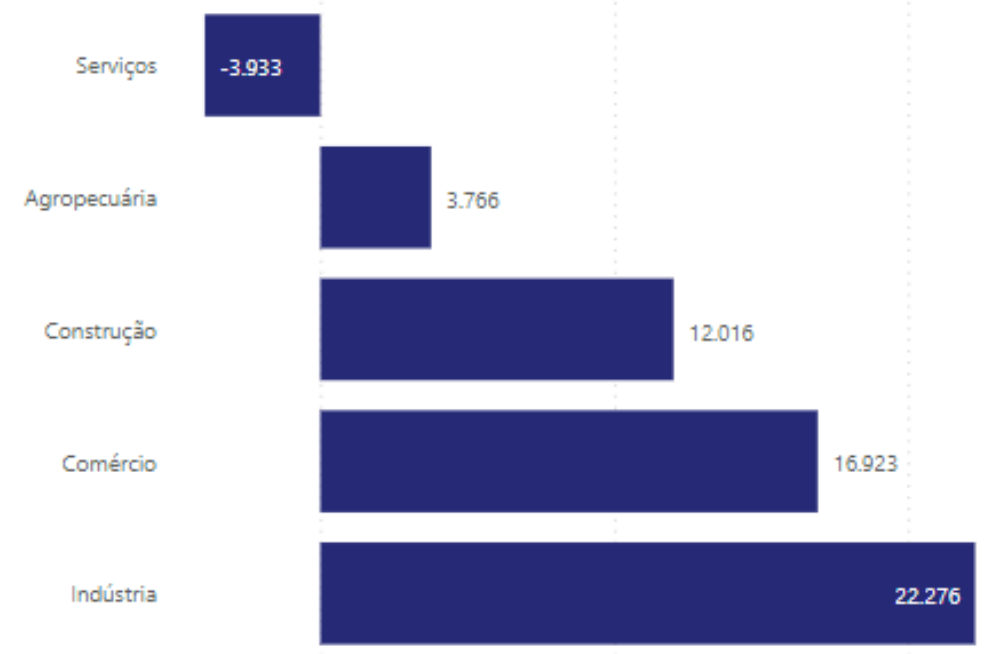

Fonte: CAGED. Dados Setoriais, 2021.

Gráfico 4.8 - Saldo do emprego na região Sul do país entre janeiro e dezembro de 2020

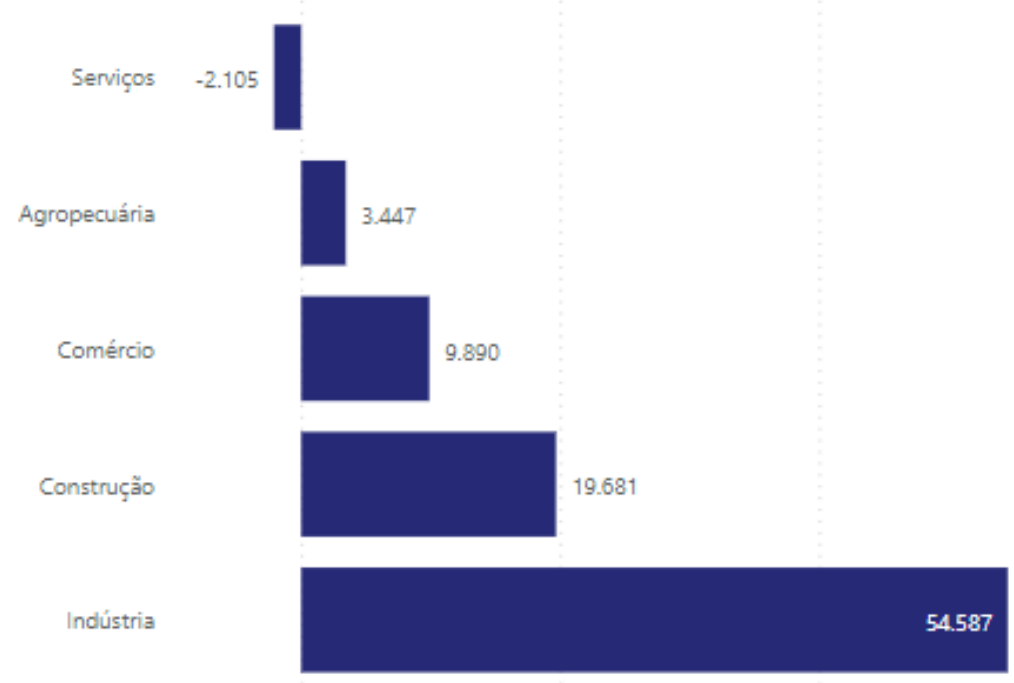

Fonte: CAGED. Dados Setoriais, 2021.

O grande destaque ficou realmente com a região Sudeste, na qual 8.013.789 trabalhadores perderam o emprego entre os meses de janeiro e dezembro de 2020; além disso, a região foi a única a apresentar saldo negativo tanto no setor de serviços quanto nos setores de comércio e indústria (Gráfico 4.9). Para ter uma ideia, considerando todos os trabalhadores que ficaram 
desempregados durante a pandemia no Sudeste, $84,7 \%$ eram dos setores de serviços, comércio e indústria.

Gráfico 4.9 - Saldo do emprego na região Sudeste do país entre janeiro e dezembro de 2020

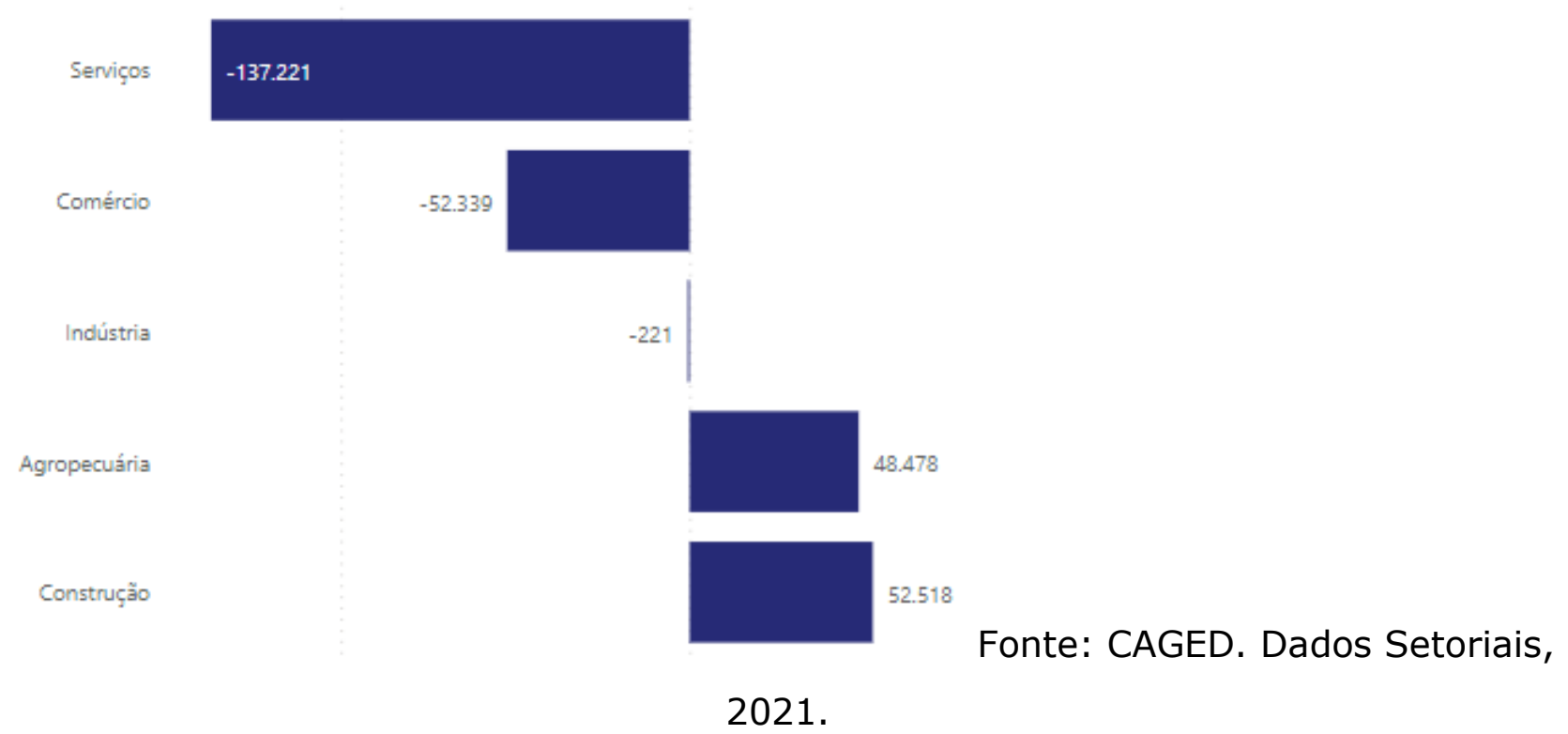

\section{ANÁLISE DO DESEMPREgO NA INDÚSTRIA AUTOMOBILÍSTICA E O FECHAMENTO DE FÁBRICAS DAS MONTADORAS NO BRASIL: DINÂMICAS SOCIOESPACIAIS A PARTIR DA RELAÇÃO GLOBAL-LOCAL E VICE-VERSA}

Agora que já analisamos as transformações no mercado de trabalho considerando a ampla escala nacional e a escala das macrorregiões brasileiras, vamos nos dedicar neste momento à análise específica das mudanças no emprego e desemprego em um determinado setor e suas manifestações nos diferentes lugares. Com o objetivo de demonstrar que não é correto atribuir apenas à pandemia do coronavírus as mazelas do desemprego nos diferentes setores da atividade econômica no Brasil, vamos analisar brevemente as transformações ocorridas no setor automobilístico à luz dos insights provenientes da geografia econômica e, de maneira incipiente, da geografia do 
trabalho. Veremos que, a partir da análise das transformações na indústria automobilística, à luz desses conhecimentos, seus conceitos e teorias, é possível realizar reflexões importantes acerca das estratégias das empresas no processo de globalização e do papel dos territórios nacionais nesse contexto.

A pandemia do coronavírus é, ou ainda será por alguns meses de 2021, apenas parte de uma história que nos revela os motivos do emprego e do desemprego em diferentes países, mas é importante ressaltar que não é possível atribuir toda a oscilação nessas variáveis do mercado de trabalho a esse fenômeno. A capacidade política dos governos, a relação entre empresas e governos, o dinamismo tecnológico das empresas etc. também nos ajudam a compreender por que determinados países, economias, empresas e trabalhadores sofreram menos e outros sofreram mais durante a pandemia. Em outras ocasiões, já justificamos o porquê de analisar a indústria automobilística, sua importância econômica e as conexões com outras indústrias (ALVES, 2011, 2016).

Para além da importância econômica e social dessa indústria, as políticas tributárias e nacionais de incentivo à indústria automobilística, associadas às estratégias das multinacionais do setor, nos revelam que as montadoras de automóveis compreendem perfeitamente sua posição e atuação no espaço geográfico, nos diferentes territórios, e, principalmente, que os governos precisam saber coordenar suas ações de modo a não flexibilizar demais suas estruturas regulatórias ou, no outro extremo, estabelecer normas rigorosas demais que desestimulem a atividade empresarial.

A sinergia entre os interesses dos territórios e os interesses das empresas pode ser considerada um acoplamento estratégico (YEUNG, 2015), situação em que os interesses e objetivos de ambas as partes se combinam e resultam em benefícios para territórios e empresas. Quando isso não ocorre, pode acontecer de os governos deixarem de observar o momento e a dinâmica das empresas no espaço geográfico e permitir que os capitais de empresas do setor flutuem ou procurem por novos territórios. 
Ao examinar a dinâmica envolvendo a mobilidade do capital e das commodities, Harvey (2006) deixa evidente a ideia de que o capital é dotado de mobilidade, logo as empresas podem mover-se no espaço com relativa facilidade, já os territórios nacionais não. Da mesma forma, "a mobilidade social e geográfica da força de trabalho pode ser orquestrada de acordo com necessidades específicas" (HARVEY, 2006, p. 382). É justamente nesse sentido que a geografia econômica é uma área do conhecimento extremamente útil para compreender tais transformações. Ela se preocupa com a localização dos vários elementos dos sistemas econômicos, como eles estão conectados no espaço, como eles o produzem e o transformam e quais são os impactos socioespaciais dos processos econômicos (ALVES, 2015).

Outra perspectiva interessante é a da geografia do trabalho, que pode ser entendida como um ramo do conhecimento que procura investigar as mudanças socioespaciais causadas nos mercados de trabalho e as implicações disso para a vida cotidiana de trabalhadores, a sobrevivência das empresas, a atuação dos governos etc., na medida em que todos se relacionam com o trabalho ou devem pensá-lo ou exercê-lo a partir de suas próprias funções e competências.

Para o trabalhador, trata-se de uma relação lógica e inerente à vida em sociedade, pois tem a necessidade de ofertar sua força de trabalho no mercado em troca de um salário, com o objetivo de garantir sua própria sobrevivência e/ou também a de seus dependentes. O trabalho, nesse contexto, é uma categoria universal e sua análise pode ser considerada central para qualquer ciência social. O trabalho, como "condição ontológica humana, [...] torna as pessoas, historicamente, seres sociais" (SOUZA et al., 2016, p.288). A sociedade "entra em contato com a natureza, transformando-a em natureza humanizada, ou segunda natureza, ou seja, natureza produto do trabalho" (SOUZA et al., 2016, p. 289). Em outras palavras, na perspectiva da inerente relação sociedade-natureza, é perfeitamente plausível considerar que, por meio do trabalho, a sociedade transforma a natureza e, dessa forma, a si mesma. Logo, trabalho, capital e indústria são elementos importantes na transformação do 
espaço geográfico, que sofre a influência das transformações tanto da natureza quanto da sociedade.

Na indústria automobilística, as transformações na natureza são notórias, com a matéria-prima (plástico, borracha, metais etc.) se transformando em automóveis, ou seja, natureza humanizada ou transformada. Já as técnicas empregadas na produção, a rotina de trabalho nas fábricas, a relação de emprego, a condição social dos trabalhadores da indústria etc. refletem as transformações da classe trabalhadora ou, de maneira mais abrangente, da sociedade.

No Brasil, conforme afirma Araújo (2007, p. 13), o processo de reestruturação produtiva efetivou-se nos anos 1990; "inicialmente com resistências do empresariado e, depois, imprimindo determinação em enxugar quadros de pessoal mais que implementar novas tecnologias à racionalização da produção e do trabalho". É por esse motivo que defendemos logo no início deste trabalho que a solução mais imediata para os problemas relacionados aos setores da atividade econômica e à pandemia não é a demissão dos trabalhadores ou mesmo o fechamento de fábricas no país.

De acordo com os ensinamentos de Doreen Massey (1982, p. 3), ainda bastante úteis nos dias atuais, "o fechamento de fábricas individuais, até mesmo o declínio de indústrias e regiões inteiras, não é novidade para as economias de mercado. Elas ocorrem mesmo em períodos de crescente prosperidade geral". O anúncio da Ford no Brasil, em janeiro de 2021, é esclarecedor nesse contexto. No dia 11 de janeiro de 2021, ela anunciou o fim das atividades manufatureiras no país e o fechamento de fábricas. Segundo a empresa, tratava-se de uma restruturação de suas operações na região, pois, conforme publicado em seu site no Brasil,

a indústria automotiva global está passando por um processo de transformação impulsionado por novas e emergentes tecnologias em serviços conectados, eletrificação e veículos autônomos, com demandas dos consumidores e itens regulatórios remodelando o mercado. Além disso, a pandemia global do Covid-19 ampliou os desafios do negócio, com persistente capacidade ociosa da indústria e redução das vendas na América do Sul, especialmente no Brasil. 
Diante desse cenário, a Ford anunciou que encerraria as operações brasileiras de produção nas plantas de Camaçari (BA), Taubaté (SP) e Troller (Horizonte - CE) durante 2021. A sede administrativa para a América do Sul em São Paulo será mantida, bem como o Centro de Desenvolvimento de Produto na Bahia e o Campo de Provas, em Tatuí (SP). Segundo a empresa, essas unidades continuarão a trabalhar no desenvolvimento de tecnologias e produtos para a região e outros mercados globais.

O exemplo da Ford é cabal, pois não suscita dúvidas de que o setor automobilístico está se reconfigurando na escala global mais uma vez. As montadoras, como importantes agentes dessas transformações na geografia da indústria automobilística mundial, nos revelam a dinâmica inerente ao processo de globalização, pois atuam localmente para atender a mercados globais ou macrorregionais. Por isso, inserimos essas transformações como representativas das dinâmicas socioespaciais resultantes da relação global-local, e vice-versa.

A decisão tomada pela Ford se trata de um reposicionamento estratégico e seletivo da empresa na escala global, que inevitavelmente gera implicações no lugar. O Brasil, diante de seus problemas políticos, econômicos, sociais, tributários e de redução de renda das famílias, está sendo questionado como importante território para o futuro da indústria. A instabilidade política que se apresenta no país desde 2016, associada a fortes demandas do setor e à pandemia do coronavírus, tem sido utilizada pelos fabricantes como argumento importante para considerar o Brasil um país que ainda precisa melhorar sua competitividade. Assim argumentou o presidente da Associação Nacional dos Fabricantes de Veículos Automotores (Anfavea), Luiz Carlos Moraes, dias depois do anúncio do fim das operações de produção da Ford no Brasil. Em matéria publicada pelo repórter Henrique Gomes Batista, de $O$ Globo, Moraes afirmou que as montadoras não querem subsídios, mas competitividade e reforma tributária. Para o presidente da entidade, dar subsídios para suavizar o tamanho da carga de impostos e buscar corrigir as distorções do sistema tributário brasileiro não é a melhor solução. Moraes compara o sistema tributário brasileiro 
e a política de incentivos por meio de subsídios à Black Friday: "Imposto elevado para dar incentivo como desconto" (BATISTA, 2021). Com o anúncio realizado pela montadora, estimativas do Departamento Intersindical de Estatística e Estudos Socioeconômicos (Dieese) indicam que o fechamento das fábricas da Ford no Brasil irá afetar diretamente mais de cinco mil empregos, além de um efeito cascata em 118,864 mil postos de trabalho, somando diretos, indiretos e induzidos $^{15}$ (DIEESE, 2021).

Mas o problema do desemprego não se limita ao setor automobilístico; outros setores da atividade econômica retratam problemas muito anteriores à pandemia, mais precisamente desde 2015, conforme demonstra a análise de Silva (2021). A propósito, a análise de Ivone Silva deve ser destacada pelo fato de a autora nos alertar que, quando se trata das transformações no mercado de trabalho, o pior ainda está por vir. Para ela, "a sociedade precisa se organizar e tomar as rédeas de seu próprio destino ou então corremos o risco de seguir contando as vítimas da pandemia e do descaso de quem deveria nos liderar nesse momento" (SILVA, 2021).

Assim, constatamos que o fechamento de fábricas da indústria automobilística no Brasil não se limita à pandemia. Discussões sobre a carga tributária, o posicionamento político do governo e as políticas de incentivo no Brasil também se fazem necessárias. É igualmente importante refletir sobre a mobilização da sociedade e a dinâmica entre o local e o global num contexto de transformações futuras impulsionadas pelas flexibilizações, inovações tecnológicas e globalização.

Este trabalho procurou lançar luz sobre alguns pontos no contexto dessas discussões e reflexões bastante abrangentes, mas estamos cientes de que ainda há todo um arcabouço conceitual, teórico, prático etc. a ser explorado e

15 No contexto analisado, emprego induzido se refere a postos de trabalho criados pela montadora, cujos colaboradores admitidos passam a investir ou gastar sua própria renda em bens ou serviços ofertados dentro da mesma comunidade (ou nas proximidades) em que a montadora está instalada. Como exemplo, passam a consumir de lojas e supermercados na localidade, se hospedam em hotéis na região, fazem uso dos serviços locais etc., gerando novas oportunidades de trabalho e emprego. 
analisado. As implicações das mudanças no mercado de trabalho é apenas uma das maneiras para se inserir nessas discussões e buscar identificar as particularidades que compõem as estruturas (econômica, social, jurídicoadministrativa, ambiental, política), que, por sua vez, formam uma totalidade. Isso nos permite dizer que há muito espaço para pesquisas com recortes temáticos, temporais e espaciais bastante distintos, mas que tenham em mente a preocupação social, econômica, ambiental etc. que devemos ter com nosso país, suas regiões e, em particular, as pessoas que vivem em suas localidades, municípios e bairros. Afinal, é a partir dos nossos lugares, do nosso cotidiano nesses espaços e da identidade que criamos com o espaço que nos circunda que a mudança acontece e pode ser incentivada.

\section{REFERÊNCIAS}

ALVES, Alceli Ribeiro. EU enlargement and upgrading in the automotive industry of EastCentral Europe. Londres, 2011. 101 f. Dissertação (Mestrado em Geografia)- Escola de Geografia, Queen Mary University- University of London.

- A indústria automobilística nos países do MERCosul: territórios, fluxos e upgrading industrial. Tese (Doutorado em Geografia)- Universidade Federal do Paraná, Curitiba, 2016.

Geografia econômica e geografia política. Curitiba: Intersaberes, 2015.

ARAÚjO, Silvia Maria de (org.). Trabalho e Capital em trânsito: a indústria automobilística no Brasil. Curitiba: Ed. UFPR, 2007.

BATISTA, Henrique Gomes. Montadoras rebatem Bolsonaro sobre saída da Ford. O Globo. 13/01/2021. Disponível em: https://oglobo.globo.com/economia/montadoras-rebatembolsonaro-sobre-saida-da-ford-nao-queremos-subsidio-mas-competitividade-1-24836495

Acesso em 15 jan. 2021.

BRASIL. Constituição da República Federativa do Brasil. 1988. Disponível em: http://www.planalto.gov.br/ccivil_03/constituicao/constituicao.htm Acesso em: 21 jan. 2021.

. Entra em vigor estado de calamidade pública no Brasil. Disponível em:

https://www.gov.br/planalto/pt-br/acompanhe-o-planalto/noticias/2020/03/entra-em-vigorestado-de-calamidade-publica-no-brasil Acesso em 13 jan. 2021.

CAGED. Programa de disseminação das estatísticas do trabalho (PDET). Disponível em: http://pdet.mte.gov.br/novo-caged?view=default Acesso em 13 jan. 2021.

. Dados setoriais. Disponível em:

https://app.powerbi.com/view?r=eyJrIjoiNWI5NWI0ODEtYmZiYy00Mjg3LTkzNWUtY2UyYjIwMD E1YWI2IiwidCI6IjNIYZkyOTY5LTVhNTEtNGYXOC04YWM5LWVmOThmYmFmYTk30CJ9 Acesso em 14 jan. 2021.

CONGRESSO NACIONAL. Entenda a Tramitação da Medida Provisória. https://www.congressonacional.leg.br/materias/medidas-provisorias/entenda-a-tramitacaoda-medida-provisoria Acesso em: 19 jan. 2021.

DIEESE. Algumas informações sobre o anúncio de fechamento da Ford. Nota à Imprensa, 15/01/2021. 
EBC (EMPRESA BRASIL DE COMUNICAÇÃO). Organização Mundial da Saúde declara pandemia de Coronavírus. 11/03/2021. Disponível em: https://agenciabrasil.ebc.com.br/geral/noticia/2020-03/organizacao-mundial-da-saudedeclara-pandemia-de-coronavirus Acesso em: 15 mar. 2021.

FORD. Ford Avança na Reestruturação da América do Sul. Ford Motor Company. Disponível em: https://www.ford.com.br/reestruturacao-ford-brasilL

Acesso em 15 jan. 2021.

HARVEY, David. Limits to Capital. London: Verso, 2006.

IBGE. Classificação Nacional das Atividades Econômicas. 2021. Disponível em: https://cnae.ibge.gov.br/ Acesso em: 26 jan. 2021.

MASSEY, Doreen. The anatomy of job loss: the how, why and where of employment decline. London: Methuen, 1982.

MINISTÉRIO DA SAÚDE. Dados Covid-19 no Brasil. Disponível em:

https://susanalitico.saude.gov.br/extensions/covid-19_html/covid-19_html.html Acesso em 14 jan. 2021.

MOTA, Camilla Veras. Cobre seu governador: qual a responsabilidade do governo federal no combate à pandemia? BBC Brasil, São Paulo, 2020. Disponível em:

https://www.bbc.com/portuguese/brasil-53244465 Acesso em 21 jan. 2021.

SABINO, Marlla. (2020, setembro, 04) Guedes diz que pandemia da Covid-19 está 'cedendo' e economia, voltando. Isto é. Disponível em: https://istoe.com.br/guedes-diz-que-pandemia-dacovid-19-esta-cedendo-e-economia-voltando/ Acesso em: 27 set. 2021.SEPTR-ME. Nota técnica.

Substituição da captação dos dados do Caged pelo eSocial. Secretaria Especial de Previdência e Trabalho- Ministério da Economia. Disponível em:

http://pdet.mte.gov.br/images/Novo_CAGED/Nota\%20t\%C3\%A9cnica\%20substitui\%C3\%A7 \%C3\%A30\%20CAGED_26_05.pdf_Acesso em 13 jan. 2021.

SILVA, Ivone. Mercado de trabalho, o pior está por vir. 2021. Disponível em:

https://spbancarios.com.br/01/2021/ivone-silva-mercado-de-trabalho-o-pior-esta-por-vir Acesso em: 03 fev. 2021.

SOUZA, Suzane Tosta; SANTOS, Jânio R. D. dos; ROCHA, Fátima C. B.; LEAL, Victor A. S. Revista Pegada, v. 17, n.1, julho 2016. Disponível em: file://C:/Users/92005373/Downloads/4691-15820-1-PB.pdf Acesso em: 20 jan. 2021.

YEUNG, Henry Wai-chung. Regional development in the global economy: A dynamic perspective of strategic coupling in global production networks. Regional Science Policy and Practice, Vol. 7, n.1, p. 1-23, 2015. 


\title{
CAPÍTULO 5 - ASTRONOMIA EM TEMPOS DE PANDEMIA: ALGUNS EVENTOS CELESTES
}

\author{
GERMANO BRUNO AFONSO 16 \\ THAISA MARIA NADAL17
}

O objetivo deste capítulo é salientar como a pandemia do coronavírus pode ser consequência da poluição luminosa e como o confinamento, devido a ela, diminuiu essa poluição. Esse fato permitiu que muitas pessoas, leigas em astronomia, observassem mais os eventos celestes, como a visibilidade da Lua durante o dia, a Superlua e os satélites artificiais, procurando informações sobre esses eventos, que repassamos principalmente pelas redes sociais.

A pandemia da Covid-19 causou mudanças dramáticas nas atividades humanas, em grande parte do mundo. Isso tem sido especialmente verdadeiro durante os chamados períodos de confinamento, quando as atividades locais, regionais ou nacionais e os movimentos de pessoas foram drasticamente restringidos, para reduzir as taxas da transmissão viral. Os detalhes dessas restrições, a extensão e o vigor com que foram aplicadas variaram muito entre diferentes países. Nesse período, muitas fontes de poluição artificiais, relacionadas à atividade econômica, registraram quedas drásticas em sua produção de poluentes.

Esses confinamentos atuam como valiosos "experimentos naturais", permitindo que novas análises sejam conduzidas sobre a relação entre os níveis de atividade humana e os níveis de danos ao meio ambiente, comparando impactos potenciais importantes antes e durante esses períodos. Em resposta à Covid-19, os períodos de confinamento também proporcionaram uma

\footnotetext{
16 Doutor em Astronomia. Professor no Centro Universitário Internacional Uninter.

17 Mestra em Gestão Ambiental. Professora do Centro Universitário Internacional Uninter.
} 
oportunidade única para estudar os impactos da atividade econômica na poluição ambiental, como, por exemplo, nas reduções do dióxido de nitrogênio $\left(\mathrm{NO}_{2}\right)$, da liberação de aerossóis poluentes e da poluição sonora.

O confinamento diminui a poluição luminosa e o brilho do céu noturno de vilas e cidades, principalmente pelos seguintes motivos: diminuiu o tráfego da hora de engarrafamento, assim como a iluminação particular de edifícios e de áreas privativas, as luzes dos veículos, dos prédios de escritórios que fecharam e das reuniões em grande escala, que normalmente exigiriam iluminação extensa, mas foram canceladas.

Como é do conhecimento de muitos astrônomos, o problema da poluição luminosa no céu noturno não é apenas a quantidade de iluminação artificial, mas também a névoa de material particulado atmosférico, existente na poluição do ar, que reflete essa iluminação de volta para o solo.

\section{ILUMINAÇÃO ARTIFICIAL E CORONAVÍRUS}

A poluição luminosa é um problema global, que afeta todos os habitantes do ecossistema, pois a luz noturna é uma fonte de poluição ambiental, que perturba os ritmos biológicos diários (circadiano) e suprime a biossíntese noturna da melatonina (HAIM; ZUBIDAT, 2015). A urbanização global e o desenvolvimento humano, por intervenções antropogênicas, levaram a um aumento dramático na extensão e na intensidade da iluminação artificial ao longo dos séculos XX e XXI (FALCHI et al., 2016).

A origem da pandemia do coronavírus, causador da COVID-19, é zoonótica, sendo o dia-noite circadiano a pista rítmica para os organismos em suas funções corporais sincronizadas. O desenvolvimento para a humanidade intensificou o uso de luz artificial à noite, havendo uma possível influência desse fator antropogênico no surto de coronavírus humano (HCoV).

O uso de luz artificial à noite está aumentando anualmente em $6 \%$ em todo o mundo e aumenta o brilho noturno do céu em 20\% (KHAN et al., 2018). Há, também, uma relação entre as ocorrências de coronavírus e a curva 
ascendente de utilização da luz noturna. A luz artificial da noite influencia a fisiologia e o comportamento do morcego, um conhecido reservatório natural noturno de muitos Coronaviridae. O status de "ameaçado" e "em perigo" da maioria das espécies de morcegos se deve principalmente à destruição de seu hábito e hábitat adequados, predominantemente por meio de iluminação artificial.

O estresse exercido pela luz artificial à noite prejudica as funções corporais, especialmente as características endócrinas, imunológicas, de integração genômica e de ritmo geral de diferentes variáveis fisiológicas e comportamentos em animais noturnos. A luz noturna perturba a sincronização "vírus-hospedeiro" e pode levar à mutação na parte genômica e à eliminação excessiva do vírus (KHAN et al., 2020). Os morcegos são conhecidos por abrigar uma grande variedade de vírus, desde coronavírus a ebolavírus e henipavírus, sem apresentar quaisquer sintomas clínicos das doenças em questão. Sua longa vida pode ser o resultado de um intrincado equilíbrio entre o sistema imunológico do hospedeiro e a infecção por vírus (WYNNE; WANG, 2013).

Em 2020, vários pesquisadores avaliaram o impacto da temperatura e da umidade relativa na transmissão do coronavírus causador da Covid-19 entre as comunidades, levando em consideração fatores de nível comunitário, como dados demográficos, status socioeconômico e status de mobilidade humana. Eles concluíram que temperatura mais alta e umidade relativa mais alta reduzem a transmissão do vírus (WANG et al., 2020). No entanto, o impacto potencial da temperatura/umidade relativa no número reprodutivo efetivo por si só não é forte o suficiente para interromper a pandemia. Portanto, fora dos trópicos, há maior transmissão do vírus da Covid-19 no período de outono/primavera do que na primavera/outono, caracterizando um ritmo cronobiológico anual, atingindo um mínimo no verão e um máximo no inverno. 


\section{A POLUIÇÃO LUMINOSA}

Os efeitos do dióxido de nitrogênio $\left(\mathrm{NO}_{2}\right)$ e dos aerossóis foram muito perceptíveis e facilmente demonstrados, mas os da poluição luminosa provaram ser difíceis de determinar. Por outro lado, os dados terrestres sobre iluminação artificial à noite são limitados em disponibilidade, mas tornam-se muito importantes como fonte de informação sobre esse aspecto da poluição, durante um confinamento.

Para analisar o efeito do confinamento nas emissões de luz urbana em Granada, Espanha, Bustamante-Calabria e sua equipe coletaram dados do solo e de satélites, antes da pandemia e durante o confinamento induzido pela Covid19 na cidade, de 14 de março a 31 de maio de 2020. Na Espanha, o confinamento geral começou em 14 de março de 2020, para neutralizar uma taxa acentuada de propagação da pandemia (BUSTAMANTE-CALABRIA et al., 2021). Os pesquisadores descobriram que esse confinamento estava associado a uma redução na poluição luminosa, devido a menos emissões de luz da cidade e menor conteúdo de aerossol no ar, causando menos dispersão de luz. O conteúdo do aerossol tem origem na atividade humana e sua redução está, portanto, diretamente relacionada ao confinamento.

Uma descoberta importante foi que houve uma redução nas atividades humanas, ao ar livre, em mais de $90 \%$ durante o confinamento, mas não na produção de luz da cidade, que foi reduzida em apenas metade desse valor. Em outras palavras, grande parte da iluminação é ligada à noite, independentemente se a área iluminada estiver em uso ou não. BustamanteCalabria e sua equipe concluíram que as emissões noturnas da cidade são dominadas por iluminação permanente que não responde ao comportamento real de seus cidadãos e que isso mostra um desperdício de energia e recursos, além de ser uma fonte de frustração para muitos astrônomos amadores (BUSTAMANTE-CALABRIA et al., 2021). Eles encontraram uma correlação entre a abundância de material particulado atmosférico e o brilho do céu, de modo 
que, quanto mais poluída for a atmosfera, mais brilhante será o céu noturno urbano, dificultando as observações astronômicas.

A estação em que a concentração de material particulado atmosférico foi medida estava localizada a cerca de um quilômetro de distância do local de medição do brilho do céu e ambos os locais tinham altitudes iguais. Essa descoberta corrobora pesquisas anteriores, que afirmam que o brilho do céu visto perto do centro de uma cidade aumenta com o conteúdo de aerossol atmosférico, sendo um fator tanto do conteúdo do aerossol quanto da hora desde o início da noite.

Eles tiveram de desvendar a relação entre os níveis mais baixos de poluição por partículas na dispersão de luz no ar e qualquer diminuição na quantidade de iluminação artificial durante a pandemia. Quando verificaram essas variações, os dados revelaram que, durante o confinamento, a produção geral de luz da cidade havia diminuído em cerca de $20 \%$. Isso se devia à redução dos faróis dos veículos e da iluminação privada (particular), além da iluminação ornamental dos monumentos da cidade.

A redução da poluição deveu-se, principalmente, a dois motivos. Primeiramente, isso ocorreu por causa de uma diminuição na luz espalhada devido à presença de menos aerossóis antropogênicos durante o confinamento. A esse respeito, uma correlação é encontrada entre o brilho do céu em várias bandas de comprimento de onda e a concentração de material particulado atmosférico medida dentro da cidade. O outro principal motivo para a redução da poluição luminosa vem de uma diminuição na quantidade líquida de luz emitida pela cidade ao nível de $20 \%$ no visível, provavelmente em decorrência de uma diminuição na iluminação privada dos edifícios, luzes de veículos e iluminação de áreas privadas, observável principalmente no início da noite. Muito tarde da noite, o fluxo da cidade durante o confinamento e antes dele estava quase inalterado (BUSTAMANTE-CALABRIA, 2020).

Para obter um resultado razoavelmente preciso do impacto do confinamento humano na poluição luminosa, o estudo atual combina imagens de satélite com medições locais, no solo, do brilho do céu. 
Em uma hora muito posterior do início da noite, a emissão de luz das cidades é quase inalterada em relação a antes do confinamento, o que explica a falta de diferença significativa com as imagens da madrugada de satélites. Isso também está de acordo com os dados terrestres, ao mesmo tempo que apoia a inadequação dos dados de satélites adquiridos tarde da noite para detectar os efeitos do confinamento.

O satélite Copernicus Sentinel-5P da Agência Espacial Europeia (ESA) tem mapeado a poluição do ar na Europa e na China e os dados mostram uma queda na poluição do ar, pela redução nas concentrações de dióxido de nitrogênio $\left(\mathrm{NO}_{2}\right)$, como a liberada pela indústria, veículos e viagens aéreas. Isso coincide com as medidas de confinamento devido à Covid-19, impostas por governos em todo o mundo. Os dados do satélite Copernicus podem significar céus melhores para as observações dos astrônomos, pois uma redução no dióxido de nitrogênio $\left(\mathrm{NO}_{2}\right)$ aponta para uma redução correlativa na indústria pesada, tráfego terrestre e menos tráfego aéreo deixando rastros no céu (ESA, 2021).

Os satélites da ESA continuam a monitorar os níveis de poluição do ar na Europa e no resto do mundo, fornecendo ainda mais dados sobre os efeitos do confinamento na qualidade do ar.

\section{OBSERVAÇÃo DA LUA DURANTE O DIA}

Desde o início do mês de março, muitas pessoas nos contataram, porque estavam vendo a Lua durante o dia, fato que elas achavam impossível, pois não estavam acostumadas com um céu tão limpo, em pleno centro da cidade. A Lua é considerada o astro da noite; no entanto, algumas vezes, podemos observála em pleno dia.

O aspecto (ou a aparência) da Lua muda a cada dia. Essa mudança é chamada fases da Lua e depende somente da posição relativa entre ela, Terra e Sol. A cada instante, o Sol ilumina a Lua sob um ângulo diferente, à medida que ela se desloca em torno da Terra. A cada dia, vemos a Lua um pouco diferente e, assim, há diversas fases dela. Contudo, na prática, geralmente apenas quatro 
fases lunares recebem denominações especiais: nova, quarto crescente, cheia e quarto minguante.

Contrariamente ao Sol, que produz sua própria luz e é visível somente durante o dia, a Lua pode ser visível de noite ou de dia. Além de um céu sem poluição, para que ela seja visível durante o dia, deve reunir duas condições: a primeira é que ela seja iluminada pelo Sol, sem estar muito próximo dele, e a segunda é que ela esteja acima de nosso horizonte, durante o dia. Tudo depende dos movimentos relativos do Sol, da Lua e da Terra.

Se nunca vimos a Lua durante o dia, pode haver outra explicação, além da poluição do céu: durante o dia, instintivamente protegemos os nossos olhos da luz solar, seja os fechando, seja colocando as nossas mãos sobre eles, para não causar danos. Mas, se olharmos o céu, desviando nosso olhar do Sol, poderemos ver a Lua e mesmo Vênus em pleno dia.

Figura 5.1 - Representação da Lua nova no hemisfério sul

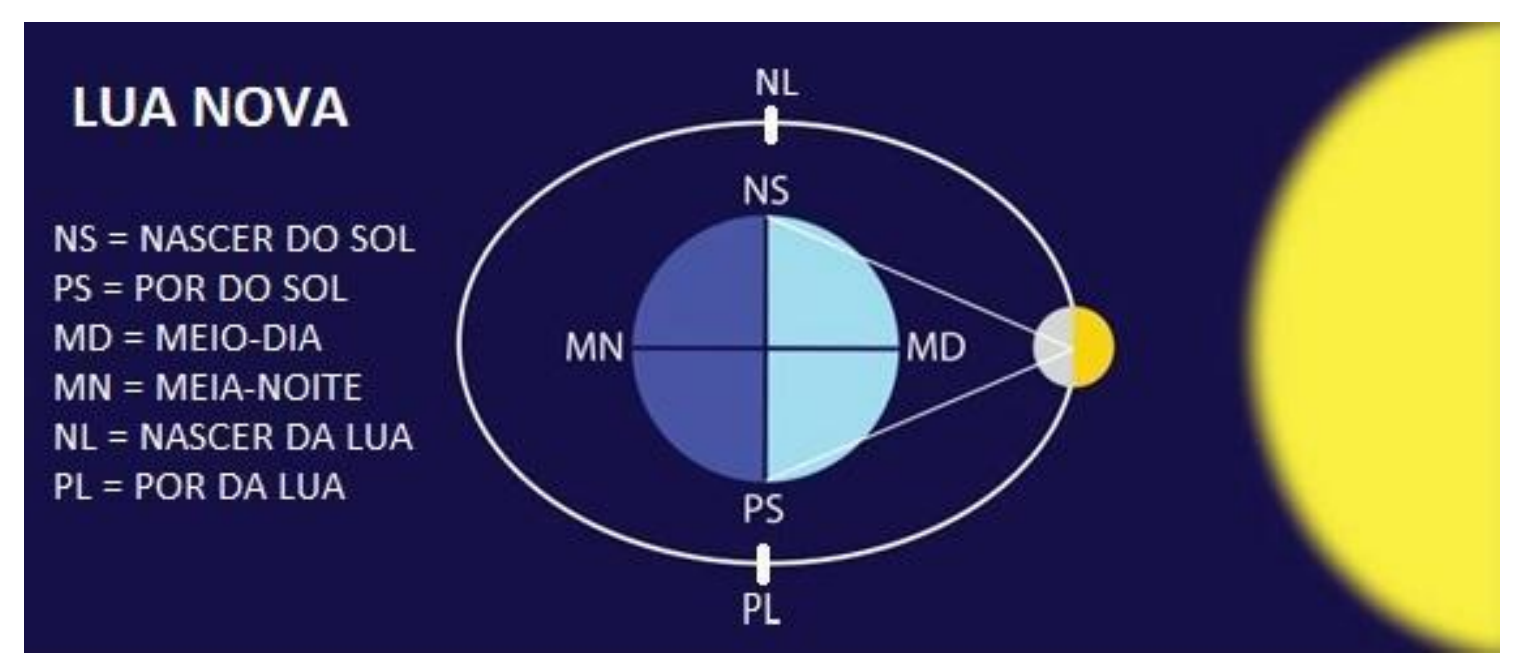

Fonte: Ilustração dos autores 
No dia de Lua nova, ela sempre se encontra na mesma direção do Sol (abaixo dele) em relação ao centro da Terra (conjunção). Ela praticamente nasce $(\mathrm{NL})$ ao nascer do Sol (NS) e se põe (PL) ao pôr do Sol (PS). Ao meio-dia (MD), a Lua está na sua altura máxima, como o Sol (MD), na linha norte-sul (Figura $1)$.

Figura 5.2 - Visibilidade da Lua nova durante o dia

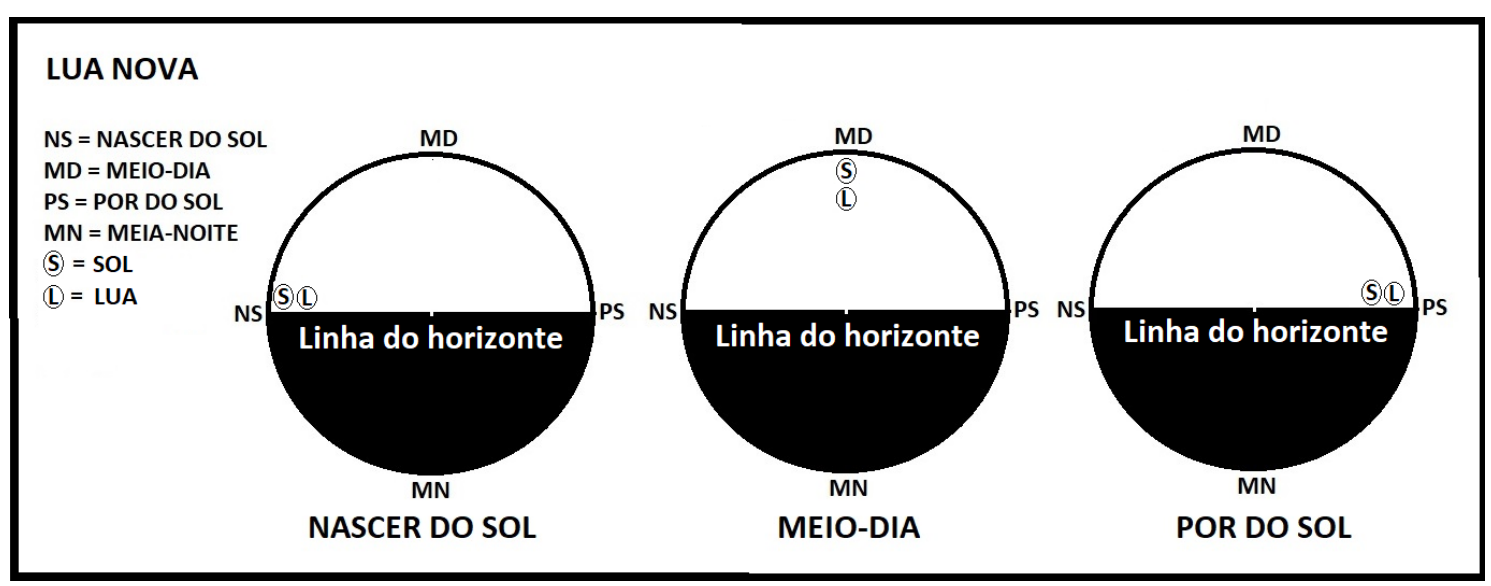

Fonte: Ilustração dos autores

No período de cerca de sete dias no mês, próximo, durante ou logo após o dia da fase de Lua nova, não podemos ver a Lua durante o dia, mesmo ela estando o dia todo acima da linha do horizonte, pois está ofuscada pelo brilho do Sol, que se encontra logo atrás em relação à Terra. Durante a noite, a Lua também não é visível, pois ela se põe com o Sol, ficando abaixo da linha do horizonte (Figura 5.2).

Um eclipse solar ocorre quando o Sol, a Lua (nova) e a Terra ficam bem alinhados e a Lua passa na frente do Sol, vista da Terra. 
Figura 5.3 - Representação da Lua quarto crescente no hemisfério sul

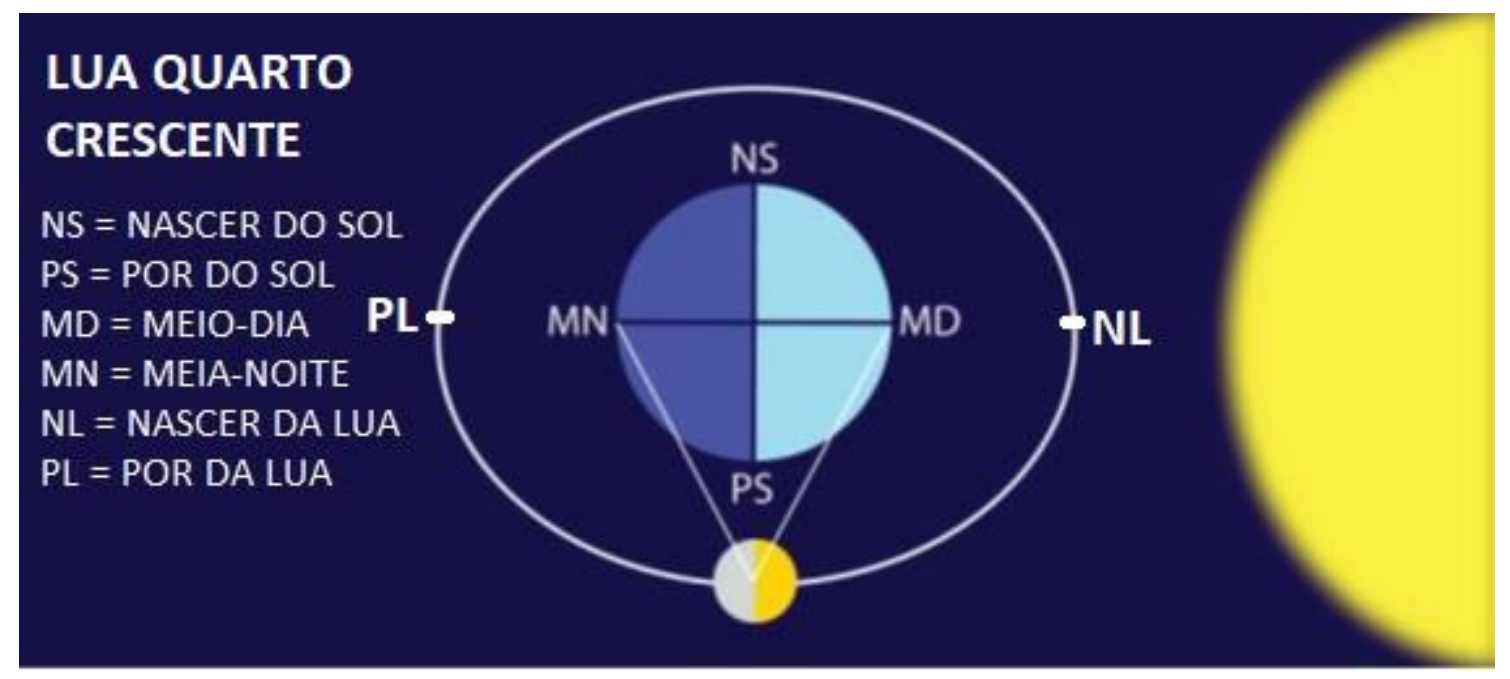

Fonte: Ilustração dos autores

Quando a Lua se afasta da direção do Sol, para se tornar crescente, podemos começar a vê-la durante o dia. No dia de quarto crescente, a Lua se encontra em um ângulo de $90^{\circ}$ graus com o Sol em relação ao centro da Terra. Ela praticamente nasce (NL) ao meio-dia (MD) e se põe (PL) à meia-noite (MN). Ao pôr do Sol (PS), a Lua se encontra em sua altura máxima, na linha norte-sul, durante o dia. Na noite de Lua crescente, metade do disco lunar é visível, parecendo uma letra C. Nessa noite, seu aspecto é de um semicírculo, voltado para o lado oeste, no hemisfério sul (Figura 5.3).

Figura 5.4 - Visibilidade da Lua quarto crescente durante o dia

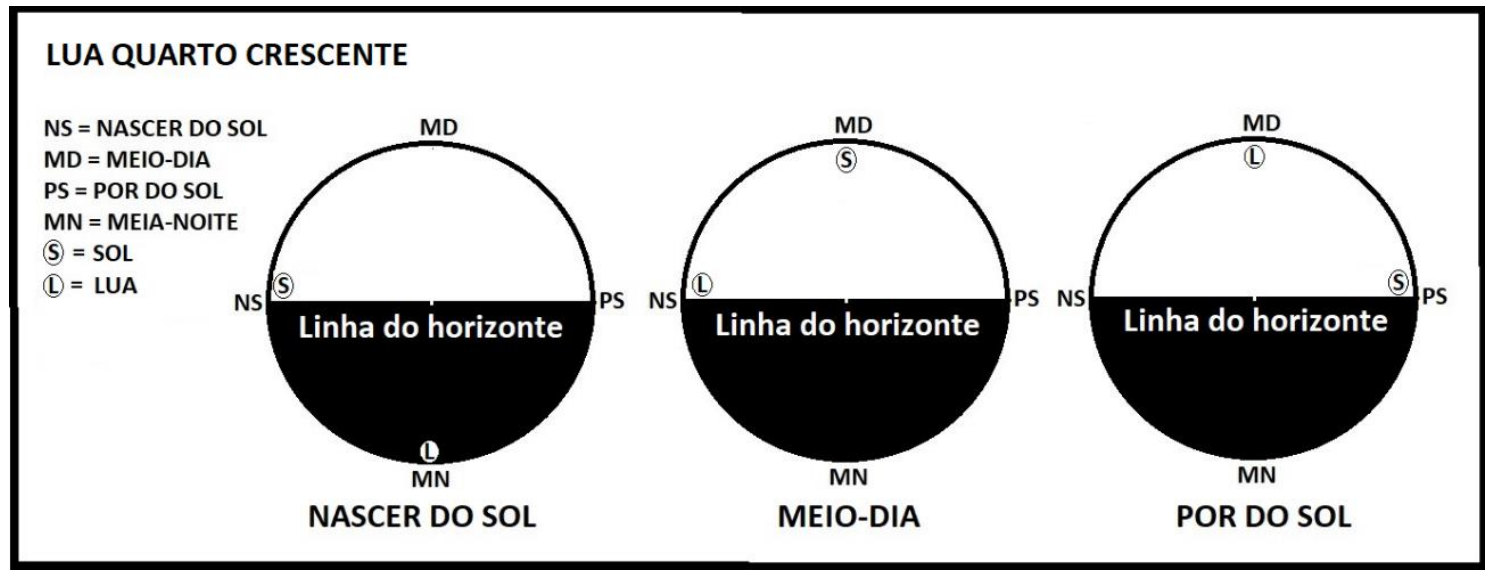

Fonte: Ilustração dos autores 
Na fase quarto crescente, quando o Sol nasce, a Lua ainda não nasceu, pois está abaixo da linha do horizonte. Ela nasce ao meio-dia e se encontra acima da linha do horizonte ao pôr do Sol. Portanto, a Lua quarto crescente é visível durante seis horas durante o dia, quando fica acima do horizonte e é iluminada pelo Sol.

Figura 5.5 - Representação da Lua cheia no hemisfério sul

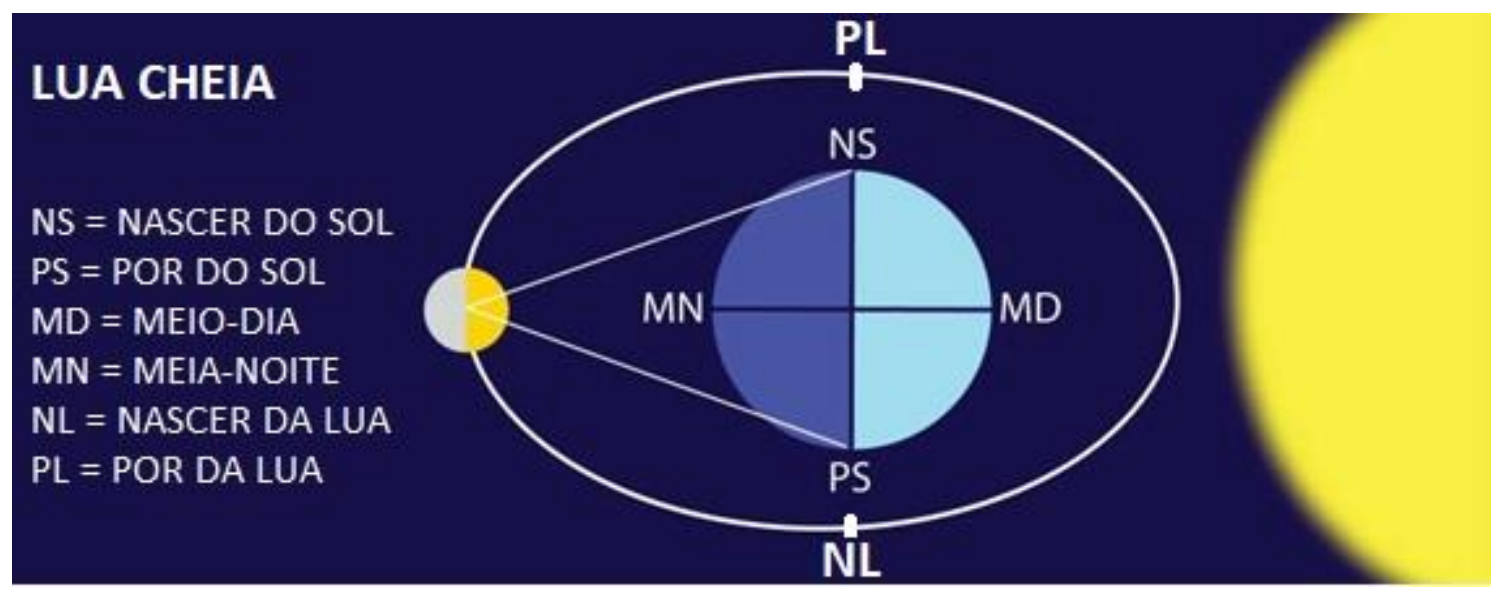

Fonte: Ilustração dos autores

No dia de Lua cheia, ela se encontra na direção oposta à do Sol em relação ao centro da Terra (oposição). O ângulo Sol-Terra-Lua agora é de $180^{\circ}$. Ela praticamente nasce (NL) ao pôr do Sol (PS) e se põe (PL) ao nascer dele (NS). À meia-noite (MN), a Lua está na sua altura máxima, na linha norte-sul. Assim, nesse dia, ela é visível durante toda a noite, pois fica acima da linha do horizonte (Figura 5.5).

Figura 5.6 - Visibilidade da Lua cheia durante o dia

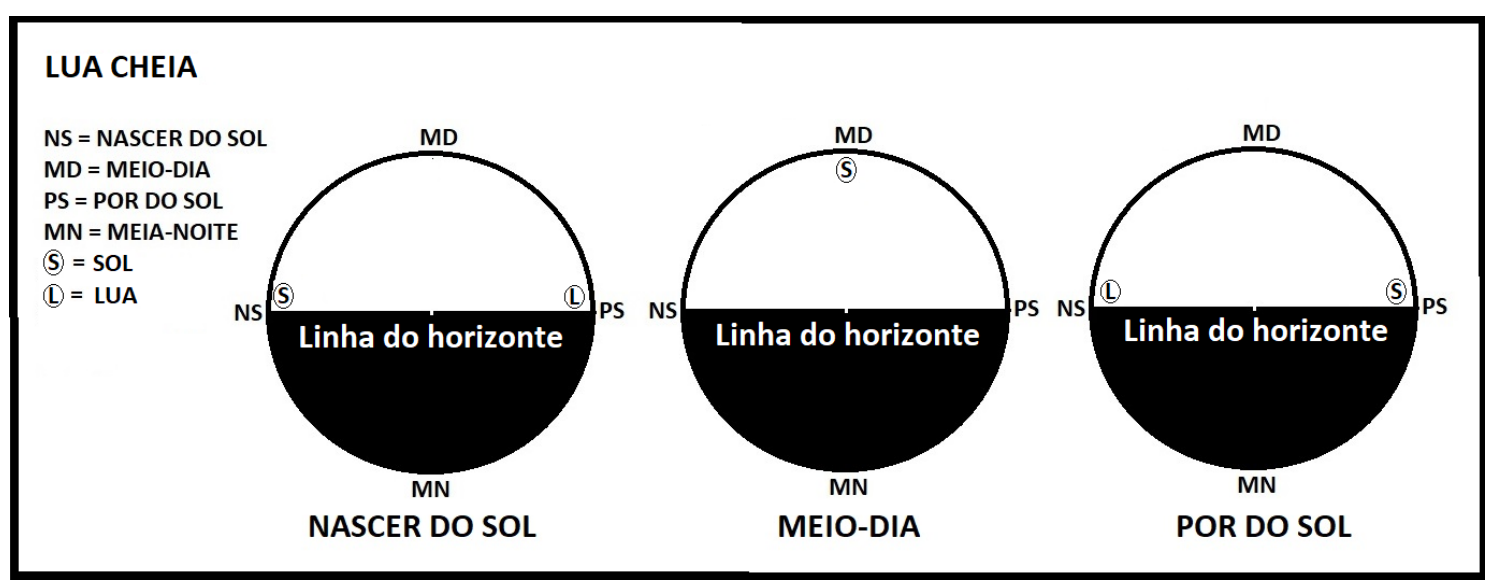


Fonte: Ilustração dos autores

A Lua cheia nasce no lado leste, quando o Sol se oculta no lado oeste. Depois, se põe no lado oeste, quando o Sol nasce no lado leste, ou seja, não podemos observar a Lua durante o dia, pois ela está sempre abaixo da linha do horizonte. No verão, o dia é mais longo que a noite, pois o Sol se oculta mais tarde. Então, é possível ver a Lua cheia surgindo no fim da tarde, do lado oposto ao do Sol (Figura 5.6).

Durante um eclipse lunar, a Lua (cheia), a Terra e o Sol ficam alinhados e a Lua passa na sombra da Terra, vista de nosso planeta.

Figura 5.7 - Representação da Lua quarto minguante no hemisfério sul

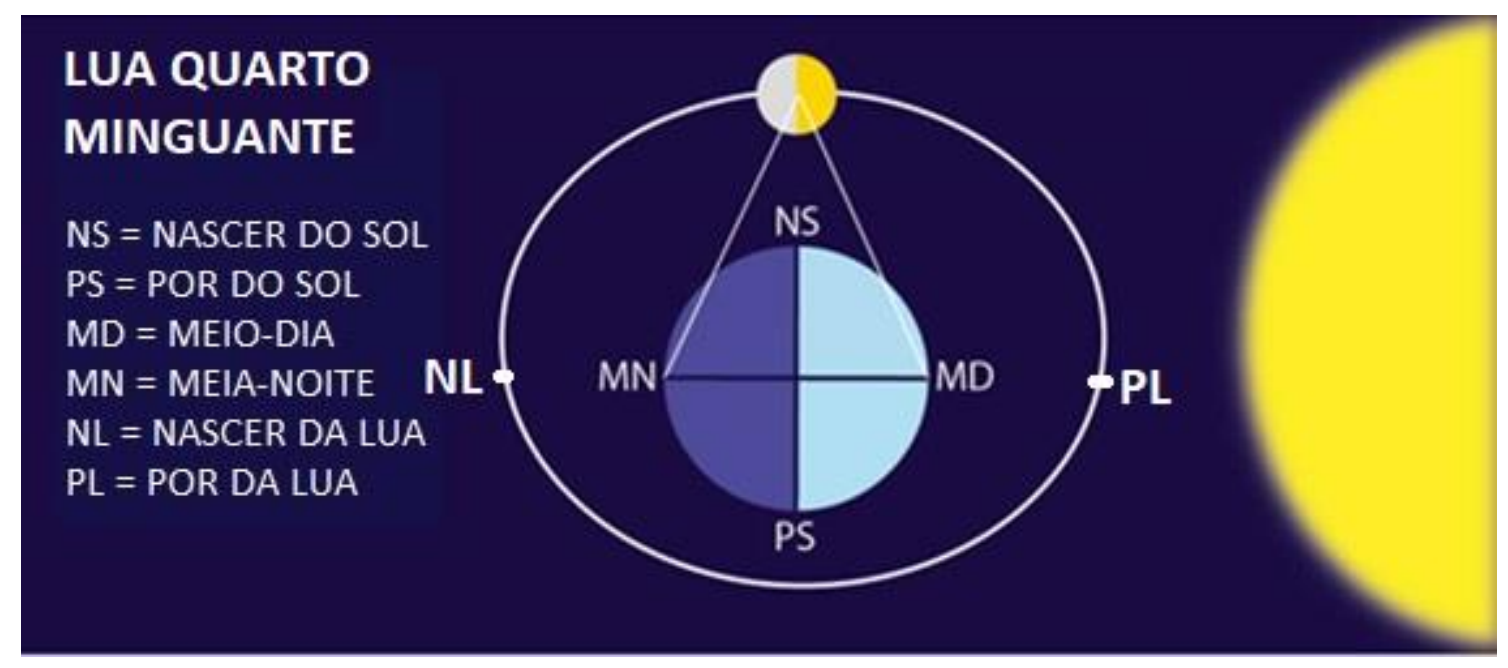

Fonte: Ilustração dos autores

Alguns dias após a Lua cheia, quando começa a se tornar minguante, ela pode ser vista antes do meio-dia, pois nesse período se afasta cada vez mais da direção Terra-Sol. Os dois corpos celestes (Sol e Lua) se encontram suficientemente afastados para que a luz refletida pela Lua não seja ofuscada pela luz emitida pelo Sol. 
No dia da Lua quarto minguante, ela se encontra fazendo um ângulo de $270^{\circ}$ graus com o Sol em relação ao centro da Terra. Ela praticamente nasce à meia-noite (NL) e se põe ao meio-dia (PL). Ao nascer do Sol (NS), a Lua se encontra em sua altura máxima, na linha norte-sul. No dia de Lua minguante, metade do disco lunar é novamente visível, agora parecendo uma letra D. Por isso, o quarto minguante é também conhecido como quarto decrescente no hemisfério sul. Nessa noite, o aspecto da Lua é de um semicírculo, voltado para o lado leste, no hemisfério sul (Figura 5.7).

Figura 5.8 - Visibilidade da Lua quarto minguante durante o dia

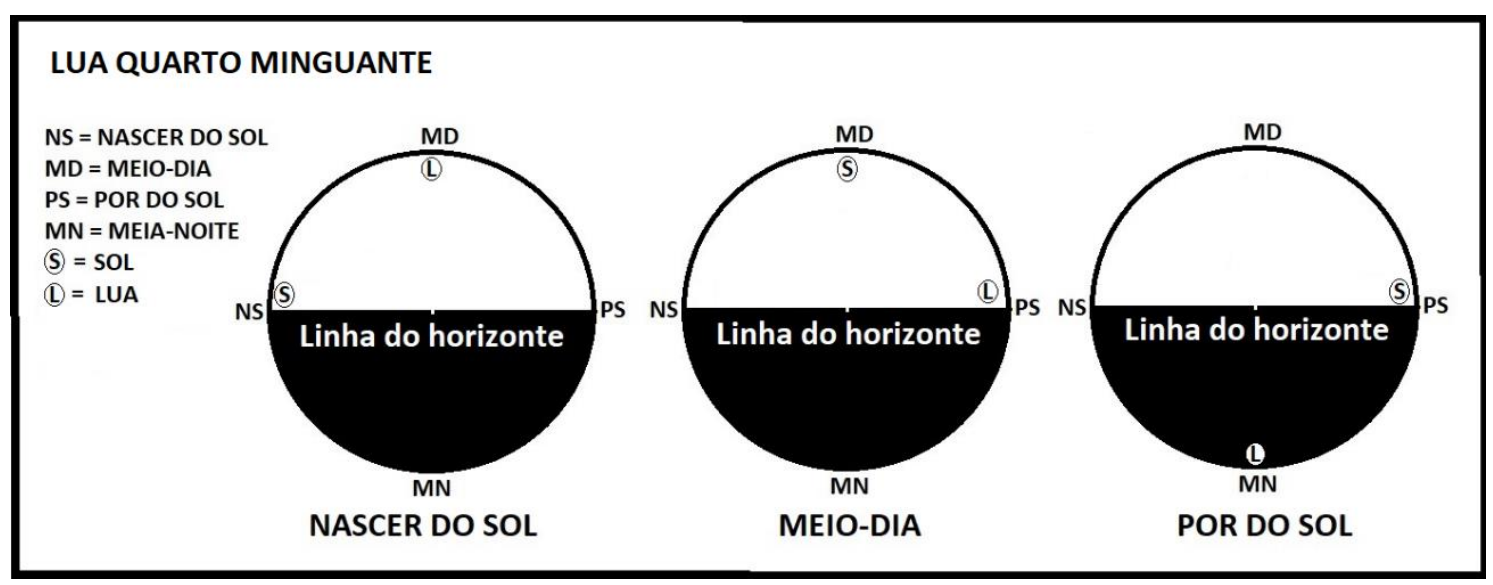

Fonte: Ilustração dos autores

Quando o Sol nasce, a Lua quarto minguante já está acima da linha do horizonte. Ao meio-dia, ela começa a se pôr no lado oeste. Portanto, a Lua na fase quarto minguante fica visível de dia, durante seis horas, quando está iluminada pelo Sol e acima da linha do horizonte. Ao pôr do Sol, ela está bem visível, abaixo do horizonte.

Portanto, a Lua, durante o dia, pode ser vista apenas durante as fases minguante e crescente, bem como em dias próximos a essas fases, não sendo possível vê-la nas fases nova e cheia.

As diferenças de horário quanto ao surgimento da Lua no horizonte explicam-se pelo fato de ela nascer cerca $\mathbf{4 8}$ minutos mais tarde, em média, a cada dia. Portanto, à medida que a posição da Lua em relação aos raios do 
Sol se altera, mudam também as suas fases e o horário de seu aparecimento no horizonte.

\section{A SUPERLUA}

A órbita que a Lua descreve em torno da Terra não é uma circunferência perfeita, mas uma elipse, com a Terra em um dos focos. A Superlua é uma Lua cheia perto do perigeu, que a representa no ponto mais próximo da Terra. Quando a Lua se encontra no apogeu, que é o ponto mais afastado da Terra, ela é chamada Microlua. Frisa-se que a distância da Lua à Terra varia entre 356.000 km (no perigeu) e $406.000 \mathrm{~km}$ (no apogeu).

Em 2020, ocorreram três Superluas, nos dias 9 de março, 8 de abril e 7 de maio.

Figura 5.9 - Visibilidade no perigeu e apogeu da Lua
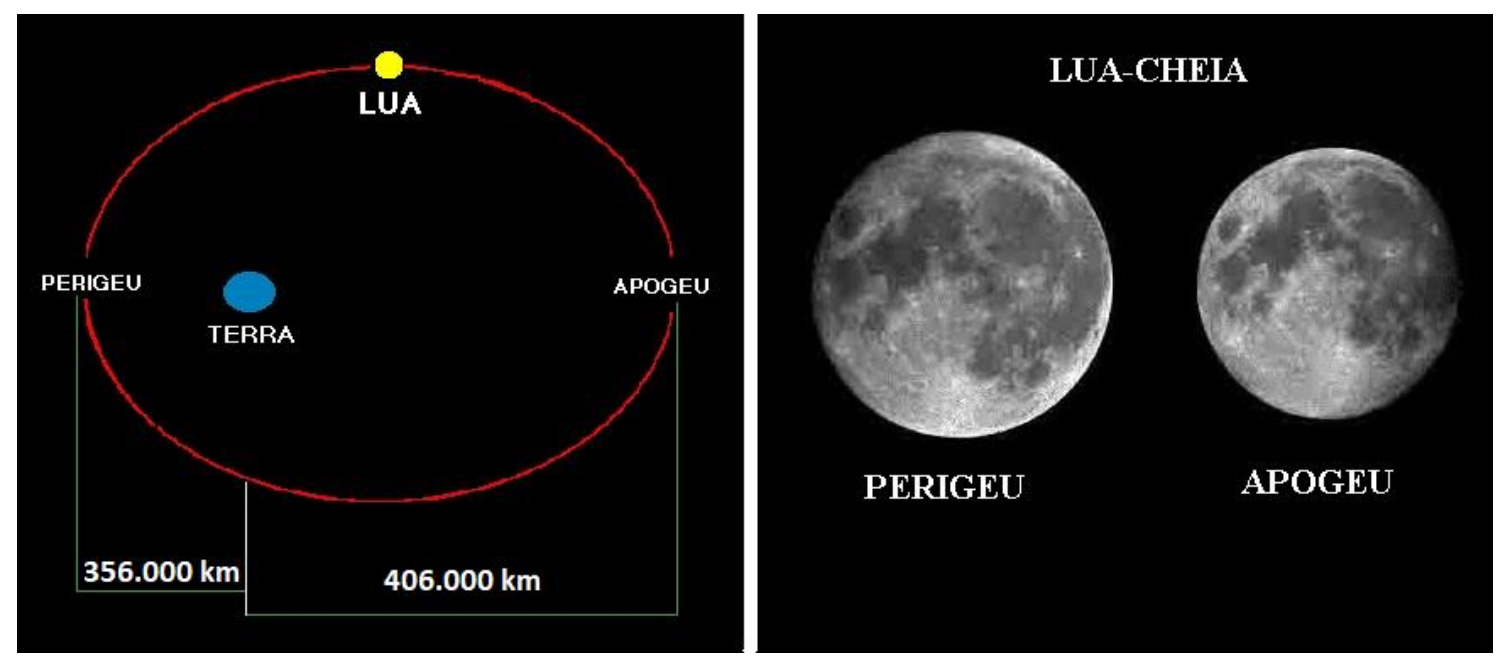

Fonte: Ilustração dos autores 
Uma Superlua (Lua cheia no perigeu) é cerca de $14 \%$ maior que uma Microlua (Lua cheia no apogeu), além de ser cerca de $30 \%$ mais brilhante. 0 diâmetro angular aparente de nosso satélite artificial varia entre 0,48 e 0,56 graus, de acordo com a posição em sua órbita observada da Terra.

A Lua nos parece muito maior quando a observamos perto da linha do horizonte do que quando ela já está mais alta no céu. Isso é explicado como sendo uma ilusão de óptica, pois, se medirmos o diâmetro aparente da Lua nessas duas posições, veremos que o valor é o mesmo. Ela também parece maior se há algum objeto no horizonte perto dela, tal como uma montanha, árvore ou prédio. Quando olhamos para os objetos no horizonte, sabemos que eles não estão distantes de nós. Assim, quando olhamos para a Lua nesse mesmo horizonte, o cérebro supõe que ela está situada à mesma distância que esses objetos, de modo que parece ter um tamanho maior.

A experiência mostra que os objetos nos parecem maiores quando estão abaixo de nossa cabeça do que quando estão acima dela. Isso não ocorre quando a Lua já se encontra alta em relação ao horizonte e nos parece menor. Esse efeito do tamanho da Lua na linha do horizonte acontece tanto no perigeu quanto no apogeu. Consequentemente, a ilusão de óptica não tem nada a ver com o fato de a órbita da Lua não ser circular.

\section{SATÉLITES ARTIFICIAIS}

Um fato que chamou muito a atenção da população, principalmente no primeiro semestre de 2020, foi o aparecimento de objetos luminosos no céu, do lado oeste, logo após o pôr do Sol, que se movimentavam praticamente em fila. Nunca havíamos recebido tantas mensagens de pessoas que gostariam de saber do que se tratava. Tratava-se de satélites Starlink, da empresa SpaceX.

A SpaceX ressalta que o projeto Starlink tem como objetivo desenvolver uma plataforma de satélites de alto desempenho que possibilite à empresa a comercialização de internet ultrarrápida, a todo o planeta, inclusive a locais onde a internet é tradicionalmente muito cara, pouco confiável ou totalmente 
indisponível. Para isso, planeja enviar pelo menos 12.000 satélites ao espaço nos próximos anos. Algumas informações indicam que o Starlink sozinho poderia depositar até 42.000 satélites de órbitas baixas, com uma altitude de $550 \mathrm{~km}$ (MCDOWELL, 2020).

No mês de abril de 2020, a magnitude desses satélites era de 4,63. Esse valor está abaixo da magnitude 6, que é o limite para observação a olho nu, em uma noite já bem escura. Quanto menor é a magnitude, maior é o brilho. Então, com a magnitude 4,63, esses satélites seriam observáveis facilmente em uma noite escura. Como eles são satélites de órbitas baixas, seriam visíveis no início da noite somente se o céu estivesse pouco poluído, como aconteceu naquele período da pandemia (MALLAMA, 2020).

Os entusiastas da astronomia gostaram da experiência de observar (e fotografar) a passagem dos satélites Starlink acima de suas cabeças, compartilhando nas redes sociais muitas fotos das trilhas deixadas pelos satélites no céu durante exposições de longa duração. No entanto, desde quando a SpaceX lançou na órbita da Terra as primeiras 60 unidades da rede Starlink, em maio de 2019, a comunidade científica expressou preocupações, prevendo que as observações astronômicas seriam afetadas pelo brilho das unidades que compõem a constelação desses satélites.

O problema inicial é que, quando os satélites capturam e refletem periodicamente a luz do Sol, agem como pequenos espelhos e interferem nas imagens captadas por telescópios. Em fevereiro de 2020, a União Astronômica Internacional estimou que os rastros das constelações desses satélites serão suficientemente brilhantes para saturar até detectores modernos em grandes telescópios.

Os astrônomos olham para o céu, mas também o escutam com seus gigantescos radiotelescópios, que captam sinais provocados por fenômenos cósmicos, como pulsares e galáxias, que emitem ondas de rádio. No entanto, as frequências emitidas por esses satélites atrapalham as tentativas de ouvir, por meio de radiotelescópios, as ondas de rádio. As emissões desses sistemas estarão presentes dia e noite e sua intensidade poderia não apenas prejudicar 
as observações radioastronômicas, mas também danificar os detectores projetados para receber a radiação de fontes naturais extremamente fracas (SPACEX, 2020).

Em março de 2020, um estudo indicou outro tipo de observação científica que pode ser muito prejudicado pela constelação de satélites artificiais, que é a busca de asteroides próximos à Terra. Um telescópio usado para detectar e estudar objetos próximos ao planeta poderia facilmente confundir unidades do Starlink com rochas espaciais, dando ainda mais trabalho para os astrônomos na tarefa de distinguir cada ponto brilhante nas imagens.

O meteoro que caiu perto de Chelyabinsk, Rússia, em 2013, causando grandes estragos, naturalmente fez muitas pessoas pensarem que poderia ser um companheiro menor do asteroide 2012 DA14, que passou próximo à Terra naquele mesmo dia. Esse asteroide, com um diâmetro de apenas $45 \mathrm{~m}$, pode ser considerado um fragmento, que geralmente vem acompanhado de outros fragmentos menores, espalhados no espaço, praticamente na mesma órbita e separados uns dos outros por longas distâncias. Como resultado, poderia haver uma colisão de um meteoro com a Terra antes, durante ou depois da passagem do asteroide 2012 DA14, da mesma forma como acontece com chuvas de meteoros. Portanto, seria muito interessante procurar fragmentos de asteroides também, próximos dos fragmentos maiores, mais facilmente encontrados (DUHA; AFONSO, 2013). No entanto, esses fragmentos menores, mas perigosos, poderiam ser confundidos, ou não observados, devido à constelação de satélites Starlink.

Para que os Starlink deixem de aparecer em observações astronômicas, a SpaceX adicionou um visor, chamada VisorSat, implantável aos satélites, para impedir que a luz do Sol atinja suas partes mais brilhantes. Segundo a empresa, todos os futuros satélites Starlink terão esses visores, que possuem magnitude 5,92 , tornando-os praticamente invisíveis a olho nu. Os VisorSat têm em média 1,29 magnitude a mais do que os satélites Starlink do projeto original, que tinham magnitude 4,63 e, portanto, eram 31\% mais brilhantes (MALLAMA, 2020). Isso significa que pelo menos uma das preocupações dos astrônomos foi 
aparentemente resolvida: a visão do céu noturno para a população terrestre, sem instrumentos ópticos, não seria mais afetada pelos satélites Starlink.

De acordo com a SpaceX, o objetivo é fazer com que seus satélites tenham pelo menos magnitude 7 (quanto maior a magnitude, menor o brilho). No entanto, para que os objetos fiquem invisíveis a binóculos especiais para astronomia, é necessária uma magnitude 10. Assim, os telescópios ainda seriam prejudicados por essa constelação de satélites artificiais.

\section{CONSIDERAÇÕES FINAIS}

O interesse da população pela astronomia nos motivou a criar um grupo de teleconferência para explicar os eventos celestes que ocorreriam em determinada época do ano, solicitando o envio de fotos de suas observações, que poderiam ser obtidas com um simples celular. Isso faria parte de um projeto de ciência cidadã, que foi criada pela Nasa para levar informação científica para toda a população.

Várias empresas, como a SpaceX, pioneira com seu projeto Starlink, vão encher o céu de aparatos que não têm entre suas prioridades preocupar-se com os danos que causam à ciência ou a detecção de objetos que possam colidir com a Terra. Elas só precisam pedir permissão à Agência de Comunicações dos Estados Unidos, que não tem nada a ver com interesses científicos, astronômicos ou de proteção da Terra, em um espaço que pertence a todos os seres humanos, uma realidade que os astrônomos pretendem mudar para que haja uma regulação global.

\section{REFERÊNCIAS}

BUSTAMANTE-CALABRIA M.; SÁNCHEZ DE MIGUEL A.; MARTÍN-RUIZ S.; ORTIZ J. L.; J. M. VÍLCHEZ J. M.; PELEGRINA A.; GARCÍA A.; ZAMORANO J.; BENNIE J; GASTON K. J. Effects of the COVID-19 lockdown on urban light emissions: ground and satellite comparison. Remote Sens, 13, 258, 2021.

DUHA, J.; AFONSO, G. B. Small asteroid fragments in earth-crossing orbits. In: XIV Latin American Regional IAU Meeting, 2013, Florianópolis, SC. Abstract Book XIV Latin American Regional IAU Meeting. Florianópolis, SC, LARIM, 2013.

ESA (EUROPEAN SPACE AGENCY). Detecting pollution from individual ships from space. Copernicus Sentinel-5P Mapping Portal, 2021 
FALCHI, F.; CINZANO, P.; DURISCOE, D.; KYBA, C. C. M.; ELVIDGE, C. D.; BAUGH, K. et al. The new world atlas of artificial night sky brightness. Sci Adv., 2:e1600377, 2016.

HAIM, A.; ZUBIDAT, A. E. Artificial light at night: melatonin as a mediator between the environment and epigenome. Philos Trans Roy Soc B., 370:20140121, 2015.

KHAN, Z. A.; YUMNAMCHA, T.; MONDAL, G.; DEVI, S. D.; RAJIV, C.; LABALA, R. K.; SANJITA, D. H.; CHATTORAJ, A. Artificial Light at Night (ALAN): A Potential Anthropogenic Component for the COVID-19 and HCoVs Outbreak. Frontiers in endocrinology, 11, 622, 2020.

KHAN, Z. A.; LABALA, R. K.; YUMNAMCHA, T.; DEVI, S. D.; MONDAL, G.; SANJITA, D. H. et al. Artificial Light at Night (ALAN), an alarm to ovarian physiology: a study of possible chronodisruption on zebrafish (Danio rerio). Sci Total Enviro., 629:1407-21, 2018.

MALLAMA, A. Starlink satellite brightness before VisorSat, 2020.Disponível em: https://arxiv.org/abs/2006.08422. Acesso em: 8 fev. 2021.

MCDOWELL, J. The low Earth orbit satellite population and impacts of the SpaceX Starlink constellation. Ap. J. Let., 892, L36, 2020.

SPACEX. Starlink Discussion National Academy of Sciences. April 28, 2020. Disponível em: https://www.spacex.com/updates/starlink-update-04-28-2020/ Acesso em: 21 fev. 2021.

WANG, J.; TANG, K.; FENG, K.; LV, W. High Temperature and High Humidity Reduce the Transmission of COVID-19. New York, NY. Cornell University, 2020.

WYNNE, J. W.; WANG L. F. Bats and viruses: friend or foe? PLoS Pathog, 9:e1003651, 2013. 
121 


\title{
CAPÍTULO 6 - COMPOSTEIRA COMO SUBSÍDIO À ECOALFABETIZAÇÃO NO ENSINO DE GEOCIÊNCIAS: PROPOSTA METODOLÓGICA
}

\author{
LARISSA WARNAVIN 18 \\ NICOLE GERALDINE DE PAULA MARQUES WITT'19
}

\section{INTRODUÇÃO}

Considera-se que a crise ecológica hodierna é resultado de uma dinâmica multicausal de origem antrópica, biótica e abiótica, com a interferência humana nos sistemas naturais protagonizando um processo de megamorte ${ }^{20}$, ou seja, o equilíbrio ecológico planetário depende de fatores diversos e complexos, sendo necessário, para compreendê-lo, contextualizar as relações entre o meio natural e o meio antropizado. A degradação ambiental e o acelerado processo de

18 Doutora em Geografia pela UFPR (2015), com período de estágio no Groupe de Géographie et dHistoire des Territoires da École des Hautes Études en Sciences Sociales (2013). Mestra em Geografia pela UFPR (2010). Bacharela e licenciada em Geografia pela UFPR (2007). Tem experiência na área de geografia física (hidrologia e gestão de bacias hidrográficas, clima urbano e riscos socioambientais); história e filosofia da ciência; educação ambiental e ensino de geociências. Foi docente na educação básica. Atualmente, é integrante do corpo docente do curso de Licenciatura e Bacharelado em Geografia do Centro Universitário Internacional Uninter. Atua também com gestão de projetos, design educacional e edição de materiais didáticos.

19 Bacharela e licenciada em Ciências Biológicas pela UFPR (2010). Especialista em Educação, Meio Ambiente e Desenvolvimento pela mesma instituição (2012). Especialista em Inovação e Tecnologia na Educação pela UTFPR (2020). Tem experiência na área de botânica, com ênfase em fisiologia vegetal, atuando principalmente na propagação vegetativa de espécies de interesse para a conservação de áreas degradadas e de interesse medicinal. Trabalhou também com peixes e aves marinhas, os quais constituíram a sua pesquisa monográfica. Atualmente, é professora do Ensino Médio no Colégio Nossa Senhora Medianeira e integrante do corpo docente da Área de Geociências (cursos de Licenciatura e Bacharelado em Ciências Biológicas e Geografia) do Centro Universitário Internacional Uninter, compondo o Grupo de Pesquisa Atlas Geociências. Atua também com produção e edição de materiais didáticos para a educação básica e ensino superior.

20 Diz respeito à morte em massa de inúmeras espécies, podendo chegar à extinção (MORIN, 2010). 
desequilíbrio ecossistêmico resultado da interação sociedade-ambienteindivíduo podem ter como consequência a extinção da vida.

A sociedade do capital continua expandindo seus objetivos de crescimento econômico, buscando administrar a natureza apenas de forma utilitária e causando devastação. Há pelo menos meio século, cientistas e comunidades do mundo todo vêm alertando sobre os perigos do desequilíbrio ecológico e a dependência desse equilíbrio para que a vida continue existindo tal como se apresenta. Não fossem apenas fauna, flora, solos, corpos hídricos e atmosfera afetados pela ação humana, no rastro dos impactos antrópicos no ambiente estão a desinformação, a miséria e as patologias, sendo necessário cada vez mais ampliar e aperfeiçoar os mecanismos de ensino e de divulgação científica para auxiliar na mitigação dos impactos e, talvez, minimizá-los.

Desde o início do ano de 2020, o planeta passa por uma grande crise sanitária e civilizatória agravada pela pandemia da Covid-19. Esse acontecimento trouxe à tona a importância de um ambiente equilibrado para que haja vida no planeta. A causa primária da infestação pelo coronavírus, possivelmente, seja a ação predatória na fauna silvestre por populações humanas, um fato local que atingiu proporção global e estabeleceu um cenário que extrapola a questão ambiental e revela nuanças da cultura, política, ética e a importância de uma alfabetização ecológica, a qual "permita estabelecer as relações mútuas e influências recíprocas entre as partes e o todo em um mundo complexo" (MORIN, 2011, p.16).

Todo processo de alfabetização envolve o contato com uma linguagem que dê subsídios ao indivíduo para se relacionar com o mundo; dessa forma, a ecoalfabetização ou alfabetização ecológica busca apresentar os princípios ecológicos ao indivíduo para que ele possa acessar a linguagem da natureza. Para as geociências, essa linguagem está relacionada às representações dos padrões da natureza e dos sistemas naturais, daí a importância das ciências naturais no processo de ecoalfabetização, para que as informações oferecidas sejam capazes de proporcionar ao indivíduo a organização dos conceitos ecológicos como pressupostos para uma cidadania planetária. 
Aproveitando o ensejo da pandemia e o aumento do uso das redes sociais, professoras utilizaram uma fanpage da Área de Geociências do Centro Universitário Internacional Uninter e realizaram uma sequência de lives que atingiram parte da comunidade acadêmica; nelas, utilizando o experimento da montagem e manutenção de uma composteira doméstica, foram explorados conceitos das ciências naturais, pautados em princípios ecológicos. (WARNAVIN. WITT. 2020).

Os conteúdos acadêmicos formais continuaram na plataforma do Ambiente Virtual de Aprendizagem (AVA), disponíveis aos alunos matriculados, mas, como atividades não formais, foram oferecidos diversos cursos e debates pela Escola Superior de Educação, com o objetivo de auxiliar a comunidade no processo de adaptação à quarentena. Nesse sentido, as autoras empreenderam um curso detalhado da montagem, manejo e informação científica referente aos processos que ocorrem na composteira como sistema.

Este capítulo tem o objetivo de trazer os princípios básicos da ecoalfabetização aplicadas ao ensino de geociências, utilizando a montagem da composteira e seu manejo como subsídios à alfabetização ecológica. Para isso, serão apresentadas as bases da ecoalfabetização e sua relação com o ensino de geociências, os princípios da ecoalfabetização aplicados à composteira como sistema e a representação e impactos da ecoalfabetização na comunidade universitária.

\section{PRESSUPOSTOS PARA UMA ECOALFABETIZAÇÃO NO ENSINO DE GEOCIÊNCIAS}

À medida que o ser humano avança rumo a seu objetivo proclamado de conquistar a natureza, ele vem escrevendo uma deprimente lista de destruições, dirigida não só contra a Terra em que ele habita como também contra os seres vivos que a compartilham com ele. [...]. (Rachel Carson, "Primavera Silenciosa", 1962) 
A problemática levantada pela bióloga americana Rachel Carson na década de 1960, em seu livro Primavera silenciosa, trata de uma denúncia a respeito do uso de pesticidas no cultivo agrícola, como o diclorodifeniltricloroetano (DDT), que traziam impactos negativos à fauna e à vida humana e auxiliou na divulgação acerca da exploração agrícola no ambiente. Não fosse pela data de publicação dessa epígrafe, uma citação similar poderia ser inserida para abertura deste texto, pois a humanidade ainda se encontra diante de um contexto parecido e que envolve o aprofundamento dos conflitos entre sociedade e ambiente ou socioambientais.

Acerca da história ambiental e dos pressupostos para o que se entende por "ecoalfabetização" ou "alfabetização ecológica", conforme proposto pelo físico austríaco Fritjof Capra (2006) em seu texto sobre a linguagem da natureza na obra Alfabetização ecológica (BARLOW, STONE, 2006), pode-se considerar que essa vertente da educação ambiental ou, ainda, postura ética está calcada num conjunto de acontecimentos planetários e teorias organizadas a partir da década de 1960, que contribuíram para a virada ecológica na sociedade e nas ciências.

Nesse sentido, a obra "Primavera Silenciosa" de Rachel Carson publicada originalmente em 1962 (CARSON, 2010) foi um marco para as discussões sobre o meio ambiente, as quais tomaram força na década de 1970, sendo a Conferência das Nações Unidas para o Meio Ambiente, em Estocolmo (1972), e a publicação da Hipótese de Gaia (1972, 1979), de James Lovelook e Lynn Margulis, importantes veículos para impulsionar o pensamento ecológico na sociedade e trazer a público os impactos ambientais e suas consequências. Junto a esse cenário, cresce nas ciências a concepção sistêmica de natureza, em que são criados modelos para investigação dos padrões da natureza, corroborando o contexto da virada ecológica, em que, sobretudo, era aclamada uma visão humanitária da natureza. 
No tocante às geociências ${ }^{21}$, nesse mesmo período a perspectiva sistêmica passou a ser adotada massivamente; várias teorias científicas apontavam para a adoção de conceitos como ecossistema ${ }^{22}$ e geossistema ${ }^{23}$ para alcançar uma leitura da natureza que considerasse a interação dinâmica entre os componentes da natureza e suas interações com a sociedade.

A perspectiva sistêmica nas ciências naturais antecede as décadas de 1960 e 1970 e tem suas origens na institucionalização das disciplinas científicas do século XIX. A visão naturalista nas geociências (compatível com a perspectiva sistêmica) pode ser notada nas obras do geógrafo prussiano Alexander von Humboldt (1769-1859), considerado "pai da geografia"; de seu contemporâneo, também prussiano, o biólogo Ernest Haeckel (1834-1919), considerado "pai da ecologia"; e do geógrafo russo Vasily Dokuchaev (1846-1903), considerado "pai da pedologia". Assim, considera-se que as geociências ofereceram um grande aporte de conhecimento para embasar as discussões ambientais, pois os impactos da ação humana na natureza estiveram no foco das investigações dessas ciências desde sua fundação.

A divulgação dos impactos da atividade antrópica na natureza em nível planetário e a necessidade de uma mudança de postura na forma de produzir conhecimento científico, bem como de rever as relações de produção e consumo na sociedade capitalista e reorganização de políticas para uma sociedade mais ecologicamente equilibrada, se desenvolveram nas décadas seguintes e ampliaram suas formas de ação, sendo a educação ambiental fruto da virada ecológica, ganhando destaque nos anos 1990, e a ecoalfabetização uma

\footnotetext{
${ }^{21}$ Em linhas gerais, considera-se geociências o conjunto de ciências que possuem como objeto de estudo a Terra e seus componentes: atmosfera, biosfera, criosfera, litosfera, pedosfera e hidrosfera.

22 Ecossistema é um conceito da ecologia que foi proposto pelo biólogo Arthur George Tansley em 1930, sendo considerado uma "unidade funcional básica na ecologia, pois inclui tanto os organismos quanto o ambiente abiótico" (ODUM, 1988, p. 9).

${ }^{23}$ Geossistema é um conceito da geografia proposto pela primeira vez pelo geógrafo soviético Victor Sotchava, cuja concepção é que "o meio natural organiza-se em termos de hierarquias funcionais - os geossistemas. [...] divide-se em partes (geossistemas de classes diversas e subsistemas) entre os quais estabelece relações simultâneas" (SOTCHAVA, 1978, p.4).
} 
proposta de sistematização de conceitos científicos que auxiliam na leitura da natureza.

Uma leitura sistêmica advinda da ecoalfabetização considera a natureza um todo conectado, um conjunto cuja complexidade é maior que as somas de suas partes. ${ }^{24}$ Retomando Fritjof Capra, para embasar sua perspectiva de alfabetização ecológica nos anos 2000 , podem ser consideradas suas teorias e reflexões publicadas em $O$ ponto de mutação (1982), cuja discussão central se dá entre a perspectiva cartesiana e sistêmica de mundo, e em $A$ teia da vida (1996), trazendo as bases para compreender a ecologia profunda, sendo esta uma perspectiva da ecologia que considera todos os aspectos da vida em integração com a própria manifestação do "ser" no mundo. Derivada de uma postura ética ligada à ecoalfabetização, entende que o domínio dos conceitos sobre natureza e a compreensão de seus processos por parte dos cidadãos são fatores preponderantes para o desenvolvimento de uma sociedade ecologicamente equilibrada. Tal leitura da natureza pode ser viabilizada pelo ensino de geociências em diversos aspectos, conforme apresentado a seguir.

\section{LINGUAGEM, REPRESENTAÇÃO E MODELOS NO ENSINO DE GEOCIÊNCIAS: COMPOSTEIRA COMO SUPORTE}

Uma das questões centrais da ciência encontra-se na linguagem científica e suas representações. Para que se possa oferecer um processo de alfabetização em qualquer ramo do conhecimento científico, é necessário lembrar que as ciências possuem recortes disciplinares que estão em consonância com seus conceitos, teorias e práticas. A exemplo das geociências, sua linguagem diz respeito aos compartimentos e processos da natureza que se tornam inteligíveis ao ser representados.

\footnotetext{
${ }^{24}$ Faz referência aos enunciados da teoria geral dos sistemas, proposta pelo biólogo austríaco Karl Ludwig von Bertalanffy (1901-1972) em 1930. Em sua teoria, ele menciona que o sistema é um conjunto integrado cujo todo é maior que a soma de suas partes.
} 
Os métodos desenvolvidos e aplicados pelas ciências são derivados de condições estratégicas de pensamento colocadas pelos pesquisadores. Parte-se de uma lógica derivada do método, o qual é testado e validado ou não pela comunidade científica, por meio da linguagem científica. Dessa forma, as geociências se articulam em disciplinas com seu próprio conjunto de conceitos, teorias e métodos, se reproduzindo em uma linguagem, pois expressa sua visão por meio de um sistema simbólico (GRANGER, 1994).

Nesse quesito, podemos elencar a ecologia e a biogeografia como duas disciplinas das geociências que auxiliam na organização de conceitos para compreensão da natureza numa perspectiva sistêmica. Pautado nos pressupostos dessas disciplinas, na oficina da composteira, apresentaram-se as bases para uma compreensão da vida por meio de uma óptica não linear, que busca observar os padrões e fluxos de matéria e energia pertencentes ao ecossistema e ao geossistema.

Como suporte para a representação de um sistema, foram discutidos (com foco em um sistema passível de ser utilizado em espaços menores e apartamentos) diversos modelos de compartimentos para a montagem e acompanhamento dos processos biológicos e consequente transformação da matéria. Na Figura 6.1, temos imagens apresentadas na oficina utilizando três baldes plásticos de $15 \mathrm{~kg}$ reaproveitados, sendo 1 e 2 os compartimentos digestores e 3 o compartimento para coleta de chorume ou biofertilizante. 
Figura 6.1 - Compartimentos

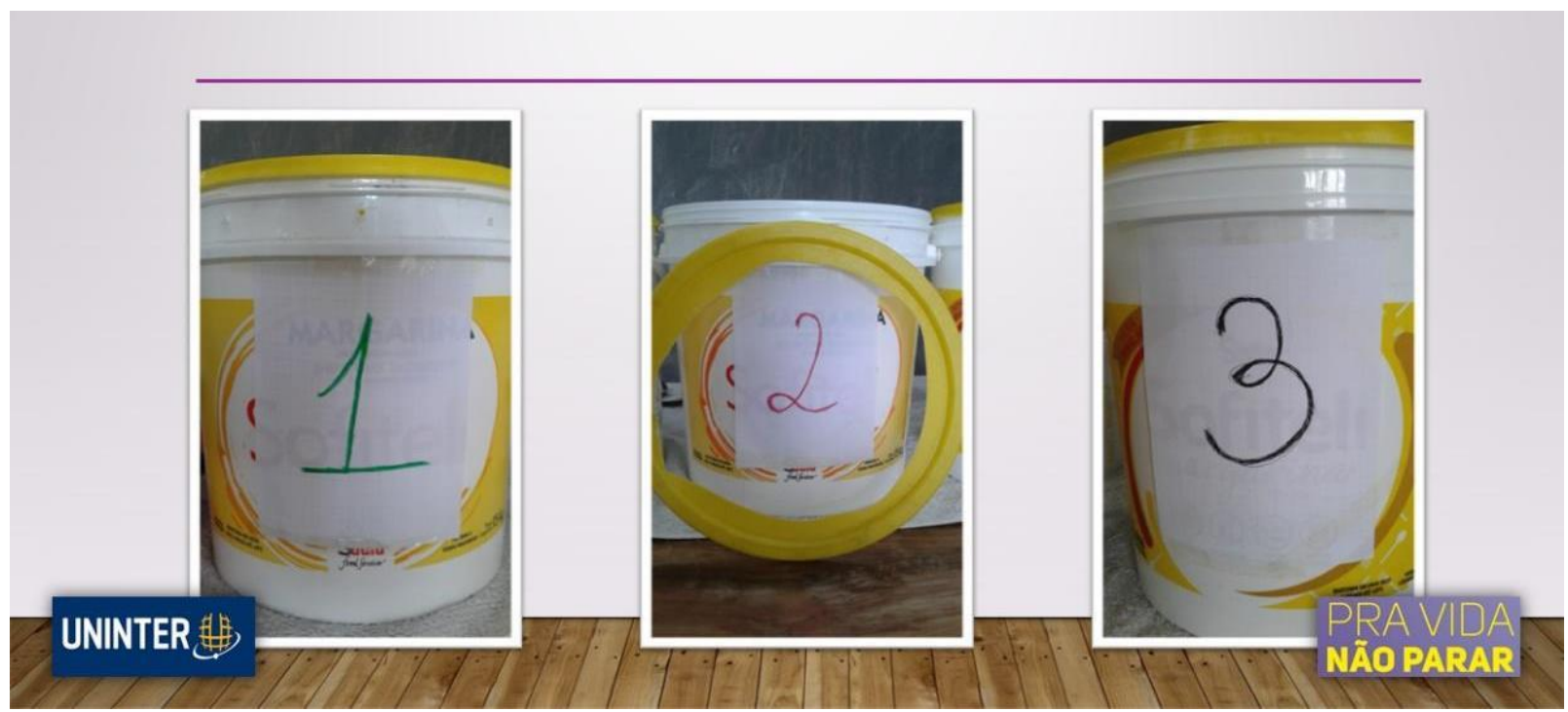

Fonte: as autoras, 2021.

Além dos compartimentos, durante as duas primeiras lives da oficina, foram apresentados os materiais indicados e não indicados para serem introduzidos na composteira, além de alguns tipos de compostagem (compostagem direta, vermicompostagem e compostagem seca). A Figura 6.2 representa uma secção transversal da composteira, podendo-se observar os materiais necessários, suas disposições e, numeradas de 1 a 3, as diferentes etapas do processo de compostagem. Nesse modelo, as laterais dos baldes 1 e 2 possuem pequenos furos para garantir a oxigenação do sistema, permitindo a troca de matéria e energia com o meio externo. Os orifícios devem ser pequenos, entre $3 \mathrm{~mm}$ e $5 \mathrm{~mm}$, e podem ser feitos com pregos ou furadeira. 
Figura 6.2 - Composteira - materiais e etapas

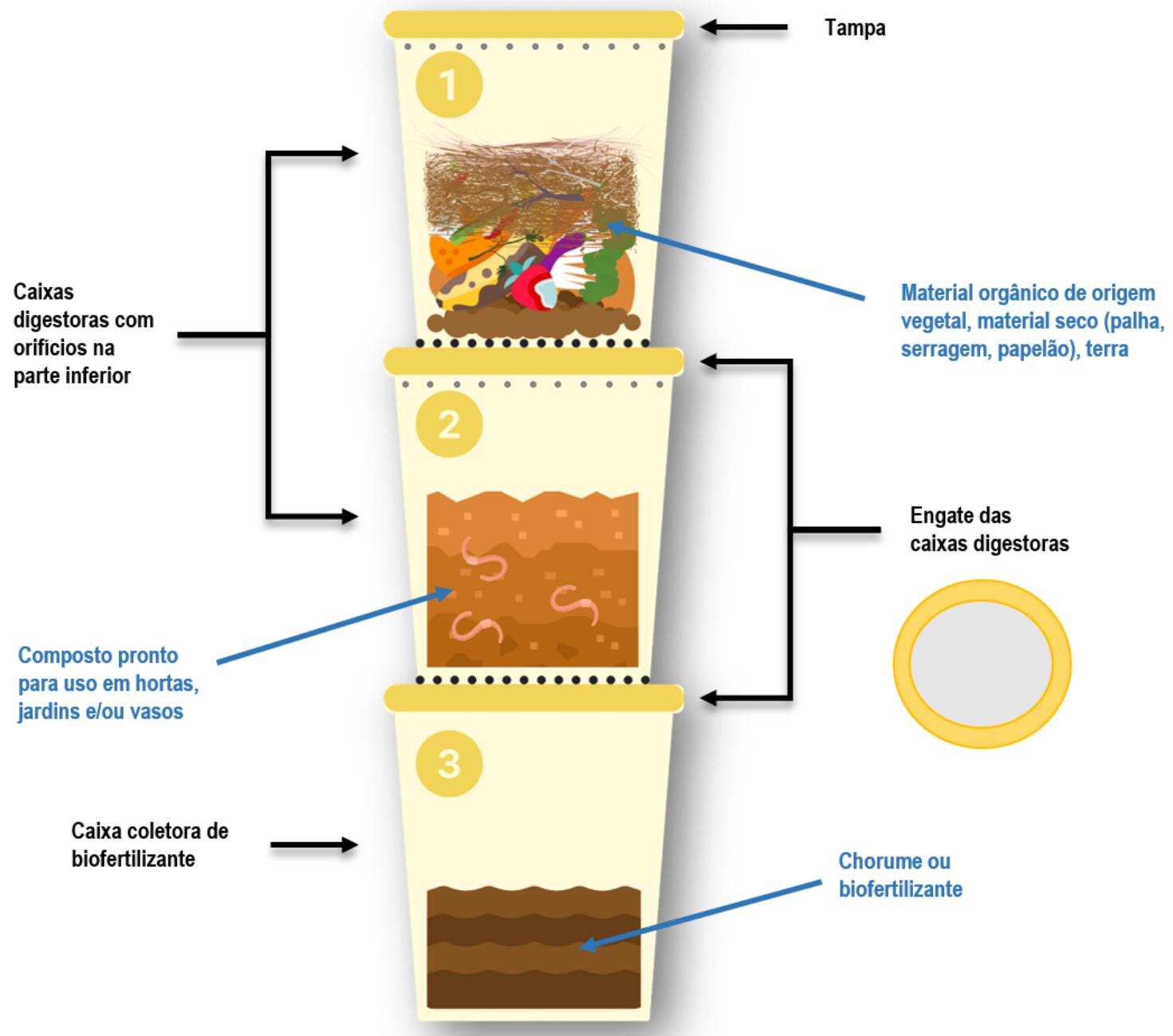

Fonte: as autoras, 2021.

A representação da composteira permitiram que os conceitos fossem trabalhados de forma a ressaltar os processos que envolvem a transformação do material orgânico em insumo para adubagem. Na fase inicial de montagem, alguns conceitos básicos da ecologia foram mencionados, como as trocas de calor, umidade, luz, propriedades físico-químicas da matéria e outros conceitos que serão apresentados adiante. 


\section{PRINCÍPIOS DA ECOALABETIZAÇÃO: COMPOSTEIRA COMO SISTEMA E REPRESENTAÇÃO}

Conforme discutido, a composteira serviu como suporte para representação de processos sistêmicos da natureza. Por esse motivo, diversos conteúdos das ciências da natureza ao longo das lives foram relacionados aos processos biogeoquímicos que ocorrem no processo de compostagem.

A composteira, como modelo e sistema de representação para a compreensão dos princípios da ecologia, permitiu o diálogo sobre conceitoschave da ecoalfabetização, como os anunciados por Capra (2006): sistemas aninhados, redes, interdependência, diversidade, ciclos e fluxos, desenvolvimento e equilíbrio dinâmico. Nesta seção, serão apresentados esses conceitos e como eles foram articulados na oficina de compostagem.

\section{SISTEMAS ANINHADOS}

Ao pensar o uso da composteira dentro de um sistema maior, cabe a reflexão sobre a redução da geração de detritos que comporiam os depósitos irregulares, os lixões a céu aberto e os aterros (controlados e sanitários), locais que, além de demandarem combustíveis fósseis para o transporte dos resíduos, podem contribuir com a poluição dos solos e da água, ser fontes de proliferação de microrganismos patogênicos e, devido à decomposição anaeróbica da matéria, ainda emitir gás metano. Nesses espaços, compreendidos como parte do sistema econômico humano, em contraponto a um sistema ecológico e ao próprio sistema da composteira, a energia se dissipa e os detritos não são vistos como alimentos de outros organismos, ilustrando, eles mesmos, uma lógica linear de entradas e saídas contínuas de inputs e outputs, respectivamente.

Ao mesmo tempo, percebe-se que, "[...] longe de serem entidades distintas, o ambiente natural e a economia humana estão intrinsecamente interrelacionados em específico no que diz respeito aos inputs e aos outputs do processo de produção e consumo" (HUTCHISON, 2000, p. 29), tanto porque da 
natureza retira-se a matéria-prima (inputs) quanto porque é no ambiente natural que ainda, a considerar um sistema de óptica linear, os resíduos (outputs), compreendidos como lixo e, portanto, destituídos de utilidade, são depositados (Figura 6.3).

Figura 6.3 - Sistema de produção (econômico/humano) linear

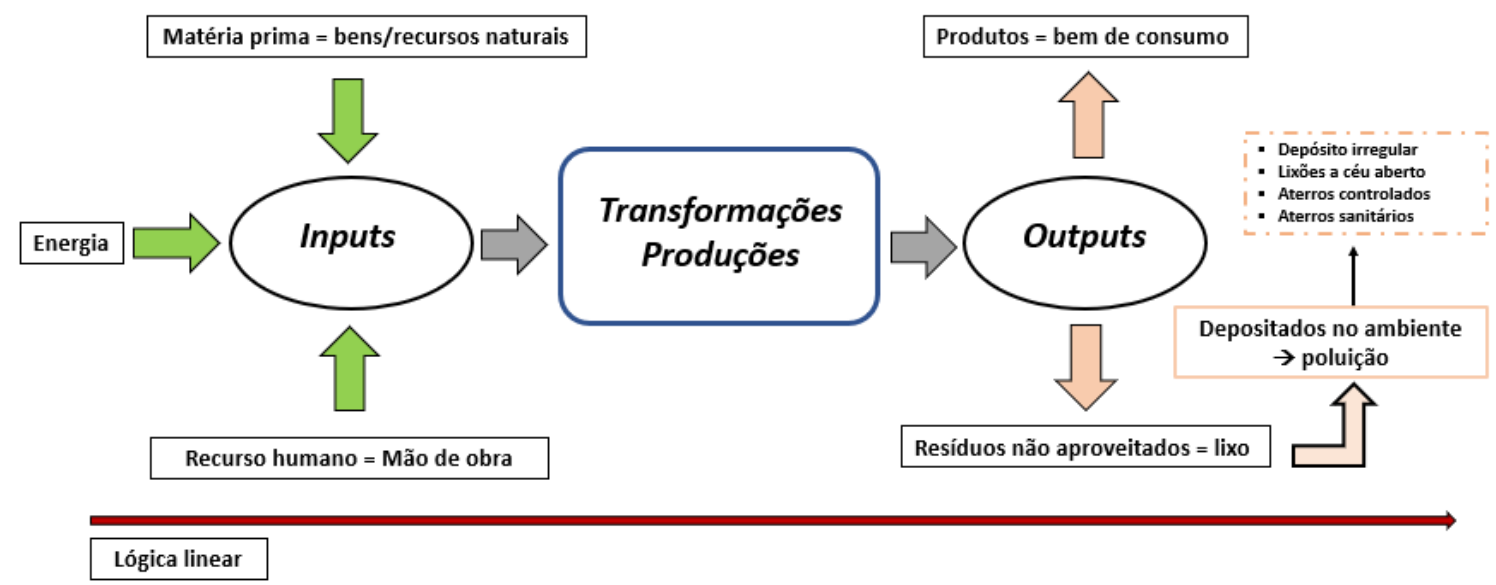

Fonte: as autoras, 2021.

Em contraponto, nos ecossistemas e na própria composteira, a qual reproduz os processos e a dinâmica de um espaço natural, os sistemas são circulares, ou seja, os resíduos da atividade de alguns organismos são recursos para outros, o que resulta na mínima dissipação de matéria e energia (Figura 6.4). 
Figura 6.4 - Representação dos inputs e outputs do sistema da composteira

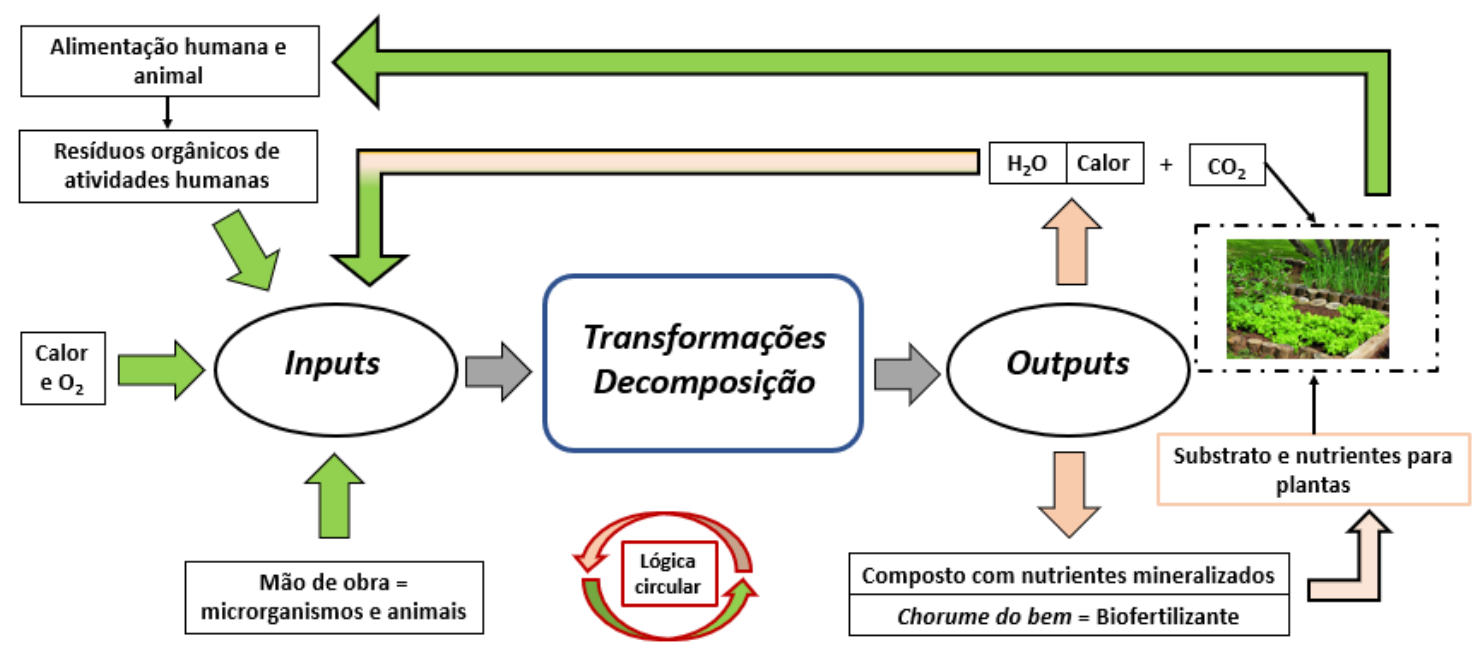

Fonte: as autoras, 2021.

Adicionalmente, quando se fala em sistemas aninhados, pensa-se nas escalas da natureza, nas quais há sistemas dentro de sistemas. Como exemplo, as células, unidades de um sistema vivo, formam um tecido, que por sua vez compõe um órgão e este, um organismo que faz parte de uma população, de uma comunidade, de um ecossistema, de um bioma e, por fim, da biosfera. No entanto, "o que acontece em um nível do sistema afeta a sustentabilidade dos sistemas aninhados nos outros níveis" (CAPRA, 2006, p. 52).

Uma composteira, sendo compreendida como um sistema vivo aberto, quando em leiras e diretamente no solo, ou semifechado, como a representada na Figura 6.2, que está aninhada dentro de uma residência ou uma escola, que por si só são um sistema, interage de forma direta com os sujeitos do processo, pois estes são responsáveis por parte da alimentação do sistema (inputs). É por meio dessa interação que a composteira pode ser um potencial agente transformador do sistema de alimentação dos moradores da casa ou da escola, impactando de forma positiva primeiramente na saúde individual, pela escolha de alimentos vegetais que gerarão detritos para a alimentação dos microrganismos e potenciais animais (micro e mesofauna, como larvas de insetos, nematoides e minhocas, por exemplo), e em um segundo momento 
culminando na redução de resíduos orgânicos eliminados para a coleta de empresas ou da prefeitura, passando do trabalho em nível individual para o trabalho em nível municipal e de lá para níveis ainda mais elevados, dos quais o munícipio faz parte.

\section{REDE}

Segundo Capra (2006), uma vez que os membros de uma comunidade ecológica extraem as suas propriedades essenciais das suas relações, a sustentabilidade não pode ser encarada como uma característica individual, mas, sim, de toda a rede. Ao trazer esse conceito para o trabalho com a composteira, percebe-se que, para que o sistema funcione, é necessário que todos os envolvidos (partes), ou seja, os microrganismos, como as bactérias, os fungos e protozoários, eventuais animais e o próprio humano, que irá alimentar e manter o sistema, estejam em consonância. Portanto, é fundamental que cada parte contribua com o projeto todo, de forma que o efeito de uma amplie o trabalho da outra, objetivando chegar ao ponto de que as partes se retroalimentem e superem a ausência umas das outras. Nesse sentido, o estudante será capaz de compreender essas relações quando, ao construir e manter a sua própria composteira, identificar o seu papel como parte do processo e que suas ações, como quanto aos tipos de alimento adicionados, a periodicidade, o tamanho dos fragmentos, a aeração, entre outras, irão interferir no funcionamento do todo.

O trabalho com o próprio sistema do solo, compreendendo-o como um sistema vivo, é um potencial assunto para a discussão da ideia de rede: para que um solo seja capaz de manter a vida em equilíbrio, todas as suas partes, entendidas como constituintes, precisam estar presentes em quantidade e qualidade ideais. A ausência ou precariedade de uma das partes altera o equilíbrio de todo o sistema, como, por exemplo, a falta de oxigênio resulta na morte dos organismos aeróbios, muitos dos quais decompõem a matéria 
orgânica que viria a constituir o húmus, que, além de fornecer macro e micronutrientes para as plantas, ajuda na estabilização da estrutura do solo.

\section{INTERDEPENDÊNCIA}

Outro princípio ecológico, que governa a teia da vida, pressupõe que nenhum organismo pode viver isoladamente, de tal modo que a sustentabilidade de todo o ecossistema é interdependente. Dentro disso, processos estão intrínsecos à manutenção da vida na Terra, como, por exemplo: a relação entre a respiração celular, a fotossíntese e a ciclagem de nutrientes, tanto do ponto de vista das interações bióticas quanto das transformações da matéria e energia; a fotossíntese, como processo biológico que fixa o gás carbônico e a energia luminosa proveniente do Sol em biomassa vegetal e libera oxigênio para o sistema; a respiração, como resultado da degradação de compostos orgânicos, com subsequente liberação de gás carbônico, que junto dos minerais liberados pela decomposição da matéria imposta por bactérias e fungos, é utilizado pelas plantas novamente; todos são processos que regulam toda a biosfera.

Assim, na concepção da ecologia profunda, o reconhecimento da interdependência fundamental de todos os fenômenos, compreendendo que tanto os indivíduos quanto as sociedades estão todos encaixados nos processos cíclicos da natureza e que, ao mesmo tempo, são dependentes, é fundamental para a construção de uma visão sistêmica de mundo (CAPRA, 1996), base para a alfabetização ecológica.

$\mathrm{Na}$ composteira, a interação entre os organismos e os fatores abióticos (detritos, oxigênio etc.) ilustram a interdependência da vida com a vida, pois é na transformação das condições do meio (como o fracionamento das partículas alimentares, decomposição com liberação de resíduos utilizados por outras espécies, calor liberado pela respiração celular das espécies aquecendo o sistema etc. ), pela atividade de cada organismo presente no sistema, que ocorre a sucessão de espécies e a continuidade dos processos. Nesse sentido, faz-se alusão a Lovelock (2000), ao apontar que as condições na Terra são adequadas 
para a vida, porque os diversos tipos de organismo as tornam favoráveis e as mantêm assim através do tempo.

\section{DIVERSIDADE}

Da mesma maneira, a diversidade de espécies que atuam no sistema da composteira, junto à ideia de rede, otimiza a mineralização dos compostos orgânicos em nutrientes assimiláveis pelas plantas. Em consonância, quanto mais diversas forem a microbiota e a microfauna associada, mais resiliente será o sistema. Segundo Hutchison (2000, p.155), "é a diversidade das espécies dentro das comunidades que permite que a vida prospere".

\section{CICLOS E FLUXOS}

Dentro da composteira, um sistema semiaberto controlado até certo ponto pela ação humana, as interações entre as suas partes e o meio garantem o ciclo da matéria e o fluxo de energia. Os alimentos e o ar devem entrar continuamente no sistema (inputs), permitindo a manutenção da vida por meio dos ciclos biogeoquímicos, nos quais os alimentos participam do ciclo do carbono, do nitrogênio, do enxofre, do fósforo e de outros elementos e o oxigênio, com seu poder oxidante, é utilizado pelos organismos aeróbicos durante a quebra dos compostos orgânicos, tendo como outputs o gás carbônico, calor e água, sendo os dois últimos aproveitados para a manutenção do sistema. A água garante a umidade necessária para as atividades biológicas e o calor derivado da reação exergônica da respiração celular permite a homeostase térmica de todos os organismos e consequente sucessão entre as espécies. Nesse conjunto, é importante entender que "um ecossistema não gera detrito. O detrito de uma espécie torna-se a comida de outra" (CAPRA, 2006, p. 54). Entende-se comida como matéria a ser metabolizada para a geração de energia e matéria-prima, mas também como produto de reações químicas necessárias à manutenção dos corpos. 
O sistema da composteira, seja ele aberto, em forma de leiras ou como buracos no solo, ou semiaberto, integra os sistemas humanos aos sistemas naturais, pois favorece que os resíduos gerados por atividades humanas sejam reciclados e retornem aos ecossistemas como inputs de novos processos biológicos (principalmente, crescimento e desenvolvimento dos vegetais).

\section{DESENVOLVIMENTO}

O desenvolvimento, como um artifício inerente a todos os sistemas vivos e um princípio ecológico importante para compreensão da linguagem da vida, também é possível de ser acompanhado durante a transformação da matéria orgânica. Da mesma forma que durante o seu desenvolvimento, um ecossistema passa por uma série de estágios sucessivos - crescimento rápido, mudança e expansão na comunidade pioneira a ciclos ecológicos mais lentos e uma comunidade mais estável. Estando cada um com uma comunidade com as suas próprias características, os processos que ocorrem do início ao fim da formação do composto refletem o desenvolvimento de um "ecossistema".

De maneira geral, o processo de degradação biológica pode ser dividido em duas fases: biodegradação rápida e humificação (Figura 6.5). Na fase de degradação rápida, chamada também bioestabilização, há intensa atividade microbiológica, elevado consumo de oxigênio e rápida transformação da matéria orgânica. Já nos primeiros dias, ocorre uma intensa proliferação de diferentes populações de microrganismos que se sucedem ao longo do tempo, de acordo com as transformações no meio. No início do processo, há um intenso crescimento de organismos mesófilos, que, à medida que atuam sobre a matéria orgânica, promovem uma rápida liberação de calor, com consequente aquecimento do sistema; com isso, a sua população diminui, dando lugar aos organismos termófilos, que passam a ser dominantes. Essa etapa é caracterizada pela intensa atuação de bactérias e fungos que sobrevivem em ambientes com temperaturas mais elevadas, podendo a temperatura do composto chegar beneficamente a $55-60{ }^{\circ} \mathrm{C}$. Durante essa fase, devido às 
elevadas temperaturas, os organismos patogênicos tendem a ser eliminados, resultando na higienização do composto. Acima dessa temperatura, até mesmo os microrganismos decompositores são eliminados, precisando haver um controle da temperatura, mediante aumento da umidade e aeração.

Figura 6.5 - Fases da composteira

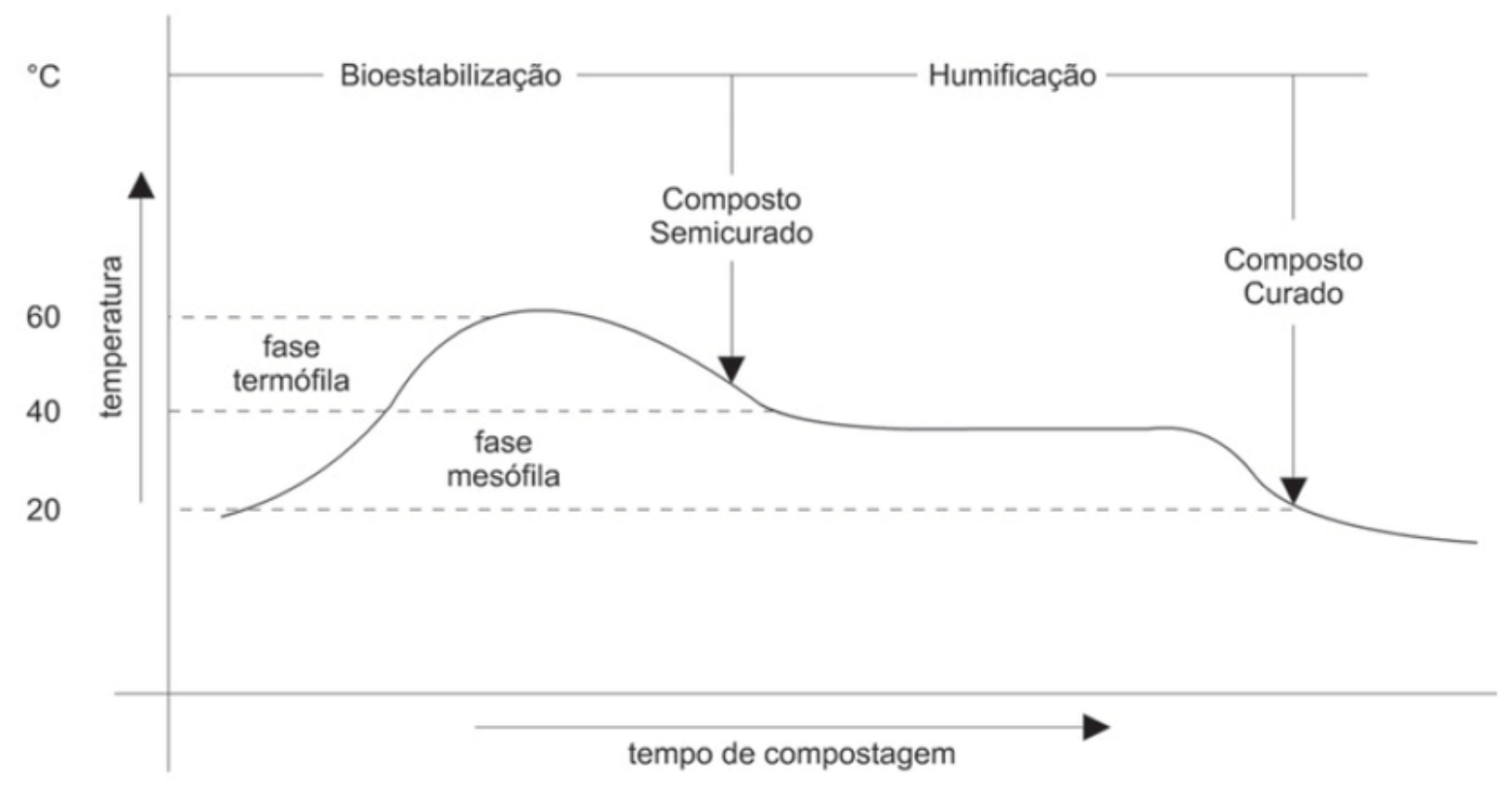

Fonte: D'ALMEIDA; VILHENA, 2000.

À medida que o substrato orgânico é metabolizado, a atividade microbiana decai e, consequentemente, a produção de calor, uma vez que esta é resultado da respiração aeróbica dos microrganismos; assim, o composto adentra na fase de humificação, chamada também maturação, na qual os microrganismos mesófilos se instalam novamente. Como resultado, nessa fase ocorre a mineralização de determinados componentes, com subsequente redução da acidez e temperatura do composto.

Para a completa transformação da matéria orgânica em um produto estável e assimilável pelas plantas, estimam-se entre 90 e 120 dias, a depender de certas condições: umidade (depende dos processos metabólicos dos organismos e dos materiais colocados no sistema, podendo precisar de rega); aeração (a composição das camadas, aberturas realizadas no recipiente e 
revolvimento das pilhas; pouco oxigênio desloca para a decomposição anaeróbica); relação carbono-nitrogênio (importante para o crescimento e atividade metabólica dos microrganismos, portanto, em linhas gerais, é importante balancear a quantidade de material seco - rico em carbono - e fresco - balanço positivo de nitrogênio); os próprios organismos atuantes (quanto mais diversificada forem a micro, meso e macrobiota, mais otimizado estará o processo); temperatura (é importante a variação de calor para a otimização do metabolismo dos microrganismos e sucessão das diferentes comunidades de organismos; frio baixa metabolismo, muito quente elimina os decompositores); e tamanho (partículas muito grandes retardam o processo, enquanto muito pequenas diminuem a aeração).

Além da possibilidade de compreensão da dinâmica dos ecossistemas, quando o projeto que resultou neste artigo foi implementado, ninguém imaginaria os efeitos que poderiam causar naqueles que acompanharam a implementação e a manutenção da composteira. Por exemplo, um participante argentino que reside no município de Córdoba, ao acompanhar a oficina, passou a desenvolver a sua própria composteira e a trocar conhecimentos com seus colegas conterrâneos e com os demais participantes; uma aluna mobilizou a comunidade rural em que vive para terem uma composteira comunitária.

Tais situações corroboram Capra (2006, p. 55), que entende que, "como o desenvolvimento e a co-evolução não são lineares, jamais poderemos predizer ou controlar de que maneira os processos que iniciamos irão se desenvolver. Pequenas alterações podem causar efeitos profundos".

\section{EQUILÍBRIO DINÂMICO}

O último princípio ecológico apontado por Capra diz respeito ao equilíbrio dinâmico, tão importante para a compreensão de que os sistemas biológicos ou mesmo humanos, em qualquer uma das escalas, estão sempre se autorregulando e auto-organizando. Dentro de uma composteira, a atividade dos microrganismos regula o próprio sistema, pois, se há intensa proliferação 
microbiana, há competição por recurso, sendo esta um mecanismo que regula o tamanho das populações. Ao mesmo tempo, se há elevada atividade microbiana, há intenso consumo de oxigênio e liberação de calor, o que aquece o sistema, favorecendo a sobrevivência somente de espécies adaptadas a altas temperaturas (termófilas). Em partes, a manutenção da umidade é governada pelos organismos vivos, que, durante o processo de decomposição, liberam água no estado de vapor e/ou disponibilizam a água presente nos alimentos para o meio; assim, a própria atividade biológica do sistema altera as características ambientais, favorecendo a manutenção da vida.

No entanto, como esse sistema (ao menos o apresentado) foi construído por seres humanos, em parte, o ato do cuidar também favorece a otimização dos processos biológicos, seja ao continuar com o aporte de matéria orgânica (ciclo do carbono, nitrogênio e mineralização dos compostos), seja ao manter a composição adequada das camadas (relação carbono-nitrogênio), a aeração constante mediante revolvimento das camadas e, ao menos, o acompanhamento da umidade e temperatura do sistema.

Quando se apresenta a perspectiva do cuidar da vida, da empatia com todos os organismos vivos, é importante o diálogo com Leonardo Boff, que, na sua obra Saber cuidar: ética do humano - compaixão pela Terra (1999), defende que o planeta Terra, a casa comum, necessita de cuidados, mas para isso é imprescindível que todos sejam ecoalfabetizados, desenvolvendo o que ele denomina "ética do cuidado" e cuidadosamente aderindo aos nove princípios da sustentabilidade, comungados em 1991 e publicados sob o título Caring for the Earth (Cuidando do planeta Terra): (i) construir uma sociedade sustentável; (ii) respeitar e cuidar da comunidade de seres vivos; (iii) melhorar a qualidade da vida humana; (iv) conservar a vitalidade e a diversidade do planeta Terra; (v) permanecer nos limites da capacidade de suporte do planeta Terra; (vi) modificar atitudes e práticas pessoais; (vii) permitir que as comunidades cuidem de seu próprio meio ambiente; (viii) gerar uma estrutura nacional para integrar desenvolvimento e conservação; (ix) construir uma aliança global, princípios 
possíveis de ser abarcados utilizando a composteira como modelo didático e transformador de consciência e ação.

\section{CONSIDERAÇÕES FINAIS}

Neste texto, foram trazidos elementos para alfabetização ecológica a partir da composteira como representação de um sistema semiaberto e que permite a observação de importantes conceitos da ecologia. No momento crucial que a humanidade atravessa, diante da pandemia da Covid-19, é necessária uma ampliação de esforços para que os saberes científicos sejam apropriados pelos cidadãos, como forma de garantir um ambiente ecologicamente equilibrado e maior equidade de conhecimento. Nesse sentido, o conhecimento científico, aliado aos conhecimentos prévios dos sujeitos, possibilita uma maior autonomia e responsabilidade nos diferentes cenários do contexto socioambiental.

Prenunciada na década de 1970, a crise ecológica se expande na horizontal e na vertical, atingindo todas as camadas da sociedade e ecossistemas. Com o apoio da composteira, foi possível conectar e demonstrar uma pequena parcela das inúmeras variáveis existentes nos sistemas vivos; nesse quesito, a complexidade é a tônica da alfabetização ecológica e foi retratada por meio de uma metodologia desenvolvida e pautada nas ciências da natureza.

O sistema da composteira, utilizado como um modelo de representação dos princípios ecológicos prenunciados por Capra (2006), se mostrou eficaz não só para a compreensão de fenômenos e processos biológicos, mas também permitiu o diálogo com conceitos-chave da ecoalfabetização. Assim, dentro do que foi observado, a implantação e manutenção de uma composteira em ambiente domiciliar ou escolar podem ser incorporadas como uma estratégia metodológica importante para o ensino das geociências, em consonância com a busca por formar sujeitos que percebam a interdependência que há entre sociedade e ambiente e permitam encontrar caminhos para a resiliência e ações para a sustentabilidade. 
Como possibilidades de ampliação dessa proposta, cabe a continuidade de atividades com a implantação real e permanente do cultivo de alimentos que utilizem o composto produzido e, depois, se fazendo a colheita, o consumo e a ciclagem dos resíduos novamente no sistema, completando o ciclo. Além da decomposição aeróbica dos resíduos orgânicos, cabe a implantação de biodigestores, como sistemas anaeróbicos que produzem o biogás, uma mistura de dióxido de carbono e gás metano, que pode ser utilizado como um substituto do gás de cozinha. Assim, considera-se que as estratégias pedagógicas utilizando mídias sociais são uma grande ferramenta para mobilização das comunidades com acesso à rede e apontam para a inserção e consolidação de uma rotina doméstica e escolar com base na alfabetização ecológica.

\section{REFERÊNCIAS}

BARLOW, Zenobia; STONE, Michael K. (orgs.) Alfabetização Ecológica: A educação das crianças para um mundo sustentável. São Paulo: Cultrix, 2006.

BOFF, Leonardo. Saber cuidar: Ética do humano - compaixão pela Terra. 16ed. Petrópolis, RJ: Vozes, 1999.

CAPRA, Fritjof. Teia da Vida: uma nova compreensão científica dos sistemas vivos. São Paulo: Cultrix, 1996.

CAPRA, Fritjof. Falando a linguagem da natureza: Princípios da Sustentabilidade. In: BARLOW, Zenobia; STONE, Michael K. (orgs.) Alfabetização Ecológica: A educação das crianças para um mundo sustentável. São Paulo: Cultrix, 2006.

CARSON, Rachel. Primavera Silenciosa. São Paulo: Gaia, 2010.

D'ALMEIDA, M. L. O., VILHENA, A. Lixo municipal: manual de gerenciamento integrado. São Paulo: IPT: CEMPRE, 2000.

GRANGER, Gilles-Gaston. A ciência e as ciências. São Paulo: Editora da UNESP, 1994.

HUTCHISON, David. Educação Ecológica: ideias sobre consciência ambiental. Porto Alegre: Artes Médicas Sul, 2000.

LOVELOCK, James. Gaia: um modelo para a dinâmica planetária e celular. In: THOMPSON, Willian Irwin. (Org.) Gaia: Uma teoria do conhecimento. São Paulo: Editora Gaia, 2000.

MORIN, Edgar. Para onde vai o mundo? Petrópolis: Editora Vozes, 2010.

MORIN, Edgar. Os sete saberes necessários à educação do futuro. Brasília: Cortez Editora, 2011.

ODUM, Ecologia. Rio de Janeiro: Guanabara,1988.

SOCHAVA, V. B. Por uma teoria de classificação de geossistemas da vida terrestre. Biogeografia. n.14. São Paulo: Instituto de Geografia da USP, 1978.

WARNAVIN, Larissa. WITT; Nicole G. P. M. Composteira Doméstica: Como fazer? vídeo. 35m38s. 31 de março de 2020. Disponível em: <https://www.facebook.com/ 476750065760948/videos/669275307224130>. Acesso em: 30 mar. 2021. 


\title{
CAPÍTULO 7 - PRÁTICAS DE ENSINO: A ESCOLA, O PROFESSOR E O ESTUDANTE PÓS- PANDEMIA
}

\author{
"[...] E o aluno não saiu para estudar \\ Pois sabia o professor também não 'tava' lá \\ No dia em que a Terra parou, oh oh oh oh $[\ldots]^{\prime \prime}$ \\ Compositores: Claudio Roberto Andrade De Azeredo / Raul Seixas \\ Excerto da Letra de O Dia Em Que a Terra Parou

\begin{abstract}
MARIA ENEIDA FANTIN 25
VERA CRISTINA SCHELLER DOS SANTOS ROCHA 26 NICOLE GERALDINE DE PAULA MARQUES WITT'27
\end{abstract}

No início do ano letivo de 2020, as aulas foram suspensas nas escolas de educação básica de todo o Brasil em função da pandemia do novo coronavírus. Num instante, o que até então era apenas criação artística do poeta, parecia se

25 Licenciada e bacharela em Geografia pela UFPR (1987). Mestra em Tecnologia pela UTFPR (2003). Graduada em Pedagogia pelo Centro Universitário Internacional Uninter (2017). Professora na Área de Geociências no Centro Universitário Internacional Uninter

26 Licenciada em Geografia pela Universidade Estadual de Londrina. Licenciada em Pedagogia pelo Centro Universitário Internacional Uninter. Pós-graduada em Gerenciamento de Recursos Ambientais pela Universidade Braz Cubas. Graduanda em História no Centro Universitário Internacional Uninter. Tem vasta experiência em sala de aula, tanto no Ensino Médio quanto no Ensino Fundamental II, na rede pública e privada. Atualmente, pertence ao corpo docente da área de Geociências do Centro Universitário Internacional Uninter.

27 Bacharela e licenciada em Ciências Biológicas pela UFPR (2010). Especialista em Educação, Meio Ambiente e Desenvolvimento pela mesma instituição (2012). Especialista em Inovação e Tecnologia na Educação pela UTFPR (2020). Tem experiência na área de botânica, com ênfase em fisiologia vegetal, atuando principalmente na propagação vegetativa de espécies de interesse para a conservação de áreas degradadas e de interesse medicinal. Trabalhou também com peixes e aves marinhas, os quais constituíram a sua pesquisa monográfica. Atualmente, é professora do Ensino Médio do Colégio Nossa Senhora Medianeira e integrante do corpo docente da Área de Geociências (cursos de Licenciatura e Bacharelado em Ciências Biológicas e Geografia) do Centro Universitário Internacional Uninter, compondo o Grupo de Pesquisa Atlas Geociências. Atua também com produção e edição de materiais didáticos para a educação básica e ensino superior. 
tornar realidade. Passado o impacto inicial e percebido que a situação de excepcionalidade poderia durar muito mais tempo do que o imaginado, buscaram-se alternativas para a continuidade das aulas e para que, de alguma forma, as crianças não perdessem o ritmo dos estudos.

$O$ inusitado isolamento social e o fechamento das escolas trouxeram tensões diversas entre todos os sujeitos envolvidos com a educação básica. A urgência do calendário escolar fez com que os órgãos responsáveis pelas escolas, em especial, as Secretarias de Educação responsáveis por grandes redes de escolas públicas, vinculassem estudantes e professores a um sistema de aulas ao vivo e gravadas, de registros de presenças, de entrega de tarefas e notas, entre outras atividades.

O primeiro impacto, então, sobre a educação básica foi a quebra da tradição do ensino presencial e a dura realidade da falta de acesso à internet e de computadores dificultou a inclusão de muitos alunos e até professores nesse contexto. Além de ter de vivenciar o ensino e aprendizagem por meio de recursos tecnológicos sem os equipamentos necessários, veio à tona a grande lacuna da formação inicial dos professores, que não são preparados para uso da tecnologia em favor da educação. Assim, o corpo docente sofreu muito enfrentando a falta de preparo, a falta de habilidade para os novos procedimentos e, principalmente, a falta de possibilidade de reflexão coletiva e sistematizada sobre a nova realidade pedagógica. Esse sofrimento repercutiu de forma dramática na sociedade, desencadeando um sem-número de problemas, críticas e desconfortos por parte também das famílias e dos estudantes.

Para os professores que sempre estiveram em sala de aula e, de uma hora para outra, viram-se tendo de ensinar por meio remoto, o impacto foi grande. A pouca lida cotidiana com os recursos tecnológicos e as inconsistências do funcionamento do sistema geraram muito estresse, o que resultou numa reação negativa imediata ao que se denominou, equivocadamente, naquele momento, educação a distância. De outro lado, a sociedade ficou também insatisfeita com a descontinuidade da rotina de ensino, a falta de organicidade dos conteúdos escolares disponibilizados via remota e até alguns exageros propostos como 
tarefas e compromissos estudantis às crianças. Tudo isso também levou a críticas ao ensino a distância.

Mas, afinal, o que começou a se configurar naquele momento pode ser chamado educação a distância? A modalidade a distância é tão somente a transposição das aulas presenciais para plataformas de comunicação a distância? De acordo com Santana e Salles (2020), ela está presente na legislação educacional desde o art. 80 da Lei de Diretrizes e Bases (LDB) ao Decreto no 9.057/2017. O ensino híbrido, por sua vez,

[...] é outro conceito que tem um marco conceitual avançado, com significativa construção teórica desenvolvida recentemente. [...] Em uma vasta revisão de literatura realizada em seis fontes referenciadas no cenário científico-acadêmico: nas publicações ocorridas no período de 2015 a 2019, Anjos e outros autores (2019), encontraram um total de 523 artigos, que após o refinamento da pesquisa com critérios de inclusão e exclusão, alcançou 155 trabalhos. Esses números revelam um campo teórico já significativo sobre o conceito de Ensino Híbrido, suas práticas e fundamentos (SANTANA; SALES, 2020, p. 79).

Contudo, as formas alternativas para dar continuidade ao ensino e aprendizagem escolar que emergiram no contexto da pandemia, ainda que usem ferramentas tecnológicas também aplicadas em cursos no formato de educação a distância, estão longe de se configurar como tal.

[...] em razão sobretudo da pandemia de COVID-19, uma outra terminologia ganha repercussão e visibilidade: o ensino remoto. A legislação vigente, mesmo a construída em razão da pandemia de COVID19 , não contempla conceitualmente nem procedimentalmente o ensino remoto como tipologia ou modalidade de ensino. No entanto, o termo se popularizou na mídia, nas redes sociais digitais e entre gestores públicos na tentativa de nomear as ações pedagógicas criadas para atender às regulamentações emergenciais emitidas pelos órgãos públicos no que se refere a educação escolar em tempos de pandemia (SANTANA; SALES, 2020, p. 81).

Montar às pressas um sistema de vinculação de alunos e professores a uma plataforma digital e gravar algumas aulas expositivas e enviar tarefas a ser realizadas pelos estudantes e corrigidas pelos professores não configuram uma proposta consistente de educação a distância, mas apenas um recurso 
emergencial, para um momento de exceção, como já foi dito. O que se ofereceu ao longo de 2020 aos estudantes da educação básica em termos de ensino remoto não teve um projeto pedagógico refletido e definido coletivamente, tampouco um preparo prévio, afinal a pandemia pegou a humanidade de surpresa.

\begin{abstract}
Embora a legislação não conceitue o ensino remoto nem o adote como categoria fundamentada em referenciais teóricos consolidados [...] Santo e Trindade (2020) demarcam o surgimento do ensino remoto emergencial (ERE) a partir de situações atípicas como pandemias e outras catástrofes [...]. A inclusão dos termos emergencial e do remoto na definição das práticas de ensino desenvolvidas no contexto que o mundo está vivendo em 2020 é fundamental na perspectiva de Tomazinho (2020), pois o que caracteriza o remoto é a impossibilidade de professores e estudantes frequentarem as escolas em razão da tentativa de contenção da propagação do novo coronavírus. Já o emergencial, situa a temporalidade desta alternativa, uma vez que os planejamentos pedagógicos de todas as instituições de ensino foram interrompidos abruptamente, com riscos de não mais serem aproveitados no ano de 2020 e novas alternativas precisaram ser adotadas na mesma velocidade (SANTANA; SALES, 2020, p. 81-82).
\end{abstract}

No balanço das perdas e ganhos, apesar de todos os esforços para manter a continuidade do calendário escolar, a interação com os alunos nas aulas remotas foi muito baixa e, mesmo quando ocorreu, nem sempre se dava com as turmas reunidas. As explicações para esse dado são diversas, destacando-se as dificuldades de acesso à internet ${ }^{28}$ para uma parcela significativa de famílias, a falta de supervisão familiar sobre a frequência dos estudantes nas aulas remotas, a sensação de não ter compromisso com os estudos por não ir à escola, entre outras.

Para os professores, as novas atribuições implicaram, também, uma nova didática, mais rígida, com menor possibilidade para as interações imprevistas e para a participação inesperada e surpreendente do estudante, o que anima e dá vida às relações pedagógicas na escola. Assim, de repente, os docentes se viram diante da necessidade de ministrar aulas formais, na frente de uma câmera,

28 De acordo com o Comitê Gestor da Internet no Brasil, 39\% dos domicílios brasileiros não têm acesso à internet por falta de computador (dados de 2018). 
atentos à iluminação, sons externos, velocidade de internet e tantos outros aspectos com os quais jamais precisaram se preocupar durante o fazer docente.

Nesse novo formato de ensino, o professor da educação básica precisou redimensionar o uso do tempo da aula, contar menos com a participação dos estudantes, com a contraposição de ideias que pode levar a uma nova abordagem do tema. Teve, então, de buscar outras formas - também dinâmicas - tanto para ensinar quanto para a sistematização do conhecimento abordado, que geralmente se faz na conclusão de cada aula.

$\mathrm{Na}$ educação remota predomina uma adaptação temporária das metodologias utilizadas no regime presencial, com as aulas, sendo realizadas nos mesmos horários e com os professores responsáveis pelas disciplinas dos cursos presenciais, como dito anteriormente. Esses professores estão tendo que customizar os materiais para realização das atividades, criando slides, vídeos, entre outros recursos para ajudar os alunos na compreensão e participação das atividades. Contudo, nem sempre a qualidade destes materiais atende aos objetivos desejados (ALVES, 2020, p. 358).

O padrão de comportamento dos sujeitos da relação ensinoaprendizagem, plenamente dominado pelo professor nas aulas presenciais, não é o mesmo nas aulas remotas. Como, nesse formato, a dinâmica é diferente, o papel do professor tornou-se, num primeiro momento, mais burocrático e menos didático. Houve crise de identidade, mais angústia e descontentamento entre os docentes. Da perspectiva dos estudantes, o que se pôde observar no ano letivo de 2020 foi que alguns procuraram fazer as tarefas propostas pelos professores, postando trabalhos e exercícios nas plataformas indicadas, realizando as atividades avaliativas de acordo com as orientações. Contudo, mesmo entre os mais aplicados prevaleceu a percepção de que a aprendizagem foi menor do que antes, quando iam para a escola e tinham aulas presenciais.

A literatura baseada em evidências mostra que alunos que têm atividades totalmente a distância aprendem menos do que aqueles com a vivência presencial nas escolas, mesmo levando em conta outros fatores que poderiam afetar o desempenho acadêmico. $E$, mesmo quando o ensino não é totalmente a distância, as evidências ainda são mistas quanto aos efeitos das tecnologias educacionais na aprendizagem dos alunos, além 
de apontarem que muitas tendem a ser pouco custo-efetivas (BRASIL, 2020, p. 6).

Por sua vez, as famílias também tiveram de enfrentar dificuldades e viramse diante de responsabilidades antes delegadas à escola. Nos lares mais comprometidos e engajados, os estudantes tiveram familiares que acompanharam os horários de aulas, corrigiram as atitudes inadequadas, observaram o esforço dos estudantes, verificaram tarefas, ajudaram nas explicações dos conteúdos, enfim, gastaram muito mais tempo e energia com os estudos das crianças do que faziam antes da pandemia.

Diante de todas essas questões, volta-se à pergunta inicial para reafirmar que as aulas remotas, sem projeto pedagógico claro e coletivamente definido, não se configuram como educação a distância. A modalidade a distância é outra coisa e o debate sobre ela ultrapassa os objetivos deste texto, além de ser complexo e profundo. O debate sobre uma educação básica nessa modalidade não está posto de forma clara e consistente para a sociedade e, caso venha a acontecer, deverá envolver todos os sujeitos da educação. Na educação básica, por mais que se estimule o uso das tecnologias aplicadas ao processo de ensino e aprendizagem, não se trata de supor que, automaticamente, a educação a distância seja adequada para crianças e jovens.

Dito isso, destaca-se que a travessia imposta pela pandemia do novo coronavírus trouxe reflexões sobre a relevância da escola como instituição social, seu papel como lugar de ensino e aprendizagem, de socialização do saber, mas também de cuidado, de acolhimento e proteção da infância e da juventude. 0 papel social, político e cultural desempenhado pela escola na formação e desenvolvimento físico, emocional e intelectual dos estudantes da educação básica é fundamental e continua validado pela sociedade, que quer a volta às aulas presenciais o mais brevemente possível; espera-se, assim, que se tenha controle sobre a Covid-19, com medicamentos e vacina.

Contudo, uma nova pergunta se apresenta: como será a escola depois da pandemia? Será que a vivência imposta pelo atual contexto e todo o aprendizado 
dela decorrente não afetarão em nada a futura educação presencial? Como será o comportamento do professor, do estudante e da família depois que tudo isso passar?

A sociedade teve expostas contradições e desigualdades já sabidas, que influenciam os resultados da função social da escola, e terá de decidir se quer enfrentá-las e superá-las. Todos os sujeitos envolvidos na educação perceberam limites e possibilidades que podem alterar o ensino num futuro próximo, afinal:

a) Os professores conheceram recursos didáticos tecnológicos que podem continuar utilizando nas aulas presenciais, de modo que se tornem mais lúdicas, mais interativas, interessantes e envolventes.

b) Os estudantes, embora tidos como nativos digitais, perceberam que não dominavam nem conheciam todos os recursos tecnológicos a eles propostos e sugeridos e que não basta utilizar as redes para diversão e entretenimento, mas é preciso saber usá-las para estudar, para agregar conhecimento sistematizado.

c) As escolas tiveram (e terão) de lidar com os estudantes não incluídos digitalmente, aqueles que, sem acesso e sem equipamentos, passaram pela pandemia de modo precário no que se refere ao processo educacional.

d) As famílias se depararam com a falta concreta que a escola faz nos seus cotidianos e espera-se que façam autocrítica e percebam o quanto é árduo o trabalho educacional e o quanto são importantes sua participação e contribuição, uma vez que a escola sozinha faz diferença, mas não opera milagres.

e) Os governos e as mantenedoras privadas viram escancarados os problemas que precisam ser enfrentados para uma gestão educacional inclusiva, que honre o princípio constitucional da educação como direito de todos, com acesso, permanência e qualidade.

Nesse momento de reflexão inevitável e em busca de uma nova configuração da escola depois da pandemia, surgem alguns argumentos sobre o ensino híbrido e a defesa da sua implementação na educação básica. Fazendo o 
contraponto, especialistas afirmam que aulas e atividades remotas são absolutamente inadequadas para a Educação Infantil e o Ensino Fundamental, porém flertam com a possibilidade de inserir porcentagens da carga horária do Ensino Médio no formato a distância.

Enfim, se após a pandemia o entusiasmo pelo ensino híbrido aumentar, será preciso intensificar os debates sobre todos os aspectos mencionados anteriormente neste texto. Deverá ocorrer uma ampla discussão na sociedade, buscando redimensionar o papel e as incumbências de governos, família e cada um dos sujeitos da educação. Da perspectiva pedagógica, no que se refere ao fazer diário na escola, será necessário refletir sobre a complexa interação entre professor e aluno por via remota e em tempo real; sobre a importância de atividades teórico-práticas e das aulas ao vivo, com práticas e experiências; sobre as atividades avaliativas diversificadas, possibilitando a expressão escrita e oral e estimulando as diversas habilidades intelectuais do estudante, entre outros aspectos que envolvem o processo de ensino e aprendizagem.

Por isso, nos limites deste texto, propõe-se a partir daqui contribuir com professores de Geografia, Ciências e Biologia, para refletir sobre possibilidades de uso de tecnologias educacionais que configurem uma nova prática pedagógica, numa escola renovada, pós-pandemia.

\section{O ENSINO de CIÊnCIAS E BIOLOgIA NO CONTEXTO DA PANDEMIA DA COVID-19}

Em cenário de pandemia e de modelo remoto emergencial, termo cunhado por Moreira e Schlemmer (2020), uma nova prática docente se fez presente e, com isso, diferentes estratégias e plataformas se tornaram essenciais, desde os meios de comunicação para a interação síncrona com o aluno a aplicativos, softwares, simuladores e jogos, on-line e digitais. Apesar de todas as dificuldades e desafios, a incorporação forçada das tecnologias educacionais no ano de 2020 torna quase obrigatória a utilização desses recursos nos anos que seguem, no formato remoto, híbrido ou presencial. Portanto, com o intuito de 
contribuir com a prática docente nos componentes de Ciências e Biologia, serão descritas algumas atividades que fazem uso das Tecnologias Digitais da Informação e Comunicação (TDICs) e podem ser facilmente aplicadas às três modalidades de ensino

Uma estratégia-coringa, moldável a diferentes conteúdos de Ciências e Biologia, consiste na aplicação do método da sala de aula invertida em conjunto com repositórios virtuais, Ambientes Virtuais de Aprendizagem (AVAs) ou um roteiro prévio com orientações (impresso ou em arquivo digital disponibilizado em plataforma on-line ou mesmo indexado por QR code), somados a um aplicativo de questões, como o Socrative (www.socrative.com).

De maneira simplificada, a proposta consiste em o professor encaminhar antecipadamente ao aluno um material preparado por ele, como um roteiro dirigido contendo o passo a passo da atividade e indicações de materiais de pesquisa (textos, documentário, filme, podcasts, videoaulas etc.) de determinado conteúdo ainda não trabalhado em sala. Em casa, o estudante realiza as pesquisas e completa as atividades propostas de forma a refletir previamente sobre os conteúdos a ser abordados em sala. Adicionalmente, como atividade de verificação do grau de assimilação do conteúdo (individual e coletivo), o professor disponibiliza o nome da sala do Socrative, na qual estão as questões que avaliam a aprendizagem. Ainda antes da aula, o docente avalia o quadro com as respostas dos alunos (Figura 7.1) e, a partir do observado, organiza a aula, identificando as aprendizagens. 
Figura 7.1 - Exemplo de quadro com as respostas assinaladas pelos estudantes ao responder a um questionário no aplicativo Socrative

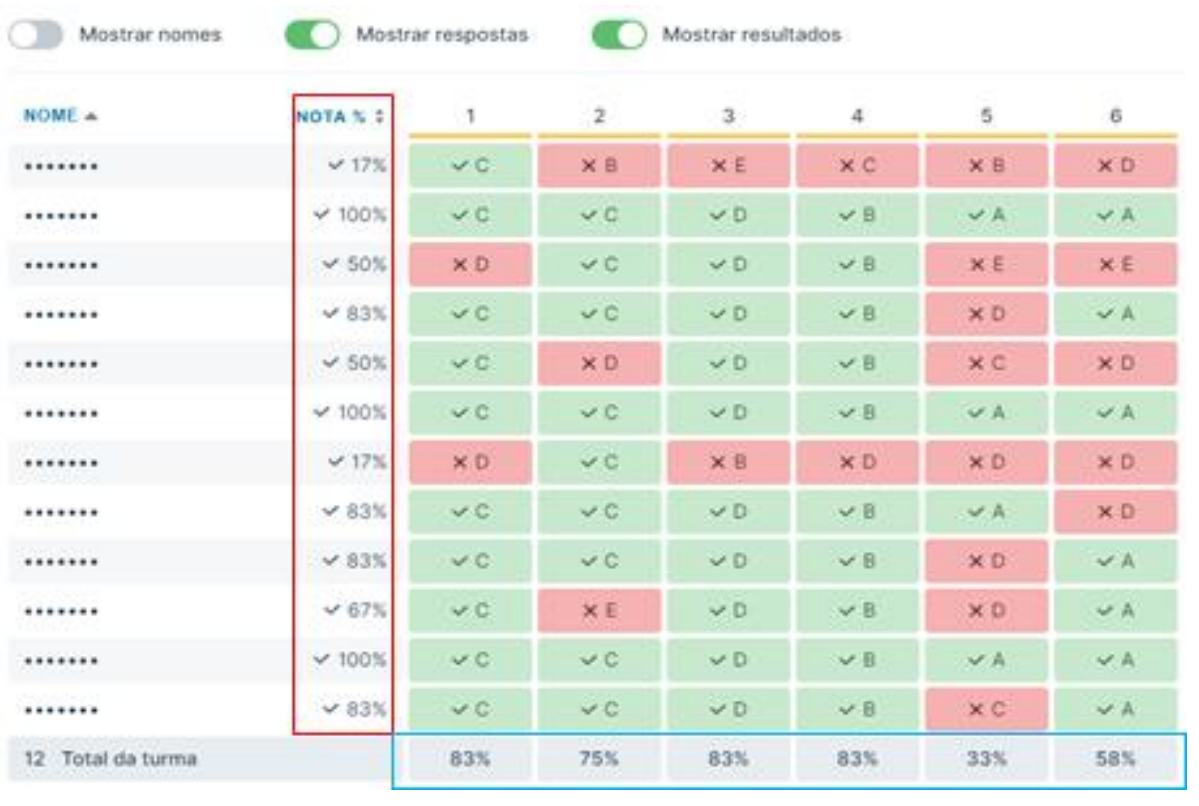

Fonte: as autoras via Socrative (www.socrative.com), 2021.

Nota: Marcadas com o quadro vermelho, as notas individuais e, marcados com azul, os percentuais de acerto de cada questão.

Dependendo de como o questionário é montado, há dois caminhos pedagógicos. O primeiro deles ocorre quando, ao criar o questionário, o professor escolhe o feedback instantâneo; com isso, os alunos obtêm as respostas corretas e explicações (caso o professor as coloque em cada questão) à medida que realizam o questionário, possibilitando a autorreflexão. A segunda opção consiste em deixar o questionário aberto para navegação, deixando a devolutiva para o momento síncrono. Com essa escolha, o professor pode discutir diretamente as respostas ou optar por ofertar o mesmo questionário ao final da aula, comparando as aprendizagens antes e depois do momento da discussão. No entanto, independentemente do caminho escolhido, o encontro entre educador e educando deve permitir ao estudante sanar as suas dúvidas, consolidar e aprofundar os conhecimentos acerca do assunto estudado.

A segunda atividade apresentada neste texto versa sobre a importância e o desafio de manter as aulas práticas em cenário remoto ou de ensino híbrido e até mesmo em escolas que não dispõem de um laboratório de ciências e/ou 
biologia. Atualmente, existem diferentes propostas, principalmente no ensino das Ciências da Natureza e Exatas, sendo ainda mais presentes na Matemática, Física e Química, que trazem simuladores e laboratórios remotos para a sala de aula, contemplando os chamados Objetos de Aprendizagem (OAs), os quais, segundo Aguiar e Flôres (2014), correspondem a qualquer recurso digital que pode ser reutilizado para apoiar a aprendizagem, podendo ser simples como uma animação ou complexos como uma simulação.

Para os simuladores, um exemplo muito interessante é o projeto Physics Educacional Technology (PhET) ${ }^{29}$ (https://phet.colorado.edu/pt_BR) da Universidade do Colorado, que oferece gratuitamente simulações virtuais de fenômenos relativos às Ciências da Natureza e contempla conteúdos de Ciências e Biologia (Figura 7.2). Para as simulações, não é necessário um cadastro e os alunos podem interagir a partir de smartphone, tablet ou computador. O que torna o projeto ainda mais interessante é que, em todas as simulações, há um campo "para professores", que contém um arquivo em PDF que ajuda a explicar a atividade e aponta alguns dos insights sobre o pensamento dos estudantes. Para o docente obter essas informações, basta um cadastro simples.

Figura 7.2 - Simulações disponíveis no PhET para o ensino de Ciências e Biologia

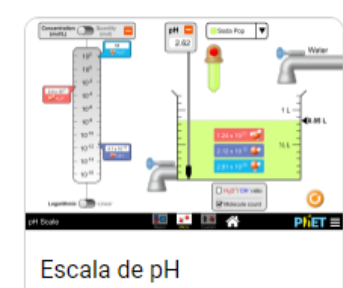

固

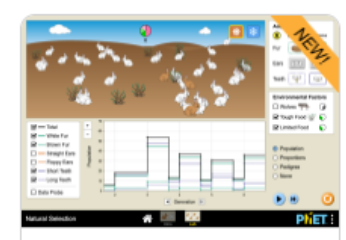

Seleção Natural

国

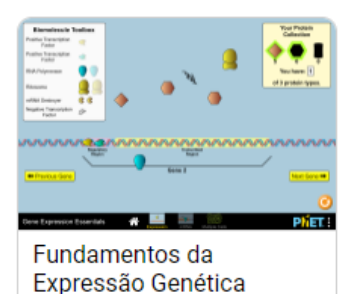

囫

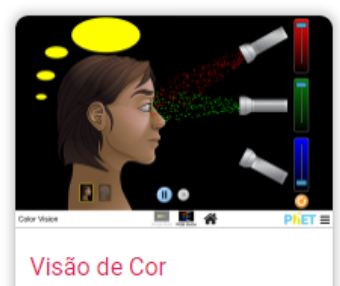

囫

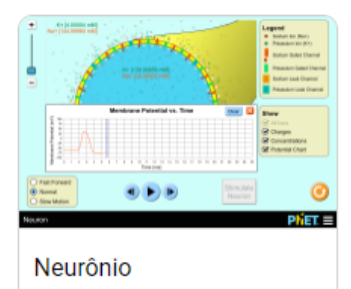

国

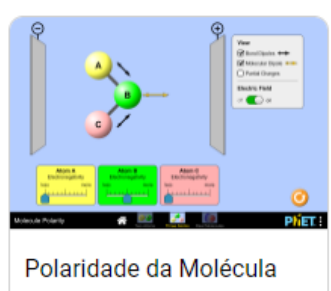

可

29 Physics Educacional Technology (PhET) (https://phet.colorado.edu/pt_BR/). 
Fonte: as autoras, a partir do projeto Physics Educacional Technology (PhET). (https://phet.colorado.edu/pt_BRL), 2021.

Diferentemente das simulações, os laboratórios remotos, ao permitir que o aluno interaja e manipule de forma síncrona e on-line os equipamentos do laboratório virtual, são considerados um tipo de Experimentação Remota (ER).

[...] lidar com experimentos remotos é uma experiência real, pois estes detêm de elementos físicos que interatuam por comandos virtuais. O contato com os experimentos é de forma direta e a resposta obtida é imediata online. Laboratórios Remotos utilizam meios físicos, porém o acesso ao experimento é promovido remotamente (PIERRI et al., 2019, p. 4).

Devido à demanda crescente do uso de laboratórios remotos no mundo, diversos grupos de pesquisa estão desenvolvendo e disponibilizando experimentos remotos em plataformas de modo gratuito. No Brasil, um laboratório relevante é o Laboratório de Experimentação Remota (RExLab), da Universidade Federal de Santa Catarina, que desenvolveu o Remote Labs Learning Environment (RELLE $\left.{ }^{30}\right)$, um ambiente que permite a manipulação e o gerenciamento de experimentos remotos e conta com alguns experimentos voltados para as áreas das Ciências Naturais.

Outro caminho possível está na adaptação de algumas atividades práticas já realizadas na modalidade presencial para o modelo remoto e/ou híbrido. Dependendo do tipo de experimento e do objetivo pedagógico, as práticas podem ser abordadas de diferentes formas. Em atividades simples e sem periculosidade, o aluno pode realizar o experimento em casa seguindo um roteiro orientado, com posterior entrega do relatório contendo as fotos do experimento ${ }^{31}$ e a discussão das questões via AVA, e-mail ou link do Google Docs como sistematização (Figura 7.3); depois, de forma síncrona, ocorre a discussão com o professor e a turma. A prática de desnaturação da proteína da

\footnotetext{
${ }^{30}$ Remote Labs Learning Environment (RELLE; http://relle.ufsc.br/)

31 Como sugestão, solicitar uma foto do aluno junto ao experimento como uma forma de acompanhar a autoria e de fomentar uma aproximação com o professor, ao "personalizar" o estudante.
} 
clara do ovo (albumina) com água quente, álcool e vinagre e do leite (caseína) com limão e vinagre é um exemplo simples para ser realizado pelo estudante em casa. Como método, esse formato de atividade parte dos pressupostos da sala de aula invertida, pois os alunos, com o uso de um roteiro orientado, primeiramente realizam a prática e as pesquisas sozinhos, para depois em sala de aula aprofundar os resultados do experimento, relacionando à teoria.

Figura 3 - Parte do relatório entregue por uma estudante do $2^{\circ}$ ano do Ensino Médio, como exemplo da proposta de realização da atividade prática em casa
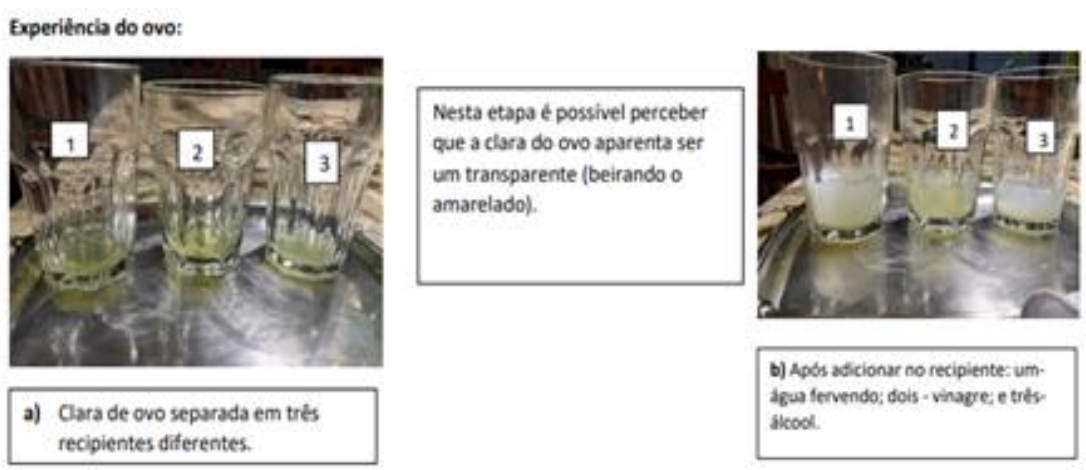

Apos o procedimento, e posshel notar que houve um processo de desnaturacho das proceinas da dara do ovo lato é, as proteinas da clara do ove, antes do experimento ser realizado, possuiam um formato expecifico, o qual os aminoscidos (distantes un do outro) interagiam entre si. Depois da adiclo do produtos, as proteinas perderam o seu formato tridimensional e passaram a ter o formuto ineac; asim, a clara do ovo passou da sa cor criginal ao branco ('esbranquicado').

Fonte: Acervo das autoras, 2021.

Como segundo formato, o qual se assemelha ao método investigativo, o professor pode gravar um pequeno vídeo ou demonstrar de forma síncrona a instalação de um experimento, solicitando aos alunos, individualmente, em duplas ou trios, que formulem hipóteses sobre os resultados do experimento. Para diálogo dentro dos pequenos grupos, eles podem utilizar o WhatsApp e as redes sociais Facebook e Instagram; caso a proposta exija mais tempo de diálogo e o professor queira usar o espaço da aula síncrona para isso e acompanhar o debate, os educandos podem se reunir em salas on-line ${ }^{32}$ previamente montadas.

Dependendo do grau de dificuldade ou de aprofundamento requerido para a atividade, as hipóteses podem ser apresentadas durante a própria aula em

32 O professor pode utilizar diferentes plataformas de comunicação e colaboração on-line, como o Zoom, o Meet ou o Teams. 
que o professor monta o experimento ou enviadas como tarefa extraclasse. Para isso, pode-se utilizar o Padlet, Google Docs ou até mesmo o Socrative, servindo este como um repositório de respostas. Passado o tempo do experimento, durante uma aula síncrona o professor apresenta os resultados e estabelece uma discussão contrapondo as hipóteses. Como fechamento, solicita a sistematização da discussão e aponta algumas questões de aprofundamento, extrapolando os resultados do experimento. Como sugestão de prática, a digestão enzimática da proteína da clara do ovo (cozido), comparando o processo entre três frascos, um com água, outro com suco de limão e outro com suco de abacaxi, cabe bem na proposta (Figura 7.4).

Figura 7.4 - Parte do relatório final entregue por uma dupla de estudantes do 20 ano do Ensino Médio, como exemplo da proposta de realização da atividade prática utilizando o método investigativo

2 Experimento: Clara de ovo - 0 efeito dos ácidos e enzimas

Clara de ovo submersa no suco de limão- Devido ao $\mathrm{pH}$ ácido do suco de limão ( 2), este provocará a quebra das ligações de proteínas do ovo, fazendo com que após o tempo do experimento (48-72 horas), se possa notar que grande parte do ovo foi diluído no suco. Apesar de que o baixo número de enzimas no limão seja uma desvantagem com relação ao abacaxi.

- Resultado: o experimento não apresentou o resultado previsto na hipótese, na realidade o limão não provocou efeito visivel algum na clara de ovo, que permaneceu a mesma após o tempo do experimento, provando que a acidez do limão não é suficiente para alterar visivelmente uma proteína previamente desnaturada.

Clara de ovo submersa no suco de abacaxi- Devido ao pH ácido do suco de abacaxi ( 3,5$)$, este provocará a quebra das ligações da proteína do ovo, além disso, a alta concentração de enzimas fará com que a "pseudo-digestão" da clara de ovo no suco de abacaxi seja tão rápida quanto, ou até mais rápida e intensa que sua homônima no suco de limão, fazendo com que ao término do tempo do experimento (48-72 horas) o ovo esteja em grande parte diluído no suco.

- Resultado: o resultado do experimento foi em parte o esperado, pois o suco de abacaxi gerou efeitos maiores que o previsto, dissolvendo uma enorme parte da clara do ovo, além disso tais efeitos foram causados não pela acidez da fruta, e sim por suas enzimas, provando que subestimei os efeitos delas assim como superestimei o efeito do ácido.

Clara de ovo submersa na água - Devido ao pH neutro (somente se destilada, caso contrário é levemente ácida) da água, além da ausência de enzimas, esta não provocará a quebra das ligações da proteína do ovo, logo, passado o tempo do experimento (48- 72 horas) não haverá efeitos visiveis no objeto do experimento (no caso, clara de ovo).

- Resultado: a água gerou exatamente o efeito esperado, ou seja, nenhum, minha hipótese se provou correta, pois a água não possui acidez nem enzimas, logo, não possui meio algum para dissolver proteínas, portanto, obviamente não o faz.

Fonte: Acervo das autoras, 2021. 
O terceiro formato não foge à regra do que é comumente trabalhado no ensino presencial: o uso de experimentos para comprovação e demonstração de fenômenos, configurando-se como uma aula teórico-prática. A diferença é a necessidade de preparação do material com antecedência e recursos audiovisuais adequados. Durante a aula, o professor apresenta um experimento em funcionamento, comprovando a teoria ou explicando e fazendo indagações sobre o processo visualizado. A demonstração da fotossíntese, por meio da liberação de oxigênio das folhas de Elodea sp., é uma possibilidade.

Os três formatos de atividades práticas apresentados foram utilizados durante o ano de 2020, com estudantes do $2^{\circ}$ ano do Ensino Médio de uma escola particular de Curitiba (PR); como feedback, os estudantes apontaram a relevância das atividades para a aprendizagem dos conteúdos de bioquímica, fisiologia humana e metabolismo energético (fotossíntese). Ao mesmo tempo, durante conversas informais, foi lembrada a importância do professor junto da confecção e discussão, resultando na preferência pelos modelos dois (investigativo) e três (teórico-prático). Quanto ao modelo um, do fazer em casa e que flerta com a sala de aula invertida, a ressalva foi apresentada devido a não saberem visualmente o que esperar do experimento e a terem que sozinhos organizar os materiais, a bancada e depois discutir o resultado relacionando aos conteúdos abordados durante as videoaulas ou mediante pesquisa em fontes indicadas pelo professor. Essa colocação dos alunos retrata a insegurança e dificuldade que eles possuem em ser protagonistas do próprio processo de ensino-aprendizagem, refletindo toda a sua vida escolar, em que possivelmente estão habituados com aulas práticas centradas em um roteiro direcionado e com o professor acompanhando o passo a passo dos experimentos, muito diferente do que a atividade propõe.

A última proposta didática a ser apresentada é uma adaptação do que foi desenvolvido pelas professoras Anna Legroski e Nicole Witt (2019). Nessa atividade, os alunos receberam um estudo de caso de doenças virais, bacterianas ou protozoonoses e em grupo construíram um enredo narrativo verossímil aos conhecimento biológicos de contágio, profilaxia e prognóstico, 
mas também estruturado na forma de romances de tese, que, segundo Massaud Moises (1974, apud LEGROSKI; WITT, 2019), é "uma narrativa comportando uma doutrina, geralmente explícita, emprestada de uma forma de conhecimento não-estético, que o escritor encampa e forceja por divulgar ou corporificar através de uma adequada fabulação". Como produto final, os alunos apresentaram as narrativas a partir da arte sequencial e da linguagem não verbal na forma de história em quadrinhos.

Em sala de aula ou com recursos digitais, é possível manter a proposta da história em quadrinhos, mas também é possível adaptar a metodologia para uma narrativa literária construída coletivamente dentro do AVA, como, por exemplo, no Moodle, via wiki, ou facilmente via Google Docs, com construção do texto de forma on-line, em momentos síncronos e assíncronos, pelos estudantes do mesmo grupo.

Dentro das possibilidades apontadas para o cenário vigente, é importante a compreensão de que

a ênfase não está na tecnologia, sendo que esta atua como um ambiente promotor de redes de aprendizagem e conhecimento. $\mathrm{O}$ foco precisa estar nas condições que afetam a apropriação tecnológica, importando consigo um significativo incremento do sentido e da qualidade na educação. A tecnologia sozinha não muda as práticas pedagógicas, sendo que para maximizar os benefícios da inovação tecnológica, principalmente os que se referem as TD [tecnologias digitais], importa alterar a forma como se pensa a educação. (MOREIRA; SCHLEMMER, 2020, p. 6).

Como percepções finais, fica claro que, para a implementação de novos modelos educativos, o saber tecnológico sozinho não move moinhos; para isso, não só os educadores, mas também os educandos, precisam rever os seus papéis durante o processo de ensino e aprendizagem. 


\section{O ENSINO DE GEOGRAFIA NO CONTEXTO DA PANDEMIA DA COVID-19}

Da mesma forma que no ensino de Ciências e Biologia, a pandemia da Covid-19 trouxe reflexões sobre o ensino de Geografia e estimulou as comparações do que pode ser utilizado como estratégia pedagógica no formato presencial e no formato remoto emergencial. Dessa perspectiva, serão apresentadas algumas sugestões de estratégias e recursos para o ensino de Geografia que o professor poderá fazer uso durante e após a pandemia.

A primeira atividade pedagógica sugerida, que pode ser desenvolvida tanto no formato presencial quanto no remoto emergencial, é a aula de campo. No ensino presencial, quando o professor planeja uma aula de campo, com visitas a parques, indústrias, museus, entre outros, precisa organizar toda a atividade, desde o planejamento pedagógico e os objetivos de aprendizagem a ser alcançados até a logística da excursão, com os valores, horário de saída e retorno, custos, lanches, autorização dos pais, enfim, um planejamento completo para executar o passeio de maneira organizada e didaticamente correta.

No formato do ensino remoto emergencial, é possível escolher um museu interativo virtual e organizar o passeio on-line. A organização deve ser realizada com antecedência para orientar os alunos a acompanhar o passeio, seguindo e observando elementos que o professor pretende destacar e explicar, como, por exemplo, a explicação dos tipos de rochas, minerais metálicos e não metálicos ao entrar no Museu de Mineralogia de Minas Gerais. É importante salientar que essas atividades trazem uma vivência prática para o aluno. A elaboração de um relatório de todos os pontos visitados, relevantes para a ampliação do conhecimento do estudante, é uma excelente atividade de sistematização que exercita também a escrita e a organização do seu pensamento.

A visita virtual pode ser roteirizada, passo a passo, e feita sob a orientação do professor, durante a aula remota, mas pode também ser realizada de modo autônomo pelo estudante, em horário alternativo, tendo como atividade 
posterior a entrega do relatório. No Quadro 7.1, algumas sugestões de museus importantes que apresentam visita virtual. Numa busca simples na internet, os professores poderão encontrar muitos outros espaços culturais que possibilitam visitas virtuais, dentro e fora do Brasil.

Quadro 7.1 - Indicação de museus que apresentam visita virtual e que podem ser abarcados junto da disciplina Geografia

\begin{tabular}{|c|c|}
\hline Local & Endereço eletrônico \\
\hline Museu Virtual do Transporte & $\begin{array}{l}\text { http://www.museudantu.org.br/princip } \\
\text { al.asp }\end{array}$ \\
\hline Museu do Índio & $\begin{array}{l}\text { http://www.museudoindio.gov.br/visit } \\
\text { as/visita-virtual }\end{array}$ \\
\hline Museus e exposições em Minas Gerais & https://www.eravirtual.org/ \\
\hline Museu da República & $\begin{array}{l}\text { http://www.eravirtual.org/mrepublica_ } \\
01 \_b r /\end{array}$ \\
\hline $\begin{array}{l}\text { Tour virtual ao Museu Geológico da } \\
\text { Bahia }\end{array}$ & $\begin{array}{l}\text { https://www.youtube.com/watch?v=e } \\
5 \mathrm{krC5fBqJs}\end{array}$ \\
\hline $\begin{array}{l}\text { Museu de Geociências da Universidade } \\
\text { de Brasília }\end{array}$ & $\begin{array}{l}\text { http://www.museuvirtual.unb.br/index } \\
\text {.php?option=com_k2\&view=item\&id=3 } \\
\text { :geociencias }\end{array}$ \\
\hline
\end{tabular}

Fonte: as autoras, 2021

Para visitar espaços culturais fora do território nacional, é preciso verificar se essas visitas têm como idioma disponível o português. Apenas em escolas bilíngues os professores encontrarão um pouco de flexibilidade nesse contexto.

Outro recurso didático pedagógico que pode ser utilizado em aulas presenciais ou remotas são as animações, porém, para produzi-las, é necessário que o professor tenha facilidade na lida com os recursos digitais, 
como o Powtoon ${ }^{33}$. Com essa plataforma, é possível produzir gratuitamente animações e vídeos explicativos.

Figura 7.5 - Exemplo de produção possível de ser realizada com a utilização do

\section{Powtoon}

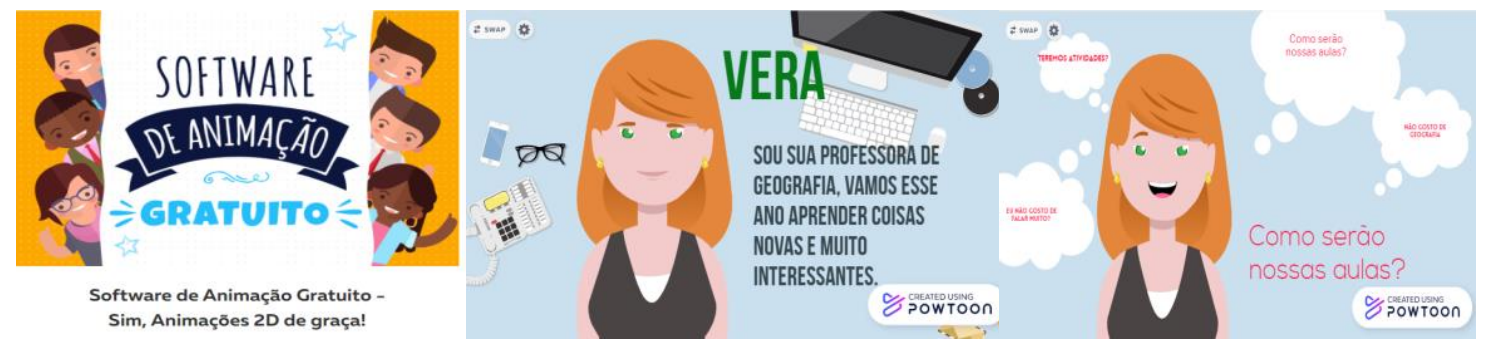

Fonte: As autoras, 2021. Adaptado de Powtoon (www.powtoon.com)

A produção desse tipo de atividade requer tempo, porém possibilita criar um portfólio de atividades próprias e utilizá-las no ano seguinte. Assim que elaborar seu portfólio, poderá usar o mesmo material em turmas de anos seguintes; como uma animação produzida neste ano sobre os diferentes tipos de rocha poderá ser utilizada várias vezes, lembre-se de produzir um material atemporal. Nesse caso, é importante realizar uma verificação contínua sobre a atualização do conteúdo em estudo. Existem conteúdos que sofrem poucas modificações, geralmente os relativos às dinâmicas da natureza. Entretanto, outros, especialmente os referentes às dinâmicas da sociedade, devem ser sempre atualizados, tanto em termos conceituais quanto de dados estatísticos.

Um dos mais conhecidos e preferidos entre os recursos didáticos lúdicos são os jogos, que podem ser utilizados tanto no ensino presencial quanto no remoto. Existem jogos já prontos na internet, mas normalmente não contemplam fielmente o conteúdo que se está trabalhando. Por conta disso, é interessante que o professor monte seus próprios jogos ou o faça em conjunto com os estudantes.

\footnotetext{
33 https://www.powtoon.com
} 
No site Wordwall ${ }^{34}$ por exemplo, é possível montar quiz, diagramas rotulados, palavras cruzadas, caça-palavras, entre outros jogos que, com o conteúdo correto e adequado, poderão, além de motivar os estudantes, facilitar a compreensão dos conteúdos abordados. O site disponibiliza uma conta gratuita, com um pouco menos de recursos, porém com boas possibilidades de exploração.

Figura 7.6 - Exemplos de atividades elaboradas

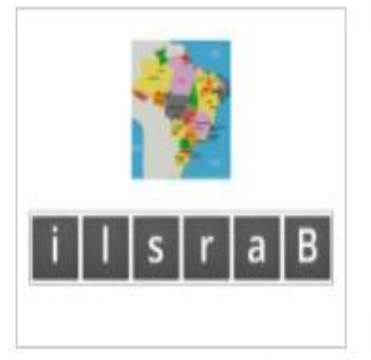

Independência do Brasil

Anagrama por Ticonsabrina

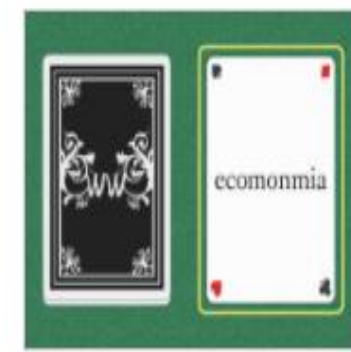

Brasil

Cartôes aleatórios

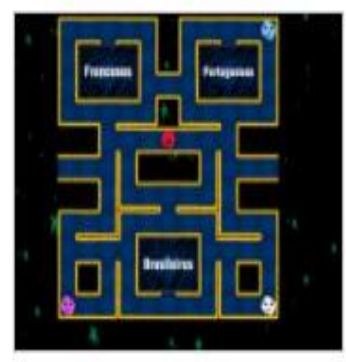

Brasil

Perseguição do labirinto

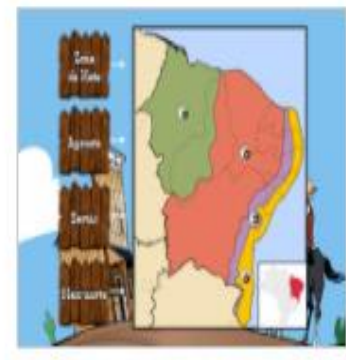

No Brasil, a região Nordeste é dividida repectivamente...

Fonte: Wordwall https://wordwall.net/pt, 2021

Figura 7.7 - Diversas possibilidades de criação

\footnotetext{
34 https://wordwall.net/pt
} 


\begin{tabular}{|c|c|c|c|c|c|}
\hline \multirow{2}{*}{ - INTERATIVOS } & & & Você usou 1 de seus recursos 5 & \multirow{2}{*}{\multicolumn{2}{|c|}{ Ordenar por. MAIS POPULARES ALFABÉTICA }} \\
\hline & & & & & \\
\hline 모요 & $\begin{array}{l}\text { Quiz } \\
\text { Uma série de perguntas de mútipla escolha. Toque } \\
\text { na resposta correta para prosseguir. }\end{array}$ & 圖圆 & $\begin{array}{l}\text { Combinar } \\
\text { Arraste e solte cada palavra-chave ao lado de sua } \\
\text { definiçâo. }\end{array}$ & 80 & $\begin{array}{l}\text { Roda aleatória } \\
\text { Gire a roda para ver qual item aparece em seguida. }\end{array}$ \\
\hline 340 & $\begin{array}{l}\text { Abra a caixa } \\
\text { Toque em cada caixa de cada vez para abrir e revelar } \\
\text { o item de dentro. }\end{array}$ & 响 & $\begin{array}{l}\text { Pares correspondentes } \\
\text { Toque em ump par de telhas de cada vez para revelar } \\
\text { se elas se correspondem. }\end{array}$ & 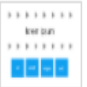 & $\begin{array}{l}\text { Encontre a partida } \\
\text { Toque na resposta correspondente para eliminá.la. } \\
\text { Repita até que todas as respostas desapareçam. }\end{array}$ \\
\hline 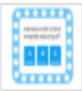 & $\begin{array}{l}\text { Quiz no formato programa de televisão } \\
\text { Um quiz de múltipla escolha com contagem de } \\
\text { tempo, linhas da vida e uma rodada de bônus. }\end{array}$ & 量要 & $\begin{array}{l}\text { Tipo de grupo } \\
\text { Arraste e solte cada item em seu grupo } \\
\text { correspondente. }\end{array}$ & Pr? & $\begin{array}{l}\text { Diagrama rotulado } \\
\text { Arraste e solte os pinos no lugar correto na imagem. }\end{array}$ \\
\hline & $\begin{array}{l}\text { Caça-palavras } \\
\text { As palavras estâo escondidas em uma grade de } \\
\text { letras. Encontre-as o mais rápido que puder. }\end{array}$ & $=$ & $\begin{array}{l}\text { Palavra faltante } \\
\text { Uma atividade de conclusäo em que você arrasta e } \\
\text { solta palavras em espaços em branco dentro de um } \\
\text { texto. }\end{array}$ & 四解 & $\begin{array}{l}\text { Desmaranhar } \\
\text { Arraste e solte palavras para reorganizar cada frase } \\
\text { em sua ordem correta. }\end{array}$ \\
\hline & $\begin{array}{l}\text { Cartões aleatórios } \\
\text { Distribua os cartões aleatoriamente de um baralho } \\
\text { misturado. }\end{array}$ & 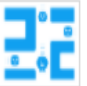 & $\begin{array}{l}\text { Perseguição do labirinto } \\
\text { Corra para a zona de resposta correta, evitando os } \\
\text { inimigos. }\end{array}$ & 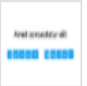 & $\begin{array}{l}\text { Anagrama } \\
\text { Arraste as letras para suas posiçoes corretas para } \\
\text { descodificar a palavara ou frase. }\end{array}$ \\
\hline & $\begin{array}{l}\text { Whack-a-mole } \\
\text { Toupeiras aparecem uma de cada vez; acerte apenas } \\
\text { as corretas para ganhar. }\end{array}$ & 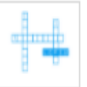 & $\begin{array}{l}\text { Palavras cruzadas } \\
\text { Use as pistas para resolver as palavras cruzzadas. } \\
\text { Toque em uma palavra e digite a resposta. }\end{array}$ & 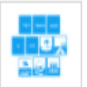 & $\begin{array}{l}\text { Vire as telhas } \\
\text { Explore uma série de telhas de dois lados tocando } \\
\text { para ampliar e golpeando para virar. }\end{array}$ \\
\hline
\end{tabular}

Fonte: Wordwall

https://wordwall.net/pt,2021) 
Figura 7.8 - Exemplo de montagem e envio
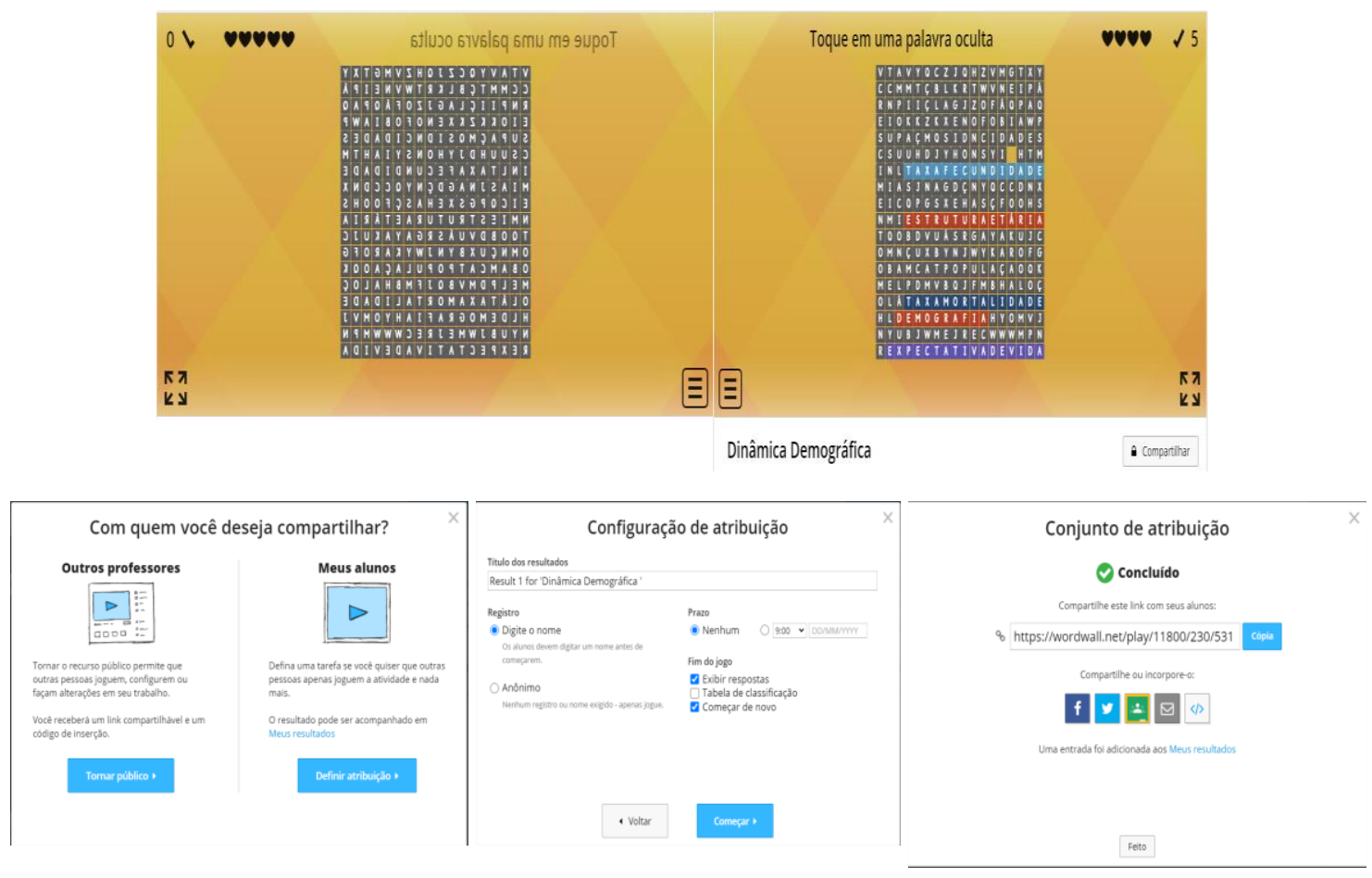

Fonte: Wordwall https://wordwall.net/pt), 2021

Para os alunos do Ensino Médio, devido à maior capacidade de abstração, sugere-se que os professores os desafiem a montar os jogos de acordo com o conteúdo estudado em determinado período. Pode-se usar uma aula para que todos apresentem os seus jogos e eles possam interagir com a produção dos próprios colegas. Lembre-se de organizar essa troca de experiências para evitar que ocorra troca de jogos somente entre os colegas mais próximos.

Ainda sobre o site Wordwall, há materiais prontos sobre os seguintes conteúdos de Geografia: a Organização das Nações Unidas, globalização e meio ambiente, os agentes endógenos e do relevo, entre outros. Assim, é fundamental que o professor verifique e pesquise 0 que existe pronto para uso para definir o que precisa montar e criar a partir de suas necessidades pedagógicas, de acordo com o seu planejamento de ensino. Em geral, esse site é de simples compreensão e interativo, mas, caso encontre alguma dificuldade, é possível buscar por tutoriais em sites como o YouTube para auxiliar nessas tarefas. 
Outra sugestão de ferramenta, ainda no contexto dos jogos didático-pedagógicos, é o PowerPoint, muito conhecido por estudantes e professores, que oferece a possibilidade de gamificação de alguns conteúdos. É possível usá-lo para criar quiz, jogos de roleta, mapas mentais, linha do tempo, fluxograma, entre outras atividades. 0 importante é conhecer os recursos para que se possa fazer uso deles. No site Slidesgo ${ }^{35}$ encontram-se alguns tutoriais sobre recursos e modelos para montar as apresentações. Os recursos do PowerPoint são mais limitados que os do site apresentado anteriormente, mas é importante salientar que a melhor plataforma sempre será aquela de que o usuário tem mais conhecimento ou preferência. Lembre-se de que as opções se multiplicam na internet, algumas trazendo mais recursos e facilitando a utilização.

Ainda no contexto dos jogos, uma atividade muito aplicada no ensino da Geografia é o jogo de perguntas e respostas, também conhecido como quiz. É importante estimular os estudantes a participar, afinal é uma brincadeira e eles irão brincar e aprender ao mesmo tempo; quem não gosta de um jogo de perguntas e respostas? Fora da escola, há vários jogos, como o famoso Jogo do Milhão (Silvio Santos), em que o boneco faz perguntas para que os participantes, cada um na sua vez, respondam e marquem pontos. Como exemplo mais atual desse tipo de jogo, há o Perguntados, que se trata de um aplicativo de celular composto por questões que envolvem diversos campos do conhecimento, inclusive a Geografia.

35 https://slidesgo.com/pt/jogo 
Figura 7.9 - Imagens do aplicativo Perguntados

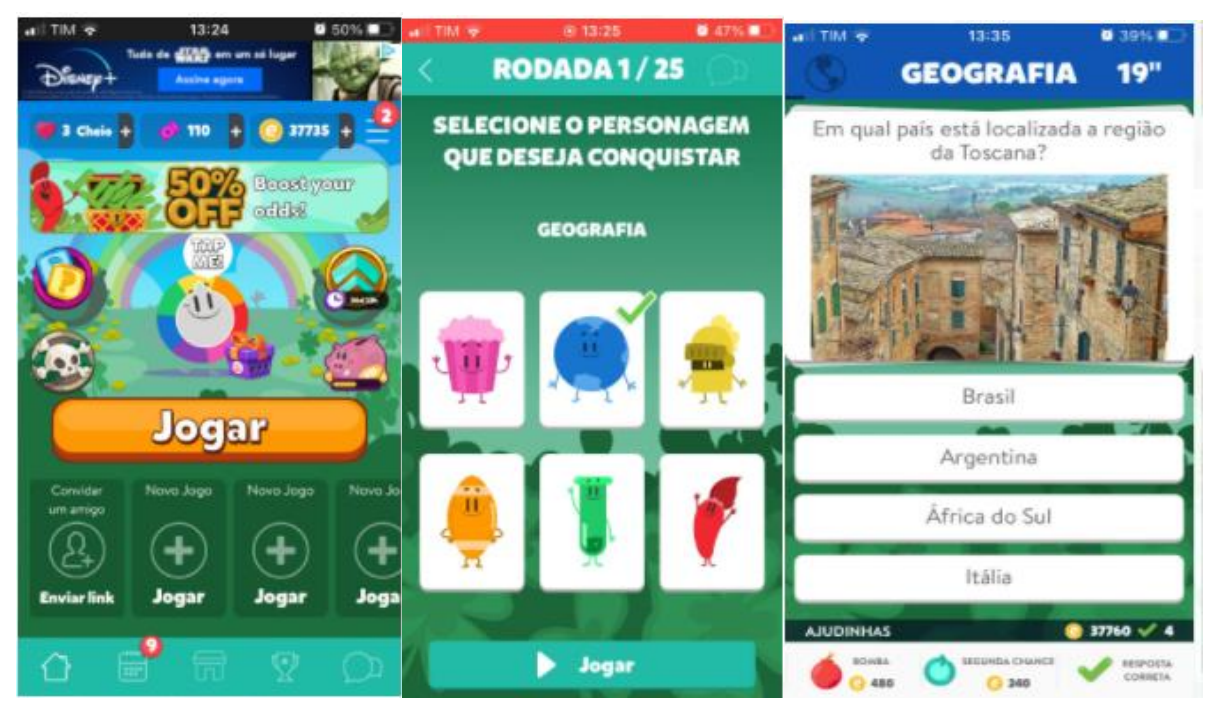

Fonte: site Slidesgo (https://slidesgo.com/pt/jogo) ${ }^{36}, 2021$.

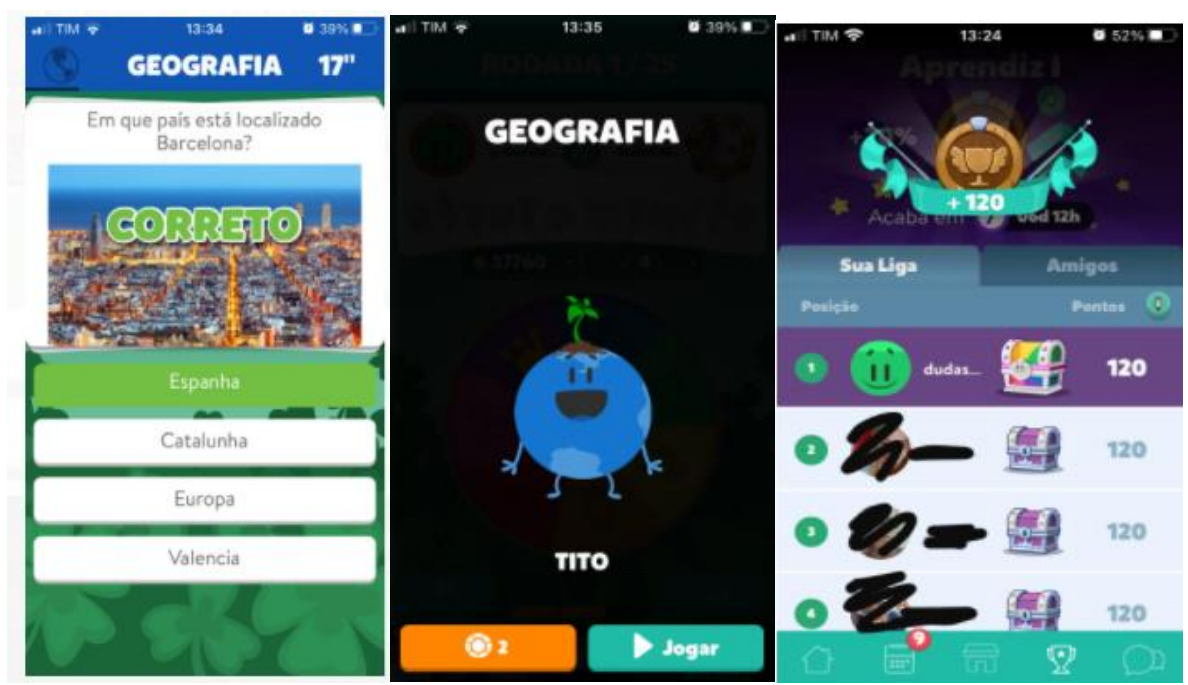

Fonte: site Slidesgo (https://slidesgo.com/pt/jogo), 2021

No campo pedagógico das metodologias ativas, a preparação para qualquer atividade de ensino requer o protagonismo do estudante. Por isso, a última sugestão discutida neste texto requer uma preparação prévia da turma para que os estudantes exerçam papel ativo no processo de ensino-aprendizagem. Dessa perspectiva, será apresentada uma sugestão de atividade que pode ser utilizada no ensino presencial e no remoto emergencial, fundamentada na

\footnotetext{
36 Todos os recursos digitais mencionados neste texto estão relacionados num quadro-resumo, no Apêndice I.
} 
proatividade do estudante, com o propósito de estimular sua curiosidade, de mobilizá-lo para pesquisa em busca de determinado conhecimento.

O planejamento do professor deve iniciar pela definição do conteúdo a ser estudado, tempo que será dedicado à atividade, organização da turma em equipes, número de alunos por equipe, tempo que cada equipe terá para responder a cada questão e pontuação ou possível recompensa pelo acerto das respostas. É importante que o professor tenha um banco de dados bem formulado sobre os conteúdos envolvidos nessa prática. Além disso, deve passar para os alunos os conteúdos que serão cobrados com antecedência; solicitar pesquisa sobre eles e indicar fontes, que podem ser livros, mapas, apostilas, resumos, internet, entre outras; elaborar questões de acordo com a dificuldade que deseja atribuir ao jogo e, principalmente, a idade e conhecimento dos alunos.

$\mathrm{Na}$ execução da atividade propriamente dita, deve marcar o tempo que cada equipe terá para responder às perguntas, deixando o relógio ou cronômetro visível a todos; realizar a pergunta pausadamente e repetir duas vezes a mesma questão. É importante dar um gatilho (valendo), para que iniciem a pesquisa. O docente também deve determinar o tempo de pesquisa de acordo com o material permitido e a idade dos alunos. Na primeira rodada, a equipe 1 responde primeiro; caso não responda, passa para a equipe 2 e assim sucessivamente. Na segunda rodada, a equipe 2 responde primeiro; caso não responda passa para a equipe 3 e assim sucessivamente.

Essa atividade pode ser organizada de diversas formas dentro de sala ou mesmo de maneira on-line. Na forma on-line, pode-se delimitar determinado tempo para enviar a resposta de diversas questões, como em um combo; nesse caso, o resultado sai posteriormente, dependendo do número de acertos e do tempo de envio das respostas de cada equipe. Toda a dinâmica irá depender das regras escolhidas 
pelo professor mediador da atividade, devendo-se levar em conta, no planejamento, o tempo de pesquisa e o material a ser pesquisado.

Não importa a forma que o professor irá escolher para realizar essa ou qualquer outra atividade que envolva metodologias ativas, o importante é não deixar de fazer a análise junto aos estudantes de como foi a experiência educativa vivida. Para isso, sugere-se solicitar que expressem como foi a aquisição de conhecimentos novos por meio de podcasts, vídeos, fôlderes, elaboração de jogos e, em certos casos, até uma apresentação.

Destaca-se que existem outras metodologias ativas, entre elas, os modelos de rotação por estações, a sala de aula invertida e o laboratório rotacional, todas com o potencial de utilização no ensino presencial, no ensino híbrido ou no remoto emergencial. A criatividade do educador em fazer uso das metodologias ativas para estimular a participação dos alunos, tendo como pressuposto a particularidade de cada modalidade e grupo de educandos, fará a diferença.

\section{CONSIDERAÇÕES FINAIS}

Diante do cenário vigente, de mudanças emergenciais na forma de ensinar e aprender e que se configuram como, ao menos em parte, propostas para os anos subsequentes, diálogos e abertura para o novo se fizeram e se fazem necessários. Dentro disso, a comunidade escolar precisa ser escutada, tanto quanto aos seus anseios quanto a estratégias possíveis, pois cabe a ela a ação de implantar e experienciar o cotidiano dessas mudanças. A nova práxis educacional, o novo fazer educativo deve ser construído de forma coletiva e democrática, respeitando as particularidades dos sujeitos e das diferentes realidades que permeiam as diversas escolas e comunidades, bem como as etapas (Educação Infantil, Ensino Fundamental e Ensino Médio) da educação básica. Será fundamental nesse processo o envolvimento, também, das diferentes equipes de 
gestão que se encontram nas escolas: pedagógica, administrativa, financeira e de comunicação, que precisam trabalhar em harmonia com professores e toda a comunidade para alcançar a educação de qualidade nesse período.

Ao mesmo tempo, a abertura para o novo não significa a extinção do velho, pois, de tudo que foi apreendido no ano de 2020, permanece a concepção de que as relações humanas, tão fortemente vividas durante o processo de ensino-aprendizagem, estão para além das interfaces virtuais e que sem elas não há construção do conhecimento, pois esta precisa ser coletiva e ocorrer nas interações entre os sujeitos. Os recursos tecnológicos, vistos inicialmente como a salvação do processo, continuam como instrumentos importantes e hoje imprescindíveis, mas sozinhos são meras ferramentas. Portanto, o papel do educador, professor, se por algum momento foi pensado como obsoleto, agora ressurgiu como peça fundamental para a continuidade de uma educação inovadora e voltada para novas formas de ensino, com uso das tecnologias como forma de motivar os alunos a compreender, procurar por novos conhecimentos e ter prazer em estudar e aprender.

\section{REFERÊNCIAS}

AGUIAR, Eliane Vigneron Barreto; FLÔRES, Maria Lucia Pozzatti. In. TAROUCO, Liane Margarida Rockenbach. Objetos de Aprendizagem: teoria e prática/ Organizadores Liane Margarida Rockenbach Tarouco, Bárbara Gorziza Ávila, Edson Felix dos Santos e Marta Rosecler Bez, Valeria Costa. Porto Alegre: Evangraf, 2014. ALVES, L. Educação Remota: entre a ilusão e a realidade. Interfaces Científicas. Aracaju V.08, N.3, p. 348-365, 2020.

BRASIL, Todos pela Educação. Nota Técnica - Análise: Ensino a distância na Educação Básica frente a Pandemia da Covid19. Abril, 2020.

BRASIL. Lei de Diretrizes e Bases da Educação Nacional, LDB. 9394/1996.

BRASIL. Decreto No 9.057, de 25 de maio de 2017. Regulamenta o art. 80 da Lei no 9.394, de 20 de dezembro de 1996, que estabelece as diretrizes e bases da educação nacional. Brasília, DF, 2017.

LEGROSKI, Anna Carolina; WITT, Nicole Geraldine de Paula Marques. Diálogos e interseções entre estudos de casos parasitológicos e narrativas de ficção no Ensino Médio. In. EDUCERE. XIV Congresso Nacional de Educação [Anais], CuritibaPR, p. 2807-2809, set. 2019. MOREIRA, José Antonio; SCHLEMMER, Eliane. Por um novo conceito e paradigma de educação digital onlife. Revista UFG, v. 20, p. 2-35. 2020. 
SANTANA, C. L. S. e; SALES, K. M. B. Aula em casa: educação, tecnologias digitais e pandemia covid-19. Interfaces Científicas. Aracaju v.10, n.1, p. 75 - 92, 2020. PIERRI, Leonardo Deivid; DORNELES, Rodrigo Kenig; MENDONÇA, Igor Thiago Marques; GRUBER, Crislaine. Experimentação Remota como estratégia para o Ensino Híbrido. In. 240 Seminário Internacional de Educação, Tecnologia e Sociedade: Ensino Híbrido. Núcleo de Educação On-line FACCAT, nov. 2019.

\section{APÊNDICE I}

Quadro 7.2 - Recursos digitais e objetos educacionais referenciados no texto.

\begin{tabular}{|c|c|c|}
\hline Recurso & Descrição & Endereço \\
\hline Google Docs & $\begin{array}{lr}\text { Permite } & 0 \\
\text { compartilhamento de } \\
\text { material on-line e/ou a } \\
\text { construção coletiva de } \\
\text { textos (Word), planilhas do } \\
\text { Excel e apresentação } \\
\text { (PowerPoint), de forma } \\
\text { síncrona ou assíncrona. }\end{array}$ & $\begin{array}{l}\text { https://www.google.com/intl/ } \\
\text { pt-BR/docs/about/ }\end{array}$ \\
\hline Padlet & $\begin{array}{lr}\text { Ferramenta } & \text { on-line que } \\
\text { permite a criação de murais } \\
\text { interativos, para registrar, } \\
\text { guardar e partilhar } \\
\text { informações. } & \text { Funciona } \\
\text { como uma folha de papel na } \\
\text { qual você } & \text { partilha } \\
\text { informações } & \text { (textos, } \\
\text { imagens, animações, } \\
\text { hiperlinks) com outras } \\
\text { pessoas. }\end{array}$ & $\begin{array}{l}\text { https://pt-br.padlet.com/ } \\
\text { Tutorial: } \\
\text { https://site.educacao.go.gov. } \\
\text { br/wp- } \\
\text { content/uploads/2020/04/CO } \\
\text { MO-CONSTRUIR-E-UTILIZAR- } \\
\text { O-APLICATIVO-PADLET.pdf }\end{array}$ \\
\hline Powtoon & $\begin{array}{l}\text { Plataforma de comunicação } \\
\text { para a criação de vídeos e } \\
\text { animações personalizados. }\end{array}$ & https://www.powtoon.com/ \\
\hline PhET & $\begin{array}{l}\text { Repositório on-line e } \\
\text { gratuito de simulações } \\
\text { virtuais sobre diversos } \\
\text { fenômenos das ciências } \\
\text { naturais e de ciências da } \\
\text { terra. }\end{array}$ & $\begin{array}{l}\text { https://phet.colorado.edu/pt } \\
\text { BR/ }\end{array}$ \\
\hline RELLE & $\begin{array}{l}\text { Ambiente virtual que } \\
\text { permite a manipulação e o } \\
\text { gerenciamentor de } \\
\text { experimentos remotos. } \\
\text { Contempla alguns voltados } \\
\text { para a área de ciências da } \\
\text { natureza. }\end{array}$ & http://relle.ufsc.br/ \\
\hline
\end{tabular}




\begin{tabular}{|c|c|c|}
\hline Slidesgo & $\begin{array}{l}\text { Com modelos de } \\
\text { apresentação de jogos, } \\
\text { permite criar atividades } \\
\text { divertidas sobre temas que } \\
\text { podem contemplar suas } \\
\text { aulas. São apresentações } \\
\text { para o Google e } \\
\text { PowerPoint. }\end{array}$ & https://slidesgo.com/pt/jogo \\
\hline Socrative & $\begin{array}{l}\text { Aplicativo on-line para a } \\
\text { construção de questionários } \\
\text { que podem ser resolvidos } \\
\text { de forma síncrona com o } \\
\text { professor (momento da } \\
\text { aula) ou assíncrona } \\
\text { (extraclasse). }\end{array}$ & https://www.socrative.com/ \\
\hline Wordwall & $\begin{array}{l}\text { Plataforma para a criação } \\
\text { de quiz, competições, jogos } \\
\text { de palavras e outros, de } \\
\text { forma personalizada. }\end{array}$ & https://wordwall.net/pt \\
\hline
\end{tabular}

Fonte: as autoras, 2021 


\section{CAPÍTULO 8 - CONTRIBUIÇÕES DA EJA PARA CIDADANIA COMPETENTE}

MARIA TEREZA XAVIER CORDEIRO ${ }^{37}$

Este capítulo trata da Educação de Jovens e Adultos (EJA) e discute quais são os desafios para os professores, para os alunos e para a sociedade diante das características sociais, culturais e políticas do ensino para essas classes etárias. Problematiza-se a crise da Covid19, reforçando a necessidade de uma educação para a sustentabilidade. Conclui-se que uma adequada educação para os adultos contribui para a construção de um mundo que pode ser desafiado para ser transformado em um mundo melhor.

\section{A EJA COMO LEGADO DA EDUCAÇÃo POPULAR}

O ensino é uma prática social, não só porque se concretiza na interacç̧ão entre professores e alunos, mas também porque estes actores refletem a cultura e contextos sociais que a pertencem. (GIMENO SACRISTÁN, 1995, p. 66)

A EJA é uma modalidade educacional estabelecida pela Lei de Diretrizes e Bases da Educação Nacional (LDB), em seu art. 37: "A educação de jovens e adultos será destinada àqueles que não tiveram acesso ou oportunidade de estudos no ensino fundamental e médio na

37 Graduada em Ciências Biológicas pela UFPR (1985). Especializada em Educação Currículo e Prática Educativa pela PUC-Rio. Atualmente, é coordenadora e professora no Centro Universitário Internacional Uninter, onde atua na EJA a distância. 
idade própria" (BRASIL, 1996). Além de nomeada pela LDB, esta considera seus alunos como sujeitos sociais e culturais, com suas especificidades de educação.

Incorporada às políticas públicas, a EJA é uma herança de um dos movimentos pedagógicos mais questionadores, a educação popular. Com a difícil tarefa de preservar o legado popular, oficialmente tende a ser mais Ensino Fundamental e Médio do que adequada aos seus demandantes. Desenvolvida nas décadas de 1950 e 1960, a educação popular tinha como público-alvo os mesmos jovens e adultos da atualidade: desempregados, excluídos, pobres, batalhadores pelo trabalho e pela vida.

Ter como objetivo principal o jovem e o adulto, com suas características, deve ser a linha norteadora da metodologia para a EJA. Não reduzir a questão educativa a conteúdos mínimos, carga horária predeterminadas, níveis, regimentos, provas e demais formalidades é garantir a continuidade das concepções humanistas de educação construídas nas experiências da educação popular. Ainda, incorporar as concepções de educação e formação humana ao Ensino Fundamental e Médio e não exigir que a EJA se encaixe em modelos e concepções de educação das modalidades de estudo regulares violenta a estrutura escolar como está posta. Mais que Ihes dar oportunidades de prosseguimento aos estudos regulares, considerar experiências de EJA que adequam projetos educativos às condições dos jovens e adultos é legitimar a condição dos seus estudantes.

Reconhecer a escola como tempo e espaço educativos, formadores e culturais, mas não únicos, e tratar a EJA de forma mais plural a partir de projetos que incorporam saberes e conhecimentos mais humanos aumenta a força contra a estreiteza e rigidez das "grades curriculares". Projetos que repensam práticas clássicas, como a verificação de aproveitamento de estudos, sequência curricular por 
séries, cumprimento de cargas horárias por disciplina etc., devem ser desenvolvidos para que possamos garantir formação ao conhecimento, à cultura, à dignidade e à emancipação.

\title{
POLÍTICAS PÚBLICAS
}

\begin{abstract}
A educação de adultos torna-se mais que um direito: é a chave para o século XXI; é tanto consequência do exercício da cidadania como condição para uma plena participação na sociedade. Além do mais, é um poderoso argumento em favor do desenvolvimento ecológico sustentável, da democracia, da justiça, da igualdade entre os sexos, do desenvolvimento socioeconômico e científico, além de um requisito fundamental para a construção de um mundo onde a violência cede lugar ao diálogo e à cultura de paz baseada na justiça (Declaração de Hamburgo sobre a EJA, 1999).
\end{abstract}

As inovações do mundo contemporâneo globalizado requerem competências cada vez mais ligadas aos conhecimentos científicos. As pessoas que não têm acesso aos saberes básicos são excluídas do mercado de trabalho, por isso uma das funções da EJA é ser reparadora (Parecer CNE no 11/2000). Reparar a educação que os jovens e adultos não tiveram na idade adequada significa dar nova oportunidade com qualidade, a fim de que esses sujeitos possam ingressar/reingressar no mundo do trabalho, na vida social e cultural e ter subsídios para pertencer a diversos canais de participação.

Os indivíduos da EJA buscam reestabelecer sua formação para chegar a um ponto de equilíbrio com os demais atores da sociedade. Essa função equalizadora é outro dos objetivos dessa modalidade educacional. O jovem e o adulto, retomando seu potencial e desenvolvendo competências e habilidades na escola ou confirmando as adquiridas durante a vida, se qualificam para o mundo do trabalho. A função qualificadora, que deve ser permanente na EJA, é a de 
propiciar a atualização dos conhecimentos, o que deve acontecer em todas as idades para o desenvolvimento e construção de conhecimentos, habilidades e atitudes para si e para o reconhecimento do outro.

Sendo uma política de Estado, o governo, como responsável por estimular e viabilizar o acesso e a permanência dos jovens e adultos na escola, estabeleceu a Base Nacional Comum Curricular (BNCC), que deverá ser seguida por essa modalidade de ensino, bem como as demais diretrizes estabelecidas pelos poderes públicos voltadas especificamente à EJA.

A BNCC foi regulamentada pela Lei no $12.796 / 2013$, que estipulou

os currículos da educação infantil, do ensino fundamental e do ensino médio devem ter base nacional comum, a ser complementada, em cada sistema de ensino e em cada estabelecimento escolar, por uma parte diversificada, exigida pelas características regionais e locais da sociedade, da cultura, da economia e dos educandos (BRASIL, 2013).

A BNCC do Ensino Médio, como no caso do curso de EJA - Ensino Médio, está organizada por áreas do conhecimento. Esse tipo de organização permite que dois ou mais componentes do currículo sejam integrados e facilitem a compreensão da realidade, descomplicando seus conteúdos, tornando-os mais significativos.

\section{EDUCAÇÃO A DISTÂNCIA NA EJA}

No Brasil, a educação a distância foi regulamentada pela LDB, sendo vista como uma modalidade educacional que promove a 
mediação pedagógica dos processos de ensino e aprendizagem mediante tecnologias da informação e comunicação, com alunos e professores desenvolvendo atividades educativas em locais e tempos diferentes, incentivando a educação permanente e permitindo a atualização e aperfeiçoamento profissional continuado.

Historicamente, as instituições de ensino ofereceram soluções para incluir alunos geograficamente distantes usando diversos meios, desde o ensino por correspondência até a transmissão via satélite, mas, apenas na década de 1990, a tecnologia possibilitou a comunicação e a interação contínua e viável entre professores e alunos.

Os sistemas de ensino, segundo o art. $8^{\circ}$ da LDB, são organizados pela União, pelos estados, pelo Distrito Federal e pelos municípios, com liberdade nos termos da lei e com a coordenação da política da educação nacional feita pela União. Em seu art. 10, a LDB estabelece as incumbências dos estados para com a educação e, entre outras, permite autorizar, reconhecer, credenciar, supervisionar e avaliar, respectivamente, os cursos das instituições de educação superior e os estabelecimentos do seu sistema de ensino. É permitido também, aos sistemas de ensino, emitir normas complementares.

Os estabelecimentos de ensino que ofertam cursos a distância na educação básica no âmbito da respectiva unidade da federação a que pertencem devem seguir as normas dos seus sistemas de ensino. Para a oferta fora da unidade da federação, devem solicitar credenciamento junto ao Ministério da Educação, em regime de colaboração e cooperação com os órgãos normativos dos sistemas de ensino envolvidos. 
O Centro Integrado de Educação Básica para Jovens e Adultos Uninter $^{38}$ oferta a EJA - Ensino Médio a distância desde 2011. O curso tem como objetivo oferecer ao aluno condições de desenvolvimento integral e atendimento de qualidade com acesso ao conhecimento, com respeito à sua faixa etária, seu nível de escolaridade, sua disponibilidade de tempo, seu ritmo de aprendizagem e sua identidade cultural. Recebendo jovens e adultos, trabalhadores, com experiência profissional ou com expectativa de (re)inserção no mercado de trabalho e jovens que evadiram a escola por motivos de caráter sociocultural, na EJA Uninter já concluíram o curso mais de 3.000 alunos.

A organização pedagógica do curso compreende todas as atividades de ensino e aprendizagem, com ênfase nas interações que ocorrem entre professores, alunos e o grupo. A interatividade a distância, no Ambiente Virtual de Aprendizagem (AVA), abre muitas possibilidades para que o receptor da mensagem possa responder e dialogar com o emissor. O AVA é um ambiente de gestão e construção integradas de informação, comunicação e aprendizagem on-line. Pode reunir diversas interfaces síncronas e assíncronas. É a sala de aula não restrita à temporalidade do espaço físico, na qual os responsáveis podem disponibilizar conteúdos e proposições de aprendizagem, podendo acompanhar o aproveitamento de cada estudante e da turma.

Os alunos têm a oportunidade de estudar, de se encontrar a qualquer hora, interagindo com os conteúdos propostos, acessando a biblioteca virtual, o fórum de discussões, tirando dúvidas e realizando avaliações. Cada aprendiz toma decisões, analisa, interpreta, observa, testa hipóteses, elabora e colabora. O professor disponibiliza o acesso a um mundo de informações, fornece conteúdo didático multimídia para estudo, objetos de aprendizagem e materiais complementares.

${ }^{38}$ Credenciado pelo Parecer CEE-PR n 56/2011 e Resolução SEED-PR n 857/2011. 
Na EJA Uninter, a integração curricular é feita por práticas educativas que permitem ao alunado uma contextualização e significação de temas atuais de grande relevância em suas vidas.

\begin{abstract}
A prática pedagógica reflexiva como pontos de partida e chegada a prática social. Caracteriza-se pela indissolubilidade entre teoria e prática, em que as dicotomias tendem a desaparecer. Com um caráter inquieto, criador e acentuado grau de consciência, a prática pedagógica tem como preocupação produzir mudanças qualitativas e, para isso, procura munir-se de um conhecimento crítico e aprofundado da realidade (SCHMIDT; RIBAS; CARVALHO, 1999, p. 23).
\end{abstract}

\title{
ESTUDO DE CASO
}

É uma metodologia de pesquisa e estudo de determinado campo, que inclui observação, entrevistas, fontes midiáticas (fotografia, gravação etc.) e anotações. Busca-se o idiossincrático, ou seja, situações incomuns, inusitadas, pouco exploradas, com a compreensão de eventos particulares. Os estudos de caso visam a retratar a realidade de maneira completa, crua, profunda e historicamente contextualizada.

Ele é composto pela apresentação de determinado caso, que deve ser interpretado de maneira contextualizada com o auxílio de diferentes fontes de pesquisa indicadas e vários pontos de vista. Podem ser apresentados em diferentes gêneros textuais, sendo o objetivo final desta prática suscitar a possibilidade de propor oportunidades de melhorias em sua realidade pessoal e na comunidade local, com o desenvolvimento de conhecimentos, habilidades, atitudes, valores e condições socioemocionais para agir diante de determinada situação. 


\section{PORTFÓLIO}

Nesta prática, a pesquisa e o estudo são aprofundados. As habilidades de leitura, escrita e oralidade são desenvolvidas a partir de temas relevantes para a vida. Desenvolvido por etapas de leitura, pesquisa, prática e produção, o portfólio apresenta a oportunidade de intercâmbio entre os alunos a partir do diálogo para uma produção compartilhada.

Do movimento da teoria à prática, as indicações de leitura auxiliam a produção de gêneros textuais que servem de oportunidade para a prática reflexiva. Revendo sua prática por meio da revisão da teoria, os estudantes podem rever também suas ações.

\section{A EJA UNINTER EM TEMPOS DE PANDEMIA}

Assim como em todo o mundo, a interrupção das atividades educativas no Brasil se fez necessária para evitar o contágio em grande escala do vírus causador da Covid-19. A pandemia modificou o cotidiano de milhões de pessoas e afetou a população não somente pelos danos à saúde, mas também a outras esferas da vida social. 0 mundo terá de enfrentar esse exército invisível com o rompimento da normalidade, modificando estruturas estáveis que caracterizavam a humanidade.

Segundo dados da Organização das Nações Unidas para a Educação, a Ciência e a Cultura (Unesco), em abril de 2020, 91,3\% da população estudantil mundial (equivalente a 1,600 milhão de estudantes) ficou impossibilitada de frequentar as aulas presenciais. Os desafios dos sistemas educacionais são imensos, mas não inéditos. Já tendo enfrentado outras epidemias, mais uma vez a educação 
continuou a sua missão, mesmo de portas fechadas. A comunidade educativa, colaborando positivamente com as autoridades sanitárias, ficou em casa.

Já estruturado a distância, o curso EJA - Ensino Médio da Uninter possibilitou a continuidade dos estudos para jovens e adultos que não poderiam mais frequentar as aulas presenciais. Com os polos de apoio presencial fechados, as atividades lá realizadas foram transferidas para a plataforma virtual. Com diversos momentos de interação, a instituição de ensino ofereceu diversas oportunidades de estudo e a participação em cursos de extensão promovidos pelo Centro Universitário Internacional Uninter, disponíveis aos alunos da EJA, oportunizou a ampliação do conhecimento.

A aprendizagem promove o desenvolvimento de novas práticas culturais quando o ser humano reflete sobre a sua experiência de vida. A formação de uma consciência, associada à qualidade das experiências de aprendizagem dos indivíduos, é capaz de transformar a forma de entender e agir no mundo. As ações interdisciplinares entre os saberes acadêmicos e a sociedade possibilitam a apropriação dos conhecimentos necessários à compreensão dos riscos ambientais e à capacidade de intervenção, que pode ser determinante para reduzi-los.

Com a crise do coronavírus, as desigualdades no mundo se ampliaram. A pobreza, a marginalização, a migração, danos ambientais e suas consequências serão apenas alguns dos legados da pandemia. Adaptações nos sistemas educativos formais para que os alunos aprendam o que é necessário fazer para ter uma vida sustentável são requisitos para a mudança de paradigma e para que se desenvolvam valores éticos ambientais. 


\section{CONSIDERAÇÕES FINAIS}

A EJA é uma modalidade da educação básica que oferece muitos desafios. Além dos já constatados, como a evasão, a atual crise sanitária e, consequentemente, da economia fará com que a EJA e a educação a distância se façam cada vez mais necessárias, como também a formação de profissionais e o aumento da oferta da EJA por instituições de ensino que atendam a essa modalidade com eficiência. Para atingir os objetivos de uma educação reparadora, equalizadora e de qualidade, a aprendizagem deve caminhar ao lado da formação dos indivíduos para a vida em sociedade.

\section{REFERÊNCIAS}

BRASIL. LEI No 9.394, de 20 de dezembro de 1996. Estabelece as diretrizes e bases da educação nacional. Disponível em <http://www.planalto.gov.br/ccivil_03/leis/19394.htm>.

BRASIL. LEI No 12.796, de 04 de abril de 2013. Altera a Lei no 9.394, de 20 de dezembro de 1996, que estabelece as diretrizes e bases da educação nacional, para dispor sobre a formação dos profissionais da educação e dar outras providências. Disponível em <http://www.planalto.gov.br/ccivil_03/_ato20112014/2013/lei/l12796.htm>.

CENTRO INTEGRADO DE EDUCAÇÃO BÁSICA PARA JOVENS E ADULTOS UNINTER. Plano de curso EJA - Ensino Médio- UNINTER. Curitiba: 2020.

CENTRO UNIVERSITÁRIO INTERNACIONAL UNINTER. ESCOLA DE EDUCAÇÃO SUPERIOR. Manual de Práticas ESE - UNINTER. Curitiba: 2020.

CNE - CONSELHO NACIONAL DE EDUCAÇÃO. Parecer 11/2000, de 10 de maio de 2000. Diretrizes Curriculares Nacionais para a Educação de Jovens e Adultos.

CONFERÊNCIA INTERNACIONAL SOBRE A EDUCAÇÃO DE ADULTOS (V: 1997: Hamburgo, Alemanha): Declaração de Hamburgo: agenda para o futuro. Brasília: SESI/UNESCO, 1999.

GIMENO SACRISTÁN, J. Consciência e acção sobre a prática como libertação profissional dos professores. In: NÓVOA, A. Profissão Professor. Porto: Porto Ed., 1995. p.63-92.SCHMIDT, L. M., RIBAS, M. H.; CARVALHO, M. A. de. A prática pedagógica como fonte de conhecimento. In: ALONSO, M. O Trabalho Docente: teoria e prática. São Paulo: Pioneira, 1999. p. 19-33. 


\title{
CAPÍTULO 09 - PANDEMIA E SISTEMAS EDUCACIONAIS: UM OLHAR SOBRE A SAÚDE DO PROFESSOR
}

\author{
THAISA MARIA NADAL 39 \\ THEODORO LUTEMBERG DE SOUZA 40
}

\section{INTRODUÇÃO}

A pandemia de Covid-19 causou um choque sem precedentes nos sistemas educacionais, perturbando a vida de quase 1,6 bilhão de alunos em mais de 190 países em todos os continentes. O fechamento de escolas e outros locais de aprendizagem afetou 94\% da população instruída do mundo e até 99\% em países de baixa e média-baixa renda. A crise agrava as disparidades educacionais existentes, com um grande número de crianças, jovens e adultos entre os mais vulneráveis (habitantes de áreas pobres ou rurais, meninas, refugiados, pessoas com deficiência e deslocados internos), com o risco de não regressarem à escola.

O tempo de aprendizado perdido não só prejudica a geração atual, mas pode acabar com décadas de progresso, especialmente em termos de acesso de meninas e mulheres jovens à educação e sua persistência na escola. Cerca de 23,8 milhões de crianças e jovens (da pré-escola ao ensino superior) também podem abandonar a escola ou ter o acesso à educação negado no próximo ano, devido ao impacto econômico da pandemia.

\footnotetext{
39 Mestra em Gestão Ambiental. Professora no Centro Universitário Internacional Uninter.

${ }^{40}$ Especialista em Geografia. Professor no Centro Universitário Internacional Uninter.
} 
Da mesma forma, o choque nos sistemas educacionais teve, e continuará a ter, efeitos significativos além da esfera educacional. 0 fechamento de escolas dificulta a prestação de serviços básicos às crianças e às populações, incluindo o acesso a alimentos nutritivos, além de impedir muitos pais de trabalhar normalmente. À medida que as restrições orçamentárias pioram e a ajuda ao desenvolvimento é ameaçada, a educação também pode enfrentar graves problemas de financiamento, o que agravaria as dificuldades já existentes a esse respeito antes da epidemia.

Ao mesmo tempo, a crise estimulou a inovação no setor educacional. Assistimos ao surgimento de iniciativas inovadoras, que permitiram a continuação de atividades de educação e formação - na rádio, na televisão ou na forma de kits educativos para o lar. As fórmulas de educação a distância foram desenvolvidas graças à rápida intervenção de Estados e parceiros em todo o mundo determinados a garantir a continuidade pedagógica, em particular, a Coalizão Mundial para a Educação estabelecida pela Organização das Nações Unidas para a Educação, a Ciência e a Cultura (Unesco).

A crise também nos lembrou do papel crucial dos professores e da responsabilidade dos Estados e outros parceiros em garantir a saúde e o bem-estar do pessoal da educação. Mas essas inovações também deixaram claro que as perspectivas promissoras abertas à educação e as rápidas mudanças nos métodos de ensino só poderão ser sustentadas se ninguém for deixado para trás. Isso vale para crianças e jovens com poucos recursos ou cujo ambiente oferece pouco acesso à educação, como também se aplica a professores que precisam ser mais bem treinados e apoiados em novas formas de ensino. Por fim, isso também se aplica ao mundo da educação em geral, incluindo as comunidades locais, das quais depende a continuação das atividades educativas durante a crise e cujo papel será essencial para reconstruir melhor. 
A crise de saúde e a revolta sem precedentes dos sistemas educacionais que ela causou estão longe de acabar. Em nada menos que cem países, ainda não se sabe quando as escolas reabrirão e estados, sindicatos, pais e crianças em todo o mundo estão se perguntando quando e como o ano letivo ocorrerá. Alguns países começaram a se preparar para a reabertura de escolas em seu território, seja por níveis de classe, priorizando aulas que preparam para um exame, seja por regiões com poucos casos de contaminação. No entanto, dadas a continuidade e a virulência da epidemia, a maioria dos países ainda não havia definido uma data de reabertura até o final de 2020. Essa decisão terá enormes consequências sociais e econômicas e um impacto duradouro sobre professores, crianças e jovens, seus pais - especialmente mulheres - e a sociedade como um todo.

\section{A PANDEMIA NO MUNDO}

Antes da pandemia, o mundo já enfrentava grandes dificuldades em fazer da educação um direito humano fundamental, uma realidade para todos. Apesar da escolaridade em muitos países, um número considerável de crianças (mais de 250 milhões) não frequentava a escola e quase 800 milhões de adultos eram analfabetos. Além disso, para as crianças em idade escolar, o anúncio estava longe de ser garantido. Estima-se que cerca de 387 milhões de crianças no mundo na idade escolar primária (56\%) não dominam as habilidades básicas da leitura. (CUNHA, SILVA, SILVA, 2020).

A pandemia de Covid-19 causou a maior interrupção nos sistemas educacionais da história, afetando quase todos os alunos e professores do mundo, em creches, escolas primárias, faculdades e escolas de Ensino Médio, instituições de ensino e formação técnica e profissional, universidades, centros de aprendizagem de adultos e instituições profissionais. Em meados de abril de 2020, 94\% dos 
estudantes em todo o mundo foram afetados pela pandemia, o que corresponde a 1,58 bilhão de crianças e jovens na escola do préprimário ao terciário em 200 países. (CUNHA, SILVA, SILVA, 2020).

A capacidade de lidar com o fechamento de escolas tem sido mais ou menos grande, dependendo do nível de desenvolvimento, com grandes disparidades; por exemplo, no segundo trimestre de 2020, 86\% dos alunos do Ensino Fundamental abandonaram a escola completamente nos países com baixos índices de desenvolvimento humano, em comparação a apenas $20 \%$ em países com índices de desenvolvimento humano muito elevados. (CUNHA, SILVA, SILVA, 2020).

Nos sistemas educacionais mais sensíveis, a interrupção do ano letivo terá um efeito particularmente prejudicial sobre os alunos mais vulneráveis, aqueles cujas casas não proporcionam um ambiente favorável para uma aprendizagem mais profunda. Sua presença em casa também pode criar dificuldades financeiras para os pais, que têm de encontrar soluções para seus cuidados e cuidar das refeições fornecidas pela escola.

Há agora um medo de que, se essas crianças não conseguirem a ajuda de que precisam, elas nunca mais voltarão para a escola. Isso só exacerbaria as disparidades existentes e arriscaria minar o progresso na implementação da meta de desenvolvimento sustentável. No entanto, a desorganização do ensino produzirá muitos efeitos além da esfera educacional. Devido ao fechamento de escolas e outros locais educacionais, os serviços de ensinamento não são mais prestados a crianças e populações.

Conforme Cunha, Silva, Silva, (2020), a interrupção da distribuição da merenda escolar e dos serviços de saúde e nutrição nos primeiros meses da pandemia afetou 370 milhões de crianças em 195 países, exacerbando a fome e as deficiências nutricionais entre as mais desfavorecidas. Alguns países, no entanto, foram capazes de se adaptar e continuar seus níveis de alimentação escolar. A crise também 
afetou os serviços de saúde e psicossociais, com as escolas sendo locais de prevenção, diagnóstico e conselhos. Grupos vulneráveis não têm mais acesso a alguns serviços básicos e esquemas de proteção social.

O fechamento de escolas igualmente impediu que muitos pais trabalhassem normalmente, com a permanência de seus filhos na creche ou na escola. Ainda conforme Cunha, Silva, Silva, (2020), em países como Alemanha, Estados Unidos, França, Itália e Reino Unido, $60 \%$ dos pais não encontraram nenhuma maneira em manter seus filhos. Nesse sentido, de acordo com um estudo recente, as mulheres assumem a maior parte do tempo extra que precisa ser gasto com crianças e tarefas domésticas, situação que, combinada com a atual crise econômica, provavelmente contribuirá para ampliar a lacuna nas remunerações, o que agravará ainda mais as desigualdades de gênero.

À medida que os pais perdem sua renda, enfrentam escolhas difíceis; as taxas de escolaridade das meninas podem diminuir, enquanto o recrutamento e a exploração de crianças aumentarão. Como se espera que 71 a 100 milhões de pessoas caiam em extrema pobreza como resultado da pandemia, será necessário monitorar as taxas de abandono escolar e olhar para os custos de oportunidade de orientar a escolha dos pais para financiar ou não a educação de seus filhos. (CUNHA, SILVA, SILVA, 2020).

Diante de uma crise de saúde que causou sérios choques socioeconômicos, os sistemas educacionais em todo o mundo reagiram rapidamente para se adaptar. Os Estados se movimentaram às pressas para garantir a continuidade da educação e, a fim de proteger a saúde dos alunos e professores, fecharam escolas e outros locais de aprendizagem. No entanto, as disparidades na educação durante o fechamento das escolas provavelmente levarão a desigualdades em longo prazo.

Garantir a continuidade da educação durante o fechamento das escolas tornou-se a prioridade dos Estados em todo o mundo. Com o 
mundo digital em alta, isso tem forçado os professores a entregar seus cursos pela internet. Nessa direção, os países têm favorecido uma variedade de métodos de educação a distância, dependendo dos níveis de classe, com diferenças regionais. Em áreas onde o acesso à internet é limitado, os Estados têm feito maior uso do ensino a distância tradicional, muitas vezes combinando televisão e radiodifusão com programas educacionais e distribuição de mídia impressa.

Poucos países medem o número de estudantes que realmente recebem educação a distância e como a usam. Entretanto, as estimativas mostram diferenças: em países de alta renda, cerca de $80 \%$ a $85 \%$ dos estudantes recebem educação a distância, em comparação com menos de $50 \%$ em países de baixa renda. Essa lacuna se deve principalmente à divisão digital, com as famílias desfavorecidas tendo pouco acesso a instalações coletivas, como eletricidade e infraestrutura de informática, além de alunos, pais e professores que têm pouco controle sobre ferramentas digitais.(CUNHA, SILVA, SILVA, 2020).

Desde o início da pandemia, os professores foram imediatamente encarregados de organizar atividades de ensino a distância, muitas vezes sem orientação ou treinamento e sem recursos suficientes. Em muitos casos, a formação profissional docente tem sido realizada online ou por aplicativos de telefone ou vídeo, mas professores em áreas marginalizadas às vezes não recebem nenhum apoio.

Reuniões de classe em plataformas on-line e aplicativos de mensagens tornaram-se ferramentas e permitiram que os professores desenvolvessem novas formas de comunicação comunitária com seus alunos e colegas. Contudo, a maioria deles, em todo o mundo, não estava preparada para garantir a continuidade da educação e se adaptar a novas formas de ensino. Mesmo em países com conectividade e infraestrutura adequadas à internet, muitos professores não possuíam habilidades básicas de computador, sendo provável que eles lutaram para garantir seu próprio desenvolvimento 
profissional e, mais importante, para contribuir para uma educação a distância de qualidade. Portanto, a crise de saúde revelou que a formação inicial e continuada de professores precisava ser redesenhada para abordar novas formas de educação.

De outro lado, professores encarregados de salas presenciais para crianças trabalhadores essenciais e crianças vulneráveis tiveram sua saúde física posta em risco. Além do medo de serem expostos ao vírus, eles se depararam com um aumento da carga de trabalho e das responsabilidades familiares. Esse é particularmente o caso dos professores que continuaram a ensinar enquanto prestam a maior parte dos cuidados familiares.

Alguns países incorporaram apoio psicológico aos seus planos, manuais e guias para professores e associações locais para lidar com a crise e organizações não governamentais se mobilizaram para fornecer apoio adicional. Além disso, os professores precisam ser ajudados a suprir as necessidades psicológicas de seus alunos. Sem esse apoio, a pressão pode acarretar caos emocional e físico, podendo levar alguns a abandonar seus empregos, o que pode minar os esforços para construir a resiliência escolar.

O efeito da pandemia sobre o emprego e os salários não tem sido o mesmo em todos os lugares. De acordo com dados recentes, apenas uma minoria de países parou de pagar professores estatutários. No entanto, as licenças não pagas e os pagamentos atrasados aumentaram. No setor público, professores com contrato temporário foram particularmente afetados, com seus contratos não sendo renovados (PEREIRA, SANTOS, MANENTI, 2020).

Em países de baixa renda, onde os pais pararam de pagar as taxas escolares e o ensino on-line tem sido impossível, os professores perderam seus meios de subsistência. Em uma pesquisa sobre educação internacional com 93 sindicatos de professores em 67 países, quase dois terços dos entrevistados relataram que os funcionários da educação em escolas privadas sofreram muito como resultado da crise, 
com funcionários temporários e de apoio sendo os mais afetados. Se as escolas privadas fechassem permanentemente, hoje ou amanhã, a educação pública seria forçada a acomodar um grande número de alunos adicionais (CUNHA, SILVA, SILVA, 2020).

O não pagamento de salários não afeta apenas o bem-estar dos professores, suas famílias e comunidades, mas também dificulta o bom funcionamento das escolas. Em curto prazo, muitos docentes podem precisar de outras fontes de renda e deixar de fornecer aos alunos educação a distância. Em longo prazo, as escolas podem enfrentar a escassez de professores como resultado das partidas. A crise nos lembra dos professores e que é responsabilidade dos Estados e parceiros-chave garantir a saúde e o bem-estar dos funcionários da educação.

Para garantir uma educação justa e inclusiva em sala de aula e em outros lugares, professores e comunidades precisam estar mais bem preparados e apoiados. Só a tecnologia não pode garantir a aquisição de conhecimento. Embora seja importante formar professores em ferramentas digitais, é ainda mais importante garantir que eles tenham habilidades pedagógicas que Ihes permitam se adaptar aos níveis e aplicar a aprendizagem acelerada e estratégias de ensino diferenciadas que provavelmente serão implementadas no início do ano letivo. Isso porque soluções digitais exigem conteúdo relevante, boas práticas de ensino e um ambiente de aprendizagem de apoio.

A saúde física e emocional dos profissionais da educação também deve receber atenção redobrada. Para que todo o aparato digital tenha sucesso, é importante que o professor esteja bem.

\section{A PANDEMIA NO BRASIL}

No final de 2019, o mundo soube do surgimento de um vírus altamente transmissível, com a cidade de Wuhan, na região central da China, sendo apontada como o local de surgimento do coronavírus, 
causador da Covid-19, que rapidamente se disseminou pelo mundo (OMS, 2020). Logo a Organização Mundial da Saúde (OMS) deu o alerta para que os países do mundo se preparassem, criando protocolos de segurança sanitários para o enfrentamento da pandemia. A preocupação dos órgãos de saúde era muito grande e, como se pôde observar pelas manchetes de jornais, medidas rigorosas, como isolamento das pessoas e aplicação de períodos de quarentena, foram adotadas, na tentativa de conter o avanço do vírus e para proteger as pessoas.

A confirmação do primeiro caso no Brasil ocorreu em 26 de fevereiro de 2020 e logo se adotaram medidas para conter a propagação do coronavírus em território nacional. Por se tratar de um país de dimensões continentais, a disseminação acabou ocorrendo de forma desigual, em ritmo diferente entre os estados, o que os levou a protocolos diferentes e não coordenados para o enfrentamento da crise gerada pela pandemia.

Com a pandemia, os gestores públicos passaram a orientar a população sobre os protocolos de saúde e a interrupção das atividades econômicas se fez necessária para diminuir o ritmo de contaminação da população, para evitar a sobrecarga do sistema de saúde e tentar diminuir o número de mortes. Mesmo assim, o Brasil ocupa o segundo lugar em número de óbitos causados pela Covid-19, segundo informações do Ministério da Saúde e da OMS.

Nesse contexto, o governo, para diminuir a transmissão do vírus, determinou que somente as atividades consideradas essenciais deveriam permanecer abertas; com isso, pré-escolas, escolas, colégios, faculdades e universidades, tanto públicos quanto privados, foram fechadas. Contudo, a educação é fundamental para a sociedade e mesmo, com o isolamento social, houve a necessidade de criar mecanismos para levar os conteúdos para crianças e jovens que estavam em isolamento. 
O Conselho Nacional de Educação se posicionou por meio do Parecer no 5/2020 sobre as aulas ofertadas de forma remota, que poderiam, sim, ser computadas para atender à obrigatoriedade das horas letivas por lei.

Com a suspensão dos calendários letivos nova tarefa se anuncia para professoras e professores: como garantir o direito à educação em meio a pandemia? Se no início do isolamento existia a esperança de um rápido retorno, com o passar dos dias foi se percebendo que havia a necessidade de adoção de providências (PEREIRA, SANTOS, MANENTI, 2020).

Vários governos estaduais e municipais implantaram o ensino remoto, utilizando recursos disponibilizados na internet, redes sociais e canais de televisão para levar aos alunos os conteúdos e aulas ministradas por professores remotamente. $\mathrm{O}$ uso de ferramentas como - Google Classroom, Meet, entre outras, possibilitou essa entrega, mas isso foi realizado às pressas, sem um planejamento ou capacitação dos professores, que muitas vezes viram-se tendo de aprender a usar ferramentas e tecnologias da informação e comunicação com que não estavam acostumados ou a que não tinham acesso.

As mudanças que ocorreram com o uso das novas tecnologias modificaram a forma de realização do trabalho docente, gerando apreensão e estresse para muitos profissionais da educação, pela obrigação de atender às demandas que surgiram com o ensino remoto adotado em vários estados do Brasil.

Cabe ressaltar que não é educação a distância, pois, para essa modalidade de ensino, a criança e o jovem ainda não possuem a maturidade para compreender que a construção do saber depende de sua organização e disciplina e que a organização dos conteúdos e das disciplinas é proposta pensando na autoaprendizagem. Os conteúdos do currículo da educação básica necessitam da mediação do professor, que deve estar presente nesse processo de ensino-aprendizagem para contribuir com o educando na sua apropriação dos saberes. Nota-se, nesse ponto, o tamanho da dificuldade de professores em atender às 
necessidades educacionais dos alunos, que, muitas vezes não têm condições técnicas e econômicas de acompanhar as aulas.

Uma situação que ficou exposta com a pandemia é o tamanho da desigualdade entre as pessoas e regiões do Brasil. Alguns estados e municípios conseguiram implantar o ensino remoto, mesmo com falhas de organização, enquanto outros não conseguiram disponibilizar as aulas remotas, seja por falta de tecnologia, seja por falta de recursos financeiros. Essa situação também ocorreu em grandes centros urbanos, onde famílias não tinham condições de possibilitar aos seus filhos o acesso ou acompanhamento dos conteúdos das aulas ofertadas pela internet, tendo de recorrer ao material impresso ofertado pelas escolas.

\section{PARANÁ}

Com a Resolução Seed no 1.016/2020, o estado do Paraná estabeleceu em caráter emergencial a forma como se daria o ensino remoto, a saber:

Resolução Seed no 1.016 - 03/04/2020 Regime especial aulas não presenciais Publicado no Diário Oficial no. 10665 de 8 de Abril de 2020

Súmula: Estabelece em regime especial as atividades escolares na forma de aulas não presenciais, em decorrência da pandemia causada pelo COVID-19. [Republicação - versão final] O Secretário de Estado da Educação e do Esporte, no uso das atribuições que Ihe são conferidas pela Lei n.0 19.848, de 3 de maio de 2019, considerando a Lei Federal n. ${ }^{\circ} 13.979$, de 6 de fevereiro de 2020, a Portaria n.o 356, de 11 de março de 2020, o Decreto Estadual n. ${ }^{0} 4.320$, de 20 de março de 2020, e a Deliberação do Conselho Estadual de Educação n. ${ }^{\circ} 01$, de 31 de março de 2020, RESOLVE:

Art. 1.0 Estabelecer no âmbito da Secretaria de Estado da Educação e do Esporte - SEED, em caráter excepcional, o regime especial para a oferta de atividades escolares na forma de aulas não presenciais, em conformidade com o disposto na Deliberação n.o 01/2020 - CEE/PR, exarada em decorrência da pandemia causada pelo COVID-19. (Diário Oficial nº 10665 de 8 de Abril de 2020). 
Com a adoção do ensino remoto, também se fez necessário a capacitação dos professores para a utilização das plataformas tecnológicas escolhidas. Além disso, os alunos tinham muita resistência em aceitar o ensino ofertado de forma remota, por não se identificarem com os professores que ministravam as aulas e mesmo pelo formato remoto, que para eles não atendiam às suas necessidades, sentindose isolados. Nesse contexto, os docentes viram-se diante da realidade de atender a alunos em vários canais de comunicação - Meet, e-mail, WhatsApp, Facebook, Instagram, entre outros -, realizar gravação de aulas, produzir e corrigir atividades nos mais variados horários, pois muitos alunos realizam suas atividades à noite quando os pais chegam em casa ou por outros motivos.

Os desafios de compreender as novas tecnologias usadas, somados ao aumento da sobrecarga de trabalho originada pelas atividades extras ao trabalho docente, começaram a afetar a qualidade de vida e a saúde dos educadores durante a pandemia, além de a situação também ter trazido angústia aos profissionais da educação. Ainda, professores, pedagogos e equipes diretivas passaram a pensar em estratégias para fazer o resgate dos alunos que estavam desistindo de realizar as tarefas e atividades propostas, tendo ocorrido aumento do trabalho e cobrança para que se diminuísse o número de desistentes. Essas ações eram necessárias, pois os alunos precisam ser resgatados, mas, ao mesmo tempo, exigiram um esforço maior dos educadores.

Ademais, a sociedade, por não compreender como funciona o trabalho pedagógico, passou a questionar a razão de as escolas estarem fechadas. As famílias precisavam que elas retornassem às atividades para poder ter um lugar seguro para deixar seus filhos enquanto estivessem trabalhando. De fato, já há algum tempo, a escola é vista como um espaço para os alunos ficarem seguros e de socialização e interação que, com a pandemia, tem deixado crianças e jovens sem esse vínculo afetivo. 
O trabalho do docente na pandemia não seguiu uma rotina, com mudanças significativas na sua organização e alteração de sua jornada de trabalho para atender a alunos e demandas burocráticas impostas pelo governo; para não haver cobrança, o atendimento dos alunos passou a ser realizado em vários horários, o que trouxe prejuízo para a saúde dos professores, devido à mudança nos seus horários de sono e de alimentação, gerando situações de estresse, depressão, angústia, entre outros problemas relacionados ao isolamento social.

Compreendendo o cenário que estamos vivendo, com medidas extremas sendo tomadas pelos gestores públicos na tentativa de diminuir a contaminação pelo coronavírus, para proteger o maior número de vidas possíveis e evitar o colapso do sistema de saúde, foram propostas aos professores, tanto da rede pública quanto particular de ensino, aulas no formato remoto, mas ainda não se tem uma avaliação de como essa modalidade de ensino afetou os alunos, que sentiram a falta do convívio com os amigos e os professores, sem uma rotina de estudos definida. Docentes e discentes precisaram adaptar-se a uma nova realidade de interação, composta por ferramentas do Google Meet, e-mails, murais ${ }^{41}$, redes sociais, além das tarefas e atividades on-line.

\section{SAÚDE DO PROFESSOR NA PANDEMIA}

O início do ano de 2020 foi marcado pelo surgimento de um vírus que modificou a forma de a sociedade se organizar, alterando as relações pessoais e impondo o isolamento e distanciamento social. Nesse contexto, em que as pessoas passaram a temer o coronavírus,

\footnotetext{
${ }^{41}$ Os murais da sala de Aula Virtual do Google Classrom têm a função de ser um espaço de avisos e interação com os alunos. Como por exemplo https://educador.brasilescola.uol.com.br/estrategias-ensino/como-usar-o-googleclassroom.htm
} 
que ainda não tem um tratamento efetivo, surgiu a necessidade de adaptação das pessoas a novas rotinas de trabalho, com o uso de equipamentos de proteção individual, como máscaras, para evitar o contágio. Além disso, a forma de trabalhar mudou, com as novas tecnologias da comunicação proporcionando uma mudança de paradigma que se pensava para o futuro e que foi realizada na urgência devido à pandemia, a fim de manter as atividades econômicas e a renda das pessoas diante de um cenário de forte recessão econômica e de desemprego.

Entre as atividades que precisaram se adaptar a essa nova realidade, a área da educação precisou se adequar ao uso de ferramentas para as quais a maioria das instituições públicas de ensino não estavam preparadas. Aulas remotas, plataformas virtuais de ensino, diferentes redes de interação passaram a fazer parte da rotina dos professores, que em muitos casos ultrapassaram a sua carga horária de trabalho para poder atender aos alunos e às demandas como produção e correção de atividades, preparação de aulas para os alunos remotos e atendimento aos alunos que encaminhavam atividades impressas.

Como o profissional da educação estava em casa, uma parcela significativa da população que não compreende o trabalho do professor não entendia que ele estava, sim, trabalhando, fazendo o atendimento dos alunos, e começaram a questionar por que as aulas não retornavam, tendo em vista que tantas outras atividades voltaram a funcionar. Essa cobrança, acrescida da sobrecarga de trabalho, trouxe reflexos para a saúde do professor, que em tempos de pandemia, com o isolamento e o estresse das inúmeras atividades a ser realizadas, começou a sentir os efeitos físicos e mentais da mudança da rotina diária; no caso das mulheres, isso somou-se ao acúmulo das atividades da casa e ao atendimento dos filhos.

Assim, este trabalho busca compreender como ficou a saúde do trabalhador da educação e os efeitos que a pandemia trouxe para a 
sua qualidade vida, numa abordagem de estudos realizados e apresentados em artigos publicados que discorrem sobre o tema.

\section{EFEITOS DA COVID-19 NO TRABALHO DOCENTE}

Ao longo de 2020, entre as muitas preocupações e ações que se fizeram necessárias por conta do isolamento social, como lockdown e medidas restritivas, surgiu a necessidade de criar estratégias para o ensino remoto, como vimos anteriormente, mas estudos apontam que a saúde dos professores ficou muito prejudicada.

Antes mesmo da pandemia, estudos realizados apontavam problemas relacionados à saúde dos profissionais da educação, como estresse, transtornos mentais e alergias em decorrência do uso de giz. No período pandêmico, a ansiedade causada pela mudança na rotina do trabalho, somada à angústia por terem de se adaptar a uma realidade a que não estavam preparados, levou muitos professores a adoecer:

Muitas vezes, por não conseguir atingir os objetivos propostos pela instituição, e devido às diversas pressões relacionadas ao manuseio das tecnologias, gravações de aulas, os docentes acabam adoecendo. (SILVA, eT aL, 2020, p.4)

Desafios relacionados a mudanças no trabalho docente, com a adoção de novas estratégias por parte de gestores, causaram sofrimento para os educadores mesmo antes da pandemia. Segundo Moreira e Rodrigues (2018, p.239),

alguns transtornos e doenças relacionados ao trabalho têm sido característicos do trabalho atual, marcado por novos modelos de gestão flexíveis, que solicitam mudanças e pressões constantes na atuação dos profissionais. 
Relatos de professores de escolas particulares e públicas indicam a dificuldade de adaptação ao modelo de ensino remoto, seja por conta do uso de tecnologia para a qual não receberam formação, seja por falta de equipamentos para realizar as atividades previstas, caso de professores que precisaram, mesmo com o decreto de isolamento, ir até o estabelecimento de ensino por não possuírem computador ou notebook e não terem condições de adquirir tais equipamentos.

Outro fator foi a baixa adesão dos alunos às aulas por Meet nas escolas públicas, com o professor organizando sua aula e o aluno não participando.

Essas situações, citadas ao longo do ano, levaram a alterações de humor, dificuldade para dormir, irritação, além da sensação de impotência e até mesmo de incompetência por não dominar as novas tecnologias, lembrando que a realidade das escolas públicas do Brasil é justamente a falta de investimento em novas tecnologias que contribuam para o trabalho docente, o que nos leva a vários questionamentos, conforme Cunha et al (2020, p. 32.) apontam:

[...] as primeiras indagações a serem feitas são:

i) Como fica a situação daqueles estudantes que não possuem acesso à internet, nem conseguem ir periodicamente à escola retirar tais materiais, principalmente por falta do transporte escolar?

ii) E aqueles que, mesmo tendo o acesso às aulas e atividades, não conseguem desenvolvê-las por falta de orientação/acompanhamento em suas casas?

iii) Considerando as diversas estruturas e níveis de escolaridade

das famílias brasileiras, elas terão condições de fazer o planejamento de estudos, cumprir as atividades pedagógicas e mediar o processo educativo dos alunos, conforme dispõe o CNE?

iv) Como fica, ainda, a situação daqueles estudantes que mesmo tendo direito aos dados de internet, patrocinados pelo governo, não

possuem os equipamentos tecnológicos para ter acesso às aulas?

v) O professor tem condições de desenvolver adequadamente o processo didático-pedagógico pelas tecnologias digitais utilizadas? 
vi) Será que ao mediador, em casa, caberá apenas as funções de acompanhar e orientar o aluno na organização de sua rotina diária

de estudos, ou a ele também caberá desenvolver um trabalho pedagógico com vistas à aprendizagem?

vii) Em suma, esse projeto educacional garante a qualidade e o direito e/ou a igualdade de acesso à educação para todos os estudantes?

A despeito dos questionamentos relacionados à implantação do ensino remoto, o que não é observado é como fica a qualidade de vida dos professores nessas condições de trabalho, com a necessidade de adaptar uma casa onde muitas vezes não há espaço para realizar as atividades propostas, como videoaulas; para as mulheres, ainda se deve considerar a dupla jornada a que é submetida, pois em muitos casos precisa atender aos filhos, cuidar da casa, do marido, visto que todos estão em isolamento, confinados em casa.

Os governos se preocuparam com a urgência de ofertar o ensino remoto para atender aos discentes nesse período de isolamento social, mas não houve um diálogo com os profissionais da educação que estão diretamente envolvidos nesse processo e que poderiam contribuir para criar estratégias para atender realmente às necessidades educacionais desses alunos que estavam em isolamento social. Em vez de consultar os educadores, criou-se uma oferta de aulas remotas extremamente desgastante, tanto para alunos quanto para professores.

\section{CONSIDERAÇÕES FINAIS}

O choque na educação causado pela crise da Covid-19 é sem precedentes. Ela atrasou o atingimento das metas estabelecidas pela comunidade internacional nessa área e afetou desproporcionalmente os mais pobres e vulneráveis. Por outro lado, as partes interessadas mostraram resiliência e estabeleceram as bases para a recuperação.

O risco é que a situação se deteriore ainda mais, em um ciclo de feedback negativo em que a perda de conquistas educacionais e a 
exclusão aumentariam ainda mais. No entanto, qualquer dinâmica negativa, como a do trabalho na deterioração da situação socioeconômica, é a imagem invertida de uma dinâmica positiva, que pode levar ao futuro que queremos, ou seja, uma educação inclusiva que desbloqueie o potencial dos indivíduos e alcance o atendimento coletivo em todas as áreas da vida, por meio de investimentos em sistemas de educação.

A determinação está lá e os recursos ainda estão inexplorados; vamos usá-los não só para reviver a educação, mas também para satisfazer as aspirações fundamentais que a sustentam. Cabe aos Estados e à comunidade internacional permanecer fiéis aos seus princípios e realizar reformas, para que crianças e jovens retornem ao futuro prometido a eles e todos os atores da educação encontrem o lugar que lhes convém nesse negócio.

\section{REFERÊNCIAS}

BRASIL. Ministério da Educação.

http://portal.mec.gov.br/index.php?option=com_docman\&view=download\&alias $=1$ 45011-pcp005-20\&category_slug=marco-2020-pdf\&Itemid=30192, 2020.

CUNHA, Leonardo Ferreira Farias da, SILVA, Alcineia de Souza, SILVA, Aurênio Pereira da. $O$ ensino remoto no brasil em tempos de pandemia: diálogos acerca da qualidade e do direito e acesso à educação. Revista Com Censo, V. 7 • N. 3 ago, 2020. Disponível em: periodicos.se.df.gov.br/index.php/comcenso/article/view/924 - Acesso em 22fev. 2021.

MOREIRA; Daniela Zanoni e Rodrigues, Maria Beatriz. Saúde mental e trabalho docente. Estudos de Psicologia, 23(3), julho a setembro de 2018, 236-247. Disponível em: http://pepsic.bvsalud.org/pdf/epsic/v23n3/a04v23n3.pdf - Acessado em: 22/02/2021.

ORGANIZAÇÃO MUNDIAL DA SAÚDE - OMS https://www.who.int/eportuguese/countries/bra/pt/ 2020.

PEREIRA, Hortência Pessoa; SANTOS, Fábio Viana, MANENTI, Mariana Aguiar. Saúde Mental de Docentes em Tempos de Pandemia:

Os Impactos das Atividades Remotas. Boletim de Conjuntura (BOCA) ano II, vol. 3, n. 9, Boa Vista, 2020. Disponível em: https://revista.ufrr.br/boca/article/download/Pereiraetal/3074\# : :text=Com\%20a $\% 20$ suspens $\%$ C3\%A30\%20dos $\% 20$ calend $\%$ C3\%A1rios,educa $\%$ C3\%A7\%C3\%A30 \%20em\%20meio\%20a\%20pandemia\%3F\&text=n\%C3\%A30\%20presenciais\%20pa ra\%20fins\%20de,Pandemia\%20da\%20COVID\%2D19\%E2\%80\%9D - Acesso em 22 fev. 2021.

Resolução Seed no 1.016 - 03/04/2020. Publicado no Diário Oficial no. 10665 de 8 de Abril de 2020. Disponível em: https://crianca.mppr.mp.br/arquivos/File/legis/covid19/edu/resolucao_n1016_2020 
gs_seed_pr_regime_especial_aulas_nao_presenciais_covid19.pdf_ Acesso em $22 \mathrm{fev} .2021$.

SILVA, Andrey Ferreira et al. Saúde mental de docentes universitários em tempos de pandemia. Physis: Revista de Saúde Coletiva, Rio de Janeiro, v. 30(2), e300216, 2020. Disponível em: https://www.scielo.br/pdf/physis/v30n2/01037331-physis-30-02-e300216.pdf - Acesso em 22fev. 2021. 


\title{
CAPÍTULO 10 - A PANDEMIA DO NOVO CORONAVÍRUS: IMPACTOS NO TRABALHO DOCENTE E NA APRENDIZAGEM DOS ALUNOS
}

\author{
MARIA ENEIDA FANTIN42 \\ THEODORO LUTEMBERG DE SOUZA43 \\ RENATA ADRIANA GARBOSSA SILVA44
}

O ano de 2020 mostrou-se totalmente atípico, em razão da infecção originada pelo novo coronavírus, causador da Covid-19 nos seres humanos, o que levou a Organização Mundial da Saúde (OMS) a declarar que a disseminação comunitária em todos os continentes a caracterizava como pandemia. Várias foram as recomendações do Ministério da Saúde declarando Emergência em Saúde Pública de Importância Nacional para conter o avanço, estando, entre elas, o isolamento e distanciamento social, o que ocasionou por parte de estados e municípios decretos e outros instrumentos legais e normativos com a suspensão das atividades escolares em todos os

\footnotetext{
42 Licenciada e bacharela em Geografia pela UFPR (1987). Mestra em Tecnologia pela UTFPR (2003). Graduada em Pedagogia pelo Centro Universitário Internacional Uninter (2017). Professora na Área de Geociências no Centro Universitário Internacional Uninter.

43 Graduado em Geografia (2001) e em Estudos Sociais (1998) pela Faculdades Integradas Espírita. Atualmente, é professor no Colégio Estadual João Paulo II e no Centro Universitário Internacional Uninter. Tem experiência na área de geografia, com ênfase em geografia humana.

44 Bacharela e licenciada em Geografia pela Universidade Estadual do Oeste do Paraná (2000). Mestra em Geologia pela UFPR (2003). Doutora em Geografia: Produção do Espaço e da Cultura pela UFPR (2019). Licenciada em Pedagogia pelo Centro Universitário Internacional Uninter (2020). Possui experiência no Ensino Fundamental e Médio. É professora do ensino superior desde 2003. Atualmente, é coordenadora da Área de Geociências do Centro Universitário Internacional Uninter.
} 
níveis de ensino. Sobre essas normativas, no que tange às atividades educacionais formais, é que se pretende discorrer.

\section{DETERMINAÇÕES DO MEC SOBRE OS PROCEDIMENTOS (AULAS) NA EDUCAÇÃO BÁSICA EM 2020}

A primeira ação normativa do Ministério da Educação (MEC) relativa à pandemia da Covid-19 foi a publicação da Portaria no 343, de 17 de março de 2020, voltada para as instituições de educação superior integrantes do sistema federal de ensino, se manifestando sobre a substituição das aulas presenciais por aulas em meios digitais, enquanto durasse a referida pandemia. Como se sabia do possível avanço dos casos, essa portaria foi alterada, recebendo ajustes e acréscimos por meio de outras duas portarias, quais sejam: a Portaria no 345, de 19 de março de 2020, e a Portaria no 356, de 20 de março de 2020. A primeira trouxe em seu $\S 3^{\circ}$ que ficava vedada a aplicação da substituição de que trata o caput às práticas profissionais de estágios e de laboratório, enquanto a segunda dispôs "sobre a regulamentação e operacionalização do disposto na Lei no 13.979 , de 6 de fevereiro de 2020, que estabelece as medidas para enfrentamento da emergência de saúde pública de importância internacional decorrente do coronavírus (COVID-19)".

Um dia após a publicação da Portaria no 345, de 19 de março de 2020, O Conselho Nacional de Educação (CNE) manifestou a necessidade de reorganizar as atividades acadêmicas, devido às ações preventivas à propagação da Covid-19, nas redes de ensino, independentemente dos níveis, etapas e modalidades. Com base na portaria citada e diante do cenário que o país estava vivendo, tanto os Conselhos Estaduais de Educação quanto os Conselhos Municipais de Educação emitiram pareceres com orientações para as instituições de ensino pertencentes aos seus respectivos sistemas sobre a 
reorganização do calendário escolar e uso de atividades não presenciais.

Buscando formas de atender ás atividades de ensino em todas as suas modalidades, níveis e etapas, uma vez que os casos de Covid19 em todos os continentes e no Brasil estavam em ascensão, o Governo Federal editou a Medida Provisória no 934, que trazia o estabelecimento de normas excepcionais para o ano letivo de 2020, tanto na educação básica quanto no ensino superior, como forma de enfrentamento da situação de emergência de saúde pública, conforme trata a Lei no 13.979, de 6 de fevereiro de $2020^{45}$.

Já a Portaria no 376, de 3 de abril de 2020, publicada pelo MEC, dispôs sobre as aulas nos cursos de educação profissional técnica de nível médio enquanto durar a situação da pandemia da Covid-19. Entretanto, de forma excepcional, ela autorizou que as instituições integrantes do sistema de ensino federal, quanto aos cursos de educação profissional técnica de nível médio em andamento, suspendessem as aulas presenciais ou substituíssem por atividades não presenciais por até 60 dias; caso houvesse necessidade, o MEC, em consonância com órgãos de saúde estaduais, municipais e distrital, as prorrogaria.

Para além do cancelamento das atividades presenciais, a portaria apresentou várias outras ações, cabendo destacar: criação do Comitê Operativo de Emergência (COE); implantação de sistema de monitoramento de casos de coronavírus nas instituições de ensino; destinação dos alimentos da merenda escolar diretamente aos pais ou responsáveis dos estudantes; disponibilização de cursos de formação de professores e profissionais da educação por meio da plataforma Ambiente Virtual de Aprendizagem do Ministério da Educação (AVAMEC); disponibilização de curso on-line para alfabetizadores

45 http://www.planalto.gov.br/ccivil_03/_ato2019-2022/2020/lei//13979.htm. Dispõe sobre as medidas para enfrentamento da emergência de saúde pública de importância internacional decorrente do coronavírus responsável pelo surto de 2019. 
dentro do programa Tempo de Aprender; concessão de bolsas da Coordenação de Aperfeiçoamento de Pessoal de Nível Superior (Capes) para estudos de prevenção e combate a pandemias, como o coronavírus; ampliação de recursos tecnológicos para educação a distância em universidades e institutos federais; e vagas em cursos de educação profissional e tecnológica na modalidade a distância.

Outro fator considerado na portaria refere-se à reorganização do calendário escolar e à possibilidade do cômputo de atividades não presenciais para fins de cumprimento da carga horária mínima anual. Para isso, o CNE publicou edital de chamamento de consulta pública sobre texto de referência do parecer que trata da reorganização dos calendários escolares e da realização de atividades pedagógicas não presenciais durante o período de pandemia da Covid-19.

Com a suspensão das aulas presenciais em todo o território nacional, os estados e municípios seguiram ritmos diferenciados, dependendo da extensão e intensidade da contaminação pela Covid19. A suspensão das aulas presenciais trouxe consigo uma série de agravantes difíceis de ser mensurados, pois causam, entre outros fatores, danos estruturais e sociais, sobretudo, para estudantes e famílias de baixa renda, como, por exemplo, abandono e aumento da evasão escolar, além de as condições de acesso ao mundo digital dos estudantes e de suas famílias terem se acentuado com o processo pandêmico no país. Tais fatores conduziram as instituições de ensino da educação básica de todo o país a pensar formas de (re)organizar o calendário escolar, para não causar perdas aos estudantes, minimizando a desigualdade de aprendizagem. Essa não foi uma tarefa fácil de ser resolvida, por envolver não só a comunidade acadêmica, mas também as famílias.

Para além da reorganização do calendário escolar, o MEC, com base no Parecer CNE/CP no 5/2020, propôs sugestões de atividades pedagógicas não presenciais para todos os níveis de ensino, como pode ser visto no Quadro 10.1. 
Quadro 10.1 - Possibilidades de atividades pedagógicas não presenciais para a Educação Infantil, Ensino Fundamental - Anos Iniciais e Ensino Fundamental - Anos Finais e Ensino Médio

\begin{tabular}{|c|c|}
\hline Educação Infantil & $\begin{array}{l}\text { Para crianças das creches (0 a } 3 \text { anos): } \\
\text { pais devem indicar atividades de estímulo às } \\
\text { crianças, leitura de textos pelos pais, } \\
\text { brincadeiras, jogos, músicas infantis. Para } \\
\text { auxiliar pais ou responsáveis que não têm } \\
\text { fluência na leitura, sugere-se que as escolas } \\
\text { ofereçam aos cuidadores algum tipo de } \\
\text { orientação concreta, como modelos de leitura } \\
\text { em voz alta em vídeo ou áudio, para engajar } \\
\text { as crianças pequenas nas atividades e garantir } \\
\text { a qualidade da leitura. } \\
\text { Crianças da pré-escola (4 e } 5 \text { anos): indicar } \\
\text { atividades de estímulo às crianças, leitura de } \\
\text { textos pelos pais ou responsáveis, desenho, } \\
\text { brincadeiras, jogos, músicas infantis e algumas } \\
\text { atividades em meios digitais, quando for } \\
\text { possível. A ênfase deve ser proporcionar } \\
\text { brincadeiras, conversas, jogos, desenhos, } \\
\text { entre outros, para os pais ou responsáveis } \\
\text { desenvolverem com as crianças. As escolas e } \\
\text { redes podem também orientar as famílias a } \\
\text { estimular e criar condições para que as } \\
\text { crianças sejam envolvidas nas atividades } \\
\text { rotineiras, transformando os momentos } \\
\text { cotidianos em espaços de interação e } \\
\text { aprendizagem. Além de fortalecer o vínculo, } \\
\text { esse tempo em que as crianças estão em casa } \\
\text { pode potencializar dimensões do } \\
\text { desenvolvimento infantil e trazer ganhos } \\
\text { cognitivos, afetivos e de sociabilidade. }\end{array}$ \\
\hline $\begin{array}{l}\text { Ensino } \\
\text { Fundamental - } \\
\text { Anos Iniciais }\end{array}$ & $\begin{array}{l}\checkmark \text { Aulas gravadas para televisão organizadas pela } \\
\text { escola ou rede de ensino de acordo com o } \\
\text { planejamento de aulas e conteúdos ou via } \\
\text { plataformas digitais de organização de } \\
\text { conteúdos. } \\
\checkmark \text { Sistema de avaliação realizado a distância sob } \\
\text { a orientação das redes, escolas e professores } \\
\text { e, quando possível, com a supervisão dos pais } \\
\text { acerca do aprendizado dos seus filhos. }\end{array}$ \\
\hline
\end{tabular}




\begin{tabular}{|c|c|}
\hline & $\begin{array}{l}\checkmark \text { Lista de atividades e exercícios, sequências } \\
\text { didáticas, trilhas de aprendizagem por fluxo de } \\
\text { complexidade relacionadas às habilidades e } \\
\text { aos objetos de aprendizagem. } \\
\checkmark \text { Orientações aos pais para realização de } \\
\text { atividades relacionadas aos objetivos de } \\
\text { aprendizagem e habilidades da proposta } \\
\text { curricular. } \\
\checkmark \text { Guias de orientação aos pais e estudantes } \\
\text { sobre a organização das rotinas diárias. } \\
\checkmark \text { Sugestões para que os pais realizem leituras } \\
\text { para seus filhos. } \\
\checkmark \text { Elaboração de materiais impressos compatíveis } \\
\text { com a idade da criança para realização de } \\
\text { atividades (leitura, desenhos, pintura, recorte, } \\
\text { dobradura, colagem, entre outros). } \\
\checkmark \text { Realização de atividades on-line síncronas, } \\
\text { regulares em relação aos objetos de } \\
\text { conhecimento, de acordo com a disponibilidade } \\
\text { tecnológica. } \\
\checkmark \text { Oferta de atividades on-line assíncronas } \\
\text { regulares em relação aos conteúdos, de acordo } \\
\text { com a disponibilidade tecnológica e } \\
\text { familiaridade do usuário. }\end{array}$ \\
\hline $\begin{array}{l}\text { Ensino } \\
\text { Fundamental - } \\
\text { Anos Finais e } \\
\text { Ensino Médio }\end{array}$ & $\begin{array}{l}\checkmark \text { Elaboração de sequências didáticas construídas } \\
\text { em consonância com as habilidades e } \\
\text { competências preconizadas por cada área de } \\
\text { conhecimento na BNCC. } \\
\checkmark \text { Utilização, quando possível, de horários de TV } \\
\text { aberta com programas educativos para } \\
\text { adolescentes e jovens. } \\
\checkmark \text { Distribuição de vídeos educativos de curta } \\
\text { duração, por meio de plataformas digitais, mas sem } \\
\text { a necessidade de conexão simultânea, seguidos de } \\
\text { atividades a ser realizadas com a supervisão dos } \\
\text { pais. } \\
\checkmark \text { Realização de atividades on-line síncronas de } \\
\text { acordo com a disponibilidade tecnológica. } \\
\checkmark \text { Oferta de atividades on-line assíncronas de } \\
\text { acordo com a disponibilidade tecnológica. } \\
\checkmark \text { Realização de testes on-line ou por meio de } \\
\text { material impresso, entregues ao final do período de } \\
\text { suspensão das aulas. }\end{array}$ \\
\hline
\end{tabular}




\begin{tabular}{|l|l|}
\hline & $\begin{array}{l}\checkmark \text { Utilização de mídias sociais de longo alcance } \\
\text { (WhatsApp, Facebook, Instagram etc.) para }\end{array}$ \\
estimular e orientar os estudos, desde que \\
observadas as idades mínimas para o uso de cada \\
uma dessas redes sociais.
\end{tabular}

Fonte: adaptado do Parecer CNE/CP no 5/2020.

Portanto, conforme o Parecer CNE/CP no 5/2020,

as orientações para realização de atividades pedagógicas não presenciais, para reorganização dos calendários escolares, neste momento, devem ser consideradas como sugestões. Nessa hora, a inovação e criatividade das redes, escolas, professores e estudantes podem apresentar soluções mais adequadas. Deve ser levado em consideração o atendimento dos objetivos de aprendizagem e o desenvolvimento das competências e habilidades a serem alcançados pelos estudantes em circunstâncias excepcionais provocadas pela pandemia.

Ocorre que a situação de excepcionalidade perdurou e adentrou o ano de 2021. Assim, o ano letivo de 2020 propiciou uma experiência inédita na história da humanidade e da educação formal, especialmente na educação básica. As normativas para uma situação tida como passageira foram construídas durante o ano letivo, ajustando-se a cada passo de avanço e persistência da pandemia, que ainda não teve fim.

Essa situação, mais longeva do que se imaginava inicialmente, afetou profundamente o fazer pedagógico nas escolas, o profissional professor, os estudantes e o processo de aprendizagem, como se pretende discutir adiante.

\section{A PANDEMIA DO NOVO CORONAVÍRUS E A ORGANIZAÇÃo ESCOLAR NO ESTADO DO PARANÁ}

Com as mudanças que a pandemia da Covid-19 trouxe para a sociedade atual, especialmente na forma de relacionamento para evitar que o vírus circulasse entre a população, uma das categorias 
profissionais mais afetadas foi a dos professores. $\mathrm{O}$ uso de tecnologias da informação e comunicação para realizar o trabalho pedagógico na educação básica exigiu que profissionais antes acostumados ao contato direto com seu público passassem a ter esse contato realizado de maneira remota, por meio de recursos com os quais não estavam habituados.

Nesse contexto, a educação - professores, equipes gestoras, Secretarias da Educação - precisou criar um sistema remoto para atender aos estudantes e dar continuidade ao ano letivo. $O$ relato a seguir tem como objetivo mostrar como se deram as ações realizadas pela Secretaria de Estado da Educação e do Esporte do Paraná (SEED$\mathrm{PR}$ ) ao longo do ano de 2020, no que diz respeito às normativas referentes ao ensino remoto emergencial.

O primeiro momento foi marcado pelo retorno das aulas após o recesso escolar, começando em 20 de março e indo até 6 de abril de 2020, com a oferta do ensino remoto pelas plataformas Aula Paraná, Google Classroom, aulas pela TV aberta e pelo YouTube. O segundo momento, entre maio e julho, foi marcado pela mudança na quantidade de atividades propostas aos estudantes, pois percebeu-se que a adesão deles foi baixa. Nesse período, ainda faltava orientação aos professores sobre a organização pedagógica na nova relação espaçotemporal junto aos estudantes.

O terceiro momento se deu logo após as férias de julho, quando houve orientação para que aulas fossem realizadas pela ferramenta de videochamada Meet. A partir de setembro de 2020, 0 que era uma sugestão de ferramenta pedagógica passou a ser procedimento obrigatório e o acesso ao Meet foi usado como registro da frequência do docente. O quarto momento, do fim do mês de novembro até o encerramento do ano letivo, em dezembro, foi marcado pela necessidade de resgatar alunos que não haviam participado das aulas remotas e/ou retirado as atividades impressas na escola. 


\section{O LONGO E INCERTO ANO LETIVO DE 2020}

Diante da constatação da pandemia e da necessidade de fechar as escolas, o estado do Paraná optou por decretar recesso escolar entre os dias 20 de março e 6 de abril de 2020, com o objetivo de organizar os próximos passos para que as atividades escolares pudessem ter prosseguimento. No entanto, os ajustes à nova realidade iniciaram-se mesmo antes do recesso, com o Decreto Estadual no 4.230, de 16 de março de 2020. Com essa normativa, o governo estadual adotou regime de urgência a ser implantado a partir do mês de abril.

Após o recesso, no mês de abril, iniciou-se o primeiro momento de organização do ensino na escola pública, com um plano que consistia em ofertar aulas remotas utilizando várias plataformas, como a TV aberta, o YouTube, aplicativos como o Aula Paraná e o Google Classroom. Os materiais didáticos utilizados e disponibilizados para os alunos foram os vídeos de aulas gravadas por professores que foram chamados especialmente para isso, acessadas via TV e YouTube por todas as escolas da rede. Para os alunos que não conseguissem assistir às aulas pela TV aberta ou acessá-las pelo canal do YouTube, foi criado material impresso denominado Trilhas de Aprendizagem, referente ao conteúdo abordado na aula gravada e transmitida pela TV aberta, em parceria com a RIC TV, conforme observado na imagem a seguir.

Imagem 10.1 - Canais 


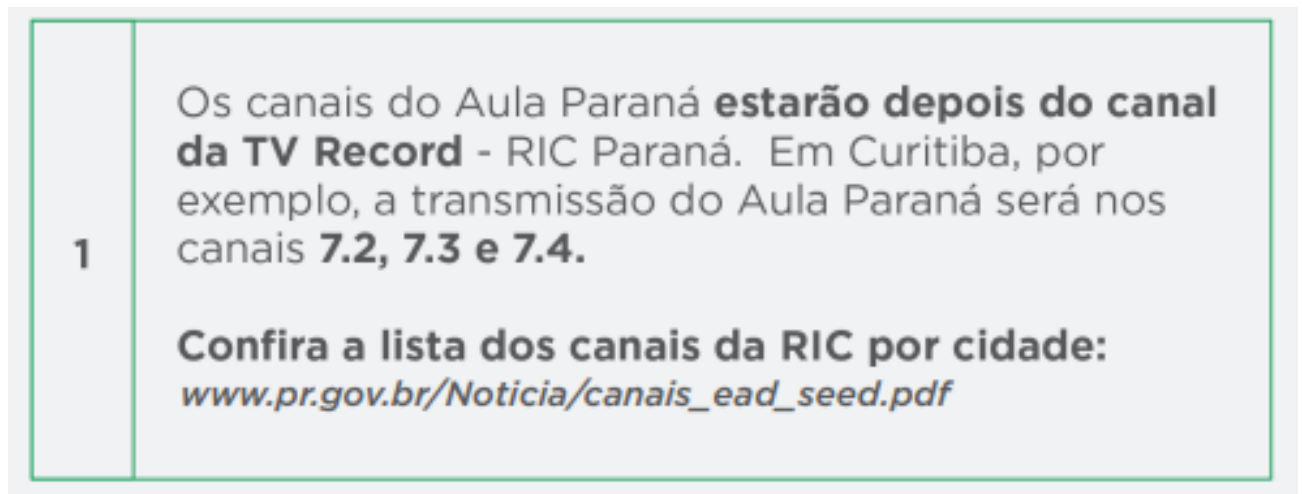

Fonte: SEED 2020.

Os vídeos das aulas gravadas também foram disponibilizados na sala virtual da turma, criada no Google Classroom.

Esse plano de ensino remoto emergencial foi posto em prática após o período de recesso mencionado, sem que fosse realizada uma discussão ou até mesmo orientação aos educadores sobre como seria a organização pedagógica, buscando, neste primeiro momento, tão somente disponibilizar algum tipo de conteúdo para que os estudantes não ficassem sem ter o que estudar.

A ideia era dar atendimento remoto aos alunos, mas com a mediação dos professores que atenderiam suas turmas nas salas de aula virtuais disponibilizadas no Google Classroom. Essa mediação consistia na troca de mensagens pelo Mural de forma pública ou por comentários particulares, além do uso de e-mail corporativo. O Google Classroom apresenta outras possibilidades de interação, como Meet, Hangout e ferramentas como o Drive e Google Forms, porém muitos professores e alunos não sabiam como utilizar esses recursos e não houve capacitação para tal.

Ressalta-se que os recursos ofertados na plataforma do governo do Paraná tinham uma configuração e uma dinâmica de uso diferente dos seus similares da Microsoft, gerando, assim, mais dificuldades e conflitos técnicos na sua utilização. Documentos produzidos em Word eram convertidos automaticamente em PDF quando postados no Google Classroom, o que dificultava a sua manipulação por parte dos alunos e professores. 
Definidas as ferramentas pelas quais se daria o ensino remoto emergencial, começou o segundo momento de acomodação do ano letivo, nos meses de maio a julho de 2020. Nesse período, o Google Classroom passou a ser a sala de aula virtual e as aulas remotas tornaram-se o principal canal de comunicação e interação entre professores e alunos, porém era a mantenedora que postava os vídeos, as atividades e os materiais das aulas na TV aberta.

Esse novo ambiente virtual, composto pelas plataformas digitais Aula Paraná, Google Classroom e TV aberta, permitia também acesso pelo celular e foi feita pela SEED-PR parceria tanto com o Google Education quanto com empresas de telefonia. Assim, dados móveis dos celulares foram disponibilizados de forma gratuita para que professores e estudantes pudessem acessar as plataformas digitais, o que se configurou como positivo, pois possibilitou o acesso dos alunos carentes e dos professores às plataformas citadas. Contudo, muitos deles não conseguiram utilizar o benefício por falta de informação ou mesmo por não possuir celulares que comportassem os aplicativos.

A falta de informações claras e de capacitação gerou dificuldades, pois muitos professores e estudantes não sabiam como ter a gratuidade de uso dos dados móveis nessa parceria para acessar os conteúdos do Aula Paraná. Também, alunos, pais e responsáveis ficaram confusos e muitas vezes recorriam aos professores e à direção das escolas, que nem sempre tinham informações suficientes para esclarecer.

Sobre o uso da plataforma Google Classroom e do Aula Paraná, a dificuldade era relativa à falta de conhecimento, pois a plataforma era nova para a maioria dos professores e as orientações feitas ao vivo, por técnicos do Google, nas lives via YouTube, acabavam deixando mais dúvidas do que esclarecimentos sobre o funcionamento. Mesmo professores que já estavam acostumados a outros ambientes virtuais 
de aprendizagem tiveram dificuldade no início na utilização das ferramentas do ambiente virtual ofertado pela mantenedora.

Além da dificuldade com os programas, havia a questão da organização do trabalho pedagógico: como adaptar os planos de aula para o ensino remoto emergencial? Não foi realizado um alinhamento de ações e tanto professores quanto equipes gestoras acabaram tendo de aceitar as normativas dadas pela SEED-PR, ou seja, o protagonismo docente acabou não ocorrendo.

Muitos alunos e professores, devido à dificuldade de interagir pelos canais oficiais (Aula Paraná, Google Classroom e e-mail corporativo), começaram a utilizar outros canais de comunicação. Mesmo estudantes mais velhos, do Ensino Médio, com maior familiaridade com a tecnologia tiveram dificuldades para acessar, realizar as atividades, anexar arquivos etc. Quanto às crianças do Ensino Fundamental, essas dificuldades também envolviam os pais e responsáveis, frequentemente sem conhecimento para auxiliar seus filhos, gerando frustração e críticas sobre o modelo adotado. Assim, redes sociais como Facebook e, principalmente, WhatsApp passaram a ser usadas, o que gerou alguns conflitos, pois isso fez com que muitos professores passassem a atender a alunos fora dos canais oficiais e fora de sua jornada de trabalho, causando desgaste físico e mental.

Pode-se considerar que os meses de maio, junho e julho foram de muita angústia e dificuldades técnicas para adaptação às aulas remotas. Foram recorrentes também as mudanças de orientação sobre a forma de atender aos alunos, com interpretações diferentes entre as escolas. Alguns professores utilizaram somente os conteúdos e materiais disponibilizados pela SEED-PR, enquanto outros postavam materiais próprios (aulas gravadas, resumos dos conteúdos e avaliações), o que gerou reclamações de alunos, pais e responsáveis.

Uma dificuldade específica emergiu da configuração do ensino remoto emergencial: como os sujeitos da educação deveriam se portar na nova realidade? Aos professores coube a reflexão sobre como 
desenvolver as atividades, como avaliar os alunos nesse momento, o que cobrar, como interagir. Os alunos, por sua vez, passaram a acessar a sala de aula virtual nos mais variados horários (até de madrugada) e, por não entenderem como funcionava o Mural da sala de aula virtual no Google Classroom (espaço onde eram feitas as interações entre professor e alunos), acabavam encaminhando dúvidas que já haviam sido respondidas, causando sobrecarga de trabalho para os professores.

O estresse causado pela mudança na rotina de trabalho e de estudos afetou tanto professores quanto alunos, que se sentiram desmotivados com o formato de ensino remoto emergencial. Além disso, os estudantes do Ensino Fundamental precisavam de apoio dos pais ou responsáveis para entender os conteúdos ou até mesmo acessar a plataforma digital. O uso da tecnologia era importante, mas, pelos relatos dos alunos, tanto do Ensino Fundamental quanto do Médio, observou-se que não conseguiam assistir às aulas porque $o$ celular não comportava o programa utilizado. Mesmo podendo acessar sem custo os dados móveis, alegavam que não tinham internet e que não conseguiam assistir às aulas e realizar as atividades. Destaca-se que essa realidade é de alunos da capital do Paraná (Curitiba), podendo ter sido ainda mais caótica e difícil em cidades do interior do estado, com menor infraestrutura e cobertura de internet.

Passado o recesso de julho, teve início o terceiro momento de organização do ano letivo. A mantenedora, notando a diminuição da participação dos alunos, passou a cobrar dos professores uma maior interação com eles para que se sentissem mais próximos, acolhidos, diminuindo a sensação de isolamento causada pela pandemia. Observa-se que, nessa situação, a mantenedora compreendeu a importância do vínculo professor-aluno.

A solução apontada pela mantenedora para motivar os alunos a participar das aulas remotas e, assim, aumentar os acessos às plataformas utilizadas seria a utilização de mais uma ferramenta para 
interação, o Google Meet ou simplesmente Meet. É preciso lembrar que os professores já atendiam aos alunos de forma remota pelo Google Classroom, corrigindo as atividades postadas e impressas e interagindo por meio do Mural da sala virtual, além dos profissionais que se propuseram a atender pelas redes sociais. Em função da pandemia e do trabalho dos professores no modelo remoto a quantidade de atividades passou a ser maior em função da adaptação do novo formato, bem como, a procura do professor por parte dos estudantes que em muitos momentos acabava extrapolando a carga horária diária do docente ((PEREIRA, SANTOS, MANENTI, 2020).

O Meet é uma ferramenta que possibilita a aula on-line, com o aluno e o professor interagindo em tempo real, de modo a tirar dúvidas, trocar ideias, cabendo ao professor motivar o aluno a realizar as atividades postadas no Google Classroom. Seu uso gerou, mais uma vez, uma crítica muito forte, pois, além da falta de capacitação para organizar a aula, havia sobrecarga de trabalho, visto a necessidade de atendimento das dúvidas pelo Mural, e-mail, redes sociais, além da correção dos trabalhos e atividades postados on-line e das atividades impressas dos alunos que, sem acesso à internet, entregavam nas escolas a cada 15 dias. Tudo isso ainda acumulava com o preenchimento do Registro de Classe On-Line (RCO), com as postagens obrigatórias no Mural para constar como presença para o professor, além de verificar outra ferramenta, chamada Power BI, para verificar os educandos que alegavam que estavam realizando as atividades, mas cujo acesso não ficava registrado no Google Classroom. Como as atividades diárias ficaram disponíveis durante o ano todo, com o aluno tendo a possibilidade de fazer todas até o último dia letivo de aula (18 de dezembro de 2020), isso exigia que o professor verificasse as aulas desde 6 de abril para conferir se ele tinha acessado ou não a atividade.

É importante mencionar a questão da exposição da imagem, tanto de professores quanto de alunos, o que trouxe muita contestação e recuo da mantenedora sobre a utilização do Meet. Mesmo que nos 
documentos oficiais a obrigatoriedade do uso do Meet não estivesse presente, os gestores escolares foram pressionados a cobrar dos seus professores o uso dessa ferramenta.

O fato é que, desde o início das aulas remotas até o final do ano letivo, professores, alunos, pais e equipe gestora sentiram-se apreensivos sobre o processo de ensino-aprendizagem, uma vez que o ensino remoto emergencial se mostrou desinteressante e desarticulado. Como a aprendizagem e a avaliação ficaram comprometidas pelo processo trucando e pela pouca efetividade das ferramentas tecnológicas ofertadas pela mantenedora, houve questionamento por parte da comunidade escolar sobre 0 aproveitamento do ano letivo

Nessa perspectiva, vale uma reflexão: o que deveria ser apreendido pelos estudantes, seus familiares e a comunidade em um ano atípico como foi 2020 ? Quais competências e habilidades deveriam ter sido trabalhadas pelas escolas nesse momento histórico? Infelizmente, essa reflexão não foi proposta para a sociedade, tampouco foi realizada pela escola. Assim, o que mais pesou para a sociedade e para o governo foram os dados estatísticos, os índices de frequência e aprovação e as notas obtidas pelos estudantes nesse caótico processo de construção de um ensino remoto emergencial.

A partir disso, definiu-se o quarto e último momento de acomodação do ano letivo - do final do mês de novembro até o encerramento das aulas, em dezembro -, quando intensificou-se a busca pelos alunos que não tinham acessado as atividades ofertadas ou o fizeram esporadicamente. Houve, naquelas semanas, uma forçatarefa das escolas para contatar esses estudantes, visando claramente a apenas melhorar os dados estatísticos da participação discente.

Para Sobrinho Junior e Moraes (2020) no final de 2020, ficaram cada vez mais claras as opiniões divergentes sobre as escolas fechadas, com prevalência para uma declarada contrariedade de grande parte da população. A sociedade parecia não reconhecer o 
trabalho dos professores e gestores no atendimento dos alunos no que se constituiu como ensino remoto emergencial. Naquele momento, algumas escolas, contrariando a orientação dos órgãos de saúde, passaram a permitir a presença de alunos, acessando as plataformas digitais dos computadores disponíveis no próprio estabelecimento de ensino. Professores se dispuseram a atendê-los presencialmente ou, em alguns casos, se sentiram obrigados a cumprir uma escala de atendimento. As atividades impressas, que deveriam respeitar duas semanas de quarentena, passaram a ser entregues aos professores sem observar esse período, com o risco de contaminação pelo vírus.

Houve, então, a orientação do CNE para que se observasse a excepcionalidade do momento, evitando a evasão e visando à retenção de alunos. Pode-se dizer que dessa forma, seguindo a orientação do $\mathrm{CNE}$, todos os estudantes da rede estadual de ensino do Paraná que, de alguma forma, realizaram quaisquer atividades, seja remota, seja impressa, por uma das plataformas digitais disponibilizadas ou pela TV aberta no ano de 2020 foram aprovados ${ }^{46}$.

Dessa forma encerrou-se o ano letivo de 2020, que pode ser resumido em muito esforço, muita energia despendida, muita frustração, cansaço e falta de reconhecimento social. Ficaram evidentes o despreparo da sociedade para lidar com a situação de exceção, a falta de valorização da escola pública, o não reconhecimento da importância do professor e o descompromisso e/ou falta de condições materiais e intelectuais das famílias para acompanhar a vida escolar de seus filhos. Permanece a dúvida sobre como será o futuro desse ensino remoto emergencial proposto para a educação pública do Paraná e do Brasil, uma vez que adentramos 2021 ainda em pandemia e sem vacina para todos. 


\section{FAMÍlIAS, ESTUDANTES E PROFESSORES: O PROCESSO EDUCACIONAL DURANTE A PANDEMIA}

Prosseguindo as reflexões realizadas até agora, é possível afirmar que as ações desenvolvidas pelas instâncias responsáveis pelos sistemas de ensino no Brasil, descritas anteriormente, repercutiram de formas diversas e complexas na vida real dos professores, estudantes e famílias. Tais repercussões configuraram-se em dificuldades significativas para que o processo educativo tivesse êxito nesse período de exceção da pandemia do novo coronavírus.

Para elencar algumas dessas dificuldades, optou-se por considerar a realidade do maior público da esfera educacional, qual seja, estudantes de escolas públicas e de classe social média-baixa e baixa. Serão apresentados alguns dos maiores empecilhos ao êxito educacional na pandemia, vividos pelas famílias, estudantes e professores, ao longo de 2020.

O primeiro problema, sem dúvida, foi a falta de equipamentos, como computadores e tablets, e falta de acesso à internet. Em 29 de abril de 2020, o Instituto Brasileiro de Geografia e Estatística (IBGE) publicou a Pesquisa Nacional por Amostra de Domicílio Contínua Tecnologia da Informação e Comunicação (PNAD Contínua - TIC). Os dados são referentes ao último trimestre de 2018 e mostraram que um em cada quatro brasileiros não tem acesso à internet (aproximadamente 46 milhões de pessoas) (IBGE, 2018), ou seja, apenas $75 \%$ da população brasileira tem acesso à internet e, portanto, ao ensino remoto. Segundo dados da pesquisa TIC Domicílios ${ }^{47}$ de 2019, entre os dispositivos mais utilizados para esse acesso, estão os smartphones e outros aparelhos móveis (99\%), seguidos por computadores (42\%) e TVs (37\%) (CETIC/BR, 2019).

\footnotetext{
47 Pesquisa realizada pelo Centro Regional para Desenvolvimento de Estudos sobre a Sociedade da Informação (Cetic-BR), vinculado ao Comitê Gestor da Internet no Brasil.
} 
Esses dados, porém, se alteram ao considerar as classes sociais. Os notebooks e tablets estão presentes nas casas das famílias mais ricas ( $90 \%$ têm notebook e $49 \%$, tablet). Já entre as camadas mais pobres da população, esses índices caem para 3\% e 4\%, respectivamente (IBGE, 2018). Diante desses quantitativos, pode-se afirmar que, na melhor das hipóteses, o ensino remoto no Brasil alcança $75 \%$ da população e, entre os mais pobres, via conexão por telefone celular com banda larga de qualidade questionável. Nas famílias com menos recursos, há, muitas vezes, apenas um aparelho celular para que adultos e crianças acessem a internet, o que limita ou quase impossibilita a realização das atividades educativas cotidianamente.

Um segundo problema que dificulta os estudos remotos nas famílias de baixa renda é o tamanho das casas em relação ao número de moradores e compartilhamento de cômodos. Dados obtidos pela PNAD mostram que, em 15,1\% dos domicílios em que há adultos e crianças, vivem seis ou mais pessoas. Em 40\%, há mais de três moradores por dormitório (IBGE, 2018). Sem um espaço adequado e um mínimo de silêncio e tranquilidade, as crianças não conseguem concentração para os estudos.

Configura-se um terceiro obstáculo ao processo de aprendizagem das crianças a falta de instrução dos familiares, acrescida do desconhecimento de estudantes e responsáveis sobre como usar as plataformas de comunicação a distância (Google Meet, Teams, Zoom). De um lado, a falta de instrução dos adultos, mais intensa nas classes menos letradas, impede que eles auxiliem as crianças nas tarefas e na compreensão dos conteúdos, uma vez que no ensino remoto a mediação do professor é menor. De outro lado, a inabilidade com as ferramentas de ensino remoto revelou que a geração nativa digital não é tão autônoma quanto se supunha, principalmente quando a finalidade de navegação são os estudos. Por fim, observou-se que muitos pais, em tom reclamatório, reivindicavam que não caberia a 
eles desempenhar o papel de professor, pois, de fato, não o são. Tomara tenham feito a reflexão de que ao professor também não cabe desempenhar o papel de pai/mãe e que, após a pandemia, deixem de cobrar essa atitude das escolas.

Todo esse contexto contribuiu para desenvolver a resistência dos estudantes para estabelecer uma rotina de estudos, que, sem suporte educacional em casa, começaram a sentir-se desligados da escola. Em algumas famílias, em que os pais/responsáveis também se submeteram ao trabalho remoto, todos os problemas mencionados até aqui - falta de equipamentos, acesso à internet, conhecimento das plataformas de comunicação a distância, falta de instrução para ajudar nas tarefas dos filhos etc. - foram potencializados, o que gerou cansaço extremo, esgotamento, tensões, conflitos e até aumento da violência doméstica.

O estresse familiar associa-se intimamente à incerteza/insegurança do futuro próximo, à possibilidade de adoecer e de vivenciar o adoecimento de um familiar/ente querido, ao medo de não conseguir acesso adequado à saúde, às notícias que não são promissoras nas mídias, aos problemas econômicos relacionados à perda do emprego e/ou à queda do rendimento familiar mensal. Soma-se a esses fatos o aumento do tempo de convívio com as crianças e os adolescentes, agora praticamente 24 horas, tanto pela necessidade de isolamento social como pelo fechamento de escolas, parques e áreas de lazer dos condomínios.

[...] Essa tensão experienciada e expressada pelos pais reflete-se nas crianças e nos adolescentes, que passam a adotar o mesmo comportamento: tensão, desmotivação e agressividade, que podem ser intensificadas pelo tempo excessivo em tela. Toda essa gama de fatores favorece um ambiente doméstico violento, que, associado ao distanciamento dos órgãos de proteção, do medo de perder o único provedor da família, de não conseguir sair de casa para, por exemplo, ficar na casa dos seus pais (avós das crianças), até pelo medo da ruptura do relacionamento, propicia assim a manutenção do pacto do silêncio dentro de casa, ficando todos vulneráveis a sofrer violências. (PLATT; GUEDERT; COELHO, 2021, p. 4).

Cabe aqui, ainda, um importante parêntese sobre um aspecto cultural que marca a educação dos filhos no Brasil, bem como o papel 
que a escola exerce na rede de proteção, desde a Lei no 8.069/1990, que dispõe sobre o Estatuto da Criança e do Adolescente.

\begin{abstract}
A violência familiar possui forte conotação histórico-cultural: pais que foram educados de forma violenta reproduzem essa forma de educar, recorrendo à violência física e psicológica, manifestada por surras, puxões de cabelo, palmadas, gritos e as mais diversas ameaças como forma de impor disciplina aos seus filhos.

Reconhece-se como primordial o papel protetor da escola, identificando na figura do professor muitas vezes o confidente, o profissional com um olhar atento aos alunos sob seus cuidados, aquele que poderá ser o acionador da rede de proteção e cuidados e garantir os direitos da criança e do adolescente. Entretanto, segundo a Organização das Nações Unidas para a Educação, a Ciência e a Cultura (Unesco), cerca de 1,5 bilhão de crianças e adolescentes em todo o mundo estão fora da escola por causa do fechamento das instituições de ensino como iniciativa para a contenção de casos da COVID-19. Assim sendo, as crianças deixam de contar com um espaço importante de manifestação e revelação da violência sofrida (PLATT; GUEDERT; COELHO, 2021, p. 4; 5).
\end{abstract}

Prosseguindo sobre as dificuldades de se efetivar o processo educacional durante a pandemia, destaca-se, da perspectiva dos professores, a falta de preparo para trabalhar com as plataformas digitais. As críticas à formação inicial são unânimes em apontar o fato de que poucos cursos de formação de docentes têm em seus currículos a preparação para uso de recursos digitais com fins educacionais.

No Brasil, apesar de a grande maioria dos professores (76\%) terem recentemente buscado formas para desenvolver ou aprimorar seus conhecimentos sobre o uso das tecnologias para auxiliar nas aulas, apenas $42 \%$ indica ter cursado alguma disciplina sobre o uso de tecnologias durante a graduação, e somente $22 \%$ participaram de algum curso de formação continuada sobre o uso de computadores e internet nas atividades de ensino. Consequentemente, $67 \%$ dos docentes alegam ter necessidade de aperfeiçoamento profissional para o uso pedagógico das tecnologias educacionais (TODOS PELA EDUCAÇÃO, Nota Técnica, 2020, p. 13).

Foi preciso viver repentinamente um momento de exceção para escancarar, de uma vez por todas, essa falha na formação dos professores no Brasil. Contudo, como esse tipo de déficit não se resolve num passe de mágica, o ano de 2020 foi uma dura travessia, repleta 
de dificuldades para operação dos meios digitais, que geraram muito sofrimento e comprometeram a qualidade pedagógica do trabalho docente.

\begin{abstract}
Cotidianamente, professoras e professores, principalmente em final de carreira, apresentam alguma dificuldade para lidar com o complexo aparato tecnológico disponível para o trabalho com plataformas de educação à distância e outros recursos digitais, algo que no contexto da pandemia se tornou uma necessidade. Trata-se de um universo que exige 0 estabelecimento de novas relações de comunicação que inclui, além da aquisição de um novo glossário de palavras e expressões - como, lives, aulas on line, classroom virtual, webconferência, chat, podcast, homeschooling, entre outros -, o desenvolvimento de competências para promoção de aprendizagem adequadas a esse novo ambiente (SOUZA, 2021, p. 07).
\end{abstract}

Urge formar professores mais bem preparados para a lida com ferramentas tecnológicas, especialmente as digitais, de modo que façam uso tranquilo dos recursos para aulas a distância ao vivo, dinâmicas e interativas.

Do ponto de vista econômico, cabe lembrar que os professores tiveram de arcar com os custos extras de luz e internet, pois a maioria das mantenedoras não forneceu ajuda nesse sentido. Assim,

[...] a responsabilidade pela transformação do espaço domiciliar em posto de trabalho permanente para desenvolvimento do ensino remoto coube exclusivamente aos docentes. Do mesmo modo, todos os custos relacionados às condições materiais do trabalho e infraestrutura física, como computador, câmera, microfone, impressora, internet, luz elétrica, mobiliário, entre outros, ficaram a cargo dos docentes. Além dessas despesas, houve a necessidade de manutenção desses equipamentos e do próprio manuseio de tecnologias e mídias (SOUZA, 2021, p. 06).

Além disso, assombrou os professores ao longo de 2020, especialmente os contratados sem estabilidade, o medo de perder 0 emprego ou de ser substituído por alguma solução tecnológica emergente. Por fim, não é demais lembrar também que, pelas estatísticas de gênero disponíveis, é possível afirmar que as professoras tiveram um acréscimo de horas de trabalho diário, 
acumulando o home office com os cuidados com a casa e os filhos, afinal a desigualdade de gênero ainda é uma realidade indiscutível no país.

\begin{abstract}
E além dos desafios até então observados nesse contexto excepcional de trabalho, dividi-lo em um espaço exclusivamente doméstico tornou ainda mais relevante a problematização das relações sociais de gênero, na medida em que as mulheres têm enfrentado o cotidiano de jornadas opressivas e exaustivas. [...] Assim, é preciso considerar que em segmentos como a educação básica no país, cerca de $80 \%$ do corpo docente é formado por mulheres (Carvalho, 2018), o que aponta para a necessidade de um aprofundamento dos estudos que contemplem as discussões de gênero, assim como as de raça e classe social. [...] Certamente, mulheres enfrentam a divisão desigual de tarefas domésticas, especialmente as casadas e com filhos. Segundo Vieira, Garcia e Maciel (2020), durante o isolamento social, em regime de home office, o trabalho doméstico aumentou na medida em que há mais pessoas passando mais tempo em casa. No ambiente do lar, na maioria das vezes, a presença dos homens em casa não significa cooperação ou distribuição simétrica das tarefas, mas sim o aumento da sobrecarga de trabalho feminino (SOUZA, 2021, p. 7; 8).
\end{abstract}

\title{
A ESCOLA APÓS A PANDEMIA
}

Com o objetivo de ponderar os argumentos dos entusiastas com as tecnologias da comunicação e informação, que falam na necessidade de a escola pós-pandemia se reinventar, incorporando o ensino remoto à parte de sua carga horária, é preciso refletir sobre dois aspectos: qual é a natureza da escola básica e como os dados socioeconômicos implicam, entre outras coisas, o acesso de professores e estudantes aos recursos tecnológicos necessários para essa mudança.

Antes de abordar a natureza ou o principal papel social da escola básica, é preciso lembrar que as aulas remotas não configuram educação a distância. São mera solução emergencial para um momento de exceção. Por sinal, é bom retomar: a educação a distância tem legislação e orientação pedagógica regulamentada, enquanto o ensino remoto para a educação básica teve, tão somente, alguns 
direcionamentos criados e recriados no processo de implementação, mas não tem sequer projeto pedagógico.

Dito isso, deixa-se claro que a discussão de como vai ficar a escola básica depois da pandemia não passa, simplesmente, pela defesa da incorporação das aulas remotas ao currículo, mas, sim, pela crítica do que foi essa travessia e pelo debate, nunca esgotado, sobre o papel da escola. Então, qual é o papel da escola atualmente na sociedade? Quais reflexões a pandemia possibilitou sobre o potencial da escola como espaço privilegiado para emancipação social?

A escola tem sido, historicamente, um espaço em que o projeto de futuro da sociedade se expressa, especialmente pela configuração do currículo prescrito e pelas concepções de ensino e aprendizagem validadas para cada momento histórico. É, portanto, território de luta de classes, onde o destino traçado para as diferentes classes sociais se configura na hegemonia das práticas e dos conteúdos de ensino. Talvez por essa função, a escola tenha se mantido como uma instituição social validada e considerada necessária, destarte todas as críticas que pairam sobre ela há muito tempo.

Diante dessa primeira reflexão e dos dados estatísticos apresentados neste texto, é possível afirmar que a pandemia trouxe à tona, de forma clara e inquestionável, as desigualdades sociais, além do fato de que as aulas remotas deixaram de fora da escola uma significativa parcela dos estudantes, em especial os mais carentes. Então, se para alguns, após a pandemia, as escolas poderiam fazer uso mais constante dos recursos tecnológicos para comunicação e informação, antes será preciso resolver o problema da inclusão digital, que não é simples e está enraizado na estrutura social e econômica do país. Caso contrário, será desrespeitado o direito constitucional de igualdade de condições para acesso e permanência na educação formal, conforme preconiza a Constituição Federal de 1988. 
Art. 205. A educação, direito de todos e dever do Estado e da família, será promovida e incentivada com a colaboração da sociedade, visando ao pleno desenvolvimento da pessoa, seu preparo para o exercício da cidadania e sua qualificação para o trabalho.

Art. 206. O ensino será ministrado com base nos seguintes princípios:

I - igualdade de condições para o acesso e permanência na escola;

II - liberdade de aprender, ensinar, pesquisar e divulgar o pensamento, a arte e o saber;

III - pluralismo de ideias e de concepções pedagógicas, e coexistência de instituições públicas e privadas de ensino;

IV - gratuidade do ensino público em estabelecimentos oficiais [...] (BRASIL, CF, 1988).

Outro aspecto importante a ser lembrado refere-se ao fato de que, desde o contexto do processo de redemocratização do Brasil, nos anos 1980, o currículo escolar teve momentos mais alinhados às teorias críticas da educação, em busca de uma formação cidadã e da diminuição das desigualdades, e outros momentos (mais longos) de alinhamento com linhas pedagógicas neoliberais, que acirram as diferenças e prejudicam os mais carentes, aqueles que não têm núcleo familiar de apoio nem repertório cultural consistente no ponto de partida. Destaca-se que, durante esses altos e baixos, os debates curriculares sempre trouxeram à tona o papel da escola como espaço de socialização do conhecimento validado pela sociedade, espaço de preparo para compreensão social mais ampla, para inserção no mundo do trabalho, para vivência cultural e aprendizagem de enfrentamentos diversos. Por esse aspecto, no pós-pandemia defende-se a ideia de que a escola deverá chamar a comunidade para discutir todo o processo ocorrido. Que se organizem palestras bem fundamentadas, que dados oficiais quantitativos sejam apresentados às famílias e aos estudantes, de modo que as definições sobre como será a escola de um futuro próximo envolvam todos os sujeitos interessados.

É importante não esquecer também que, além do papel de instituição formativa, desde o início dos anos 1990, a escola passou a fazer parte da rede de proteção de crianças e adolescentes, desempenhando esse papel junto a casos de abuso, maus-tratos, 
exclusão etc. Por isso, o acompanhamento cotidiano que professores, equipe pedagógica e gestão escolar fazem do desempenho intelectual, social e emocional dos estudantes requer um contato presencial contínuo, uma vez que a distância fica muito mais difícil perceber - e denunciar - os diversos tipos de agressão sofridos por alguns deles.

Diante dessas reflexões, espera-se que após a pandemia, incluindo a educação a distância em parte da carga horária escolar ou não, haja o fortalecimento da escola reflexiva, espaço de acolhimento e orientação, de ensino e de crítica social, em direção à formação de gerações cada vez mais críticas e participativas socialmente.

\section{REFERÊNCIAS}

MINISTÉRIO DA EDUCAÇÃO. PORTARIA No 343, DE 17 DE MARÇO DE 2020. http://www.planalto.gov.br/CCIVIL_03/Portaria/PRT/Portaria\%20n\%C2\%BA\%2034 3-20-mec.htm

MINISTÉRIO DA EDUCAÇÃO. Parecer CNE/CP no 5/2020.

https://normativasconselhos.mec.gov.br/normativa/pdf/CNE_PAR_CNECPN52020.p df

BRASIL, República Federativa. Constituição da República Federativa do Brasil. 1988.

Centro Regional de Estudos para o Desenvolvimento da Sociedade da Informação Cetic. Pesquisa TIC Educação 2018. Disponível em: https://cetic.br/pesquisa/educacao/indicadores/ Acesso em: 16/01/2021.

Instituto Brasileiro de Geografia e Estatística (IBGE). PNAD Contínua TIC 2018. Disponível em: https://agenciadenoticias.ibge.gov.br/agencia-detalhe-demidia. html ?view=mediaibge\&catid=2103\&id=3674 Acesso em: 16/01/2021.

Instituto Nacional de Estudos e Pesquisas Educacionais Anísio Teixeira (INEP). Microdados da Prova Brasil - Questionário dos Professores, 2017. Disponível em : http://portal.inep.gov.br/educacao-basica/saeb/instrumentos-de-avaliacao. Acessado em: 16/01/2021.

BRASIL. Lei Federal n. 8069, de 13 de julho de 1990. ECA _ Estatuto da Criança e do Adolescente.

SOBRINHO JUNIOR, João Ferreira; MORAES, Cristina de Cássia Pereira de. A CoVID19 e os reflexos sociais do fechamento das escolas. Dialogia, São Paulo, n. 36, p. 128-148, set./dez. 2020. https://periodicos.uninove.br/dialogia/article/download/18249/8708

SOUZA, Kátia R. et al. Trabalho remoto, saúde docente e greve virtual em cenário de pandemia. Trabalho, Educação e Saúde, v. 19, 2021, e00309141. DOI: 10.1590/1981-7746-sol00309.

PLATT, Vanessa Borges; GUEDERT, Jucélia Maria; COELHO, Elza Berger Salema. Violência contra crianças e adolescentes e alerta em tempos de pandemia. Revista paulista de pediatria, São Paulo, v. 39, 2021 . Disponível em:http://www.scielo.br/scielo.php?script=sci_arttext\&pid=S010305822021000100434\&Ing=en\&nrm=iso> Acessado em 21 Jan. 2021.

TODOS PELA EDUCAÇÃO. Nota Técnica: Ensino a distância na Educação Básica frente à Pandemia da Covid19. Abril, 2020. Disponível em: . https://todospelaeducacao.org.br/wordpress/wp- 
content/uploads/securepdfs/2021/01/ensino-a-distancia.pdf.

$16 / 01 / 2021$. 


\section{POSFÁCIO}

\section{CONSIDERAÇÕES FINAIS DA OBRA}

Os capítulos apresentados nesta obra tiveram o objetivo de proporcionar aos leitores alguns elementos para o debate acerca de diversos temas que dialogam diretamente com a área de geociências. Tais reflexões mostram-se cada vez mais necessárias no mundo acadêmico, em função do atual momento pandêmico vivido no Brasil e no mundo.

Englobando vários temas, os artigos refletem sobre como a pandemia no Brasil alterou a rotina dos profissionais da educação e seus efeitos não só no trabalho docente, mas na saúde dos professores. Outros dialogam entre si ao mostrar para os leitores as práticas de ensino em um cenário pós-pandemia e os impactos no trabalho docente e na aprendizagem dos alunos.

Para além do campo educacional, fatores relacionados aos aspectos urbanos e à participação popular na justiça espacial foram afetados pela pandemia. Entre tais aspectos, destacam-se: a necessidade de reestruturação e ressignificação dos espaços, principalmente públicos, com as suas formas de uso e apropriação; e a importância da adoção de práticas e comportamentos para uma urbanização inclusiva e sustentável, com planejamento e gestão de assentamentos humanos participativos, de modo que o setor do turismo possa se restabelecer com políticas que valorizem o local e, sobretudo, a natureza. Ainda dessa perspectiva política e social, foram analisadas a manifestação socioespacial da pandemia e as relações entre as nações no que se refere ao acesso à vacina e procedimentos 
de controle da doença. Todas essas análises indicam a necessidade de luta por uma sociedade justa, por mais humanidade entre os seres humanos.

A respeito das relações sociedade-natureza, discutiram-se aspectos diversos, como a reflexão sobre o contexto da pandemia e a alteração da luminosidade do planeta, remetendo a uma reflexão sobre a artificialização da vida na Terra e a emergência de novas condições ambientais que podem trazer doenças desconhecidas ou para as quais ainda não temos tratamento nem prevenção. Nessa perspectiva, foi proposto também o debate sobre a necessidade de outras práticas ambientais, com mais cuidados com o consumo e o descarte, numa orientação metodológica sobre compostagem caseira, possibilitando o engajamento individual num problema que é coletivo, planetário.

Assim, este livro buscou despertar diversos olhares sobre o tema da pandemia do novo coronavírus, convidando o leitor a refletir sobre: a complexidade e as consequências do modo de vida, de produção e consumo predominante no planeta; a fragilidade das formas e das práticas sociais - entre elas, as educacionais - diante do necessário inesperado e urgente isolamento social; as relações que se estabelecem entre as classes, os povos e as nações em situações de saúde pública mundial; a triste e inquestionável desconexão entre humanidade e natureza, que agrava problemas ambientais numa dimensão impossível de mensurar.

Os autores esperam que a leitura desperte outros enfoques e questionamentos no sentido de aprofundar reflexões e ampliar o debate sobre o tema. 